\title{
Fraternity and Governance in Fifteenth-Century English Literature
}

by

Danielle Renee Taylor

A thesis submitted to the Faculty of Graduate and Postdoctoral Affairs in partial fulfillment of the requirements for the degree of

Doctor of Philosophy

in

English Language and Literature

Carleton University

Ottawa, Ontario

(C) 2021, Danielle Renee Taylor 


\begin{abstract}
In this dissertation, I explore the intersection between fraternity and governance within fifteenth-century English literature, arguing that the familial relationships in these texts go beyond the interpersonal and are used by the authors to think through questions of both self-governance and the governing of the polity. Drawing on methods used by historians of emotions, such as Barbara Rosenwein, I trace the usage of terms indicating brotherhood across a variety of genres (romances, plays, sermons, letters, and wills), and consider the depictions of brothers' behaviours, motivations, and speeches in these texts. This analysis reveals that governance and fraternity are linked in several unique but complementary manners in fifteenth-century England, and that authors utilize fraternal relationships to demonstrate a wide variety of good and bad governance of self and others. In each chapter, I trace the discourses of fraternity within a unique conceptual framework: Scriptural foundations, Classical foundations, the Rise of Arthur, the Fall of Arthur, and the Rise of the Gentry. The variety and prominence of discourses of fraternity within the genres and texts studied here demonstrate the power of brotherhood in the cultural imaginary of the period. The authors of these texts all grapple with the doubleedged sword of fraternity, exploring how characters navigate the complexities of brotherhood. The authors use fraternity as a tool to explore how interpersonal relationships can have a larger influence on the polity around them, proving that fraternity, much like authority, can be used and abused for personal gain, often to the detriment of others.
\end{abstract}




\section{Acknowledgements}

This project has been made possibly through the love, support, guidance, and encouragement of all the wonderful people in my life. I cannot thank everyone individually who has made this journey not only possible but enjoyable, but please know that I appreciate you all. The past six years have been some of the best of my life, and I am forever grateful for those in my life who helped make that happen.

To Dr. Siobhain Bly Calkin: Your guidance and wisdom have been invaluable to me over the last six years. Whether it be through copious feedback on my work or through our meetings which could last hours, your advice consistently improved my work and encouraged me to push my own limits and have allowed me to emerge a stronger scholar for it. It has been a pleasure and a privilege to be your student and I will be forever grateful for the investment you made in me and my work.

To Dr. Robin Norris and Dr. Andrew Wallace: Thank you for investing your time in me and my work. Your contributions have helped shaped this project, and I am grateful for your insightful comments and feedback. I would also like to thank Dr. Marc Saurette and Dr. Megan Leitch for agreeing to be the external readers on this project, and for taking the time to engage with my work.

To the faculty, staff, and students in the English department: Thank you being such a supportive and encouraging community. Thank you, Dr. Brian Johnson, Dr. Julie Murray, and Dr. Travis DeCook. As the Graduate Supervisors you offered your guidance, encouragement, and expertise during my years at Carleton. I am also beyond grateful for the tireless work of the graduate administrators who have been invaluable in my success. 
Thank you, priya kumar and Lana Keon, for helping me navigate graduate school and for being my cheerleaders when I really needed it.

To my family: I want to thank you all, especially my parents, Kirk and Sandra, who encouraged me to go after my dreams and to believe in myself, who taught me the value of hard work, and who instilled a love of learning in me well before I entered school. I do not have the words to express how much your love and support means to me. It is crazy to think that all those early nights begging for just one more book (or three) would lead to my completing a dissertation in medieval literature. To my brother, Jonathan: I know you will always be there to support me in whatever I do. Thank you for being the best brother anyone could ask for.

To my friends: You have made my doctoral degree some of the best years of my life and I am beyond grateful for your support. Thank you for all the days sitting in the library working together with plenty of breaks for laughter and conversation. Thank you for the vacations, both the weekends in Montreal and the trip to Disneyworld to experience magic when I needed it the most. From boardgame nights to baking days, from countryside drives to dinners out, your support and company have kept me sane and happy throughout the stress of graduate school. Thank you for reading over my work, for offering your insights and suggestions, which have all helped make this project that much stronger. Your encouragement and companionship have helped me every step of the way. 


\section{Table of Contents}

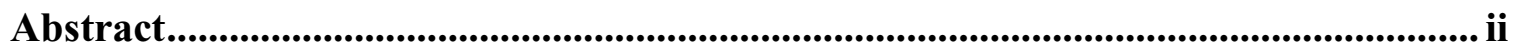

Acknowledgements .............................................................................................................................. iii

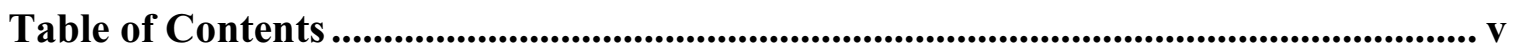

Introduction......................................................................................................................... 7

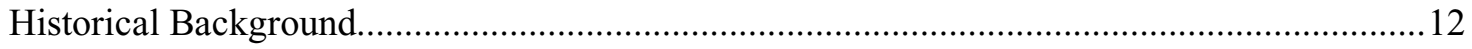

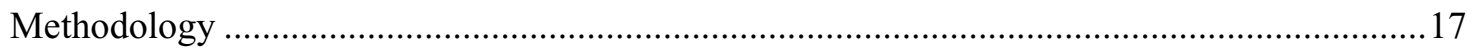

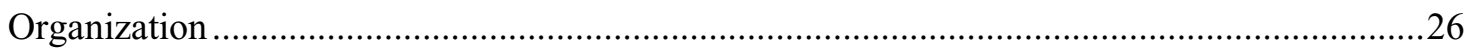

Chapter One: Cain and Abel: Scriptural Origins .....................................................34

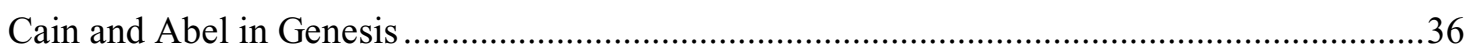

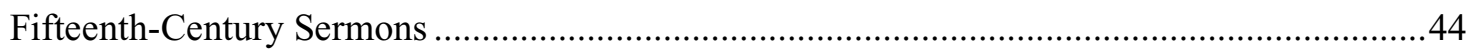

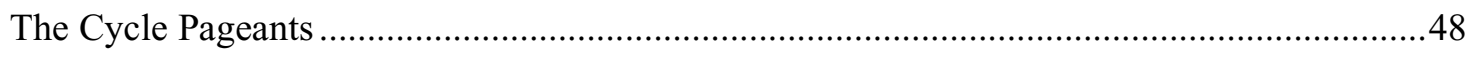

Edward IV and the Duke of Clarence and Conclusions .........................................................

Chapter Two: Siege of Thebes: Classical Origins ……….................................................. 75

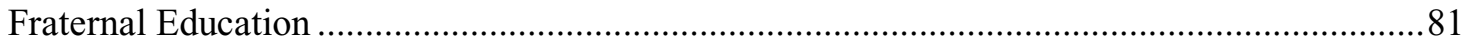

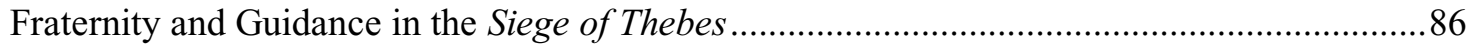

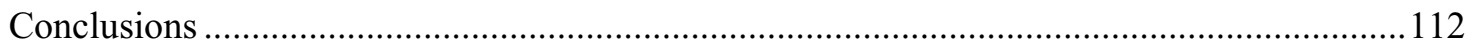

Chapter Three: The Prose Merlin: The Rise of Arthur............................................... 117

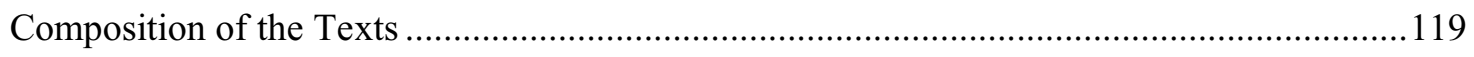

Necessary Fraternity and Claiming a Kingdom ...................................................................126

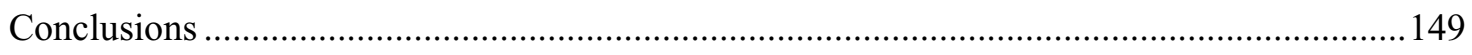

Chapter Four: Le Morte Darthur: The Fall of Arthur................................................... 152

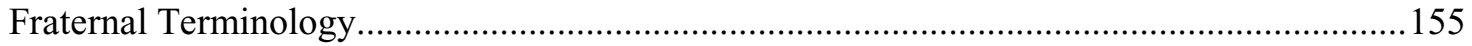

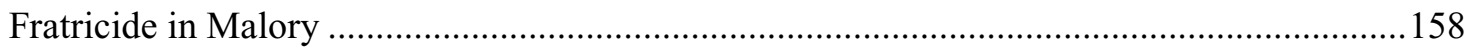




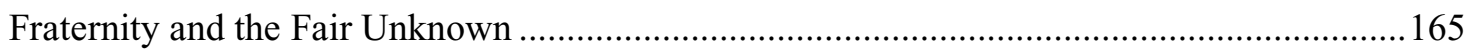

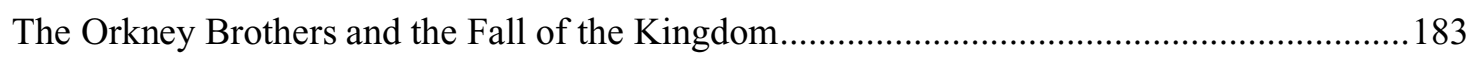

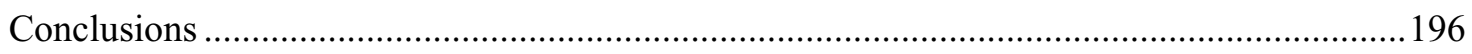

Chapter Five: The Tale of Gamelyn: The Rise of the Gentry ................................ 200

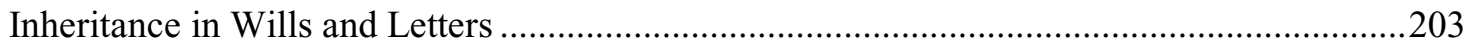

Inheritance and the $(\mathrm{Ab})$ use of Fraternal Terms in Gamelyn .................................................210

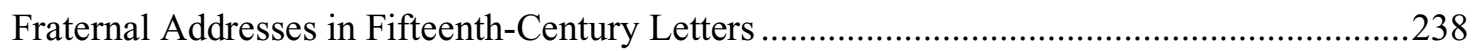

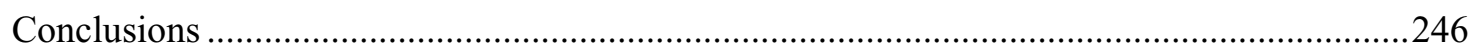

Conclusion: "Vnder a knotte bounde of broperhede" .......................................... 249

Bibliography ........................................................................................................................... 253 


\section{Introduction}

From the clergy to the guilds, from knights to actual kin, fraternity was a common framework for social, political, religious, and business relationships within fifteenthcentury England. In this dissertation, I examine how fifteenth-century authors and audiences in England engaged with texts and performances that navigate the connection between fraternity and governance. From self-governance to the governance of entire kingdoms, these texts grapple with how displays of fraternity, both good and bad, often reflect the governing capabilities of the characters. Within the following chapters, I establish that monarchs, aristocratic leaders, and powerful men were often depicted as brothers within texts and that we can judge their efficacy in those positions through their performances of fraternity, and vice-versa. I also demonstrate that authors explore how fraternity, as an inescapable bond, can limit a character's ability to govern both himself and others well. Good and bad governance and good and bad fraternity are linked in several unique but complementary manners across the fifteenth century, and my analyses of different texts from this period highlight this connection as one which was important and intriguing to the authors and audiences of the time. Fraternity, a relationship so valued that Christian monasteries, orders of knighthood, and merchant guilds all used it as a model to describe their own comraderies, is also a site for potentially dangerous rivalry. Throughout my dissertation, I demonstrate how some late medieval authors use this fraught relationship to explore how characters also handle their own governance or positions of power. I argue that in studying how these authors present fraternity, we gain a new and deeper understanding of how these texts present methods through which characters can reform themselves, either through or despite fraternity. 
Within this dissertation, fraternity refers to the bond shared between two or more men which is meant to indicate the expectation of mutual love and affection within the relationship. Though, as I demonstrate, many authors in the fifteenth century grapple with the problems which arise when these emotions are absent between men who are meant to call one another "brother." For the purposes of this dissertation, I focus mainly on consanguine fraternity of brothers born to the same parents. I do, however, include examples of brothers-in-law whose relationship is presented similarly to consanguine fraternity and harbours the same expectations and obligations associated with consanguine brothers. These brothers, who are connected within a fraternity based upon their shared lineage, are supposedly examples of an ideal homo-social bond, as terms such as "brother" and "fraternity" are utilized by non-related men to establish the importance and nature of their bond with others, such as those who live within a monastic fraternity, of the brotherhood of knights. The bonds which exist between brothers are meant to represent one of the most fundamental and ideal relationships men can have.

I argue that based upon the expectation that fraternity is a relationship founded upon mutual affection and loyalty, the authors studied in the following chapters present fraternity as a bond which demands specific emotional responses when the bond is evoked. However, I also argue that by examining moments in which affection and loyalty are notably absent in the relationship of brothers, many of the authors within this dissertation also demonstrate that fraternity is inherently contradictory. Several of the authors investigate the possibility that brotherhood can be based upon jealousy, hatred, and rivalry, rather than affection, love, and loyalty. Within this dissertation, I trace how fraternal terms of address and identification are utilized to either evoke specific emotional 
responses or to signal the significance of the absence of such emotions. The authors studied in this dissertation utilize both the expectation of affection and loyalty amongst brothers as well as the evidence of jealousy and rivalry to explore questions of various forms of governance and self-control. Fraternity and governance are inherently linked in the texts included in this project.

By examining the connection between these two concepts across a variety of genres, I demonstrate that these topics and concerns were an ongoing and widespread consideration and were engaged with throughout the literature of period. The texts studied in this dissertation rely upon a belief that their audiences would understand, appreciate, and expect powerful emotional ties to inform or influence the interactions between brothers and their individual behaviours. Authors, therefore, use the acceptance or denial of fraternity to examine cultural norms and expectations of brotherly relationships. I argue that in the texts presented here, the authors grapple with the doubleedged sword of fraternity, exploring how characters navigate the complexities of a relationship that, on the one hand, represents the closest of allies but, on the other hand, creates intense rivalry when it comes to the family resources available, such as land. Fraternity, both good and ill, was a powerful source of influence in fifteenth-century England.

Familial relationships in these texts go beyond the interpersonal and are used by the authors to think through questions of both the individual and the polity. A character's behaviour and attitude towards his brother become a representation of his regulation of self and the regulation of the larger polity. Fraternity becomes a tool through which the authors grapple with questions of self-governance as well as the governance of others and 
land. This is not to suggest that this dissertation is only about kings or lords. Rather, these figures are the best examples to represent governance, as readers and audiences would easily recognize such figures as having positions of power. By examining how fraternity is presented across various genres, we gain key insights into how medieval authors believed fraternity and governance to be interconnected. Through a careful consideration of the manners in which these various authors utilize fraternal relationships to demonstrate good or bad governance, we find a crucial familial lens to discover more about how self-improvement might have been conceived in the fifteenth century.

One of the main goals of this dissertation is to challenge traditional silos which have dominated medieval literary studies in the past. The dissertation builds upon current trends in the field of medieval literary studies by putting new texts into conversation to elucidate a broader understanding of the cultural norms and societal expectations of brothers in fifteenth-century England. Recent scholarship which has sought to break down some traditionally held silos include publications by Carolyn Larrington, Megan Leitch and Rachel Moss. ${ }^{1}$ Larrington, studying sibling relationships, and Moss, studying fatherhood, both examine familial relationships across several texts in medieval literature. Larrington studies literature from England, France, Iceland, and Germany. Moss studies late medieval letters in tandem with Middle English romances. Leitch's work, focused on treason, examines texts across several genres, including the writings of Lydgate and Malory. All three scholars demonstrate the benefit of breaking silos to gain a better

\footnotetext{
${ }^{1}$ Carolyn Larrington, Brothers and Sisters in Medieval European Literature (York: York Medieval Press, 2015); Megan Leitch, Romancing Treason: The Literature of the Wars of the Roses (Oxford: Oxford University Press, 2015); and Rachel E. Moss, Fatherhood and its Representation in Middle English Texts (Cambridge: D. S. Brewer, 2013).
} 
understanding of concepts across genres within the medieval period. In this dissertation, I focus on medieval English texts, and put romances into conversation with the works of Lydgate and Malory, as well as plays, sermons, letters, and wills from the fifteenth century to gain a deeper understanding of fraternity in late medieval England. By examining the genre of romance in tandem with plays, sermons, wills, and letters, we gain a better insight into the values and anxieties associated with fraternity and governance in the period which captured the cultural imagination of authors. This dissertation demonstrates that rather than a characteristic of a genre, the connection of fraternity and governance, both of the self and of the polity, was a common, albeit complex, anxiety which permeated the culture, society, and politics of fifteenth-century England.

In this dissertation, I also examine affect and emotion, a recent area explored by other scholars including Holly A. Crocker, Glenn D. Burger, and Sarah McNamer. ${ }^{2}$ There has also been a recent publication of a collection of articles dedicated to the study of emotion in Arthurian literature, Emotions in Medieval Arthurian Literature: Body, Mind, Voice. ${ }^{3}$ These works recognize the need for further study of emotions in the medieval period. However, I differ from these works in my focus on family and the expression of fraternal emotions. In this affective familial concentration, my work resembles that of Larrington and Moss, but I focus exclusively on expression of emotion between male

\footnotetext{
2 Burger and Crocker, eds, Medieval Affect, Feeling, and Emotion (Cambridge: Cambridge University Press, 2019); and Sarah McNamer, Affective Meditation and the Invention of Medieval Compassion (Philadelphia: University of Pennsylvania Press, 2010).

${ }^{3}$ Frank Brandsma, Carolyne Larrington, and Corinne Saunders, eds, Emotions in Medieval Arthurian Literature: Body, Mind, Voice (Cambridge: D. S. Brewer, 2015).
} 
siblings and therefore on constructions of masculinity related to fraternity. ${ }^{4}$ Building

upon the current interest on sibling studies in the field, I illuminate how medieval authors represented fraternal emotions between consanguine brothers, and how those emotions could be used and manipulated. The dissertation presents new insight into the prominence of interpersonal familial relationships, specifically consanguine brotherhood, within the fifteenth-century cultural imagination. Rather than focusing on knighthood or other associational fraternity, I examine how the language of consanguine relationships is utilized by late medieval authors to examine issues of governance, tying interpersonal relationships and feuds to the large polity of the kingdom at a time when the rule of the kingdom was perhaps at its most precarious.

\section{Historical Background}

From a historical standpoint, the fifteenth century in England appears to have been rife with wars and battles, with international war with France in the first half of the century and a series of conflicts constituting a civil war in the second half. The Hundred

\footnotetext{
${ }^{4}$ For examples of recent interest in the study of siblings see Leonore Davidoff, Thicker than Water: Siblings and Their Relations 1780-1920 (Oxford: Oxford University Press, 2012); Christopher H. Johnson and David Warren Sabean, eds., Sibling Relations and the Transformations of European Kinship 1300-1900 (Oxford and New York: 2011); Agnès Blandeau, "Les liens adelphiques dans quelques textes du Moyen Age: "ce surgissement des violences au sein des alliances,"” in Frères et sœurs: Les liens adelphiques dans l'Occident antique et médiéval. Actes du colloque de Limoges, 21 et 22 septembre 2006, eds Sophie Cassagnes-Brouquet and Martine Yvernault, Histoires de famille. La parenté au Moyen Age 8, 229-236 (Turnhout: Brepols, 2007); Angela Ittel and Aiden Sisler, Siblings in Adolescence : Emerging Individuals, Lasting Bonds (Hove, East Sussex: Psychology Press, Taylor \& Francis Group, 2015); Naomi Whit, and Claire Hughes, Why Siblings Matter: The Role of Brother and Sister Relationships in Development and WellBeing Abingdon (Oxon, NY: Routledge, 2019); Florian Mazel, “'Frères Ennemis'. Compétition Intrafamiliale et Intervention Pontificale dans les Successions Princières à I'âge Grégorien (Espace Français)," in Coopétition: Rivaliser, coopérer dans les sociétés du haut Moyen Age (500-1100), eds. Régine Le Jan, Geneviève Bührer-Thierry, and Stefano Gasparri, 255-267 (Turnhout: Brepols, 2018), Haut Moyen Age, 31.
} 
Years War (1337 to 1453) was an ongoing conflict between England and France that ended in defeat during the reign of Henry VI (1449-53). The Wars of the Roses (14501509) was a series of civil wars and battles waged between the houses of York and Lancaster. Michael A. Hicks summarizes the major events of the Wars of the Roses as follows:

There were three regional revolts, in 1450, 1489 and 1497; a host of private feuds, murders, ambushes, skirmishes and sieges; thirteen fullscale battles, including four in 1461, 1471, 1485 and 1487 that were decisive; at least ten coup d'état and attempted coups; fifteen invasions, including the four in 1460, 1470, 1471 and 1485 that succeeded; five usurpations, in 1461, 1470, 1471, 1483, and 1485; five kings - Henry VI, Edward IV, Edward V, Richard III and Henry VII - the first two of whom actually reigned twice; seven reigns; and fives changes of dynasty in 1461, $1470,1471,1483$, and $1485 .^{5}$

The Wars of the Roses were an ongoing collection of events in which two powerful and influential houses struggled continually for control of the crown. Fraternal and familial relationships were an inherent part of the wars, as they provided the ideological foundations upon which various rulers made their claims to power. As a period marked by the above events, fifteenth-century England would have naturally been filled with questions about what constituted fraternal loyalty and good governance, and how often those two concepts were at odds with one another. Throughout this dissertation, I argue

\footnotetext{
${ }^{5}$ Michael A. Hicks, The Wars of the Roses (New Haven: Yale University Press, 2010), 3.
} 
that fraternity, and the obligations associated with it, was one lens through which the authors of the period engaged with those questions.

The connection between fraternity and governance during these two distinct conflicts highlights the likelihood that these concepts would have been on the mind of fifteenth-century authors. During the height of the Hundred Years War, for example, the ability of brothers to govern together became a concern for the English people. Henry VI was eight months old when his father died in 1422, leaving him as the infant heir to the throne of England. His uncle, Humphrey, Duke of Gloucester, "claimed the regency under his brother's will" but his ambitious claims were mitigated by parliament and the Great Council, and he was awarded the "titles of Protector and Defender of the Realm and Chief Councillor."6 John, Duke of Bedford, brother of Humphrey, became the regent of France, acting on the behalf of his nephew in foreign affairs. These two brothers were in many ways governing the kingdom jointly. Brothers and governance were key interlocking issues throughout the fifteenth century in England, and it is no surprise that authors of the time explored the many issues which might arise in relation to this connection. $^{7}$

The link between brothers and governance can also be seen in the coronation of Edward IV, as recounted in the Chronicle of John Warkworth. Warkworth highlights the fact that "at the coronacyone of the forseyd Edwarde, he created and made dukes his two brythir, the eldere George Duke of Clarence, and his yongere brothir Richard Duke of

\footnotetext{
${ }^{6}$ J. R. Lander, Conflict and Stability in Fifteenth-Century England, $3^{\text {rd }}$ edition (London: Hutchinson \& Co Ltd, 1969, 1977), 60.

${ }^{7}$ Anxiety over the ability of brothers to co-rule will be explored specifically in Chapter Two.
} 
Gloucetre." 8 There are several other key positions which Edward appointed that are recounted in the chronicle, but those of his brothers are the first. However, during this time, brothers did not necessarily remain allies, as was the case with George, Duke of Clarence, who sided with his father-in-law, the Earl of Warwick, and rebelled against his brother, Edward IV (1469). An attempt was made in 1470 to have Clarence crowned king. When this attempt was unsuccessful, Warwick and Clarence, after fleeing to France, helped restore Henry VI to the throne, albeit briefly (October 1470 - May 1471), making Clarence the next heir. ${ }^{9}$ Edward IV was seemingly further betrayed by his second brother, Richard, Duke of Gloucester, who, after Edward's death, took the throne as Richard III when it rightfully should have passed to Edward's son. These events, and the others now categorized under the label of the Wars of the Roses, spanned the entire second half of the fifteenth century, and it is unlikely that any author writing in the period would have been unaware of them, though the events would have been understood as singular events rather than one long war, as it is categorized today.

Edward's brothers were not the only important figures at key moments in the ongoing conflicts. The rebellion led by the Earl of Warwick was, at least in part, motivated when "the Kynge put oute of the Chauceler-schepp the Bysshope of Excetre, brother to the Erle of Warwyke, and made the Bysshoppe of Bathe Chaunceler of Englonde. ${ }^{10}$ Evidence of the fact that fraternity was connected to the governance of the kingdom is also present in Edward IV's response to the rebellions against him. After the

\footnotetext{
${ }^{8}$ The Chronicle of Warkworth, in Three Chronicles of the Reign of Edward IV, ed. Keith Dockray (Gloucester: Alan Sutton Publishing, 1988), 23.

9 The feud between Edward and Clarence will be further considered in Chapter One.

10 Ibid., 25.
} 
Warwick rebellion was quelled, Edward sent for Warwick's brother George Neville, Archbishop of York, under the false pretense of inviting the man to join him in hunting: "the Kynge send a gentylman to the seide Archebisshoppe, and commaundyd him to come to Wyndsoure to hyme; and asone as he came he was arested and apeched of hye treysone" after which Edward took and distributed all of the goods of the Archbishop "for the sayd Archebisshoppe hade be Chaunselere of Englond many dayes, and he and his brotheres had the reule of the lande, and hade gaderyde grete rychesse many yeres." 11 George Neville was arrested in part because of his fraternal relationship with Warwick, and in part because the king took issue with his position of governance. Once again, a connection between brothers and governance was evidently a concern in significant historical events of the period. Powerful and important fraternal relationships were not limited to the political realm; they structured clerical realms of power and governance as well. Fraternity and governance were continually interlocked in ways which had consequences for larger polities beyond the interpersonal relationship of the brothers in question.

Many of the authors I study in this dissertation composed their works within the context of either the Hundred Years War or the Wars of Roses, when the political atmosphere of England was fraught with questions concerning feuding families and the governance of the kingdom. This is not to suggest that daily life in fifteenth-century England was riddled with wars and battles. Indeed, as Hicks himself states, "only occasionally and only briefly was normal life disrupted by political crisis." ${ }^{12}$ Rather, what

\footnotetext{
11 Ibid., 46-48.

12 Michael Hicks, English Political Culture in the Fifteenth Century (London: Routledge, 2002), 1.
} 
I argue here is that authors in the period identified a connection between fraternity and governance and used this connection to interrogate questions of good and bad governance. The obligations of fraternity and characters' willingness to adhere to or reject those obligations became a means by which to examine what it meant to govern either self or kingdom well.

\section{Methodology}

The main methodology that has helped inform my examination of the following texts is the history of emotions. The history of emotions is a field which seeks to explore how emotions have been both experienced and expressed in different historical, geographical, and linguistic periods. The field traces how our understanding of emotions has changed over time while also striving to fully understand how people in history actually felt. I focus on the emotional bonds which were expected to be present between brothers in late medieval England, as represented in the works of the authors I have included in this study. My work builds upon a movement in medieval studies which began in the 1980s and 90s when scholars such as Stephen D. White, Paul Hyams, and Daniel Lord Smail "took on such topics as affect and honour, anger and lordship, rancor and hatred in legal discourse."13 However, it is the work of Barbara Rosenwein which has become foundational for the current study of the history of emotions. Her work on emotional communities, which will be discussed more thoroughly shortly, is pivotal to any examination of the role of emotions in the medieval period. ${ }^{14}$ Piroska Nagy and

\footnotetext{
${ }^{13}$ Glenn D. Burger and Holly A. Crocker, Introduction to Medieval Affect, Feeling, and Emotion, 6. 14 Barbara Rosenwein, Emotional Communities in the Early Middle Ages (Ithaca and London: Cornell University Press, 2007).
} 
Damien Boquet have also been instrumental to the growth and direction of this relevantly new field. Their work argues against the idea of emotions as either universal or unchanging and traces the history of emotions in the medieval area, proposing a "cultural history of affectivity" in the western medieval world. ${ }^{15}$ As mentioned above, scholars such as McNamer, Burger, and Crocker have helped shape my approach to the study of emotions within medieval literature, as well as my understanding of the history of the field of emotion studies. I utilize the history of emotions to examine how late medieval authors articulate, explore, and utilize the expectations of emotional bonds between brothers. I argue that through a careful study of how these authors conceive of fraternity, we gain insight into how the expectation of emotional connection between brothers was, on the one hand, not always a reflection of reality and, on the other hand, something which could be manipulated.

One of the main issues that scholars of the history of emotions face is providing a meaning of the term "emotion," as it does not have a universally accepted definition. The question of "what are emotions" has been debated and discussed across several disciplines such as history, sociology, and even economics. ${ }^{16}$ Meridee L. Bailey defines emotions as "states of mind that touched the lives of individuals but which were also felt, expressed, and discussed at a community level" and suggests that "[m]oral standards and virtues can be thought about as responses which have been motivated by emotional states

\footnotetext{
15 Damien Boquet and Piroska Nagy, Medieval Sensibilities: A History of Emotions in the Middle Ages, trans. Robert Shaw (Cambridge: Polity, 2018).

${ }^{16}$ See, for example of this last discipline: Klaus Wälde and Agnes Moors, "Current Emotion Research in Economics," Emotion Review 9 no. 3 (July 2017): 271-8.
} 
related to fear and anxiety." 17 Jonathan Turner suggests that the definition of emotions is difficult to capture because "emotions operate at many different levels of reality biological and neurological, behavioral, cultural, structural, and situational." 18 In spite of these various definitions and categories, for the sake of clarity, I have chosen to follow Jonas Liliequist who, in his introduction to A History of Emotions, 1200-1800, uses "emotion" as "a catch-all term for what were conceptualized as passions, affects and sentiments by contemporaries." 19 The focus of this project is not an attempt to define, once and for all, the term "emotion" but rather to present the way in which fifteenthcentury authors used fraternity and the expectations associated with it to evoke, create, or criticize emotions and behaviours reflective of the societal values and norms of the period.

Through the exploration of how fraternal language is employed to evoke deliberate emotions and to attempt to force desirable behaviour, I demonstrate a key argument made by historians of emotions, namely, that emotions are both socially constructed and controlled. The value of individual emotions and the resulting emotional responses is based upon the society in which they are functioning, and these values and expectations can, and do, change over time. Burger and Crocker highlight this pivotal role of the field in identifying the socially contingent value of emotion:

\footnotetext{
17 Merridee L. Bailey, "Anxieties with Political and Social Order in Fifteenth-Century England," in Authority, Gender and Emotions in Late Medieval and Early Modern England, ed. Susan Broomhall (Basingstoke: Palgrave Macmillan), 85.

18 Jonathan Turner, "The Sociology of Emotions: Basic Theoretical Arguments," Emotion Review 1 no. 4 (October 2009): 314.

19 Jonas Liliequist, Introduction to A History of Emotions, 1200-1800, ed. Jonas Liliquist (London and Brookfield, Vermond: Pickering \& Chatto, 2012), 1.
} 
Perhaps most fundamentally, recognizing that emotions have histories allows us to begin to understand how emotions are not biological, coming from inside, as early modern theories of the passions or some modern biological theories might suggest, but historically contingent, arising out of a set of particular cultural and linguistic practices. ${ }^{20}$

By examining how emotions function and are evoked in the medieval texts I study, I demonstrate the way in which fifteenth-century authors viewed these emotions as fundamental, but also as socially constructed. The fact that one can learn to be a better brother, as I argue in Chapter Two, is evidence that these authors at some level viewed emotions as something which could be learned and reformed.

As such, my dissertation answers a call for further study and consideration raised by Jan. E. Strets, who argues that "[b]eyond the general idea that culture sets up expectations regarding what feelings should be experiences and expressed in situations, much remains unspecified. For example, greater specificity is needed regarding the actual emotion beliefs and norms that are contained within a culture." ${ }^{21}$ My work also addresses a concern raised by Burger and Crocker, who suggest that there has been an understandable focus on affective piety within medieval studies utilizing the history of emotions, but that this focus "has tended to narrow what we expect the focus of medieval studies of affect and emotion to be. As a result, we have only begun to tap the rich offerings of medieval representations." 22 Using the history of emotions to study late medieval fraternity allows for an examination of one such representation. Through this

\footnotetext{
${ }^{20}$ Burger and Crocker, 7.

21 Jan E. Stets, "Future Directions in the Sociology of Emotions," Emotion Review 2, no. 3 (July 2010): 265.

22 Burger and Crocker, 12.
} 
methodology, I demonstrate how ideas surrounding fraternity, based upon the expected emotions associated with such relationships, were used to examine broader social and political concerns.

The methodology used in my dissertation aligns particularly with the work of Peter and Carol Stearns, who propose the term "emotionology" for the study of emotions, ${ }^{23}$ of William Reddy, who coined the term "emotives," 24 and of Barbara Rosenwein, who examines what she has called "emotional communities" particularly in the medieval world. ${ }^{25}$ These three terms and the concepts behind them helped inform my own understanding of the history of emotions, and aided in my conceptualization of the discourses of fraternity present in fifteenth-century English literature. While I do not necessarily use these terms throughout the dissertation, and often simply use "emotion" for the sake of clarity, my understanding of what "emotions" are is heavily influenced by work of these scholars.

Peter and Carol Stearns argue that "[d]espite continued dispute over the appropriate definition of emotions, a substantial consensus exists that emotions are not simply biological reactions but also involve an interplay between body and mind." 26 They identify "emotionology" as " a useful term with which to distinguish the collective emotional standards of a society from the emotional experiences of individuals and

\footnotetext{
23 Peter N. Stearns and Carol Z Stearns, "Emotionology: Clarifying the History of Emotions and Emotional Standards," The American Historical Review, 90, no. 4 (October, 1985): 813-36.

${ }^{24}$ William Reddy, The Navigation of Feeling: A Framework for the History of Emotions (Cambridge: Cambridge University Press, 2001), ix.

${ }^{25}$ Rosenwein, Emotional Communities, 3. See also, Barbara Rosenwein, Generations of Feeling: A History of Emotions, 600-1700 (Cambridge: Cambridge University Press, 2016).

${ }^{26}$ Stearns, 834.
} 
groups." ${ }^{27}$ As they explain, "[e]motionology includes behaviour, such as courtship, that reflects and is meant to enforce social norms." ${ }^{28}$ I utilize this concept in my dissertation to examine the way in which authors depicted behaviours that they believed, or wished to believe, reflected cultural norms associated with both fraternity and the practices of good governance.

Reddy's idea of the "emotive" is also particularly useful for my examination of late medieval fraternity. Reddy defines "emotives" as:

A type of speech act different from both performative and constative utterances, which both describes (like constative utterances) and changes (like performatives) the world, because emotional expression has an exploratory and a self-altering effect on the activated through material of emotion. ${ }^{29}$

I argue that fraternal language, including terms of address, function as "emotives" in the texts studied in this dissertation. These "utterances," as Reddy labels them, describe the nature of the relationship between the characters while simultaneously evoking the expectation of those feelings. Calling someone brother is meant to be akin to acting as a brother. Using fraternal terms of address is, in some ways, performing the act of brotherly affection. Reddy also claims that emotions are "largely (but not entirely) learned." 30 My work takes this theory as a working methodology to explore how behaviour towards one's brother is expected to rely upon the emotional ties one is supposed to have towards

\footnotetext{
27 Ibid., 813.

28 Ibid., 825.

${ }^{29}$ Reddy, The Navigation of Feeling, 128.

30 Ibid., xi.
} 
another brother. Whether or not this theory is applicable to real world emotions is irrelevant for my purposes here, as I argue not that men in the fifteenth century experienced these types of constraints on their emotions, but rather that the authors of the period construct and depict performances of brotherhood through their ideology of fraternity.

Rosenwein's influence on the history of emotions as a field cannot be understated and "arguably it is the paradigmatic work of Barbara H. Rosenwein that has had the stronger and widest influence inside and outside medieval studies." 31 Thus, it is perhaps only natural that her work has contributed to the formation of my own understanding of the connection between medieval literature and the history of emotions. I utilize her concept of "emotional communities" to help formulate the boundaries of this project. Rosenwein describes "emotional communities" as "groups in which people adhere to the same norms of emotional expression and value - or devalue - the same or related emotions." 32 I argue that the authors in the texts and documents studied in this dissertation are operating under the expectation or desire for such a cohesive community. They rely upon expectations surrounding fraternal relationships for how brothers are meant to behave and feel towards one another to critique the characters' virtues and their ability to govern themselves and others. As Rosenwein argues, "[m]ore than one emotional community may exist - indeed normally does exist - contemporaneously, and these communities may change over time." 33 Rosenwein suggests that "emotional communities are in some ways what Foucault called a common 'discourse': shared

\footnotetext{
${ }^{31}$ Burger and Crocker, 6.

32 Rosenwein, Emotional Communities, 2.

33 Ibid..
} 
vocabularies and ways of thinking that have a controlling function, a disciplining function" and "are similar as well to Bourdieu's notion of 'habitus': internalized norms that determine how we think and act." ${ }^{34}$ I demonstrate that the ideologies surrounding notions of fraternity are employed by the various authors studied to create these "emotional communities," "discourse," and "habitus." Fraternity is created in each text as a unifying force which dictates how a character should act. Rosenwein does argue that "[e]motional communities are not constituted by one or two emotions but rather by constellations - or sets - of emotions, ${ }^{35}$ and my work, while focused on the expectations of brothers, does not argue against this claim. My argument is that through the exploration of the texts presented here we can witness how fraternity is, or at least is believed to be, one unifying force within fifteenth-century English society. The authors rely upon the existence of an emotional community in which the same values and expectations of fraternity are present.

My dissertation also follows Rosenwein in her endeavour to pay close attention to the actual terminology used in the sources and documents of the period. It is through understanding which terms are applied, both how and why, that we are better able to understand how emotions worked in the medieval period. Rosenwein views vocabulary as essential to any study of a community's emotions: "Because emotions are inchoate until they are given names, emotional vocabularies are exceptionally important for the ways in which people understand, express, and indeed 'feel' their emotions." ${ }^{36}$ As Rosenwein also argues, emotional communities can be seen as "textual communities,"

\footnotetext{
34 Ibid., 25.

35 Ibid., 26.

${ }^{36}$ Generations of Feeling, 4.
} 
suggesting that "with their very vocabulary, texts offer exemplars of emotions belittled and valorized." "37 The terminology and vocabulary used within the texts studied are key to understanding how these authors understood and manipulated the emotions of the characters, as well as the readers, as "words are mainly what the researcher must work with." 38 Throughout her work, Rosenwein traces what she terms "snapshots" of emotional communities, partly through the counting of "emotion words." 39 She also provides visual tables, such as the "Partial Latin Emotion Word List and Approximate English Equivalents," which outline emotion words utilized in different periods. ${ }^{40}$ I pay similar close attention to the language of fraternity that is employed by the various authors studied in this dissertation. I not only identify and quantify fraternal terms used in the texts studied, but also examine how they are invoked. I trace when the word brother is used as a descriptor and when it is used as a term of endearment and address, meant to evoke or reinforce bonds of brotherhood. This careful examination allows me to demonstrate that such terms were used and manipulated deliberately by authors in their explorations of the obligations and expectations of fraternity, and how such expectations might have consequences which reach beyond the interpersonal relationships and into the wider social, cultural, and political atmospheres and seats of power in the fifteenth century.

Using the ideas presented in the theories outlined above, I maintain throughout my dissertation that late medieval authors conceive of emotion as something which can

\footnotetext{
37 Emotional Communities, 25.

38 Generations of Feeling, 5.

${ }^{39}$ Emotional Communities, 30.

40 Ibid., 52.
} 
be learned, as something which influences and is influenced by the world around them, as something which includes shared values within their respective communities, and as something articulated, which can be traced through the medieval terminology used and the contextualization of such terms. Whether using the theoretical ideas from "emotionology," "emotives," or "emotional communities," I argue that the term "brother" is often used in place of such "emotives" to represent or demand specific emotional responses, particularly those associated with ideas of affection and loyalty, which align with the understanding of the "emotional communities" in which the characters operate. The expectations raised by these interpersonal relationships are used to examine broader social concerns in a period in which governance was unstable and constantly at risk of changing. Fraternity, for these authors, becomes a tool through which they examine questions of self-governance and self-improvement as well as raise concerns over the morality and competence of those who have the power to govern over the larger polity.

\section{Organization}

This dissertation is divided into five main chapters, each examining different aspects of the connection between governance and fraternity. In each chapter, I examine not only different texts, different genres, and different brothers, but also different conceptual understandings of fraternity. I begin by examining the biblical origins of fraternity and fratricide (Chapter One), then proceed to the inherited concept of fratricide from classical literature (Chapter Two), the role of fraternity in both the rise and fall of Arthurian society (Chapters Three and Four), and the social anxiety felt by the gentry class when fraternity and inheritance conflict with one another (Chapter Five). Each 
chapter, each conceptual framework for thinking through questions of fraternity, works together to form a more cohesive picture of how fifteenth-century English authors understood what brotherhood really meant.

My exploration of how fraternity and governance were interconnected in the minds of fifteenth-century authors begins in Chapter One with consideration of their depiction of what would have been considered the first incident of fratricide in the Christian mythos: the murder of Abel by his brother Cain. Beginning with these biblical origins of brotherhood, I examine how fraternal language is used to motivate expectations of behaviour or to criticize the conduct of those who, like Cain, allow themselves to be ruled by jealousy and anger. Utilizing Cain's behaviour as a brother, the story of Abel's murder becomes a way to demonstrate the broader consequences of lack of selfgovernance.

Within the chapter, I examine the story of the brothers Cain and Abel in Genesis, sermons, and late medieval pageant plays, which were performed in several cities across England around the Feast of Corpus Christi. My analysis highlights how both sermons and plays in the fifteenth century utilize Cain's behaviour and emotional outburst to demonstrate the importance of self-governance over our emotions and feelings. In terms of the pageants, I examine the language of the four main cycle pageants: Chester, NTown, Towneley, and York. My analysis focuses on the first three of these plays, as the York Cycle's "Cain and Abel" is incomplete. I argue that both the sermons and the pageants use the figure of Cain and his fratricidal murder of Abel as a warning to fifteenth-centuries audiences of the consequences of poor self-governance. This chapter, Chapter Two, and Chapter Five all examine issues that arise when the very nature of 
fraternity appears to be inherently contradictory, with brothers existing as both allies and rivals simultaneously. ${ }^{41}$ In the case of Cain and Abel, the competition between them, whether real or imagined by Cain, is enough to overcome feelings of loyalty or emotional ties, meaning that in the Christian world, fratricide is actually older than brotherly love. Thus, in a religion based in part upon love for one's fellow Christian, the idea of brotherly love is a learned and adopted behaviour rather than inherent within the bond itself.

Chapter Two examines a medieval representation of the foundational classical depiction of fraternity and fratricide. In this chapter, I explore John Lydgate's Siege of Thebes, a retelling of the ancient Greek story of the brothers Eteocles and Polyneices (named Polymyte within the Siege) and how their refusal to rule Thebes together paved the way for the destruction and fall of the entire city. The chapter examines the ways in which Lydgate represents their feuding as correlated to their competence as rulers and explores how the double fratricide of these brothers becomes the culmination of the failed fraternity between them. Rather than just self-governance, this chapter focuses on how the failed fraternity between the characters is reflected in their ability to rule as kings. I argue that the Siege examines larger political consequences when brothers in power fight. For the most part, in Lydgate's text, a good brother is a good leader, and a poor brother is a poor leader.

\footnotetext{
41 Stephen Bank and Michael Kahn note this paradoxical nature of sibling relationships, suggesting that "loyalty is a major theme or dimension of sibling relationships" as is "rivalry, conflict, and competition." Bank and Kahn, "Intense Sibling Loyalties," in Sibling Relationships: Their Nature and Significance Across the Lifespan, eds. Michael Lamb and Brian Sutton-Smith (Hillsdale, NJ and London: Psychology Press, 1982), 51.
} 
The chapter also considers the way in which Lydgate's concept of fraternity, and of its obligations and expectations, reflects ideas about fraternity in the monastic world in which he was educated and in which he participated. I consider how the values Lydgate assigns to good fraternity, particularly learning and education, align with the foundational text of his order: The Rule of St. Benedict. I argue that Lydgate's notion of fraternity is inherently tied to governance because of his understanding of the ideals and practices of monastic communities, and of the fact that there the behaviour of men as brothers and leaders would have been linked together naturally. Both self-governance and positions of formal governance are, at least partly, judged in tandem with one another, a fact reflected in Lydgate's presentation of the behaviour and reputation of the brother figures within the Siege.

In the next two chapters, I investigate the connection of fraternity and governance in fifteenth-century English adaptions of Arthurian literature. Chapter Three examines the connection of brothers and governance in two adaptations of thirteenth-century French texts focused on the history of Merlin: The Prose Merlin and Henry Lovelich's verse Merlin, both of which were composed around the mid-fifteenth century. In this chapter, I trace the importance of fraternity and brothers in the establishment of Arthur as a legitimate and powerful king. My analysis focuses on three groups of brothers: Uther and Pendragon, Ban and Bors, and the Orkney brothers. In these adaptations, brothers become necessary for Arthur's success in founding his kingdom. Throughout these texts, groups of brothers become instrumental in Arthur's early years, particularly regarding his struggles to overcome the opposition to his right to rule. This chapter focuses on the Rise of Arthur, particularly in its English adaptations in the later medieval period. While 
drawing upon earlier sources, particularly those from France, the fifteenth-century English Arthurian texts adapt the stories to examine contemporary values and anxieties, and fraternity is represented as a key element of the success of Arthur's ability to establish himself as a powerful and rightful ruler.

In Chapter Four, I turn my attention to role of fraternity in the Fall of Arthur. Whereas Chapter Three considered Arthur's beginnings, Chapter Four focuses on how fraternity, seen as necessary by the Merlin author, is problematically connected to the fall of Arthur's kingdom in Sir Thomas Malory's Le Morte Darthur. I examine this shift through a study of how the obligations of brotherhood are represented as inescapable in the Morte. I argue that Malory, as opposed to the author of the Prose Merlin, emphasizes the devastating consequences that arise when fraternity is upheld as one of the most important interpersonal relationships, particularly when those who adhere to this notion are in positions of power themselves or are close to those who govern the kingdom. I begin with an examination of the character of Balin who, through his inability to govern his own behaviour and emotions, takes part in events which lead to the tragic double fratricide of himself and his brother. I then focus on the Orkney brothers, particularly on Gawain and Gareth and their attempts to overcome excessive obligations of fraternity, and how their inability to do so devastates the society in which they live. I examine how these brothers, and the emotional ties between them, or the expected ties between them, play an integral role in the downfall of the kingdom. Whereas fraternity helps establish Arthur's realm in the Merlin texts, here it plays a major role in the destruction of Arthur's kingdom. 
In Chapters Three and Four, I seek to further highlight the perceived roles of consanguine brothers in Arthurian literature and to examine how consanguine fraternity appears integral in these English adaptations of the Arthurian story. Part of my efforts here are to further break the silo which has existed around Malory's Le Morte Darthur, a text which, partly because of its scope and length, has generally been studied in isolation from its contemporary English analogues..$^{42}$ By putting Malory into conversation with not only other Arthurian texts but also the other genres studied in this dissertation, a deeper sense of how fifteenth-century authors represented and manipulated fraternity within the Arthurian field emerges. Studying the emotional communities of consanguine brothers in the Arthurian world also shifts the focus away from the emotional communities of knighthood or brothers-in-arms, which has been a dominant theme in Arthurian scholarship. By elucidating the connection between consanguine brothers and governance we are more aware of how fifteenth-century authors utilized the Arthurian world to promote or warn against the centrality of fraternity and governance.

In the final chapter, I turn my attention to fraternity and the rise of the gentry class. ${ }^{43}$ I examine the romance The Tale of Gamelyn and focus on the issues of fraternity and governance which arise directly in response to questions of inheritance within latemedieval England. This poem centers on the volatile relationship which emerges between brothers when they become rivals for the property of their father. The chapter engages

\footnotetext{
42 Recent scholarship which also puts Malory in conversation with other texts includes the works by Larrington and Leitch outlined above. An earlier example which also puts Malory in conversation with Lydgate is Catherine Nall, Reading and War in Fifteenth-Century England: From Lydgate to Malory (Cambridge: D. S. Brewer, 2012). See particularly, 75-113.

43 For a detailed exploration of the rise of gentry romance, see Michael Johnston, Romance and Gentry in Late Medieval England (Oxford: Oxford University Press, 2014).
} 
with the way in which brothers, meant to be close allies and to provide mutual support, could theoretically become competitors. This sense of competition harkens back to Chapters One and Two, and the behaviour of brothers towards one another once again becomes a way in which to judge the moral character and virtue of the individual. Unlike the Siege of Thebes and the Arthurian stories, the Tale of Gamelyn does not focus on kings and princes, but instead demonstrates that fraternity and governance are also concerns for classes beyond royalty. Gamelyn explores the volatile relationship between Johan and Gamelyn when they become obstacles for each other in obtaining their late father's land. Throughout Gamelyn, fraternity, and the acceptance or rejection of it, becomes a way in which to maintain or deny gentry class position.

I also examine wills and personal letters from the period to trace how the concerns and anxieties found within the romance text were present in the minds of fifteenthcentury gentry individuals. In my examination of the wills, I argue that their construction demonstrates anxiety over the likelihood of brothers to look after one another, an apprehension similar to the underlying anxiety in Gamelyn. In both the poem and the wills, we witness fathers who attempt to look after all their sons, fearing that the laws of primogeniture, which favour inheritance by the eldest son alone, may mean that younger sons will lose their ability to maintain their social class and position. In the letters I inspect the formulaic language of fraternal terms of address, used also by the author of Gamelyn, which are meant to evoke specific emotions and obligations in order to motivate particular actions benefitting the author of the letter.

This dissertation traces an arc of invocations of brotherhood in the fifteenth century, beginning with fifteenth-century depictions of foundational tales of brothers 
from Scripture and Classical tradition, proceeding through Arthurian models of consanguine brotherhood at both the start and end of Arthur's reign, and concluding with a consideration of the depiction of brotherhood in texts concerned with the gentry class. I outline the varying and connected ideas of fraternity which permeated the literature of late-medieval England, demonstrating the power of consanguine brotherhood, and the obligations associated with such a bond, on the cultural imaginary of the period. These authors all engage with questions of what it means to be a brother and the power and influence of such a bond upon the larger cultural and political world, beyond the confines of the individual men involved in these relationships. 


\section{Chapter One: Cain and Abel: Scriptural Origins}

Fifteenth-century political, social, religious, and economic organizations in England often upheld fraternity as their model of interpersonal connection, and the breakdown of the model could have devastating consequences for these powerful establishments. While later chapters will address other traditions of fraternity, such as classical origins of brothers and Arthurian fraternity, in this chapter, I focus on the scriptural origins of fraternity as found within the story of Cain and Abel. Appearing in Genesis, the story of Cain and Abel is a foundational tale of brothers in the JudeoChristian and would have been a widespread cultural reference in medieval Europe. From sermons to cycle plays, the relationship between these brothers was utilized as a warning to audiences about the dangers of being ruled by greed, jealousy, and anger. Cain's murder of Abel, a result of his excessive anger and jealousy, demonstrates the devastating consequences of a lack of self-control as well as a lack of fraternal love. Those consequences are evoked in the sermons and the cycle plays to counsel medieval audiences to avoid behaving like Cain, and to conduct themselves without being controlled by jealousy and anger. The story of Cain and Abel may be the foundational tale of brotherhood in the Christian world, but it is a story of fraternity fraught with rivalry and fratricide.

With the prominence of fraternity in governing organizations, the possibility of fratricide and fraternal feuding remained an active concern in the fifteenth-century cultural imagination. While there are seemingly no documented cases of fratricide in the judicial documents of the late-medieval period in England, its appearance in several 
examples of fifteenth-century English literature suggests that medieval authors actively explored this ultimate betrayal of the ideal social bond of fraternity. This meant readers, too, were forced to grapple with the concept. Fratricide, both intended and accidental, represents the breakdown of a prominent social bond, one which could theoretically have far-reaching implications. From the sermons they heard within the churches to the plays witnessed in their streets, late medieval audiences were often confronted with this origin story of brotherhood and its inherent connection to fratricide.

Beyond a representation of interpersonal conflict and familial strife, fratricide in the literature of the fifteenth century is also a representation of the breakdown of governance. Throughout this dissertation, I demonstrate the correlation between fraternity and governance, between fratricide and chaos. Subsequent chapters, while focused on other elements of fraternity, will also return to the topic of fratricide, demonstrating the use of fratricide in medieval re-imaginings of classical tales, in Arthurian literature, and in gentry romances. In the case of biblical and fifteenth-century versions of the story of Cain and Abel, fratricide is the outcome of a lack of self-governance. Cain's inability to master his own emotions and disappointment becomes manifest when he slays Abel, committing the first fratricide in the Judeo-Christian narrative. Fraternal competition is both a cause and a sign of poor governance. In this instance, Cain's lack of selfgovernance is both a response to his having lost a competition with his brother and his reason for viewing his brother as competition at all.

I first examine the story of Cain and Abel as presented in Genesis, in both the Vulgate and the Lollard versions of the Bible, exploring the way in which the very first brothers also represent the very first fraternal conflict. In Genesis, we see Cain's inability 
to govern himself, and he loses all semblance of self-control. Next, I consider examples of the ways in which the story of Cain and Abel was utilized in sermons from the fifteenth century. Finally, I turn to the tale as it was presented on the medieval stage. I examine the major cycle pageants from Chester, N-Town, Towneley, and York, outlining the similarities and differences between these four representations of the tale and the depictions of fraternity and fratricide within them. Across these three genres of literature, Cain's behaviour represents a lack of self-governance which manifests itself in the ultimate betrayal of fraternity. While in later chapters I examine the connection between poor self-governance and the political governance of rulers and leaders, and how poor governance in both cases is associated with fraternal strife, this chapter focuses on the utilization of Cain as an exemplar to Christian audiences of how not to govern themselves. Cain's willingness to commit fratricide is a demonstration of his lack of selfgovernance and its dire consequences.

\section{Cain and Abel in Genesis}

The story of Cain and Abel appears in Chapter Four of the Book of Genesis. ${ }^{1}$ It begins with the description of Cain and Abel's birth and the two are immediately identified as brothers, as Eve gives birth first to Cain, followed by Abel: "Rursumque peperit fratrem ejus Abel" (And again she brought forth his brother Abel) (Genesis 4.2). We are informed that Cain is a husbandman while Abel is a shepherd. The brothers both

\footnotetext{
${ }^{1}$ All scriptural quotations are taken from Biblia Sacra Vulgata (Clementine Version): Translation from Greek and other languages into Latin by Saint Jerome, about 382 A.D. , www.drbo.org/lvb/index.htm. All translations of the scriptural passages are taken from The Holy Bible, Douay-Rheims Version. With revisions and footnotes (in the text in italics) By Bishop Richard Challoner, 1749-52, www.drbo.org/index.htm.
} 
must make an offering to God that reflects their individual ways of life. The first indication that the brothers might view one another as competition occurs when they make offerings to God:

Factum est autem post multos dies ut offerret Cain de fructibus terrae munera Domino. Abel quoque obtulit de primogenitis gregis sui, et de adipibus eorum : et respexit Dominus ad Abel, et ad munera ejus. Ad Cain vero, et ad munera illius non respexit : iratusque est Cain vehementer, et concidit vultus ejus.

(And it came to pass after many days, that Cain offered, of the fruits of the earth, gifts to the Lord. Then Abel also offered of the firstlings of his flock, and of their fat: and the Lord had respect to Abel, and to his offerings. But to Cain and his offerings he had no respect: and Cain was exceedingly angry, and his countenance fell.) (4.3-5)

God reprimands Cain for his response, and in anger Cain turns to Abel and convinces his brother to follow him out into the field. While there, Cain kills Abel (4.8). The story of Cain and Abel, while spanning only a few short lines, immediately presents Christian fraternity as inherently wrought with the potential for conflict. Brotherly love may be considered inherently natural to fraternal relationships, but it is also something which must be actively chosen and willingly honoured, something which Cain refuses to do. In the Vulgate version of Genesis 4.1-15, the term "frater" ("brother") is used seven times, with all but one of those being directly related to the actual moment of Abel's murder. This is true as well of the Wycliffite translation, with the term "brother" 
appearing on seven occasions within the first fifteen lines of Genesis $4 .^{2}$ The term is used to initially identify the relationship between Cain and Abel at their births and then does not reappear until Cain plots to kill Abel:

Vulgate:

Dixitque Cain ad Abel fratrem suum: Egrediamur foras. Cumque essent in agro, consurrexit Cain adversus fratrem suum Abel, et interfecit eum. Et ait Dominus ad Cain: Ubi est Abel frater tuus? Qui respondit: Nescio : num custos fratris mei sum ego? Dixitque ad eum: Quid fecisti? vox sanguinis fratris tui clamat ad me de terra.

(And Cain said to Abel his brother: Let us go forth abroad. And when they were in the field, Cain rose up against his brother Abel, and slew him. And the Lord said to Cain: Where is thy brother Abel? And he answered, I know not: am I my brother's keeper? And he said to him: What hast thou done? the voice of thy brother's blood crieth to me from the earth.) Wycliffite:

Cayn seide to Abel his brother, Go we out. And whanne thei weren in the feeld, Cayn roos azens his brother Abel, and killide him. And the Lord seide to Cayn, Where is Abel thi brother? Which answerde, Y woot not; whether Y am the kepere of my brothir? And God seide to Cayn, What

\footnotetext{
${ }^{2}$ The Holy Bible, Containing the Old and New Testaments, with the Apocryphal Books, in the Earliest English Versions, Made from the Latin Vulgate by John Wycliffe and His Followers, eds. Rev. Josiah Forshall and Sir Frederic Madden, vol 1, 85-86 (Oxford: Oxford University Press, 1850).
} 
hast thou do? the vois of the blood of thi brother crieth to me fro erthe.

(Genesis 4.8-11, emphasis mine)

The term "brother" is utilized by the narrative not in place of Abel's name, but in addition to it. Both the narrative and God's direct speech use "brother" and "Abel" to emphasize the relationship of Abel to Cain. Cain only uses the term and not Abel's name when he denies responsibility for both Abel's death as well as his brother in general, asking if he is his "brother's keeper." Abel never uses the term, as in Genesis he does not speak. ${ }^{3}$ Abel's relation to Cain is emphasized through the evocation of the term, and Cain's acknowledgement of the relationship of fraternity between them heightens the abhorrent nature of his crime. Cain has allowed emotion to rule him, and his loss of selfcontrol is marked by the loss of his brother as well. When Cain's self-governance fails, his fraternity suffers.

Notably, it is only after Cain has committed fratricide that the importance of fraternity and the obligations associated with it are raised. It is only after Abel's death that Cain is chastised for not looking after his brother. It is after he has killed Abel that Cain realizes that he is charged with being his "brother's keeper." Though fraternal affection and loyalty are meant to be inherent within brothers, Cain's rejection of these emotions demonstrates that brothers must actively chose to accept fraternal love and behave accordingly. The possibility and option to reject the nature of the fraternal bond is always present. Cain's lack of self-governance is immediately followed by a refusal to accept governance over his brother. The fratricide of Abel represents both a lack of

\footnotetext{
3 For a discussion of Abel's lack of voice until we are told that his blood cries out to God, see John Bryon, "Abel's Blood and the Ongoing Cry for Vengeance," The Catholic Biblical Quarterly 73 (2011): 743-56.
} 
governance and a refusal. When Cain is questioned by God, he attempts to deny any responsibility for his brother, a responsibility which was not explicitly implied until the moment of Abel's death. The obligations of fraternity which ought to have governed Cain's behaviour towards his brother are established after Cain has already failed the test.

In its biblical origins, evidence of fratricide is older than the presentation of brotherly love precisely because the first brothers are also the first to be in competition with one another, though the existence of this rivalry is not explicitly stated before Cain reacts in anger to having, in his mind, lost the competition. ${ }^{4}$ The brothers go to tithe together and by doing so, they enter into competition with one another for God's favour. As Rein Nauta argues,

Their offerings are not just a sign of gratitude but also a request for the recognition and confirmation needed to live in a threatening world ruled by doubt and uncertainty... To learn that one brother is accepted and preferred, and that the other is disregarded and rejected in what appeared to be a peaceful offering out of simply thankfulness but turned out to be a struggle for love and confirmation, is disturbing and threatening."

The tithe becomes a test for the brothers, and it appears that, for whatever reason, Abel passes while Cain does not. However, it is not Cain's offering which is, at least in Genesis, the most problematic; rather, his error stems from the decisions he makes in the face of rejection. Cain's poor choices are the result of poor self-governance. However,

\footnotetext{
${ }^{4}$ In the case of Cain and Abel, their competition is not for physical items nor positions of power over others and land, but rather for favour and love of God. The next chapter will explore brothers who compete for the right to rule and to claim land and people as their own.

${ }^{5}$ Rein Nauta, “Cain and Abel: Violence, Shame and Jealousy," Pastoral Psychology 58 (2009): 68.
} 
Cain's inability to govern himself properly is perhaps not surprising. Chaya Greenberger argues that "Cain and Abel grow up in a post-Eden reality" and because of this "[h]uman choices are no longer based upon right or wrong in an objective sense but involve subjectivity" and "this opens up the possibility for morally flawed choices. Cain was the first to be challenged by this new reality." "In Genesis, Cain's response to God's rejection, rather than Cain's tithing, is the real failed test. Cain's inability to control his own emotions is what ultimately leads him to commit fratricide.

The story as it appears in Genesis establishes the immediate correlation between Cain's actions and his lack of self-governance. When Cain's offering is not accepted and becomes upset, God challenges his response:

Dixitque Dominus ad eum: Quare iratus es? et cur concidit facies tua? nonne si bene egeris, recipies: sin autem male, statim in foribus peccatum aderit? sed sub te erit appetitus ejus, et tu dominaberis illius. (And the Lord said to him: Why art thou angry? and why is thy countenance fallen? If thou do well, shalt thou not receive? but if ill, shall not sin forthwith be present at the door? but the lust thereof shall be under thee, and thou shalt have dominion over it.) (Genesis 4.6-7)

God questions Cain not for his offering but for his attitude and behaviour. Cain's disappointment and anger are the problem. God specifically tells Cain that he has the ability to exercise "dominion over" sin, criticizing Cain's emotional response rather than the content of his tithe. God does not tell him to tithe better; he tells him to manage his

${ }^{6}$ Chaya Greenberger, "Cain and Able: (Mis) Managing Rejections and Unmet Expectations," Jewish Bible Quarterly 44, no. 2 (2016): 116. 
own expectations and his attitude. However, this only increases Cain's anger, and that anger becomes manifest when he slays Abel. Rather than turning inward and confronting his own limitations and errors, Cain allows his emotions to turn outward in hatred of his own kin. The fratricide of Abel is a direct result of Cain's inability to govern his own emotions. As Greenberger argues, "instead of reprimanding Cain for his emotional reaction, [God] shows fatherly concern." ${ }^{77}$ God explicitly encourages Cain to control himself and his behaviour. Cain rejects this advice, failing to pass the test he has been given by God when he allows his anger to get the better of him.

While the competition between Cain and Abel can be likened to that of siblings vying for their father's love and attention, Cain's anger is directed not at the father-figure he disappointed but, instead, at his competition: Abel. Abel's position as his brother also means he is Cain's biggest source of rivalry. Greenberger suggests that "Cain was convinced of his superiority to Abel in all matters, material and spiritual. Cain's rejection was thus totally unexpected; he was furious due to the perceived injustice of the rejection, but also depressed due to the deflation of his self-esteem." ${ }^{8}$ Fraternity, instead of signifying a bond to one's closest ally, becomes the source of competition, a pattern of fraternity and rivalry in Genesis which is not limited to the Cain and Abel story. As Carolyn Larrington observes:

Genesis emphasizes recurrent patterns of competition and rivalry between pairs or larger groups of brothers. From the primal murder of Abel by Cain (Genesis 4) and Abraham's willingness to dismiss Ishmael and his mother

\footnotetext{
7 Greenberger, 117.

8 Ibid..
} 
in favour of the late-born Isaac (Genesis 21) ... Genesis consistently

shows one brother as chosen and one as lacking in favour, both in the eyes

of his parents and in the sight of God. ${ }^{9}$

Brothers in Genesis, and thus in the beginning of Christian theology, are also rivals. While they represent one of the closest bonds a person can have, and brotherhood is the model upon which Christian men understand their relationship to one another, it is still a source of potential, or even inevitable, tension. Fratricide occurs not as a deviation away from productive brotherhood but, rather, as the first context in which brotherhood exists. Your brother, as seen in the example of Cain and Abel, is the one who has the most potential to surpass you in the eyes of your parents, or the Lord. Transgressions against brothers are demonstrative of an inability to govern oneself. Poor governance is often marked by poor fraternity, a correlation present in the very beginning of Christian brotherhood. As I will examine in subsequent chapters, this lack of self-governance and its manifestation in fratricide intensifies as the correlation is further explored beyond its biblical origins in the literature of the fifteenth century.

The story of Cain and Abel, and its associated morals, was also utilized within the New Testament as a warning against repeating Cain's transgressions. Tom Thatcher argues that one of the reasons why Cain and Abel are referenced in the New Testament is to scrutinize moments in which "Christian communities were divided by serious doctrinal differences" as "the evocation of Cain and Abel could explain the emergence of tensions between 'brothers' in terms that would valorize one's own position while villainizing that

\footnotetext{
${ }^{9}$ Larrington, 13.
} 
of the opponents." 10 Thatcher provides the example of Jude 11, in which "Jude asserts, without elaboration, that his opponents 'have gone the way of Cain." He elaborates, stating that:

In Jude's application, orthodox Christians (including Jude himself) play the part of righteous Abel, whose sacrifice - in this case, a correct Christology and corresponding lifestyle - is acceptable to God. Cain, by contrast, represents those who bring an irregular offering - in this case, a deviant doctrine and corresponding behaviors - that is rejected by the Lord. Further, the opponents, like Cain, respond to the opportunity to repent by threatening their 'brothers' in the church, a predictable course of action in view of their significant character flaws. ${ }^{11}$

Christians, inherently aware of the relationship of Cain and Abel, would need little more context than this to understand the purpose of such passages in warning against division within the Christian community.

\section{Fifteenth-Century Sermons}

Cain's lack of self-governance is utilized within fifteenth-century sermons as warnings against allowing oneself to lose control over one's emotions. ${ }^{12}$ The sermon format, while certainly not unique to late medieval England, does appear "to have

\footnotetext{
${ }^{10}$ Tom Thatcher, "Cain and Abel in Early Christian Memory: A Case Study in 'The Use of the Old Testament in the New'," The Catholic Biblical Quarterly 72 (2010): 740.

11 Thatcher, 747.

12 While my work here examines the use of Cain and Abel in these two genres, I do not focus on the nature of sermons within medieval drama. For a recent study which does explore this connection more in depth, see Charlotte Steenbrugge, Drama and Sermon in Late Medieval England: Performance, Authority, Devotion (Kalamazoo: Medieval Institute Publications, 2017.)
} 
experienced a revival in the late fourteenth and early fifteenth centuries." ${ }^{13}$ The fact that in the fifteenth century several sermons turn to the story of Cain and Abel to warn against the dangers of poor self-governance is an example of the period's interest in the potential dangers of fraternal strife. Cain's murder of Abel is not necessarily directly evoked, but the story would have been familiar enough to the audience that they would have immediately associated him with the act of fratricide. While it does not appear to have been necessary to warn the congregation about the evil of committing fratricide, the sermons use the figure of Cain to warn against more generalized sinful behaviour. One of the ways late-medieval preachers utilized Cain's behaviour in their sermons was to demonstrate poor behaviour in general, employing Cain's actions as signs of all manners of poor self-governance, attitude, and Christian behaviour. For example, we see both Cain's anger and the lie he tells when God asks him about Abel deployed as examples of poor behaviour in a Dominican Sermon cycle from the late fifteenth century. Cain's lie is included on a list of behaviours to avoid, given during the first sermon of Lent: "The perd poynt is that he schall sey the trowpe and not lye as Caym dyd when he had sleyn Abel his broper." ${ }^{14}$ Cain's refusal to acknowledge and admit when he had killed Abel is demonstrated here as a behaviour unbecoming of a good Christian. In the same sermon cycle we see Cain's behaviour explained as being a result of his envy: "Inuidia que fecit Caym occidere fratrem suum Abel. 'Envy was cawse that Caym slowze his broper Abel." ${ }^{15}$ Cain is utilized in the sermons as an example of someone whose behaviour

\footnotetext{
13 Ibid., ix.

14 "Lent - Sermon 1" in A Late Fifteenth-Century Dominical Sermon Cycle, ed. Stephen Morrison, vol 1, EETS o.s. 337 (Oxford: Oxford University Press, 2011), 118.197-8.

15 "Trinity 5," 268.93-94.
} 
should be avoided, as his inability to govern his own envy led to the murder of Abel. Fratricide is a result of failure to avoid envy, one of the seven deadly sins all Christians are meant to avoid.

The act of tithing is also associated with the importance of self-governance, as seen in the sermon "Dominica vj, post Festum Sancte Trinitatis." This sermon specifically outlines for the audience that they should not make offerings to God if they find themselves at odds with their "brothers":

Moreover, seythe Criste in pis gospell, if pu schalt offer eny maner of zefte to the awter of God, and haste eny maner of malic vnto thi brother, leve there thi zefte before the awter, and then go to be reconsiled to pi broper and in charite be acordyd withe hym. And pen schalt pu come azene and offer vp pi zefte to God. ${ }^{16}$

While the term "brother" is meant in the general sense of Christian brotherhood, it is still significant that this relationship is referenced in the advice. The congregation are reminded that to make an offering to God, their attitudes and behaviours must align with those offerings. Anger such as Cain's is not appropriate for tithing. Cain and Abel may not be evoked in this instance, but as a story that would be familiar to the congregation, it is entirely likely that that connection would have been made. As Cain's offering is not accepted and he becomes angry. This sermon specifically warns against anger towards one's brother and encourages the congregation to settle those feuds before coming to God with their own offerings. In this same sermon, the congregation are also warned against letting anger overcome them:

${ }^{16} 277.120-23$. 
And pus pese vj synnes folowithe there broper wrathe, pe whiche is forboden vs by the prophete Daniel: Nolite irasci cum fratribus vestris, ne forte Deus irascitur vobiscum: 'Be ze not wrothe withe zowre brethern, ne withe 3owre ney3bors lest pat God wex wrothe withe 3ow. ${ }^{17}$

The sermon once again emphasizes anger as an emotion which must be controlled. It also re-emphasizes the danger of that anger when directed at a "brother." The above statement warns the congregation not to be angry with either brother or neighbour, or God might be angry with them. The audience is told to govern their own emotions to please God. To be a good member of fifteenth-century Christian fraternity, one must avoid behaving like Cain.

A similar warning against anger, especially towards one's Christian brethren, is also found in a Wycliffite sermon: "And perefore 3if pow offre pi zifte to God, pat pe scribes preysen myche, and pow penke pat pi bropir for pi synne haue any cause azeynes $p e$, leue pin offryng at pe auter and go furst to ben accorded wip hym." ${ }^{18}$ Once again, the sermon warns that anger, especially towards fellow brethren, is not an appropriate emotion to have when making an offering to God. The offering can wait until you have settled your feuds with your brothers. To make a successful offering to God, you must be in control of your own behaviour and emotions - precisely what Cain was unable to do. Again, while not evoking the names Cain and Abel, the image of tithing and anger at one's brother likely allowed the audience to make the association to the tale, as Cain's failed offering led directly to the murder of his brother. With the story of Cain and Abel

\footnotetext{
17 278.132-36.

18 "Sermon 6," in English Wycliffite Sermons, edited by Anne Hudson (Oxford: Clarendon Press, 1983), 247.74-77. Emphasis original.
} 
coming so early in Genesis, it is likely that any Christian in the period could have regarded the word "brother" as inherently haunted by this tale of fratricide. It suggests that while fraternal love may be viewed as an ideal, it is an ideal which must be actively chosen and upheld.

\section{The Cycle Pageants}

The story of Cain and Abel is included in all four of the major cycle pageants of the period: Chester, N-Town (also referred to as the Hegge Cycle), Towneley (most likely performed at Wakefield), and York. These pageant cycles, also known as the Corpus Christi Cycle, present a series of shorter performances taken from significant events in both the Old and New Testament. The performances were sometimes, but not necessarily, performed by the craft guilds within those cities. Each story was a pageant in a longer performance which often, but again not always, took place on the Feast of Corpus Christi. ${ }^{19}$ The cycle pageants take the details found within Scripture and present them on the stage, often elaborating on the events and plot to form a full scene or short play. The plays offered audiences the opportunity to witness stories from Scripture in person. As E. Catherine Dunn argues, the "accessibility of the Scriptures to the entire people, not through manuscripts but through the annual Corpus Christi plays, served as a source of information and instruction." ${ }^{20}$ The pageants, in this way, could be used not only to entertain but also to reinforce moral lessons, such as those outlined in the sermons

\footnotetext{
${ }^{19}$ For a more detailed description of the Corpus Christi Cycle, see Richard Beadle, "The York Cycle," in The Cambridge Companion to Medieval English Theatre, ed. Richard Beadle, 85-108 (Cambridge: Cambridge University Press, 1994).

${ }^{20}$ E. Catherine Dunn, "Popular Devotion in the Vernacular Drama of Medieval England," Medievalia et Humanistica n.s. 4 (1973): 55-68.
} 
studied above. While the Cain and Abel play, and the cycle pageants in general, provided entertainment, I argue that they also re-emphasized the dangers of Cain's anger and his inability to govern his own emotions through the dramatization of his murder of Abel.

The cycle pageants represent another example of the way in which fifteenthcentury audiences and authors engaged with the inherently complicated relationship of fraternity and governance. While these plays and their manuscripts were known both before and beyond the fifteenth century, there is ample evidence to indicate they also had specific relevance to the period. Alexandra F. Johnston summarizes, for example, that the York Cycle "is early fifteenth-century in concept; its text (or at least the largest part of its text) was committed to the manuscript we have in the third quarter of the fifteenth century." 21 The Chester Cycle, whose extant manuscripts all date from the sixteenth century, appears to have been first performed in 1422. The first recorded performance of the Adam and Eve play in this cycle was in 1467-68, as performed by the Drapers. ${ }^{22}$ As Peter Happé argues, "we can say that the evidence from the large number of surviving plays suggests that while some early cycle plays can be found in the fourteenth century, or even earlier, the period of greatest growth and popularity is apparently from about 1450 onwards." 23 These plays, then, while relevant both before and after the fifteenth century, are still important documents for an understanding of the representation of fraternity and governance in that period. As I will further demonstrate in the following

\footnotetext{
${ }^{21}$ Alexandra F. Johnston, "The York Cycle and the Chester Cycle: What do the Records Tell Us?" in The Chester Mystery Cycle: A Casebook, ed. Kevin J. Harty (New York and London: Garland Publishing, 1993): 20.

22 Lawrence M. Clopper, "The History of the Development of the Chester Cycle," Modern Philology 75 (1978): 243.

${ }^{23}$ Peter Happé, Cyclic Form and the English Mystery Plays: A Comparative Study of the English Biblical Cycles and Their Continental and Iconographic Counterparts (Amsterdam; New York: Rodopi, 2004$), 13$.
} 
chapters, engagement with the connection between self-governance and fratricide witnessed in the plays is representative of the cultural imagination of the period, in which authors continued to grapple with the inherently fraught relationship of brotherhood. While the texts I study in later chapters examine the ramifications of dangerous fraternity for the community and kingdom at large, the plays demonstrate anxiety over the ability to self-govern and question what it means to be a Christian brother.

For the purposes of my study, I focus on the written documents of the plays - the physical scripts which have survived from the period - and while I do speak to the effect that seeing Abel's murder might have on an audience, I acknowledge that much of my analysis is based upon the written text. My arguments are about the types of emotions and responses the text of the plays attempt to evoke within the language as it is written, recorded, and maintained. This method, while valid, does come with its own concerns. J. W. Robinson argues that "[m]edieval biblical plays were written to be performed" and laments that "it is not uncommon to find them considered as literature only, and questions concerning their performance regarded as trivial." ${ }^{24}$ My purpose in this chapter is to consider the ways in which fraternal terms of address were employed in the plays, which would have been spoken by the actors, heard by the audience, recorded by the scribe, and potentially read by those who had access to the manuscripts. I can make no definitive answers as to what the audience and actors alike would have felt or thought during the performance. Instead, I propose possible connections between the ideas and concerns of the staging of Abel and other literary and lived experiences of the fifteenth century. I

${ }^{24} \mathrm{~J}$. W. Robinson, Studies in Fifteenth-Century Stagecraft (Kalamazoo: Medieval Institute Publications, 1991), 1. 
focus on the literary aspect of the plays and the utilization of fraternal terms of address. Through this careful study of language, there emerges a connection between the plays performed and the sermons delivered in fifteenth-century England, indicating a wider cultural, religious, and social preoccupation with the connection between self-governance and fraternity.

The Cain and Abel tale varies significantly across the four pageant cycles, and the usage of fraternal terms is also necessarily diverse across the texts. In the following chart, I have calculated the usage of the term "brother" in each cycle. I have divided the usage by character to demonstrate the specific ways in which fraternal terms of address are utilized.

\begin{tabular}{|l|l|l|l|l|}
\hline Cycle & Total lines & $\begin{array}{l}\text { Usage of Term } \\
\text { by Cain }\end{array}$ & $\begin{array}{l}\text { Usage of Term } \\
\text { by Abel }\end{array}$ & $\begin{array}{l}\text { Usage of Term } \\
\text { by other } \\
\text { characters }\end{array}$ \\
\hline Chester & $\begin{array}{l}280 \\
(704)^{25}\end{array}$ & $\begin{array}{l}\text { To Abel: } 0 \\
\text { About Abel: } 3\end{array}$ & $\begin{array}{l}\text { To Cain: } 1 \\
\text { About Cain: } 1\end{array}$ & $\begin{array}{l}\text { God: } 4 \\
\text { Adam: 1 (In the } \\
\text { Creation and the } \\
\text { Fall section) }\end{array}$ \\
\hline N-Town & 195 & $\begin{array}{l}\text { To Abel: } 1 \\
\text { About Abel: } 1\end{array}$ & $\begin{array}{l}\text { To Cain: 3 } \\
\text { About Cain: } 1\end{array}$ & God: 2 \\
\hline Towneley & 473 & $\begin{array}{l}\text { To Abel: } 1 \\
\text { About Abel: } 3\end{array}$ & $\begin{array}{l}\text { To Cain: } 17 \\
\text { About Cain: 0 }\end{array}$ & $\begin{array}{l}\text { God: } 3 \\
\text { Garcio: 1 }\end{array}$ \\
\hline York & 139 & $\begin{array}{l}\text { To Abel: 0 } \\
\text { About Abel: } 0\end{array}$ & $\begin{array}{l}\text { To Cain: 3 } \\
\text { About Cain: 0 }\end{array}$ & Angelus: 1 \\
\hline
\end{tabular}

As the chart indicates, each play has a distinct variation in the usage of the term "brother." From Chester, in which we never see Abel use the term as a form of address to

\footnotetext{
25 In the Chester Mystery Cycle, the story of Cain and Abel appears within the second pageant which begins with the story of Creation and Adam and Eve. I have given the total number of lines in parentheses and noted any use of the term "brother" in the entire play separately from the section focused on Cain and Abel. In starting at line 425 , I follow other scholars in viewing the stage direction of "minstrelles play" in between lines 424 and 425 as the separation between the two sections of the play.
} 
Cain, to Towneley, in which Abel consistently calls Cain "brother," each play has its own method of representing the story of the first fratricide, and each has unique features which help reinforce the lessons or warnings of the tale. For the purposes of this chapter, I focus my discussion on the Chester, N-Town, and Towneley Cycle as examples of the use of the Cain and Abel story on the medieval stage. My reasoning for excluding the York cycle from further in-depth analysis is the fact that several lines are missing from the original manuscript, including those spoken by Cain and Abel, and thus a thorough assessment of the terminology of this play would be impossible. The Chester, N-Town, and Towneley plays all present the story of Cain and Abel, dramatizing the event by expanding upon the story as found in the few lines of Genesis. Each play represents similar, yet divergent understandings of the way in which Cain's fratricide of Abel is a lesson in self-governance as well as fraternal behaviour.

\section{The Chester Cycle}

The Chester cycle is found in its entirety in five surviving manuscripts, and fragments of the cycle are found in three more ${ }^{26}$ All of the manuscripts date from as early as the late fifteenth century and as late as the early seventeenth century. In the Chester Cycle, the story of Cain and Abel is not a separate play on its own, but rather is

\footnotetext{
${ }^{26}$ Manchester, Manchester Central Library, MS.822. IIC2; Aberystwyth, National Library of Wales, Peniarth 399; San Marino, Henry E. Huntington Library and Art Gallery, MS. 91108; London, British Museum, Additional 10305; Chester, Chester Cooper's Guild; London, British Museum, Harley 2013; Oxford, Bodleian Library, Bodley 175; London, British Library, Harley 2124. For more detail on the manuscripts, see The Chester Mystery Cycle, eds. R. M. Lumiansky and David Mills, EETS, SS 3 (Oxford: Oxford University Press, 1974), ix-xxvii. See also: David Mills, "Theories and Practices in the Editing of the Chester Cycle Play-manuscripts," in The Chester Mystery Cycle, ed. Kevin J. Harty, 3-17 (New York and London: Garland Publishing, 1993).
} 
part of the second play, performed by the Drapers and covering the entirety of the "Adam" story. ${ }^{27}$ The Chester version of the play slowly establishes the problematic nature of Cain's behaviour. From his reason for tithing to his response to God's rejection, Cain's poor governance of both his expectations and behaviour builds upon the story as found Genesis. The story of Cain and Abel in the Chester cycle reinforces the fact that Cain's expectations of favour and his inability to govern his anger and envy are directly responsible for the first fratricide. Cain's inability to self-govern becomes manifest in his anger towards Abel, whom he views not as an ally but as a competitor.

In this version of the story, Adam assigns his children to their trades: "Cayne, husbandes crafte thou must goe to; / And Abell, a shepharde bee" (475-76). ${ }^{28}$ When the brothers first come to tithing, the play establishes a reason for God's rejection of Cain's sacrifice that is absent in Genesis. Cain says:

Of corne I have great plentee; sacrifice to God soon shall yee see. I will make too looke if hee will sende mee any more. (517-20)

Cain, while apparently eager to make his sacrifices, voices the expectation that he will be given something in return for the offering. Cain expects that God will honour him and his

\footnotetext{
${ }^{27}$ As Martin Stevens points out the play is entirely self-contained: "Unlike the N-Town cycle, Chester maintains clear demarcations among its twenty-four pageants. In the manuscripts, each pageant carries the title of its sponsoring guild, followed by the pageant number, and in some, the title of the episode proper." See Martin Stevens, Four Middle English Mystery Cycles: Textual, Contextual, and Critical Interpretations (Princeton: Princeton University Press, 1987), 269.

${ }^{28}$ All references to the Chester Cycle refer to: "Adam and Eve; Cain and Abel - The Drapers," in The Chester Mystery Cycle, eds. R. M. Lumiansky and David Mills, EETS s.s. 3, vol 1, 13-41 (London: Oxford University Press, 1974.).
} 
tithe with even more crops. He does not give freely. This is immediately contrasted by

Abel's offering, as he makes his own vow:

And I will with devotion

to my sacrifice make mee bowne.

The comeliest beaste, by my crowne,

to the lorde I will choyse

and offer yt before thee here,

meekyle in good manere. (521-26)

Unlike Cain, Abel vows to make his offering without any sort of expectation of reward.

Abel's vow contradicts Cain's, serving as an instruction to the audience as to how they themselves should behave when making an offering to God. Not only should they offer freely and not because they expect reward, but they should do so "with devotion" and "meekyle in good manere." 29 This dissonance between the behaviours of brothers is further emphasized by the type of offering both make. Cain, demanding to go first as the elder of the two, offers God the worst of his crops: "such as the fruite if fallen froo / is good inough for him" and corn which "was eaten with beastes" (531-34). Cain states explicitly that God will "gettest noe other" of him (535). Abel, on the other hand, offers "the beste beaste" of all his "flocke with harte free" (557-58). God immediately accepts Abel's tithe, as the offering is set aflame. The immediate rejection of Cain's offering and

\footnotetext{
${ }^{29} \mathrm{~A}$ similar contrast between Cain and Abel's attitudes is present in the York version of the play as well. Abel makes a promise to God that he will give freely to God from his flock and invited Cain to do the same: "Come, brother Cayme, I woulde we wente, / with hert ful hende" (43-44). Cain refuses to give his good produce, and is angry at the suggestion, even before he begins tithing. See "Sacrificum Cayme and Abell," in The York Plays, vol. 1, ed. Richard Beadle. EETS, s.s. 23, 35-39 (Oxford: Oxford University Press, 2009).
} 
acceptance of Abel's is, in the play, a direct response to their behaviour in tithing. Unlike in Genesis, the audience can see a direct correlation between Cain's behaviour and God's refusal to acknowledge his tithe. The ability of the characters to self-govern their own expectations is directly correlated to their attitudes towards one another. Cain, who cannot control his own emotions, rejects the fraternity of Abel. Abel, on the other hand, controls his own expectations of what he is owed and, as we will see, trusts in the brotherly bond he shares with Cain.

Notably, Abel's response to Cain's behaviour is the first instance of the usage of the term "brother" in the play. Once Cain tithes, Abel states: "Now my brother, as I see, / hathe done sacrifice to thee" (553). Abel, despite Cain's behaviour, still aligns himself with his brother when addressing himself to God. Abel recognizes their relationship and fully embraces it. The first time Cain uses the term "brother" is not an acknowledgement of their close bond but rather an establishment of their rivalry. When God refuses to accept his offering, Cain complains:

A flame of fyer from heaven stood

one my brothers offering.

His sacrafice I see God takes, and my refuses and forsakes.

My semblant for shame shakes

for envy of this thinge. (569-76)

Cain uses the word brother when he believes he has been unjustly rejected. His response to God's actions is to view the tithes as competitive offerings, and he becomes envious of Abel. As seen in the sermon, Cain's behaviour leads to envy, one of the seven deadly 
sins. The play makes this perfectly clear by having Cain voice the emotion aloud. While Abel uses the term "brother" to identify his relationship with Cain, Cain uses it to identify the rivalry between them.

Abel is also the only one to use the term as a form of address in the play, as Cain never once calls Abel "brother" directly. In Abel's case the term is both ironically and tragically used at the very moment in which Cain is about to betray him. When Cain asks for Abel to accompany him on an errand, Abel responds:

Brother, to the I am ready

To goe with thee full meekly.

For thou arte elder then am I, thy will I will doe aye. (597-600, emphasis mine)

Abel acknowledges not only Cain's relation to him as a brother, but also his position as the eldest brother. Abel trusts Cain as his older brother and is willing to do as he says. $\mathrm{He}$ demonstrates the same willingness and meekness in behaviour towards Cain as he has towards God while tithing. He does not question why he must go with Cain, as he does not question why he must tithe. He does not consider his own benefit in either scenario. Abel's behaviour and attitude towards Cain is immediately contrasted when Cain attacks him in the field:

Say, thou caytiffe, thou congeon, weneste thou to passe mee of renowne?

Thou shalt fayle, by my crowne, of masterye yf I man. (601-4) 
Although Abel seems unaware of the rivalry between them, Cain blames him for winning the competition for God's affection and acceptance. Cain views Abel as his rival, and his anger leads him to kill his own brother. His inability to govern his own response to rejection causes him to project his anger onto Abel. Instead of questioning his own behaviour and attitude, he blames Abel for being better at tithing. Cain's response to the competition is to eliminate his opponent. As Dan Forsyth argues, "fratricide is the blunt, framing declaration of the utmost outcome of sibling rivalry." ${ }^{30}$ Despite Abel's lack of involvement in the rivalry, Cain is unable to overcome and control his own emotions enough to see Abel as his brother and not his rival.

God immediately reminds Cain of his fraternal relationship with Abel when he demands to know where Abel has disappeared: "Cayne, where is thy brother Abell?" (617) ${ }^{31}$ In response, Cain denies any knowledge of Abel's whereabouts, but also any responsibility for Abel: "I wote nere; I cannot tell / of my brother. Wottys thou not well / that I of him had noe keeping?" (618-20) Cain's statement not only denies the murder but also denies the fact that he was meant to look after Abel at all. Just as we have seen in Genesis, the charge of brotherly obligation is raised only after the duty of the bond has been neglected. It is another example of Cain's poor governance. As Abel reminds us, Cain is the elder brother and, as such, is meant to be a role model for Abel and a source

\footnotetext{
30 Dan W. Forsyth, "Sibling Rivalry, Aesthetic Sensibility, and Social Structure in Genesis," Ethos 19, no. 4 (1991): 478-79. This article also examines sibling rivalry in Genesis through "psychoanalytic anthropology, literary criticism, and biblical interpretation" and offers insight beyond the story of Cain and Abel, which I do not cover here in this chapter.

${ }^{31}$ God's appearance on stage to directly interact with the characters is more prominent in the Chester cycle than in any of the others, as highlighted by Kathleen M. Ashley. See "Divine Power in Chester Cycle and Late Medieval Thought," in The Chester Mystery Cycle: A Casebook, ed. Kevin J. Harty (New York and London: Garland Publishing INC., 1993), 51.
} 
of guidance and authority. Cain abuses that position, leading to the first fratricide in the Judeo-Christian narrative. Cain's impulsiveness is countered by Abel's moderated reactions when Abel, though asking God for vengeance for his murder (621-4), does not seek his brother's death:

Naye, Cayne, thou shalte not dye soone, horrybly if though have aye donne.

That is not thy brothers boone, thy blood to sheede. (649-52)

Despite Cain's actions, Abel does not want to spill his brother's blood. Even when seeking vengeance, Abel does not wish to be the cause of Cain's death. Abel refuses to participate in committing a fratricide of his own. Instead, Cain is sent into exile and given the opportunity to learn to govern his emotions. Cain, while exiled, is not punished with death. Following this, Cain finally takes responsibility for his actions, informing Adam and Eve of the deed: "I have slayne my brother Abell" (683). Cain must leave the family and his home with the knowledge that his own actions and emotions, and his failure to control his envy and anger, are the cause of his banishment. The Chester play builds upon the themes of governance and fraternity found in Genesis and dramatizes Cain's inability to manage either.

\section{N-Town}

The N-Town is the cycle of pageants which has received the least scholarly attention of the four main cycles. The cycle exists in a singular manuscript: London, 
British Library, Cotton Vespasian D.8, a collection of forty-one plays compiled in the late fifteenth century. ${ }^{32}$ Unlike the other cycles, this collection of plays is not associated with a performance in only one city. Instead, it is believed to have originated in the East Anglian region of England, and to have been compiled in the late $1400 \mathrm{~s} .{ }^{33}$ There are no guild records of ownership or involvement with these plays, nor records of any actual performance. However, the N-Town cycle was carefully compiled, and a close examination of the version of Cain and Abel present in this series of plays offers insight into yet another interpretation of the tale, which was likely performed in front of an audience. The Cain and Abel play immediately follows "The Creation of the World: Fall of Man," with no textual header or break in the narrative, apart from the character of Abel arriving to speak.

In fact, in the N-Town cycle, and only the N-Town cycle, Abel is the first to speak in the play. ${ }^{34}$ The play begins with his intentions to ask his father for advice on how to live well and please God, and he calls upon Cain to join him:

I wolde ffayn knowe how I shuld do to serue my lord god to his plesyng per fore Caym brother lete us now go

\footnotetext{
32 Gail McMurray Gibson traces the ownership and apparent origins of the manuscript, examining the importance of medieval drama manuscripts beyond the medieval period: "Manuscript as Sacred Object: Robert Hegge's N-Town Plays," The Journal of Medieval and Early Modern Studies 44, no. 3 (2014): 503529. See also: Alan J. Fletcher, "The N-Town Plays," in The Cambridge Companion to Medieval English Theatre, ed. Richard Beadle (Cambridge: Cambridge University Press, 1994.)

${ }^{33}$ Douglas Sugano goes so far as to argue that the collection of N-Town plays is "more an elegant compilation of different East Anglian games than a single organization's dramatic cycle." See "This Game Wel Pleyd in Good a-Ray': The N-Town Playbooks and East Anglian Games," Comparative Drama 28, no. 2 (July 1, 1994): 221.

${ }^{34}$ Abel does speak before Cain in the York cycle, but it is in response to the character of the Angel who instructs the brothers that they must offer tithings to the Lord.
} 
vn-to oure ffadyr with-owte lettyng

Good brother passe we hens

to knowe ffor oure levynge. (1-13). ${ }^{35}$

In the opening lines, the N-Town play raises the importance of both fraternity and of governance. To begin, Abel has already addressed Cain as "brother" twice in this very first speech of the play. The fraternity of Cain and Abel, while undeniably a recognized relationship in the minds of fifteenth-century audiences, is nonetheless reiterated twice at the opening of the play. The N-Town play puts fraternity at the forefront of the dramatic retelling of the story.

Abel's connection with his brother is further highlighted in his address to their father, asking how they might best please God. Abel, at the very least, views the upcoming tithing not as a competition, but as a joint endeavour. He wishes to know how they both might succeed in pleasing God with their offerings, viewing himself and Cain as companions and allies, not as competitive rivals:

Ryth sovereyn fadyr semely sad and sure

euer we thank zow in hert body and thowth

And alwey shull whyll oure lyf may indure

as inwardly in hert it kan be sought

bothe my brother and I. (23-27)

\footnotetext{
${ }^{35}$ All references to the N-Town play are taken from the following edition: "Cain and Abel," in Ludus Coventriae; or, the Plaie Called Corpus Christi, Cotton MS Vespasian D VIII, ed. Katherine Salter Block, EETS e.s. 120 (Oxford: Oxford University Press, 1922; rpt. 1960): 29-35. I have used "sh" in the place of " $x$ " when appropriate throughout my quotations.
} 
With his opening lines as well as this speech to his father, Abel inhabits a much more active role than witnessed in both the sermons and the Chester version of the play. Not only does this set Cain's actions in direct contrast to the behaviour of Abel, as seen in the Chester and Towneley plays, but this version of the tale explicitly sets Abel up as the model of behaviour from the very opening of the play. The N-Town emphasizes that Abel's actions - his mild manners, his desire to govern himself well under God, and his affiliation with his brother-are all ideal behaviours for fifteenth-century audience members to emulate. ${ }^{36}$

This is further highlighted through Abel's speech during his tithing to God, which is twenty-nine lines long. In his speech, Abel praises God and offers the best of all that God has given to him (62-91). Cain immediately insults his brother for such an act, calling Abel foolish, as "to tythe pe best pat is not sownd" in Cain's mind (94). He vows that he will "tythe pe werst and make no bost" (97). The rejection of Cain's tithe, as in the Chester play, is contextualized and rationalized as a response to Cain's poor attitude and negative behaviour, especially in contrast with that of his brother.

It is only after Abel's tithe is accepted and honoured that Cain first addresses Abel with the label of "brother": "herke abel brother what a-ray is pis?" (131). Cain questions Abel directly about the honour he has received while he himself has received none. In this play, Cain's anger is immediately directed towards Abel, and he makes no attempt to hide his contempt or his plans to slay his brother:

What pou stynkyng losel and is it so

\footnotetext{
${ }^{36}$ For an examination of potential audiences of the N-Town play, see Colin Fewer, "The 'Fygure' of the Market: The N-Town Cycle and East Anglian Lay Piety," Philological Quarterly 77, no. 2 (March 22, 1998): 117-47.
} 
doth God pe love and hatyht me

pou shalt be ded I shal be slo

pi Lord pi God pou shalt nevyr se

Tythyng more shalt pou nevyr do

Now pis boy is slayn and dede

Of hym I shal nevyr more han drede. (144-54)

Cain's speech reveals two significant aspects of his character. The first is his belief that his brother is his main source of competition. Whereas Abel, in speaking to their father, asked for advice so that both he and his brother could succeed, Cain believes the tithings to have been a form of competition. In his mind, God hates him because God loves Abel. Abel's tithes are accepted instead of Cain's. Secondly, not only does Cain explicitly categorize his failure as a result of Abel's success, but he also creates distance between himself and Abel with the label "this boy" rather than "brother" or even Abel's name in this instance. Abel uses the term brother freely and willingly. Cain, though he uses the term once, is quick to abandon it to rid himself of the fraternal bond which links the two characters.

However, Cain is unable to completely untie himself from the bonds of brotherhood, as God quickly reaffirms the relationship between the two men. God's first speech in this play is not to chastise Cain for his foul behaviour and disappointment in the rejection of his tithe, but is rather in response to the actual murder of Abel: "Caym come fforth and answere me / a-soyle my qwestyon anon ryght / thy brother Abel wher is now he?" (157-9). While Cain attempts to distance himself from Abel, seemingly glad to be 
rid of the other man, God does not allow Cain to forsake his fraternal duty. Once again, as seen in the other plays as well as Genesis, Cain challenges God, asking: "My brothers kepere ho made me / Syn whan was I his kepyng knyght?” (161-2). Cain specifically asks God when he became responsible for his brother, as it seems to him that it is only in response to fratricide that God demands fraternal loyalty. Cain's behaviour prompts God to put the obligations and loyalties one owes to a brother into words, as Abel is only missing after Cain slays him. The N-Town play reproduces this fact from Genesis, reminding the audience and readers that while Cain failed to control his emotions and to uphold the ideal bond of fraternity, they must do better.

\section{Towneley}

As seen in the chart above, the Towneley version of the Cain and Abel tale is the most expansive, at a total of 473 lines. ${ }^{37}$ There is one incomplete manuscript, which contains the entirety of the Towneley cycle: San Marino, California, Henry E. Huntington Library and Art Gallery, HM I. The manuscript is believed to have been copied in the last decades of the fifteenth century, even possibly at the beginning of the sixteenth. ${ }^{38}$ The Towneley cycle is often associated with the town of Wakefield based upon two rubric references to the town found within this manuscript. It has also been argued that, unlike the other cycles, many of the plays are the work of one author, referred to by scholars as

\footnotetext{
37 Not counting the entirety of the "Adam" play in the Chester cycle.

38 For more information on the manuscript, see Martin Stevens and A. C. Cawley's introduction in The Towneley Plays, Vol 1, EETS s.s. 13 (Oxford: Oxford University Press, 1994).
} 
the Wakefield master. ${ }^{39}$ The "Mactacio Abel" is the second pageant within this cycle and was performed by the Glovers, according to the manuscript notations. Several scholars have ruminated on whether the plays were actually performed or not. Happé points out that "the question of performance has been much debated. It does not seem likely that in the fifteenth century, at least, Wakefield was rich or populous enough to be able to support a cycle of the size presented in the manuscript." ${ }^{40}$ Stevens points out that "[i]t is a mistake to assume that the extant manuscripts were used as play texts for the performance. ${ }^{{ }^{41}}$ However, Happé also reminds us that "[ $[$ ]he Towneley manuscript is very ornate, as though it were intended for a presentation for the purpose of reading rather than for acting." ${ }^{42}$ Whether performed or read, the text of the Cain and Abel play is one which builds upon the lessons inherent to the original Cain and Abel story. Regardless of the actual usage of the text, the morals present within the play demonstrate the author's understanding of, and adherence to, the notion that governance and fraternity are connected within the tale.

Throughout the Towneley play, Cain's poor governance is amplified through his actions and attitude. This is partly done through Cain's treatment of not only his brother, but also his servant. Unique to the Towneley "Cain and Abel" is the character of Gracio, who opens the play with an address directly to the audience. He identifies himself as

\footnotetext{
39 This name was first attributed to the medieval author by Charles Mills Gayley in 1907. See Charles Mills Gayley, Plays of Our Forefathers and Some of the Traditions Upon Which they Were Founded (New York: Biblo and Tannen, 1907, rpt. 1968).

${ }^{40}$ Happé, 37.

${ }^{41}$ Stevens, 14.

42 Ibid..
} 
Cain's servant, while at the same time establishing the fact that at least some in the audience will relate to Cain:

Gedlyngys, I am a full grete wat.

A good yoman my master hat:

Full well ye all hym ken.

Begyn he with you for to stryfe,

Certys, than mon ye neuer thryfe:

Bot I trow, bi God on life,

Som of you ar his men. $(14-20)^{43}$

Garcio immediately points out that some in the audience know Cain well. This close association with the character is problematic from the beginning of the tale, as those in attendance already know the history of Cain. However, it becomes more problematic as Cain's behaviour worsens throughout the play. It begins with his treatment of his mare, complaining that the beast is "the warst mare / In plogh" that he ever had (34-5). Cain also slaps Garcio when the boy challenges Cain for not feeding the horses enough (50). Cain's first appearance on the stage is marked by violence. Whereas in Genesis, and the Chester and N-Town plays, Cain's violence arises only after his tithe is not accepted by God, here his character begins as both angry and cruel. The Towneley play, like the sermons, focuses on Cain's wrath as indicative of his character flaws.

Cain's abrupt and abrasive entrance is further problematized because it is immediately contrasted by Abel's entrance. Abel appears on the scene with a kind

\footnotetext{
43 All excerptions are taken from: "Mactacio Abel," in The Towneley Plays, eds. Martin Stevens and A. C.
} Crawley, EETS s.s. 13, vol. 1, 12-25 (Oxford: Oxford University Press, 1994). 
greeting: "God, as he both may and can, / Spede the, brother, and thi man" (59-60). Whereas Cain appears complaining about his own difficulties, Abel appears wishing both Cain and Garcio well. Cain's response is less than friendly as he exclaims, "Com kis myne ars!" (61). The animosity between Cain and Abel is not a result of Cain's perceived slight by God, but rather appears to be part of Cain's general behaviour and attitude. Cain's anger is evident in his treatment of Abel even before the brothers go to make an offering to God. His treatment of Abel does not improve, as throughout his early speeches he tells Abel to "kys the dwillis troute" (65). His evocation of the devil directly contrasts with Abel's wish for God to look well upon him. Cain's anger, demonstrated in his speech, is at odds with Abel's calm and meek demeanor. Cain's lack of self-control, and his inability to govern his emotions, makes him lash out at Abel, Garcio, and his horses, all before he even makes it to the altar to offer his tithe.

The contrast between Cain's behaviour and attitude and those of Abel is further amplified when Abel suggests that they go to make their sacrifices to God. In this play, Cain demonstrates his poor attitude before he even reaches the altar, as seen in his initial refusal to even consider tithing. Abel encourages Cain to come with him to tithe:

Bot, leif brother, here my sawe:

It is the custom of oure law.

All that wyrk as the wise

Shall worship God with sacrifice.

Gif we hym parte of oure fee,

Corn or catall wheder it be. (70-9) 
Abel's speech demonstrates not only his attitude towards God but also towards Cain. He views both of their sacrifices as necessary and equal. Neither is to be better than the other, as "corn or catall" are both acceptable as offerings. Abel wishes to tithe together, not to demonstrate his superiority to Cain but to honour God together, as brothers. Cain bristles at this, and challenges Abel by asking: "What gifys God the to rose hym so? / Me gifys he nought bot soro and wo" (97-98). Just as in the Chester version of the play, Cain's attitude towards tithing is done reluctantly, and even more so in this instance. Whereas in the Chester play Cain's mistake was wondering what reward he would receive for tithing, in the Towneley play, Cain does not see the need to tithe at all, feeling as if God has given him no reason to do so. Cain views his hardships as God's fault and does not acknowledge that everything he does have is because of God.

Not only is Cain's poor behaviour amplified, but so too is the role of fraternity. As the chart above demonstrates, the Towneley version of the Cain and Able tale expands the interactions between the two brothers more than either of the other versions examined here. Abel uses the term "brother" when addressing Cain a total of seventeen times in his twenty-five separate speaking parts, emphasizing the fraternal connection between them. Almost every time Abel speaks, he uses the term "brother" to address Cain. This makes Cain's violence against him all the more poignant as Abel reinforces their blood connection, and it is Abel's blood which will be spilled when Cain attacks him. Abel continually appeals to Cain to perform the ritual of tithing properly and with good heart. He calls upon Cain as "brother" and as "leif brother." Even though he could simply leave and tithe on his own, Abel wishes for them both to tithe, and asks Cain to sacrifice with him several times. For example, he says: "Com furth, brothere; we dwell full lang. / Gif 
wehym parte of oure fee" (75-76); "And therefor, brother, let vs weynd, / And first clens vs from the feynd / Or we make sacrifice;" (80-2); "Brother, as elders haue vs kend, / First should we tend with oure hend, / And to his loyfing sithen be brend" (103-5); "Leif brother, let vs be walkand; / I wold oure tend were profyrd." (108-9); Good brother, let vs weynd sone; / No longer here, I rede, we hone." (134-5). As seen in the N-Town play, Abel does not see his own tithe as a separate offering from Cain's. He believes that as brothers, they should tithe together. In the Towneley play, Abel must try to convince Cain to come with him to tithe at all:

Dere brother, hit were grete wonder

That I and thou shuld go in sonder;

Then wold oure fader haue grete ferly.

Ar we not brether, thou and I? (156-59)

Abel views the tithe as something they should do together specifically because they are brothers and views his own success as linked to Cain's. He sees their lives and their tithes as intertwined through the bond of fraternity which they share. Cain's response is telling, as he states: "No, bot cry on, cry, whyls the think good!" (160). Cain rejects the bond of fraternity between them, seeing Abel as a nuisance and tiring of his begging. Cain is not moved by the blood they share as brothers, and eventually agrees to tithe not because he accepts that Abel is right, but because he is tired of hearing Abel ask.

Notably, while Abel uses fraternal terms of address consistently throughout his speeches, Cain uses the term "brother" only once to refer directly to Abel in this play. ${ }^{44}$

\footnotetext{
${ }^{44}$ This discrepancy between using fraternal terms of address either with or about the brother in question will be contrasted in Chapter Five, exploring The Tale of Gamelyn. Within that text, we see the opposite,
} 
Cain, responding to Abel's plea that they go to tithe, states: "We! wherof should I ten, leif brothere?" (110). And while there are no stage directions or indications of how this line would be delivered, it is difficult to read it as anything but sarcastic. It immediately follows Abel's use of the exact term "leif brother" and nowhere in the speech does it suggest that Cain's anger and annoyance have abated. Rather, the line reads as if Cain is mocking Abel's insistent usage of the term. Cain's attitude and behaviour are contrasted with Abel's through the ways in which both brothers speak and the ways in which they use fraternal terms of address. Abel attempts to guide his brother's attitude towards one which will allow him to honour God. Cain uses his speech to mock and complain.

Cain's complaints do not end when Abel finally convinces him to tithe, as throughout the entire process Cain makes his displeasure known. In Genesis, there is no apparent reason given for the acceptance of Abel's offering and the rejection of Cain's, and as Nauta argues, the "rejection and acceptance are random, without reason or meaning, they make no sense." ${ }^{45}$ In the Towneley version of the play, however, it is abundantly clear why Cain's offering was rejected. Presented comically, Cain's hesitation to offer anything more than the worst of his yield is clearly the reason why his offering is outright rejected by God. As he prepares the tithe, he counts out each individual item, taking some back when he decides that they are too good for God (194-211; 249-58). He does not give freely, and his offering is clearly marked as subpar when compared to Abel's. Also significant is the fact that in this version, unlike in Genesis and the other plays, Cain makes Abel sacrifice first: "Ryse! Let me now, syn thou has done. / Lord of

\footnotetext{
as Johan will often call Gamelyn brother to gain his trust but will never refer to Gamelyn as brother when speaking to others.

45 Nauta, 66.
} 
heuen, thou here my boyne!” (184-5). Cain makes his offering specifically because Abel has done so. He rushes his brother to finish so that he might have his own turn. Cain gives in order to receive the same benefit and blessing as Abel. Cain's attitude and behaviour, seen after tithing in Genesis, are present throughout the whole of this version of the tale.

The Townely play also emphasizes Cain's envy of Abel's successful tithing, heightening Cain's view of Abel as a rival rather than as a brother. As mentioned, Cain refuses to tithe until Abel has done so, not wishing for his brother to receive God's blessing while he does not. He directly blames his failure on Abel's success when his own tithe will not light properly in offering:

Bot now, syn thou has teyndid thyne,

Now will I set fyr on myne.

We! out, haro! help to blaw!

It will not bren for me, I traw.

Com kys the dwill right in the ars!

For the it brens bot the wars.

I would that it were in thi throte. (275-91)

Cain immediately compares his own flame to Abel's and, in addition, insults his brother once again. His anger at the fact that his tithe does not burn properly is directed at Abel. This fact is immediately addressed by God who asks "Cam, whi art thou so rebell / Agans thy brother Abell?" (293-4). In the Towneley play, Cain's emotional response is directly tied to his anger towards his brother. In this version, Abel also addresses Cain's anger, 
asking "Brother, whi art thou so to me in ire?" (318). Abel calls into question Cain's behaviour towards him, especially as a brother. Evoking that relationship once again, Abel demands to know why Cain behaves so poorly towards his own brother. Abel wishes to know if he is truly to blame for the fact that his sacrifice was accepted while Cain's was not, to which Cain immediately replies "We, yei!" (325). Voiced here in a way we have not seen before is Cain's anger and envy towards his brother. He openly blames Abel for his own failing. His inability to control his own temper and behaviour becomes manifest in his treatment of his brother.

As is evident in both the Chester and the Towneley versions of the tale, the biblical story of Cain and Abel was expanded upon for the stage performances. Audiences witnessed first-hand the correlation between Cain's anger and fratricide. It is Cain's envy which drives him to see his own brother as a rival. Both Chester and Towneley plays amplify Cain's lack of self-governance, as his expectations and attitude towards tithing become more problematic than they appear to be in Genesis. Whether or not these scripts were performed exactly as written, it is evident that medieval playwrights saw the opportunity to amplify Cain's poor behaviour as a reason for his unsuccessful tithing. The plays demonstrate the devastating outcome of Cain's anger and envy as he turns to fratricide. By giving Abel a voice, his loyalty to Cain makes Cain's betrayal all the more troubling.

\section{Edward IV and the Duke of Clarence and Conclusions}

As noted in the opening of this chapter, while fratricide appears to have been a useful literary tool in the late medieval era, there are very few documented cases of actual 
fratricide within fifteenth-century court cases. Thus far, I have also been unable to discover any instance in the legal documents of a fraternal feud becoming violent enough to end in murder in late medieval England. In fact, the only example of a murder remotely related to fratricide in the fifteenth century I could discover is the execution of George Plantagenet, first Duke of Clarence, brother to Kings Edward IV and Richard III. In 1478, under the reign and rule of his brother Edward, George was executed on the charge of treason. This execution was not labeled as a fratricide either in the contemporary records or by historians since. Edward IV did not technically kill his own brother, but I would argue that it is akin to fratricide, as he gave the order which brought about George's death, and it represents exactly the kind of anxiety the literature of the fifteenth century demonstrated when it came to brothers and power. Brothers can be one's closest ally — in the case of George, he was, in fact, Edward's heir. However, the very nature of that position also meant that, in many ways, George was the one who had the most to gain from deposing Edward. In fact, Edward IV's execution of his own brother did not come without cause, as George had, on more than one occasion, taken part in a rebellion against his brother as king. He also aligned himself with another man who opposed Edward's rule when he married Isabel, the daughter of the Earl of Warwick. ${ }^{46}$

This contradiction between the concerns raised in literary works and the reality of lived life in the medieval period is also noted by André Crépin who states his astonishment when, considering fratricide's importance in Beowulf and other works, he

\footnotetext{
${ }^{46}$ For a detailed exploration of George's life and political actions, see Michael Hicks, False, Fleeting Perjur'd Clarence: George, Duke of Clarence, 1449-78, revised edition (Bangor, Gwynedd: Headstart History, 2012).
} 
was unable to locate any examples of actual fratricides in the High Middle Ages: "Je m'attendais donc à trouver des fratricides dans l'Angleterre du Haut Moyen Âge où abondent frères et sœurs de familles puissantes. Stupeur : je n’y ai repéré aucun cas de fratricide. ${ }^{97}$ In the search for historical fratricide, Crépin was able to locate only one possible example from the early medieval period: the assassination of King Edward (978 CE). After Edward's death, his brother Æthelred the Unready was crowned king. As Crépin points out: “on accusa Æthelred d'avoir fait tuer son frère Edward afin de lui prendre la couronne." ${ }^{48}$ However, Crépin highlights that the evidence we have does not prove this rumor to be true, and in fact, the negative reputation of Æthelred, which would support such an accusation, appears to have come into being only after this death. ${ }^{49}$ Without proof that Æthelred actually orchestrated the death of his brother, we cannot say that this event represents a real-life fratricide. ${ }^{50}$

Fratricide may have been an active concern in medieval literature, but there is no judicial evidence of a fratricide having occurred, with the execution of George being as close to an actual example I could find in the fifteenth century. Brothers may fight and feud, but did not appear to kill each other, at least not with their own hands. Yet, fratricide was present in the story of the very first Christian brothers, making brotherhood a relationship inherently fraught with dangerous potential. Medieval authors, preachers,

\footnotetext{
${ }^{47}$ André Crépin, "Le fratricide dans l'Angleterre du Haut Moyen Âge," in Frères et soeurs : les liens adelphiques dans l'Occident antique et médiéval: Actes du colloque de Limoges, 21 et 22 septembre 2006, eds. S. Cassagnes-Brouquet and M. Yvernault (Turnhout: Brepols Publishers, 2007), 183. 
and compilers of drama viewed the potential for fratricide as a useful tool through which to examine larger questions of familial relationships, obligations, and governance. The texts I have included in this dissertation, from Cain and Abel to The Tale of Gamelyn, allowed authors to examine the paradoxical positions of brothers as both closest kin and significant rivals for resources and power, whether metaphysical or otherwise. The story of Cain and Abel, used in sermons as a caution against anger and jealousy and presented on stage for both entertainment and instruction, demonstrates anxieties over fratricide and fraternity in the cultural imaginary which are seemingly at odds with the judicial actuality of the period. The paradoxical relationship between brothers as allies and rivals will be further explored in the next chapter, where I examine the breakdown of fraternity when the brothers Polymyte and Eteocles cannot rule side-by-side as leaders of Thebes. 


\section{Chapter Two: Siege of Thebes: Classical Origins}

As we have seen in the previous chapter, a brother may be one's closest kin but can also become one's biggest rival. In John Lydgate's Siege of Thebes, this contradictory relationship is pushed to its limits. Just as the story of Cain and Abel culminates in the ultimate betrayal of fraternity, the Siege ends with a double fratricide of two brothers: Polymyte and Eteocles. Rather than turn to the biblical Cain and Abel, Lydgate reimagines a story from classical history to explore issues of polity and governance. Whereas in the Cain and Abel story fratricide was used as a tool to examine issues of self-governance related to spirituality, the Siege focuses on self-governance as it relates to and impacts the political realm. Through the exploration of the relationship between these brothers, the sons of a king, the Siege presents the worst-case scenario of a clash between fraternity and governance, suggesting a correlation between corrupt governance and the rejection of brotherhood. In this chapter, I examine the way in the text focuses on key characters who are both brothers and rulers, and how their actions in one role are often reflected in their ability, worthiness, or reputation in the other. I argue that by engaging with the idea of fraternity and governance, the Siege presents the two as necessarily connected, yet imbued with the potential for dangerous conflict. In the Siege, Lydgate examines the larger political consequences of fraternal feuding when those involved are also in positions of governance over people and lands. His concept of good leadership is tied to one's ability and willingness to be a good brother; the refusal to be such a brother results in devastating consequences which extend beyond the brothers at the heart of the quarrel. 
Lydgate was one of the most prolific writers of the fifteenth century. ${ }^{1}$ Though some nineteenth and twentieth-century scholarship has dismissed him as "drivelling" ${ }^{2}$ or as a pale imitation of Chaucer, recent scholarship focuses on reigniting passion for the works of the Monk of Bury, a passion which was clearly present in fifteenth-century England, as evident by the vast number of surviving manuscripts containing his writings. The Siege of Thebes was evidently one of Lydgate's popular texts, as there are twentynine known extant manuscripts which include the Siege. Lydgate sets the telling of this story within the framework of Geoffrey Chaucer's The Canterbury Tales. ${ }^{3}$ Just as Chaucer imagines a character of himself as a pilgrim, Lydgate creates the persona of "Lydgate / Monk of Bery, ny3 fyfty zere of age" (I. 92-3), who tells the tale of Thebes as part of the storytelling game which Chaucer establishes for his pilgrims. The poem retells the story of Polymyte and Eteocles, the sons of King Oedipus through his incestuous marriage to his mother, Jocasta. Divided into three sections, plus a prologue, the tale relates the events of the Oedipus story and the eventual fall of Thebes at the hands of the two brothers. After the death of Oedipus, Eteocles and Polymyte both wish to rule Thebes, but they are unwilling to do so together. The lords convince them that each brother will rule for one year and then abdicate the throne, passing it onto the other brother at the end of the year. The brothers eventually agree to this, and Eteocles takes up the crown first while Polymyte goes into exile. While there, Polymyte meets Tydeus,

\footnotetext{
${ }^{1}$ As Derek Pearsall recounts, Lydgate composed almost 145000 lines in his lifetime.; Derek Pearsall, John Lydgate (London: Routledge \& Kegan Paul, 1970), 177.

2 Joseph Ritson, Bibliographia Poetica (London: C. Roworth, 1802), 87.

${ }^{3}$ All Siege of Thebes quotations are taken from John Lydgate, The Siege of Thebes, eds. Axel Erdmann and Eilert Ekwall, EETS e.s. 108 and 125, 2 vols. (London: Kegan Paul, Trench, Trübner \& Co, 1911 and 1930). I have omitted italicized expansions, as well as caesura and diacritical marks.
} 
with whom he forms a bond of chosen fraternity. These two men marry the daughters of Adrastus and, as such, are given new positions of governance in Agre. When a year has passed, Eteocles refuses to honour his promise to pass on the rule of Thebes to Polymyte. The latter then wages war against Eteocles, with the backing of Adrastus, Tydeus, and many other Greek lords. Polymyte and Eteocles ultimately meet in battle at the gates of Thebes, where they kill each other.

The framing of the Siege as a Canterbury tale has naturally led many scholars to compare Lydgate to Chaucer and the Siege of Thebes specifically to the "Knight's Tale."4 Whereas the "Knight's Tale" is the first story told on the way to Canterbury, the Siege is framed as the first story on the return journey. In addition, the Siege ends with the events which open the Knight's Tale. While the connection between these two texts has generated productive discussion, it has also meant that Lydgate's poem has often been viewed as an attempt to imitate Chaucer and has been judged according to the concerns of the "Knight's Tale." However, recent scholarship has begun to explore Lydgate's work on its own merit, breaking away from viewing Lydgate's writing as not only a poor imitation, but an imitation at all, of Chaucer's work. ${ }^{5}$ This chapter builds upon this movement and argues that even within Lydgate's own Canterbury tale, there is further

\footnotetext{
${ }^{4}$ For examples of the comparisons between the Siege of Thebes and the Knight's Tale see James Simpson, “'Dysemol daies and fatal houres': Lydgate's Destruction of Thebes and Chaucer's Knight's Tale," in The Long Fifteenth-Century: Essays for Douglas Gray, eds. Helen Cooper and Sally Mapstone, 15-30 (Oxford: Clarendon Press, 1997); A. C. Spearing, "Lydgate's Canterbury Tale: The Siege of Thebes and FifteenthCentury Chaucerianism," in Fifteenth-Century Studies: Recent Essays, ed. Robert Yeager, 333-364 (Hamden: Archon, 1984); and Rosamund S. Allen "The Siege of Thebes: Lydgate's Canterbury Tale," in Chaucer and Fifteenth-Century Poetry, eds. Julia Boffey and Janet Cowen, 122-42 (London: Kings College London, 1991).

5 Jacob Riyeff's recent article is one such study which argues against the "harsh portrayal of Lydgate" in previous scholarship. See Jacob Riyeff, "“Tynlvmyne”: The Laetabundus: John Lydgate as Benedictine Poet," JEGP 115, no. 3 (July 2016): 370.
} 
significance to unearth in the story. By exploring Lydgate's Siege beyond its connection to the "Knight's Tale," I show the way in which Lydgate presents fraternity as interconnected with governance. While Chaucer explores the conflict between fraternal and romantic love through the characters of Palamon and Arcite, Lydgate uses the characters of Polymyte and Eteocles to explore the correlation between fraternal disloyalty and poor governance.

The connection between fraternity and governance in the Siege is two-fold. The first link between these two concepts is perhaps the most obvious, in that three of the main characters, Polymyte, Eteocles, and Tydeus, are all brothers in some form or another and are all, at some point, in positions of governance. Polymyte and Eteocles's feud is presented as an exemplum of how poor fraternity can correlate with poor governance. The character of Tydeus is introduced to counteract this, and to demonstrate the proper behaviour of brothers, even if, and perhaps most significantly, the fraternity shared is a chosen one based on sworn oaths rather than an automatic relationship based on shared blood. It is through Polymyte, Tydeus, and Eteocles that Lydgate explicitly examines the connection between one's behaviour as a brother and one's behaviour as a ruler. In its concern with questions of rulership, the Siege is an example of the genre of medieval literature known as "mirrors for princes" or "advice for princes." This genre of advice literature, which has its origins in ancient Greek texts, was popular throughout the medieval period. In these texts, authors strove to create instructional examples for rulers to emulate in their own political careers. ${ }^{6}$ Lydgate's Siege offers insight into the ways in

\footnotetext{
${ }^{6}$ For more information on the genre, see Judith Ferster, Fictions of Advice: The Literature and Politics of Counsel in Late Medieval England (Philadelphia: University of Pennsylvania Press, 1996).
} 
which princes and kings should conduct themselves, both within their interpersonal relationships and in their political actions and commands. Lydgate utilizes failed fraternity to demonstrate the destructive potential of a ruler who cannot self-govern his own anger, jealousy, and overall emotions. A poor brother makes a poor ruler. The brotherhood of these two men is connected repeatedly to their position as leaders, and it is their willingness to learn how to be a better brother, or their refusal to do so, that ultimately guides the events which lead to the fall of Thebes and the death of both men.

The second connection between fraternity and governance within the Siege is the way in which Lydgate's presentation of what makes a good brother and leader is aligned with the teachings of the Benedictine order to which he belonged. ${ }^{7}$ It is evident that Lydgate does not merely retell a story of problematic brotherhood; he also develops his own model of idealized fraternity which is necessarily informed by his own lived monastic experience. Lydgate's use of a monk as the tale's narrator emphasizes the text's connection to the monastic tradition, as now the tale is both recorded and translated by a monk and, just as importantly, is told from the perspective of a monk. The model of fraternity found within the poem adheres to the recorded, if not practiced, monastic ideals of brotherhood as outlined in the Rule of St. Benedict. ${ }^{8}$ The way in which Lydgate's

\footnotetext{
${ }^{7}$ For examples of other works which explore the Benedictine connections within Lydgate's works, see Shannon Gayk, "Images of Pity: The Regulatory Aesthetics of John Lydgate's Religious Lyrics," Studies in the Age of Chaucer, 28 (2006), 175-203; Joseph Grossi, "Cloistered Lydgate, Commercial Scribe: British Library Harley 2255 Revisited," Medieval Studies, 72 (2010), 313-61; Mark Faulkner and W. H. E. Sweet, "The Autograph Hand of John Lydgate and a Manuscript from Bury St. Edmunds Abbey," Speculum 87, no. 3 (July 2012): 766-92; and Nicolas Heale, "John Lydgate, Monk of Bury St. Edmunds, as a Spiritual Director," in The Vocation of Service to God and Neighbour: Essays on the Interests, Involvements and Problems of Religious Communities and Their Members in Medieval Society, ed. Joan Greatrex, 59-71 (Turnhout: Brepols, 1998).

${ }^{8}$ All quotations from the Rule are taken from The Rule of Saint Benedict, ed. and trans. Bruce L. Venarde (Cambridge: Harvard University Press, 2011).
} 
presentation of fraternity aligns with the teachings of a Benedictine monastery will be examined throughout this chapter, probing the way in which the concerns about how to be a good brother while also being a good leader are present within the monastic organization as well. It is not difficult to imagine that both harmony and discord between individual brothers would contribute to the overall atmosphere of the monastery where they resided. Just as Eteocles's and Polymyte's feud has larger consequences for their kingdoms, feuding between Benedictine brothers could have disrupted a monastic goal of working together to live a life in service to God. The Benedictine doctrine focuses on education to promote self-growth and improvement in their spiritual journeys. Lydgate's text also engages with these hopes, connecting them to the political world of kings and armies to explore what is at stake when efforts to help others improve their self-control fail. In both Lydgate's Siege and a monastery, such as Bury St. Edmunds, the actions of a brother have ramifications for the governing polity.

Within the Siege, the focus on brothers is evident not only in the events of the text but also within the language of the text itself. Fraternal terms of address are used just over fifty times within the poem, with almost three quarters of the references to brothers being specifically in relation to Polymyte and Eteocles. Despite their shared blood, the brothers refuse to rule Thebes side by side. Lydgate explicitly states that the feud between Eteocles and Polymyte will lead to the destruction of Thebes, framing fraternal discord as responsible for the destruction of the whole of the city. Lydgate argues that the brothers are completely devoid "[o]f brotherhode the faithful alliaunce" and blames this broken alliance for "[f]ully worchyng into destruccioun / And Ruyne of this noble toun" (II. 1071-4). Lydgate condemns fraternal division by signaling the power of such a 
relationship to have larger political consequences, as lack of brotherly love not only leads to a divide between Eteocles and Polymyte, but to division between two kingdoms: Thebes and Argos. When, at the end of his ruling year, Eteocles refuses to give up the crown, Polymyte's attack on Thebes is supported by the king of Argos, who seeks to help Polymyte gain back his rightful position and wages war "vpon Thebës for polymytës sake" (III. 2570). The feud between two brothers becomes a feud between two kingdoms. Poor governance at the beginning of their rule means these brothers are at the heart of the destruction of Thebes. While the poem suggests the possibility of brotherly rehabilitation, it also demonstrates the catastrophic consequences when this rehabilitation fails.

\section{Fraternal Education}

The emphasis on self-improvement and training within the Siege of Thebes suggests that recalcitrant brothers can be educated to be better brothers and, through this, less destructive leaders. As argued later in this chapter, the potential for effective education in this matter is seen in Tydeus's successful rehabilitation of Polymyte, who learns to control his own behaviour and emotions by becoming a better brother. And while the text also investigates the impact of failed education, it nevertheless explores the importance of education as a potential tool for not only self-improvement, but also for successfully governing a polity. While Lydgate's poem addresses such political and public issues, his presentation and understanding of these issues are necessarily filtered through his experience as a member of a monastic fraternity, a filter which he makes explicit in the opening and framing of the Siege. Lydgate was not confined to the monastery and often travelled, though he would have spent a good portion of his life in 
the company of his monastic brethren. ${ }^{9}$ However, I am not suggesting that the Lydgate of the text is meant to be read as Lydgate the author without distinction. Even when maintaining biographical details, Lydgate-as-author constructs Lydgate-as-pilgrim. Derek Pearsall, in discussing the variety of Lydgate's works, argues that in each instance, "Lydgate is putting on a mask and that we should not interpret any of his works as "personal documents." ${ }^{10}$ Lee Patterson states that Lydgate "constructs his own identity as pious monk and advisor to the sovereign, in part through his self-representation within the Siege itself." ${ }^{11}$ Pilgrim-Lydgate may not be Author-Lydgate, but he is a monk and his values, opinions, and beliefs are necessarily created through the values, opinions, and beliefs of the monk-author who created him. As author, poet, and monk, Lydgate establishes his Siege as a text through which to examine the behaviour of brothers in power, and to consider how they might be better instructed in their roles to help improve both their control over their own behaviour as well as over the larger social, religious, and political worlds in which they rule.

In Lydgate's Siege, brothers are expected to either model ideal behaviour or to learn from such instruction should they not demonstrate fraternal loyalty themselves. This importance of education and a willingness to learn how to self-govern one's own behaviour are also key components of the Benedictine doctrine as found within the Benedictine Rule, the foundational text of the Benedictine order. Lydgate's own Testament highlights the importance of the guidance he received upon first entering the

\footnotetext{
${ }^{9}$ For an examination of the evidence of Lydgate's travel history see Pearsall, Lydgate, 27-31.

10 Ibid., 5.

${ }^{11}$ Lee Patterson, "Making Identities in Fifteenth-Century England: Henry V and John Lydgate," in New Historical Literary Studies: Essays on Reproducing Texts, Representing History, eds. Jeffrey N. Cox and Larry J. Reynolds (Princeton: Princeton New Jersey, 1993), 77.
} 
monastery and his introduction to the Rule: "His holy rewle was onto me rad, / And expounded in ful notable wyse, / by vertuous men, religious and sad." 12 Lydgate has specifically been taught the values of the monastery by "vertuous men." He has not simply read these virtues; he has seen them modeled by other members of the monastery. James G. Clark states that "[n]ovices were expected to learn as much from their active participation in the horarium as from the study of the codes in which it was enshrined."13 In order for novices to learn through participation, the senior monks would have necessarily had to act as role models for the novices to emulate. This necessity was recognized by monastic leaders, such as Bernard of Cluny who "advised novices that liturgical customs were learned best through what he termed "probatae experientiae" (demonstrated experience). ${ }^{14}$ Senior monks were expected to have mastered their own self-governance such that they might help instruct junior brothers. Jean Leclerqc emphasizes that there existed a difference between scholastic and monastic education, and highlights that "[i]n general, the monks did not acquire their religious formation in a school, under a scholastic, by means of the quaestio, but individually, under the guidance of an abbot, a spiritual father, through the reading of the Bible and the Fathers, within the liturgical framework of the monastic life." ${ }^{15}$ Leclercq expands briefly upon the difference

\footnotetext{
12 John Lydgate, "The Testament," in The Minor Poems of John Lydgate, ed. Henry Noble MacCracken, EETS 107 (London; New York: Kegan Paul, Trench, Trübner \& Co., 1910), 354.

13 James G. Clark, The Benedictines in the Middle Ages (Woodbridge: Boydell \& Brewer, 2011), 77. Clark quotes the customary of Eynsham, which states "regulam audiat, legat et relegate" ("Hear the Rule, read it, and reread it"), demonstrating the importance of both the Rule itself as well as the education and learning of novices. See The Customary of the Benedictine Abbey of Eynsham in Oxfordshire, ed. Antonia Gransden, Corpus Consuetudinum Monasticarum (Siegburg, Germany: Respublica-Verlag Franz Schmitt, 1963), 31.

14 Ibid.

15 Jean Leclercq, The Love of Learning and the Desire for God: A Study of Monastic Culture, trans. Catharine Misrahi (New York: Fordham University Press, 1961), 3.
} 
between "the monks' schools and the clerical schools," and argues that "it was often felt that [clerical] schools had many disadvantages and were hard to reconcile with monastic observances." ${ }^{16}$ St. Bernard of Clairvaux also draws a distinction between the education of monks and of those outside of the monastery. In the opening of the "Sermons on the Canticle of Canticles," he addresses his "brethren" and informs them that they "require instruction different from that which would suit people living in the world, and if not in matter, in manner, at least." ${ }^{17}$ The concern for an education specifically for the monastic student highlights the importance placed upon proper instruction within monasteries. Brothers were expected to receive education upon entering the monastery in how to govern themselves according to the rules of the monastery, and to pass on those lessons to those who later joined their brethren.

The Benedictine monks were not the only religious order which emphasized the importance of its members learning how to self-govern their emotions and behaviour through instruction from senior brothers. Caesarius of Heisterbach's Dialogus Miraculorum $(D M)$ is a thirteenth-century example from the Cistercian order which also focuses on issues of education. Caesarius frames the narrative exemplum as a dialogue between a senior monk and a novice. The individual books model the education of the novice, and represent cautionary tales concerning morality, sin, and the afterlife. As the editors of a collection exploring this text conclude, "the $D M$ was created to change and influence the lives of Cistercian monks, novices and lay brothers" and "explores the

\footnotetext{
${ }^{16}$ Ibid., 238.

${ }^{17}$ Bernard of Clairvaux, St. Bernard's Sermons on the Canticle of Canticles, trans. A Priest of Mount Melleray (Dublin: Browne and Nolan, 1920), 1.
} 
monk's existence from the moment when they enter the monastery to their death." 18 The emphasis on the education of new or soon-to-be monks is also evident in the description of the cloister of Durham, which states that "there was a fair great stall of wainscot where the Novices did sitt and learn" while the overseeing master of the novices "did sitt and teach the said Novices both forenoon and afternoon." 19 Additionally, the education of the novices is highlighted as one which was taken seriously, as there were "no strangers nor other persons suffered to molest or trouble any of the said Novices or Monkes in their Carrells, they being studying on their bookes within the Cloyster, for there was a Porter appointed to keep the Cloyster door." 20 This passage demonstrates that the novices were afforded an area of study which was set apart specifically for them. It also highlights the fact that the opportunity for both the monks and the novices to learn was viewed as important enough that a porter was specially assigned to prevent anyone from interrupting their study. The education of the monks was a key component of their lives within the monastic fraternity. ${ }^{21}$ This education went beyond learning religious scripture and extended to the improvement of self-governance among their brothers in their daily lives within the monastery.

\footnotetext{
18 See Caesarius of Heisterbach, The Dialogue on Miracles, trans. H. von E. Scott, and C.C. Swinton Bland (London, 1929); Victoria Sminova, Marie Anne Polo de Beaulieu, and Jacques Berloiz, Introduction in The Art of Cistercian Persuasion in the Middle Ages and Beyond: Caesarius of Heisterbach's Dialogue on Miracles and Its Reception (Boston: Brill, 2015), 14.

${ }^{19}$ Rites of Durham. Ed. J.T. Fowler (Durham: Publication for the Society by Andrews and Co, 1903.) 20 Ibid.

21 James G. Clark provides another example of the importance of education within the Benedictine monastery of St. Albans. Clark claims that during the Dissolution "an unusually large number of [the abbey's] manuscripts were recovered by the Crown and other collectors" and, as such, "it was recognized that from this one Benedictine house had emerged perhaps the most sustained tradition of learning and literacy production in the country." See James G. Clark, "Thomas Walsingham Reconsidered: Books and Learning at Late-Medieval St. Albans," Speculum 77, no. 3 (2002), 832.
} 


\section{Fraternity and Guidance in the Siege of Thebes}

Polymyte and Eteocles are the two figures who have the most to learn about both fraternity and good governance within the Siege, and it is through their willingness, or unwillingness, to change and learn over the course of the narrative that Lydgate demonstrates the importance of guidance when it comes to these two concepts. Their ability to learn to be good brothers is tied to their positions as leaders, as their inability to overcome their fraternal feud is at the heart of the war which sees the destruction of Thebes. These two brothers are rivals throughout the Siege, but their conflict is first foreshadowed in the description of the wedding of Oedipus and Jocasta. In the list of the wedding "guests," Lydgate lists “Cruel mars as eny Tygre wood, / Brennyng Ire of vnkyndë blood, / Fraternal hatë / depë sett the rote" (I.867-9). Lydgate introduces both fraternal hate and unkind blood before the birth of the brothers has even occurred. This is repeated after Oedipus has died, and his sons have thrown him into a pit: "Of Cursid stok cometh vnkynde blood" (I.1014). The introduction of the brothers as rulers is no different, as it begins with the demonstration of their hatred towards one another:

Whan Edippus buryed was and graue

How his sones the kyngdam for to haue, Among hem-silf be ful mortal hate

For the crownë gonnë to debate which of hem Iustly shal succede, And the Sceptre of the toune possede; Advertyng nought neither to right ne wronge, 
But eche of hem to make her partie stronge,

And his querele proudely to sustene" (II.1061-9)

Polymyte and Eteocles are introduced as brothers and potential leaders at the same time, while also being presented as full of "mortal hate" towards one another. The brothers' feud is directly tied to the rule of Thebes. They both wish to be crowned king, meaning that as brothers they are also each other's biggest source of competition. From the beginning of the Siege, Lydgate presents the long-reaching and problematic effects of fraternal feuding, as it becomes potentially dangerous for people other than the brothers involved. The fact that Etecoles and Polymyte are unable to govern their own anger and jealousy towards their brother is reflected in their (in)ability to govern the city of Thebes.

The condemnation of consanguine fraternal strife is often signified through Lydgate's use of the term "unkynde blood" to describe the feud between the consanguine brothers, and the term is repeated to emphasize the hate between these two men. When it is decided that Eteocles will rule first, Polymyte flees Thebes:

Beyng aferd to kepe the heghë way,

In his herte hauyng suspecioun

To his brother of malice and tresoun, lest he pursued thorgh fals vnkyndë blood

To haue hym ded for couëtise of good (II. 1154-58, emphasis mine). Meaning both "unnatural" and "hostile or violent in violation of a blood relationship," the term "unkynde blood" posits such a feud between brothers as one which is against 
nature. ${ }^{22}$ Lydgate specifically claims that this unnatural feud can be blamed for the ultimate destruction of Thebes. In her examination of Lydgate's use of "unkynde blood," Dominique Battles claims that the Siege “breaks with the medieval Theban tradition's most basic assumption: the belief in a pre-existing Theban condition, a genetic predisposition towards familial strife as the root of conflict." ${ }^{23}$ She argues that in Lydgate, "Edippus' crimes of parricide and incest originate with him" and are not inherited from his ancestors. ${ }^{24}$ She suggests that in the case of Eteocles and Polymyte, it is their "actions, not their ancestry" which "incriminate them" and that the "vnkynde blood,' therefore, applies to the generation of Eteocles and Polymyte alone, not to their ancestors." ${ }^{25}$ In agreement with Battle's argument, I argue that the feud between the brothers is not the fault of predetermination and, instead, is specifically presented by Lydgate as a choice they make. The feud cannot be excused as fate and the "unkynde blood," rather than being excused as a cause of their division, is considered a consequence of their failure to value a crucial relationship. Rather than a condemnation of fraternal strife and dissonance coming after the event of fratricide, as seen in Cain and Abel, in this case, the warning against brotherly feud is at the forefront of the narrative. The breaking of a fraternal bond is presented as unnatural before the physical fighting begins. Lydgate presents fraternal conflict as an ignoble, unnatural, and specifically chosen character trait which has far-reaching consequences. Unlike Cain, whose sins of

\footnotetext{
${ }^{22}$ Middle English Dictionary, eds. Hans Kurath, Sherman M. Kuhn et al. (Ann Arbor, MI: University of Michigan Press, 1952-), s.v. unkynde. http://quod.lib.umich.edu/m/med/.

${ }^{23}$ Dominique Battles, Medieval Tradition of Thebes: History and Narrative in the OF Roman de Thèbes, Boccaccio, Chaucer, and Lydgate (New York: Routledge, 2004), 145.

24 Ibid., 158.

25 Ibid., 160, 168.
} 
envy and pride are reflected in his fratricidal murder of Abel, the characters in the Siege are given the opportunity to redeem those sins, suggesting that self-governance can triumph over envy and pride through human will, training, and guidance.

The failed self-governance of Eteocles and Polymyte, demonstrated through their fraternal feuding, is contrasted with the behaviour and self-control of Tydeus. Polymyte, having gone into exile in Agre, takes shelter from the rain underneath a porch. When Tydeus, also searching for shelter, attempts to share the space, Polymyte refuses. After being awoken by Tydeus's arrival, Polymyte immediately goes on the defence, questioning the other man: "Of verrey Ire vpon his hors he stert, / And cruelly gan tydingës enquere" (II.1308-9). Just as anger and selfishness informed his relationship with Eteocles, ire influences Polymyte's reaction to Tydeus's simple request to share shelter. Polymyte displays a complete lack of self-control over his anger, refusing to share the space with another simply because he found it first and has claimed it as his own (II. 1326-28). Just as Polymyte was unwilling to share the rule of Thebes with Eteocles, his consanguine brother, he is also unwilling to share shelter with Tydeus. He cannot control his own tendency towards jealousy, seeking to protect what he believes to be his and refusing to share lest it be taken away from him. Polymyte's behaviours towards his brother and Tydeus are linked with his greed for power and domination, even over something as small as a porch which he technically has no right to control. Polymyte's anger and selfishness cause him to hoard the safety of shelter for himself, even when sharing the space would bring no harm to him and would benefit another. $\mathrm{He}$ seeks to control the space entirely. His anger and paranoia, which at the moment he does not control, are manifested in his attempt to rule over the physical space. 
When Polymyte and Tydeus fight, it is specifically because of Polymyte's inability to control his jealousy and his anger, much like the murder of Abel was a result of Cain's inability to govern those same emotions. Lydgate emphasizes the lack of selfgovernance that Polymyte possesses in this moment, and directly contrasts this with Tydeus's willpower to remain calm even in the face of the other's ire. While Polymyte speaks "of malys," Tydeus speaks "faire" (II. 1323; II. 1339). Tydeus responds to Polymyte's anger "in ful humble wise, / [and] answerd ageyn of verrey gentillesse" (II. 1312-13). We are informed that "ay the morë Tydeus spak faire, / Polymytë was froward and contrayre" (II.1339-40). Polymyte's greed and surly behaviour are counteracted by Tydeus's courtesy, a fact Lydgate emphasizes but which is not present in one of his major sources, the French Roman de Thèbes. ${ }^{26}$ Lydgate's text repeatedly attributes the feud between Polymyte and Tydeus to Polymyte's poor attitude and his unwillingness to show compassion to Tydeus. In the French version of the tale, the narrator contextualizes their fighting as at least partly due to their unfamiliarity with one another. As Elizabeth Hubble argues, the Roman de Thèbes "states that had they [Polymyte and Tydeus] been introduced, they would not have fought." ${ }^{27}$ In the Roman de Thèbes, the feud between Polymyte and Tydeus could have been avoided if they had been informed of one another's titles and positions. Lydgate does not provide the reader with this statement but, instead, implies that the feud is primarily caused by Polymyte's temper. Polymyte

\footnotetext{
${ }^{26}$ Le Roman de Thèbes, Lettres Gothiques, ed. Francine Mora-Lebrun, Lettres gothiques (Paris: Librairie générale française, 1995), edition of manuscript S (London, British Library, Add. 34114), II. 768-805. Translated in The Romance of Thebes: Roman de Thèbes, trans. Joan M. Ferrante and Robert W. Hanning (Tempe, AZ: Arizona Centre for Medieval and Renaissance Studies, 2018).

27 Elizabeth Hubble, "Par fiance bien tenir: Medieval Same-Sex Chosen Kinship and Sworn Brotherhood in the Roman de Thèbes," Medieval Feminist Forum 49, no. 1 (2013), 8; Roman de Thèbes, II. 816-19.
} 
continues to oppose Tydeus, and the two engage in combat (II. 1351-55). Polymyte's anger and greed lead to a dispute which could have theoretically ended with the loss of one or both of their lives. In contrast, Tydeus's behaviour is presented as exemplary, even when he is forced to engage in combat with Polymyte.

It is specifically through Tydeus's exemplary behaviour that Polymyte undergos a shift in his character, a shift which is displayed through his eventual swearing of a fraternal bond with Tydeus. Their duel is interrupted by King Adrastus, who ends the dispute by taking away their swords and pointing out the folly of their actions while encouraging them to be reconciled with one another (II. 1375-86). The narrator confirms that the resulting companionship between Tydeus and Polymyte is true and genuine and is, most significantly for my argument, based upon a bond of fraternity, not mere friendship:

that euer after, I dar afferme it wel, Eche was to other trew as eny stele During her lif both in word and dede vnder a knottë bounde of broperhede. (II. 1449-52) Tydeus's behaviour and self-governance become a model for Polymyte to emulate, and Polymyte's success in learning how to control his own emotions and behaviour is marked by the formation of a bond of fraternity between the characters. The focus on fraternity, rather than just companionship, is an alteration Lydgate makes to the source tale. In the Roman de Thèbes, Adrastus urges the two men to be sworn friends and companions, but 
no mention is made of them becoming as brothers to one another. ${ }^{28}$ Polymyte, at the urging of Adrastus and through the example of Tydeus, begins to display an understanding of the value of fraternity. He has developed a bond of chosen fraternity with Tydeus, willing to honour the obligations and duties of that bond, in contrast to his hatred and distrust of his own consanguine brother at the beginning of the tale.

The fraternity of Polymyte and Tydeus, which results in Polymyte's improved self-governance, is quickly linked to the capacity and worthiness of these men to hold positions of political governance. Polymyte and Tydeus are rewarded with political positions of power immediately following the swearing of their new bond of brotherhood. They have successfully self-governed their behaviour and emotions, a fact represented in their willingness to be bonded together as brothers. The microcosm of human selfgovernance becomes a basis for the macrocosm of political governance when Adrastus vows to marry his daughters to the two men, and offers them governance over his lands:

Therfor ze shal han possessioun, Duryng my lyf of half this Regioun, Forthwith in hond and hool after my day. Ther is no man that therto shal sey nay. And sothly after whan that I am graue, Eche of zow shal his party haue Of this kyngdam, as I haue provided; This to seyn it shal be devyded

\footnotetext{
28 II. 956-59. The text specifically highlights the fact that no other friends, not even Patroclus and Achilles, were better friends (960-3). The focus in the French source of the Siege, then, is on friendship, rather than brotherhood.
} 
A-twen zow two, euerich to be crowned,

3oure pourparties be equtyè compowned

So egally in euery mannys sight

That ech of jow reioysë his ryght. (II.1595-606)

Polymyte and Tydeus, now brothers through marriage as well as through oath, are rewarded immediately following the formation of this new bond with positions of power. Polymyte is given the opportunity to prove himself not only a loyal brother but also a good leader in his new position in Adrastus's lands.

Notably, the acceptance and reply of both Tydeus and Polymyte directly contrasts Eteocles's and Polymyte's earlier responses to the death of their father, particularly their argument over who would rule Thebes, as seen above. It is Tydeus who is the first to accept Adrastus's offer, modeling for Polymyte proper behaviour and intentions:

And for his parte seide he wolde assente

Fully of hertë, neuere to repente,

To all that euer the kyng hap sayd.

And Polymyte was also wel apayd. (II. 1633-36)

Whereas both Eteocles and Polymyte originally think only of themselves, not wishing to compromise or share the land and right to rule with a brother, Tydeus's example has helped Polymyte learn the value of fraternity. Etecoles and Polymyte were initially motivated by greed and anger, seeing their brother's equal right to rule as a threat to their own position. In contrast, Polymyte's willingness to share his power and land with Tydeus demonstrates the learned behaviour of proper fraternity and emotional selfgovernance, as a result of the influence and instruction of Tydeus and Adrastus. Polymyte 
displays his willingness to share a kingdom with the man with whom he had originally failed to share a porch.

Education of and for brothers, such as that demonstrated by Tydeus or Polymyte in this instance, is one of the key components of the Benedictine Rule. Examining the $B R$ allows us to better understand the types of ideas at play in the re-education and the remodeling of fraternity which occurs between Polymyte and Tydeus in the Siege. According to the Rule, modeling behaviour in addition to teaching it is especially necessary to instruct those who are not adhering to acceptable social behaviours for monitoring and governing their own emotions and actions. In addressing the role of the abbot in the monastery, the Rule specifically highlights the importance of not only teaching but also modelling good behaviour:

Ergo cum aliquis suscipit nomen abbatis, dupplici debet doctrina suis praeesse discipulis. Id est, omnia bona et sancta factis amplius quam verbis ostendat, ut capacibus discipulis mandata Domini verbis proponere, duris corde vero et simplicioribus factis suis divina praecepta monstrare. (Therefore, when anyone takes up the name of abbot, he must lead his disciples with twofold teaching, that is, he should show all good and holy things in deeds more than words, setting out God's commandments verbally for receptive disciples, but teaching the hard-hearted and less intelligent the divine precepts by his example. $)^{29}$

As the leader of the monastic community, the abbot is meant to serve as a role model for the other brothers to emulate. This is further emphasized when the Rule highlights the

\footnotetext{
${ }^{29}$ Rule 2.11-12.
} 
fact that the abbot must focus his attention on the brothers who are misbehaving in order to correct their behaviour and provide them with the opportunity to learn from their mistakes: "Omni sollicitundine curam great abbas circa delinquentes fratres, quia non est opus sanis medicus sed male habentibus [Matthew 9.12]" (The abbot should care for brothers who have behaved wrongly with the utmost concern because "it is not the healthy but the sick who need a physician"). ${ }^{30}$ The necessity of modeling behaviour is again recommended in the form of a Benedictine sermon from Worcester, mostly likely directed at an audience of monastic brethren: "Qui nescit predicare verbis predicet operibus / Citius credunt homines operi quam sermoni / Quia cepit iesus facere et docere" (He who does not know how to preach in words let him preach by example. Men are more apt to give credence to deeds than to words, for Jesus undertook both to act and to teach). ${ }^{31}$ The training of novice monks in a monastery requires senior monks and abbots to demonstrate and model the required behaviour. Likewise, Tydeus does not tell Polymyte how to be a good brother but rather shows him through his own actions. It is Tydeus's own self-governance which becomes a model for Polymyte to follow.

The Siege uses fraternity within the framework of the genre of advice for princes to emphasize the importance of self-governance in the exercise of political authority. Fraternal love becomes an example of how to exhibit self-governance and to maintain control over one's emotions when in key positions of rulership. Tydeus demonstrates self-governance and control in his interactions with Polymyte, and he attempts to do the

\footnotetext{
${ }^{30}$ Rule 27.1.

${ }^{31}$ Worcester Cathedral, MS F.10, fol. 138r, quoted and translated by Jean Greatrex in "Benedictine Sermons: Preparation and Practice in the English Monastic Cathedral Cloisters," Medieval Monastic Preaching, Ed. Carolyn A. Muessig (Leiden; Boston; Koln, 1998), 277.
} 
same for Eteocles. When the year of Polymyte's exile comes to an end, Tydeus ventures to Thebes in Polymyte's place to ensure that Eteocles will cede the throne to his brother, as per their original agreement. When it becomes evident to Tydeus that Eteocles does not adhere to any bond of brotherhood and is continuing to be ruled by his own greed and anger, Tydeus attempts to model for Eteocles how brothers are meant to behave towards one another. He openly states that he has come "from Polymyte his ownë brodere dere" (II.1899). The phrase "ownë brodere dere" can be read in two ways. Tydeus could be stating that he has come to Thebes for the sake of his chosen brother; he could also be stating that he has come on behalf of Eteocles's brother, emphasizing the relationship which Eteocles does not honour. The first is an example to Eteocles of how one should honour the bond of loyalty to a brother, while the second is a reminder to Eteocles that he should remember the fraternal bond he and Polymyte share. The ambiguity allows for either, or, more significantly, both. Tydeus, though not a consanguine brother, demonstrates more brotherly affection towards Polymyte than Eteocles has or will. Tydeus demonstrates to Etecoles how someone in control of their emotions and behaviour would never forget the bond shared with a brother.

Tydeus's request that Eteocles put aside his own anger and greed is not only about becoming a better brother but about becoming a better ruler as well. Tydeus directly correlates Eteocle's behaviour towards Polymyte with his capacity to rule Thebes: "And thenketh eke how that ze ar sworn / zour oth to kepe and make no tarying, / Holy aduerting lich a prudent kyng” (II. 1938-40). He continues, reminding Eteocles that keeping his word will earn him a good reputation beyond even the confines of the court: "Than wol al Grecë preise and magnyfie / zoure hegh renoun and may sey non other / But 
ze han quytt zou Iustly to zour brother" (II.1950-2). Eteocles's actions as a brother, in Tydeus's opinion, reflect on his reputation as a ruler. Even when Eteocles does not immediately react to Tydeus's appeal to think of his "brodere dere," Tydeus does not respond with outward threats of violence, demonstrating once again his own self-control over his emotions. Instead, he attempts to educate Eteocles about why the latter should honour his bond of brotherhood, as it is a sign of noble nature and even good kingship. Tydeus attempts to reason with Eteocles by explaining why he should relinquish the crown of Thebes:

Quyteth zour-silf Iustly of zour trouthe Vnto zoure brother avoyding this Cytè And lat hym regnen in his Ryaltè The croune of Thebes a zeer to occupie. (II. 1946-49) Tydeus encourages Etecoles to prove himself "true" by upholding the vow he made to his brother. Tydeus attempts to instruct Eteocles even after the latter has failed the first test of fraternity by refusing to cede his throne to his brother. Tydeus encourages Eteocles to be a good king by governing his own behaviour and adhering to the promises he made. In order to be an effective and prosperous ruler, Eteocles must learn to control his own emotions. In upholding interpersonal promises, he would demonstrate that he is a just and lawful ruler.

A similar attitude towards the importance of teaching self-governance to those in positions of power is found within the Benedictine model of discipline, which emphasizes the necessity of progressively increasing consequences when a monk fails to achieve good self-governance, rather than immediately condemning the first failure: 
Si quis frater contumax aut inoboediens aut superbus aut murmurans vel in aliquo contrarius existens sanctae regulae et praeceptis seniorum suorum contemtor repertus fuerit, hic secundum Domini nostri praeceptum ammoneatur semel et secondo secrete a senioribus suis. Si non emendaverit, obiurgetur publice coram omnibus. Si vero neque sic correxerit, si intelligit quails poena sit, excommunicationi subiaceat. (If any brother is found to be stubborn, disobedient, arrogant, a grumbler, or in any way opposed to the holy Rule and contemptuous of the teaching of elders, he should be privately reprimanded by his seniors once and then a second time, according to the teaching of Our Lord. If he does not improve, he should be scolded publicly, in everyone's presence. Should he despite that not correct his ways, he should undergo excommunication if he understands the nature of the punishment.) ${ }^{32}$

The Rule insists upon education and guidance, rather than punishment, as the first and preferred method for handling unwanted behaviour from monks within the monastery. The authority figure must demonstrate his own self-control and not be ruled by his emotions when disciplining misbehaving brothers. Correction is about helping the brothers learn to govern their behaviour within the monastery. Infractions against the rules of the community are graded by degrees and by occasions. Brothers are given several opportunities to correct their behaviour before the drastic measure of excommunication is invoked. Even when excommunication is recommended, there are various levels of severity appropriate to the degree of misbehaviour, beginning with

\footnotetext{
${ }^{32}$ Rule 23.1-4.
} 
excommunication from the common table, which denies the brother the fellowship of his community while taking his meals. ${ }^{33}$ These measures are temporary, meant to be imposed as brief punishments until the brother earns his place back in the community. Instruction is a tool for helping monastic brothers learn to govern themselves according to their Christian doctrine so that they are respected members of the fraternity in which they live.

Tydeus acts as a peer, not an authority figure as he attempts to correct Eteocles's behaviour so that Eteocles, too, might become a better brother and a better ruler. This attempt to appeal to Eteocles as an equal in order to influence his behaviour mirrors the instruction found within the Rule, pertaining to obedience of brothers to one another:

Oboedientiae bonum non solum abbati exhibendum est ab omnibus, sed etiam sibi invicem ita oboediant fratres, scientes per hanc oboedientiae viam se ituros ad Deum. .... Quod si quis contentiosus reperitur, corripiatur.

(The goodness of obedience is to be shown by all, not just to the abbot, but the brothers should similarly obey each other, knowing that they will approach God by this path of obedience... If someone is discovered to be resisting, he should be rebuked. $)^{34}$

There is no mention of the abbot as the disciplinarian in this chapter of the Rule, and it appears that brothers are encouraged to correct each other when unacceptable behaviour is displayed. Tydeus attempts to guide Eteocles's behaviour not through a position of authority, but through a position of mutual leadership. In fact, he attempts to emphasize

\footnotetext{
${ }^{33}$ Rule 24.1-3.

${ }^{34}$ Rule 71.1-5.
} 
the connection between loyal fraternity and displays of good kingship to convince Eteocles that maintaining his oath to Polymtye would benefit his own position of power.

Previous scholarship has recognized Tydeus's plea to Eteocles as an example of advice giving within the Siege. ${ }^{35}$ The ongoing counsel in the Siege, which Polymyte adopts and Eteocles ignores, is exactly the reason this text fits within the genre of "mirror for princes." However, what has been overlooked in examining the text as instruction for rulers is the fact that Tydeus's advice to Eteocles is not only concerned with good kingship, but also explicitly with fraternity. Tydeus specifically connects Eteocles's reputation as a ruler to his behaviour as a brother, guiding him as a fellow brother and a fellow ruler. Tydeus does not need to be in a position of authority over Eteocles to correct his behaviour in this instance. In fact, it is specifically their equal position as brothers to Polymyte that leads Tydeus to attempt to educate Eteocles in proper brotherly conduct.

The appropriateness of Tydeus as a guide and a role model of acceptable fraternal behaviour is not without contention. Tydeus's presentation as a valiant knight in the Old French source for the Siege is a departure from its own classical source. As Hubble identifies, the "monstrous Tydeus of antiquity is replaced with a paragon of a certain brand of medieval masculinity that Thèbes is privileging. The Old French author rewrote the character of Tydeus as a worthy brother-in-arms." ${ }^{36}$ Lydgate follows in this tradition, displaying Tydeus as a paragon of knightly behaviour and brotherly loyalty. However,

\footnotetext{
${ }^{35}$ See for example, Scott-Morgan Straker who identifies the importance of advice such as this in the Siege, arguing that "the didactic content of Lydgate's poem" was heavily concerned with "the giving and taking of counsel". Scott-Morgan Straker, "Deference and Difference: Lydgate, Chaucer, and the Siege of Thebes," Review of English Studies: A Quarterly Journal of English Literature and the English Language 52, no. 205 (2001): 8.

${ }^{36}$ Hubble, 14.
} 
Tydeus's own relationship with his consanguine brother is complicated and problematic. Tydeus is introduced as a prince of Caledonia who "out of that Regioun /Exilëd was for he his brother sclowe" (II 1270-1). However, the death of Menalippe is emphasized as a hunting accident:

For on a day as they on huntyng wente

In a forest for herte and for hynde

So as he stod vnder a grenë lynde, And Casuelly lete his Arow Slippe, he slough his broder called Menalippe (II. 1274-78)

Tydeus has committed fratricide, the ultimate betrayal of fraternal loyalty, but the murder is portrayed as accidental, which diminishes the blame that can be placed upon Tydeus. As Carolyn Larrington observes, "Lydgate's source, the Prose Roman de Thèbes, reiterates the phrase par grand mescheance at this point, insisting that Fortune had caused the death of Tydeus's brother." ${ }^{37}$ Larrington also argues that "Lydgate's narration nevertheless retains a significant ambiguity with regard to intention. In the Thebiad, impelled by the horror of his act, Tydeus flees his own kingdom; in Lydgate (though not the Prose Roman) he is exiled as punishment." ${ }^{38}$ However, Lydgate's text specifically states that "thorgh mortal sort his honde was begyled" (II 1279). Tydeus is not an ignoble character, though his accidental fratricide is a potential flaw, and he serves his sentence in exile for this, accepting the terms of his punishment. Tydeus's own involvement in fratricide is not a result of his lack of self-governance, but of fate. It is one example of the

${ }^{37}$ Carolyn Larrington, Brothers and Sisters in Medieval European Literature (York: York Medieval Press, 2015), 112.

38 Ibid., 112-13. 
fact that fraternity and fratricide may be inherently interlinked, and no matter what the intentions of the characters, it cannot always be avoided. ${ }^{39}$ Tydeus is placed in a position in which his brother, being close to him in a physical sense, becomes an unintended target for Tydeus's arrow.

Tydeus redeems his prior actions, accidental though they may have been, through his unwavering adherence to the oath of fraternity he makes to Polymyte-specifically in his attempts to become a role model and instructor of good fraternal behaviour for both Polymyte and Eteocles alike. In the case of Eteocles, his treatment of and attitude towards Polymyte are directly connected to his position and his ability as a ruler of Thebes, and both are criticized when he fails to accept Tydeus's instruction and guidance. Unlike Polymyte, who has demonstrated a shift in his attitude towards fraternity, Eteocles maintains his obstinate position. He refuses to place any value on the bond of blood he shares with his brother. Notably, Eteocles also expects the same sort of duplicity and malice from Polymyte as he himself exhibits. Upon learning of Polymyte's marriage and new lands, Eteocles immediately fears the worst, assuming Polymyte "wold vpon hym a newë werrë make" unless Eteocles "At tymë sette delyuerëd the toun / to his broder by bond of oth I-sworn" (II.1692-5). He believes that Polymyte would treat him with the same malice as he himself exhibits towards Polymyte and refuses to acknowledge that there is a benefit to upholding fraternal loyalty by conceding his position as king of Thebes.

\footnotetext{
${ }^{39}$ Accidental fratricide will be further explored in Chapter Four when I examine the double fratricide of Balin and Balan in Sir Thomas Malory's Le Morte Darthur.
} 
Tydeus is unsuccessful in his appeals to Eteocles's honour. Eteocles refuses to accept the guidance and advice of Tydeus, proving that he continues to lack self-control over his own anger and jealousy. That lack of self-control is mirrored in his poor governance as the King of Thebes. He refuses to denounce his fraternal feud and hatred of Polymyte, even at the risk of Thebes and its people, and vows that he will never agree to give up his rule to Polymyte:

That his hert shal neuer lyve in rest,

But in sorowe and in a maner drede,

Tyl his brother outrely be dede;

That he in Thebës in his Royal sete

Myght allonë regnën in quiete;

he mente hym-silf shortly, and non other,

Vnperturbed of Polymyte his brother. (II.1708-14)

Eteocles explicitly informs his lords that he will refuse to cede the crown to Polymyte, going so far as to say he would prefer Polymyte's death to his succession to the kingship of Thebes. This statement is an indication that Eteocles would also rather go to war, risking both lives and land to prevent his brother from ever coming into power. His rejection of fraternity because of his own lack of self-governance becomes a catalyst for war, which will have ramifications for the polity and not just the individual brothers at the heart of the feud. The war that follows the failure of Tydeus to help Eteocles learn self-governance and to appreciate fraternity is a representation of the potential danger that any kingdom would face should rulers allow themselves to be governed by greed and anger. Tydeus attempts to use fraternal love as a tool to guide Eteocles as a ruler, and the 
failure of Eteocles to accept this guidance allows Lydgate to explore what the consequences might be for a nation when their ruler refuses to reflect on his own behaviour and emotions.

Lydgate also explores the way in which fraternity, and the expectation of brotherly love, might be manipulated by those who seek to use such relationships for their singular gain. Within the Siege, Eteocles significantly attempts to manipulate both primogeniture laws as well as the expectation of fraternal loyalty for his own benefit. The first is evident early in the text, when Eteocles provides his reasoning that he should rule Thebes simply because he is the elder of the brothers:

But for his part this Ethiocles

Aleggë gan that he was first yborn;

For which he oght of resoun go to-forn

In the Citè to be crownëd kyng,

Sith be lawë ther was no lettyng.

For vnto hym longeth the heritage

Be discent and be title of age. (II.1084-90)

Eteocles argues that it is his right to rule because of the laws of primogeniture. ${ }^{40} \mathrm{He}$ attempts to utilize this presumed superior position within the fraternal relationship as a reason why he should solely inherit his father's land and title. Polymyte is not happy with this explanation, arguing that "Reson was non that he shuld haue alle / Regaly and domynacioun, / And the lordship hooly of the toun" (II.1094-6). Polymyte does not accept that primogeniture is reason enough for Eteocles to be given the crown of Thebes.

\footnotetext{
40 The expectation and manipulation of primogeniture will be further examined in Chapter Five.
} 
Eteocles uses a legal construct of inheritance which is necessary precisely because brothers are natural rivals for the goods and lands of their parents. Primogeniture, in its very nature, reflects the inherent conflict within fraternity, and Eteocles uses this to claim his own right to rule ahead of his brother.

Eteocles also attempts to manipulate the expected fraternal behaviour, which Tydeus suggests is necessary to be a good ruler, to criticize Polymyte's behaviour towards him, painting himself as the victim of the fraternal feud. In response to Tydeus's advice that he adhere to the oath he gave to Polymyte, Eteocles challenges Polymyte's behaviour as unbrotherly:

"I haue gret mervaile" quod he, "in my thoght

Of the massagë which that thow hast broght,

That my brother as thow hast expownyd,

Desyreth so in Thebës to be crownyd, Havynge reward to the habundance, The grete plentè and the suffisaunce That he hath nowe with the kyng of Arge:

Fully trustyng 3if I haddë nede

To his helpë, that with-outë drede

lik a brother than I shuld hym fynde

To meward feithful, trewe, and kynde:

It were no token as of brotherhede, 
But a signë rather of hatrede,

To interruptë my possessioun

Of this litil porë Regioun.” (II.1965-92)

Eteocles attempts to paint Polymyte as the one who is acting unbrotherly or in a fashion which denies fraternal loyalty. Based upon his belief that Polymyte is being unfair to him, Eteocles refuses to relinquish the throne. He uses this perceived injustice as evidence for his right to maintain his position as king in Thebes and informs Tydeus that Polymyte "shal not be title of no bond, / Reioysse in Thebës half a foot of londe" (II.2005-6). Eteocles, driven by his own greed and jealousy, attempts to use the fraternal obligations with which Tydeus has charged him to rationalize his right to maintain the rule of Thebes. He twists Tydeus's words to demonstrate how, in his opinion, Polymyte is being unfair to him. Eteocles does not uphold fraternal obligations as an ideal because he believes in their importance, but rather because he believes he can manipulate them for his own benefit.

The narrative warns against such deception, significantly linking Eteocles's falseness towards his brother to his reputation as a ruler. Tydeus himself warns Eteocles that his animosity towards his brother will lead to war:

Alle Grekës londe shal ypon the ryse,

To ben avenged and manly to redresse

The gret vntrouth and the hegh falsnesse

Which that thow hast ageyn thy brother wroght. (II.2053-6)

The correlation between fraternal feuding and political war is made explicit. Prior to this moment, Lydgate has already warned his audience that: 
Chaunge of word or mutabilitè

fraude or deceyte or vnstabilitè

Shuld in a kyng han domynacioun

To causen after his destruccioun.” (II. 1749-52)

These statements accentuate the fact that Eteocles's dishonouring of a vow made to his brother will help bring about the fall of all of Thebes. We are told specifically to "thenk how Thebës with his wallës olde / Distroiëd was platly this no les, / For doublenesse of Ethiocles" (II.1776-8). Jocasta also warns Eteocles about his behaviour, and once against specifically links his position as a king to his behaviour as a brother:

And tho the queenë took hym out aside,

Tolde hym pleynly it was ful unsittyng

Swich doublenesse to fynden in a kyng,

And seide hym ek al-thoh he were strong,

To his brother how he didë wrong. (III.3648-52)

Jocasta continues, warning that many "that ben Innocent" will suffer because of the feud between Eteocles and Polymyte (3669-72). These are people for whom, as the current ruler, Eteocles is ultimately responsible. As a ruler, his refusal to reconcile with his brother and to uphold a promise made has devastating consequences for the people of Thebes. Failure to uphold fraternity is linked consistently throughout the Siege to the inability to be a good and worthy leader.

Eteocles continues to refuse to uphold his vow to give control of Thebes to Polymyte at the end of the year, even after Tydeus has departed from the court. However, due to pressure from both Jocasta and the other lords, Eteocles agrees to consider a treaty 
if Polymyte will agree to rule as a lord of Thebes under Eteocles's authority. Jocasta brings this offer to the Greeks, explaining that Eteocles is willing to offer the following:

The honour hool and the regalye,

With Sceptre and Crounë fro hym not devyded,

Bot hool to hym as he hath provided;

And Polymyte, be this condicioun,

Vnder hym to regnen in the toun

As a Soget, be suffraunce of his brother. (III.3758-63).

The Greeks, and especially Tydeus, refuse to accept this compromise, demanding that Polymyte be given the full reign of Thebes as is his right, both by birth and according to the vow Eteocles made a year prior. This represents another contrast between Eteocles and Tydeus, as Eteocles does all he can to keep power from Polymyte, to the point of being willing to go to war to fuel his own greed and hatred. He not only wishes to maintain what he owns, but also seeks to prevent Polymyte from gaining anything. It is not merely about keeping his rule and land; it is also about denying Polymyte the same. Tydeus, on the other hand, will accept nothing less than what his sworn brother is owed. Tydeus enters war not because of his own anger or desire, but to right a wrong done to his sworn brother, Polymyte. Tydeus acts not out of self-interest, but out of brotherly love. His motivation for war is not greed, but fraternal loyalty.

Unlike Polymyte, Eteocles shows no indication that he is willing to learn how to be a good brother and, thus, a good leader. It is Eteocles's refusal to accept Tydeus' instruction which creates the final stark contrast between himself and Polymyte. Not only does Polymyte display a shift in his characterization, in his new adherence to fraternal 
loyalty through his devotion to Tydeus, he also displays a shift in his understanding of the bond of brotherhood he shares with Eteocles. While Polymyte does go to war against Eteocles, at the urging of Tydeus and the other Greeks when he is denied the crown, he displays a new awareness of the loyalty which he owes to his consanguine brother. When Polymyte and Eteocles meet on the battlefield, Polymyte admittedly strikes his brother, cutting through his armor, mail, and shield, but he immediately regrets this action:

Polymytës thorgh platys, mayle and sheeld

Roof hym thorgh-out and smette hym in-to feld.

But whan he sauh the stremys of his blood

Raylle about in maner of a flood

Al sodeynly of compassioun,

From his coursere he alighte doun,

And brotherly, with a pitous face,

To saue his lyf gan hym to vnbrace. (III. 4277-84)

Polymyte has come to understand and value the importance of fraternity, though not in time to prevent himself from committing fratricide. Notably, Lydgate uses the term "brotherly" to emphasize Polymyte's compassionate actions, contrasting a moment of compassion and honour with fratricide. The phrase "stremys of his blood" is also significant, as while it is Eteocles's blood that has been spilled, it is also symbolically Polymyte's own blood, which highlights the loyalty he should show to his consanguine brother, with whom he shares this blood. Polymyte, who has already proven himself worthy of a sworn brotherhood with the noble Tydeus and has been rewarded with land and power because of this, attempts to redeem himself for his part in the feud of 
"unkynde blood." Polymyte's actions demonstrate not only his understanding of the blood bond he shares with Eteocles, but also of the damage that their feud has caused. Polymyte does not injure Eteocles here because of a lack of self-governance, as he has been acting according to the code of war. However, he has gained enough self-awareness to understand that hatred and anger bring about destruction. In his final act of attempting to save Eteocles's life, Polymyte demonstrates his own self-governance of his emotions and behaviour.

Unfortunately, Eteocles, just as he refuses to accept Tydeus's example or instruction, refuses to recognize the abhorrent nature of fratricide, and uses Polymyte's act of compassion against him. Eteocles stabs Polymyte in the heart as the other attempts to save his life: "Of al this sorowe verraye sours and welle, / with a dagger in al his peynys smerte, / his brother smoot vnwarly to the herte" (III. 4290-2). Eteocles remains against nature unto his death and, as a result, the brothers are slain by each other at the gates of the city. Polymyte, who has learned the value of brotherhood through his chosen bond with Tydeus, displays his nobility in his attempts to save the life of his consanguine brother, and presents the readers with this redeeming character moment before his own death. Lydgate's text emphasizes that fraternal loyalty is ennobling, both by allowing Polymyte to overcome his unnatural hatred of his own kin and by showing Eteocles to be an unredeemed and unsympathetic character. Because of Tydeus's influence, Polymyte is redeemed by his attempt to overcome fraternal conflict, while Eteocles is condemned for his refusal to do the same.

Careful examination of the connection between fraternity and governance in The Siege of Thebes shows that a deeper and more complex notion of brotherhood emerges 
within Lydgate's text than scholarship has previously acknowledged. This connection between brothers and governance is demonstrated through the key characters of Tydeus, Eteocles, and Polymyte, and their worthiness to rule. Tydeus represents exactly what Polymyte and Eteocles can achieve when brothers are in control of their own emotions and uphold fraternity while maintaining proper kingly behaviours.

Despite the accidental death of his brother, Tydeus's ability to self-govern his own emotions and behaviour remains a positive and necessary example for Polymyte and others. Lydgate's poem further suggests that a blood brother may not be able to fulfill the role of teacher because of the inherent rivalry which exists in consanguine brotherhood, an idea present both within the biblical and classical origins, as seen with Cain and Abel. Cain is neither willing to listen to Abel's advice nor to follow the latter's example of fraternal unity. Polymyte could not learn how to be a good brother to Etecoles, as the inherent rivalry of their relationship created an animosity between them. In Lydgate's view, a Tydeus figure is essential as a chosen or associational brother who stands as a role model of behaviour. Tydeus can reach Polymyte precisely because he is able to overcome the latter's jealousy, demonstrating that a brotherly bond can be one of mutual benefit. They gain land and power together, not in opposition to one another. Tydeus's ability to overcome the accidental fratricide of his own brother, and to continue to demonstrate his self-control through his behaviour as a brother and a ruler, demonstrates the possibility of overcoming the inherently fraught nature of brotherhood. While he fails to rehabilitate Eteocles, his efforts with both Eteocles and Polymyte remain an exemplar of exactly what makes a good brother and a good leader. 


\section{Conclusions}

The Siege of Thebes is explicitly stated to be a "mirror for princes," as well as a text through which contemporary audiences can learn to model their own behaviour. Lydgate asks that audiences take heed of the destruction wrought by the feuding brothers: "Therefor no man be herof reckkëlees / But make zoure myrour of Ethiocles / And his brother callëd Polymyte" (I. 1039-41). Lydgate directly calls upon his readers to apply the lessons taught within the Siege. The fact that most of the manuscripts were "texts prepared for aristocratic or upper-class patrons," as Derek Pearsall points out, suggests that those whom Lydgate hoped to warn against particular behaviour were those who were almost certainly in positions of power and governance. ${ }^{41}$ Pearsall argues that Lydgate's "whole theory of poetry is based on the idea that poets should teach by offering examples of behaviour," quoting The Fall of Princes in which Lydgate writes: "Their cheeff labour is vicis to repreve / With a maner covert symylitude." 42 The connection between the Siege and Lydgate's contemporary world is also highlighted by Lois A. Ebin who argues that "[i]n his poetry, Lydgate responds to contemporary events with a vision of the poet as a civilizer and orderer of man" and stresses that "[i]n Lydgate's own career, the Troy Book and the Siege of Thebes have an important position as public poems in which Lydgate first explicitly directs his skills as poet-craftsman to the concerns of the state." ${ }^{43}$ However, what Ebin does not highlight is that Lydgate does not necessarily view this responsibility as that of a poet alone, but specifically represents himself as both a poet and a monk in the Siege of Thebes. While Lydgate's works address

\footnotetext{
41 Pearsall, Lydgate, 151.

42 Ibid., 12; The Fall of Princes III, 3830-1.

${ }^{43}$ Lois A. Ebin, John Lydgate (Boston: Twayne Publishers, 1985), 39.
} 
political and public issues, his presentation and understanding of these issues are necessarily filtered through his perspective as a monastic brother. He makes this filter explicit both in the Prologue section of the Siege of Thebes and by aligning his models of fraternity and its reformation in this text with fundamental Benedictine texts, such as the Rule. Lydgate's presentation of the connection between fraternity and governance is framed within the values and beliefs espoused by monks in the fifteenth century.

Just as Eteocles and Polymyte's feud has larger consequences for their kingdoms, feuding between Benedictine brothers would have disrupted their goal of working together to live a life in service to God. Just as I found no judicial records of fratricide in the last chapter, I could not locate documented evidence of a specific example of feuding at Bury St. Edmunds during Lydgate's time. However, it is not difficult to imagine that living with others in close quarters and interacting daily could lead to disputes. The fact that the Rule of St. Benedict includes guidelines to follow in the event of disputes indicates that these feuds and disagreements were expected even at the foundation of the order. There are, however, records of feuds between Benedictine brothers from other monasteries. For example, Ekkehard IV of St. Gall documents a number of disagreements at the abbey of St. Gall in the eleventh century. One feud involved three brothers who were granted special privileges by the abbot, such as the ability to meet together for private study in the scriptorium. These privileges invoked the ire of at least one other monk, Sindolf, who attempted to eavesdrop on one such session and ended up being whipped by the three monks. ${ }^{44}$ This conflict demonstrates the potential for fraternal strife

\footnotetext{
${ }^{44}$ See Ekkehard IV, St Gallener Klostergeschicten, Casus Sancti Galli, c.35, ed. and trans. H. F. Haefele (Darmstadt: Wissenschaftliche Buchgesellschaft; 1980). See also Gerd Althoff, "Communication at the
} 
and feuding even among monastic brothers. Fraternal loyalty is something they nonetheless accepted upon entering the order and forgetting those duties of fraternity would have been disruptive to the monastic community.

While I argue for the connection between the monastic fraternity and the Siege of Thebes, this does not preclude the fact that the text would have resonated with the political atmosphere beyond Bury St. Edmunds. The likelihood of fraternal political conflict arising in response to brothers sharing the rule of a city or kingdom would have mirrored real world possibilities in the fifteenth century, as the composition and circulation dates of the Siege place it squarely within a century in which brothers sharing and disputing the rule of the kingdom was a lived concern. As noted in the introduction to this chapter, the Siege was reproduced in numerous manuscripts. The manuscripts range in production from at least 1425 to the end of the fifteenth century. ${ }^{45}$ While many scholars have suggested that the Siege was written between 1420-1422, tying it to the reign of Henry V and the Treaty of Troyes, James Simpson, argues that "its themes of fraternal strife and civic destruction answer more convincingly to events that followed Henry's death. Henry's brothers Humphrey, Duke of Gloucester, and John, Duke of Bedford, both threatened to fill the vacuum created by Henry's death on 31 August 1422."46 Lydgate's retelling of the fraternal conflict between Eteocles and Polymyte, therefore, would have had real political resonance after the death of Henry V. Whatever the composition date may be, the manuscripts of the Siege show it was read and copied

\footnotetext{
Abbey of St. Gall," in Understanding Monastic Practices of Oral Communication (Western Europe, TenthThirteenth Centures), ed. Steven Vanderputten, 11-22 (Turnhout: Brepols, 2011).

${ }^{45}$ Alain Renoir and C. David Benson, A Manual of the Writings in Middle English, 1050-1500. v. 6, ed. Albert E. Hartung (New Haven: The Connecticut Academy of Arts and Sciences, 1980), 2155. 46 Simpson, "Dysemol daies," 15-16.
} 
during the years following 1422, and the number of manuscripts is a testament to the popularity of the poem in the fifteenth century. Additionally, whether the poem was composed before or after the death of Henry V, English copiers and readers alike living after this event would have been able to draw a parallel between the real brothers in charge of their kingdom, and the literary brothers who were unable to rule together. ${ }^{47}$ Because Lydgate's Siege emphasizes the devastating political consequences of a personal feud between brothers, it underscores for Lydgate's fifteenth-century audience the dangers of such a conflict for England specifically, at a time when the nation was under the political governance of two brothers.

Ultimately, the Siege of Thebes explores the fraught relationship of consanguine brothers and so challenges the notion of it being an inherently ideal bond. It contrasts consanguine fraternity with chosen brotherhood, a comparison which will also be explored in the following chapter in the context of the Prose Merlin. In the Siege, Eteocles represents a figure who refuses to let go of his anger and jealousy for the benefit of his brother and his kingdom. It is because of, rather than despite, the overall failure of the education of Eteocles, that Lydgate stresses the necessity of the lessons Tydeus brings to Polymyte and Eteocles. The failure of Tydeus to instruct Eteocles in self-governance, in fraternal obligations, and in good kingly behaviour, does not demonstrate the futility of

\footnotetext{
${ }^{47}$ The connection between the past in Lydgate's work with his contemporary world has also been suggested by Maura Nolan. See Maura Nolan, John Lydgate and the Making of Public Culture (Cambridge: Cambridge University Press, 2005). While discussing Lydgate's Serpent of Division and not the Siege, Nolan argues that Lydgate inserts "the Roman past into Christian lapsarian history" and that his work suggests "that the dangers of the past are contiguous with the present." Nolan, 51. We see this as well in the Siege, as the poem emphasizes the chivalric notion of blood loyalty as a sign of a worthy knight. Nolan also emphasizes Lydgate's "interest in the classical past as both exemplar and other to the present." Nolan, 188. The Siege is certainly one example of this, as Lydgate emphasizes what can be learned from the figures of the past.
} 
the educational efforts, but rather the consequences when such efforts fail. Despite the rivalry inherent in their bond, a man in a position of governance who cannot learn to love his brother risks more than his own emotional well-being; he also risks the lives of those he is charged to govern. The Siege imagines the potential for extreme consequences when powerful rulers engage in fraternal feuding, as successful leadership is intricately connected to one's ability to be or, at the very least, to learn to be both a good ruler and a good brother. 


\section{Chapter Three: The Prose Merlin: The Rise of Arthur}

In the first two chapters of this project, I examine the conflicts which arise when brothers, through a lack of self-governance, are unable to overcome the tendency towards competition that is seemingly inherent in fraternal relationships. In both Chapters One and Two, we see characters driven by greed and anger, who view their brother not as their closest ally but as their main rival for the lands, power, and affection they believe they are owed. While Abel and Tydeus are not driven by these emotions, neither of them can provide enough guidance to avoid the devastating consequences of fratricidal jealousy. When the feuding brothers are in positions of power and governance, their inability or unwillingness to self-govern their own emotions, represented in their volatile behaviour towards their brothers, becomes an indicator of their ineptitude to govern at all. In this chapter and the next, I examine brothers who are not necessarily governing lands and people themselves, but who are actively engaged with the efforts of other rulers to gain or maintain power. The obligations and demands of fraternity under which these men operate play important roles in their ability to help, or hinder, political rulers. This connection between fraternity and governance is central to the narrative of King Arthur and his knights of the round table. Over the next two chapters, I examine how two fifteenth-century authors represented fraternity as, on the one hand, necessary for Arthur's rise to power and, on the other, an inescapable factor in his eventual downfall. This chapter, focused on the necessity of brotherhood for Arthur's rise, studies the role of brothers in the Prose Merlin. I also consider another fifteenth-century adaptation of the Merlin story: Henry Lovelich's verse The Romance of Merlin. The Prose Merlin is the 
focus of this chapter because its manuscript contains narrative beyond that which is found in the Lovelich poem, but Lovelich's text nonetheless provides another important example of the fifteenth-century perspectives through which the Arthurian stories were adapted and transformed for an English audience. Chapter Four will turn to another extensive prose work, Sir Thomas Malory's Le Morte Darthur, to examine the social and political dangers which manifest when characters are unable to overcome the duties of fraternity, even when such demands are at odds with what is best for the kingdom at large. In these two chapters, I trace how different authors understood fraternity as both necessary for the Rise of Arthur and as partially at fault for its eventual downfall.

Within the Prose Merlin, brothers are central figures who aid Arthur in his early days as king. Arthur's rise to power is achieved directly through the aid of brothers. A similar focus on the connection of brothers to powers of governance is found in Lovelich's poem, demonstrating the recurrent focus on fraternity found in Arthurian literature. Both texts emphasize repeatedly the fraternal relationships of characters who are necessary to Arthur's success as a king. From Bors and Ban, brother kings from France, to Gawain, Gaheries, Gaheret, and Aggravain, brothers from Orkney, it is often sets of brothers who are pivotal to Arthur's success as he attempts to build and maintain his kingdom and his power. Whereas in previous chapters I have outlined the difficulties brothers face when they are in competition with one another for power, this chapter focuses on the way in which brothers who are not fighting for their own positions of power are presented as possessing chivalric prowess and, as such, are vital allies for rulers, such as Arthur. The strength of these characters is often paralleled with their identification as a brother, particularly in the Prose. In this way, brotherhood is depicted 
as a source of strength and a force for good, as opposed to its depiction in the tales of Cain and Abel or Etecoles and Polymyte. This is partly evident in the usage of fraternal terms. As I have done in previous chapters, I trace the way in which such terminology is employed throughout the Prose Merlin and Lovelich's text when describing these characters and their deeds. These men are powerful and successful in part because they are good brothers. They draw strength from the bond of fraternity, working together with their brothers for the greater good of the kingdom. Their own self-governance, demonstrated through the fulfillment of ideal fraternal connection, makes them not only helpful but also necessary allies for Arthur during his early years as he attempts to establish himself as king.

\section{Composition of the Texts}

The Prose Merlin was composed around the middle of the fifteenth century by an anonymous author and is found in one extant manuscript: Cambridge University Library, MS Ff.3.11. ${ }^{1}$ The beginning of the Prose is based on Robert de Boron's twelfth-century Merlin, while most of the later Prose is a translation of the thirteenth-century sequels to the French Old French Vulgate Cycle. Scholarship on the Prose continues to remain limited, with few readers, even amongst specialists in the Arthurian field. This lack of interest is likely due, in part, to the fact that, as Michelle R. Warren claims, "[t]he translated text has long occupied a relatively low status within academic culture, due to its seemingly derivative and secondary nature." ${ }^{2}$ Warren argues that "translation offers an

\footnotetext{
${ }^{1}$ The manuscript is missing the last few leaves, but most of the text is preserved.

2 Michelle R. Warren, "Translation," in Middle English, ed. Paul Strohm (Oxford: Oxford University Press, 2007): 5. See also: Ivana Djordjević, “Mapping Medieval Translation,” in Medieval Insular Romance:
} 
opportunity to redefine audiences, social relations, historical inheritance, and ethnic identities" and "translation is not, by definition, a secondary form of writing." 3 The Prose author may be translating from thirteenth-century French sources, but that translation is itself an act of authoring the text for his contemporary audience. The choices and decisions made by the author, to alter or maintain words, aspects, and events of the source text, are all acts of authoring, and the Prose has unfairly been dismissed in the past as "simply" a translation. ${ }^{4}$ I argue, instead, that in the version of the tale he recreated for a fifteenth-century English audience the author of the text made deliberate choices which are important for analysis of the discourse of fraternity within the Prose Merlin.

While dismissals of the Prose as mere translation may not be the only reason this text has been understudied, the lack of attention has meant that numerous elements of the Prose which can contribute to our understanding of late-medieval renditions of Arthurian tales have been overlooked. ${ }^{5}$ While the Prose and Malory share many similarities, in that they are both mid-fifteenth-century prose adaptations of the Arthurian story, the latter has received far more scholarly attention. In fact, most scholarship has tended to explore the Prose text primarily through its similarity to the source texts. This focus on source study has suggested that the text cannot be read as a unique or creative endeavour, with few

Translation and Innovation, ed. Judith Weiss, Jennifer Fellows, and Morgan Dickson, 7-24 (Cambridge: D. S. Brewer, 2000). In this article, Djordjević explores the poetics of medieval translation, using Sir Bevis of Hampton as a case study.

${ }^{3}$ Warren, 51-52. See also: Rita Copeland, Rhetoric, Hermeneutics, and Translation in the Middle Ages: Academic Traditions and Vernacular Texts (Cambridge: Cambridge University Press, 1991).

${ }^{4}$ For a further study on the nature of medieval authorship as translator see Matthew Fisher, Scribal Authorship and the Writing of History in Medieval England (Columbus: Ohio State University Press, 2012). ${ }^{5}$ In her PhD dissertation, Ambra Finotello outlines some of the reasons why the Prose has received little attention. Finotello, Ambra. "Transformations of the Merlin Legend in Late-Medieval England: Contextualizing Translation in 'of Arthour and of Merlin', Henry Lovelich's 'Merlin', and the 'Prose Merlin'," PhD diss. Bangor University, 2014, 156-9. 
studies fully acknowledging the deliberate choices the author of the Prose would have made in the creation of his own, new version of the Merlin story. ${ }^{6}$ The dominance of source study has meant that the effect of the translation on the reading experience of the audience has been overshadowed by considerations of accuracy or deviation. The Prose author made deliberate choices which create the fifteenth-century text as related to, but ultimately separate from the French poem and Vulgate version of the Merlin tale. These choices range from decisions to produce a word-for-word translation of phrases, to decisions to omit or expand passages entirely. Each choice made by the author, whether to emulate or change his source material, all lead to the creation of a new text, one composed specifically for a fifteenth-century English audience in a period in which fraternity was prominent in social and political formations of power.

One of the elements which has been overshadowed by studying the Prose as merely a translation of the two thirteenth-century French texts has been the role which brothers play within the tale, particularly in relation to the foundation of Arthur's reign. While the Prose follows the history of Merlin, as John Conlee suggests, it "also presents a detailed account of the initial phase in the evolution of Arthurian civilization, a phase which may be called the Rise of Arthur."7 This evolution, I argue, is made possible specifically through the actions of key brother-groups within the text. The Arthurian

\footnotetext{
${ }^{6}$ Such criticism was not confined to the Prose Merlin, as several critics have viewed the fifteenth century as lacking in literary achievement, particularly when compared to the fourteenth century. See, for example, W.R.J. Barron, Middle English Romance (London: Longman Press, 1987). For examples of an argument against such claims, see David Lawton, "Dullness and the Fifteenth Century," ELH 54 (1987): 761-99; Helen Cooper, 'Introduction', in The Long Fifteenth Century: Essays for Douglas Gray, ed. by Helen Cooper, S. Mapstone and J. Fichte, 1-14 (Oxford: Clarendon Press, 1997); and Helen Cooney, Introduction in Nation, Court and Culture: New Essays on Fifteenth-Century English Poetry (Dublin: Four Courts Press, 2011): 11.

7 John Conlee, Introduction to Prose Merlin, ed. John Conlee (Western Michigan University: Medieval Institute Publications, TEAMS, 1998), 2.
} 
world presented within this text is one which, in many ways, relies upon fraternal groupings both in its establishment and in its maintenance. The Prose author reaffirms fraternity as a necessary element of a cohesive and successful kingdom under Arthur and glorifies brotherhood as an ideal homo-social bond. ${ }^{8}$ Terms of fraternity are used within the Prose Merlin over two hundred and seventy-five times. The terms "brother" or "brethren" are used predominantly as narrative descriptors of characters. The text categorizes numerous characters as "brother of," to establish for readers exactly who is being discussed, and to remind them of the position of the characters within a fraternity. Two hundred of these terms refer to either Uther and Pendragon, Ban and Bors, or the sons of Lot. These three groups of brothers account for eighty percent of fraternal terminology used within this text. Brothers in this text are responsible for the creation and maintenance of Arthur's kingdom, and the importance of this fraternal relationship is evident in the fact that the text continually emphasizes the characters' status as brothers when highlighting their service to Arthur. Uther and Pendragon signal the early valorization of brotherhood as the foundation of the kingdom — an element of the tale crucially not found in Malory's text, as will be examined in the next chapter. Throughout the Prose, the different sets of brothers are constantly identified through their fraternal bonds. After the death of Pendragon, Uther becomes Uther Pendragon, taking on his brother's name as part of his own identity as king, signifying the close bond of the two men (57). Ban and Bors become "the two brethern that were kynges," while the sons of

\footnotetext{
8 This is in opposition to Malory's text, which emphasizes the dangers of excessive fraternity to the cohesion of the Round Table fellowship and the realm, as will be explored in the following chapter.
} 
Lot are commonly identified through their relationship to one another. ${ }^{9}$ These three sets of brothers, to whom the terms associated with brotherhood most often refer, all play key roles in the establishment of Arthur's kingdom. From his father, Uther, who fights alongside his brother Pendragon to gain their rightful land back from Vortigern, to his nephews, Gawain and his brothers, who protect Arthur's city while he is on campaign, it is brotherly groups which make it possibly for Arthur to take and hold the crown at all.

Like the Prose, Henry Lovelich's Merlin has also been understudied, having likewise been dismissed because of its status as a translation. Warren argues that Henry Lovelich was "one of the least-loved writers of Middle English literature" and "[b]ecause of his amateur relation to literature, Lovelich's project challenges some generally held assumptions about linguistic competence and the social roles of books in fifteenthcentury London." ${ }^{10}$ Lovelich has been called a "hack" and his work is generally not read except by specialists in the field. ${ }^{11}$ His text survives as an incomplete verse translation of Robert de Boron's text and consists of 27,852 lines. ${ }^{12}$ Like the Prose author, Lovelich worked as a translator while also working as an author. Additionally, like the Prose manuscript, Lovelich's book was also meant for use as the manuscript, Cambridge, Corpus Christi, MS 80, "is designed for illustrations that were never completed." 13 Lovelich's text was one which was intended to be used and read. Much scholarship on

\footnotetext{
${ }^{9}$ Gawain and his brothers are also commonly referred to as the "sons" of Lot, often while they are identified as brothers. The ties between fathers and sons and between brothers are, thus, two of the most important relationships in the Prose.

${ }^{10}$ Warren, 53.

${ }^{11}$ For an examination of some of the dismissals of Lovelich's work, see Roger Dalrymple, "'Evele knowen 3e Merlyn, jn certeyn': Henry Lovelich's Merlin" in Medieval Insular Romance: Translation and Innovation, eds. Judith Weiss, Jennifer Fellows, and Morgan Dickson, 155-67 (Cambridge: D. S. Brewer, 2000). ${ }^{12}$ All quotations and references to Lovelich's text are taken from the following: Henry Lovelich, Merlin, 3 vols. EETS o.s. 185, e.s. 93, 112, ed. Ernst A. Kock (London: K. Paul, Trench, Trübner \& Co., 1904-1932). ${ }^{13}$ Warren, "Translation," 57.
} 
Lovelich focuses on the identifiable author, and his profession as a skinner, often as a means of explaining his lack of training in the art of translation and writing. ${ }^{14}$ However, just like the Prose author, Lovelich, as a translator and as an author, made specific choices about what to maintain or change in his own text from his source. Many of those choices reflect an attitude towards fraternity similar to that found in the Prose.

The similarities between both texts have been noted by William Edward Mead, who argues that the Prose Merlin and Lovelich's version exhibit "a remarkably close general agreement" between them. ${ }^{15}$ While Mead focuses on what these similarities mean in terms of an original French source, I argue that in attempting to locate or argue for a singular, similar, or even lost source, comparisons of the two texts have neglected to consider the significance of the deliberate choices by both authors to preserve fraternity as a pivotal homo-social bond in the foundation of the Arthurian community. Even if the resemblances between the two texts can be explained by a common French source, the fact remains that both translators, working independently of one another, opted to maintain the significant role of fraternity within their translations and to characterize it as constructive ${ }^{16}$ In doing so, both authors reaffirm for their fifteenth-century audiences the pivotal role of consanguine fraternity in political events of the period through the representation of brother groups as central to Arthur's war efforts and integral to the

\footnotetext{
${ }^{14}$ For an exploration of the need for further scholarship on Lovelich's Merlin see Robert W. Ackerman, “Herry Lovelich's Merlin," PMLA 67, no. 4 (June 1952): 473-84. For an example of work on Lovelich, see Michelle R. Warren. "Lydgate, Lovelich, and London Letters," in Lydgate Matters: Poetry and Material Culture in the Fifteenth Century, eds. Lisa H. Cooper and Andrea Denny-Brown (New York: Palgrave Macmillan, 2008): 113-38.

15 Introduction in Merlin, or the Early History of Arthur: A Prose Romance, EETS o.s. 112, ed. Henry B. Wheatley (London: K. Paul, Trench, Trübner \& Co. 1899), LXIII.

${ }^{16}$ Daniel Wakelin also emphasizes the need to emphasize the effort and artistic vision invested in scribal decisions to maintain sameness. See: Scribal Correction and Literary Craft: English Manuscripts 13751510 (Cambridge: Cambridge University Press, 2014).
} 
establishment of the Arthurian powerbase. This potential for fraternity to be a positive force for good builds upon the potential which is hinted at in Lydgate's Siege of Thebes. While the Siege ultimately demonstrates the devastation caused by brothers who are unable to overcome the inherent rivalry of fraternity, the possibility of consanguine fraternity working well for the benefit of the brothers as well as the realm is nonetheless present. Both the Prose Merlin and Lovelich's text engage with this possibility, imagining exactly how positive consanguine fraternity can be as a source of power and influence, rather than of conflict and destruction.

While terms of fraternity in Lovelich's Merlin occur less frequently than in the Prose, it is difficult to ascertain the true extent of this difference as it exists at least in part because the manuscript of Lovelich's poem ends earlier in the narrative than the Prose. What is significant, however, is that just like the Prose Merlin, Lovelich's references to Uther and Pendragon, Bors and Ban, and the sons of Lot account for a large percentage of the use of fraternal terms. In this tale, Uther also takes on the surname Pendragon (420712). Uther and Pendragon in Lovelich's text are associated with terms related to brotherhood almost fifty separate times. For example, when speaking of Uther or Pendragon, very often Lovelich includes a term of fraternity to identify them specifically through this relationship. Examples of this include the following lines: "bothe his bretheren" (2974), "the tweyne bretheren that now fled j-be" (3000), "and also vter, his brothir so dere" (3077) "the tweyne bretheren gonnen hem asaylle" (3113) "of vter, my brothir," (3458) and "that vter his brothyr" (3481). These characters come to be associated first and foremost through their roles as brothers, as that is how they are identified by both the author and the characters within the texts. Ban and Bors are 
referred to as the "brethren that kynges were" (9084) and, so, are also identified through their bond to one another. The Orkney brothers, too, are commonly identified through this bond. Often, Gawain is named while the others are associated with him as his brethren. Lovelich, like the Prose author, has chosen to maintain an emphasis on the fraternal relationships of these characters specifically, even when facing the task of translating the text into English verse. These characters are known as brothers. They are repeatedly and consistently presented to the readers as brothers. And just like the Prose, terms of fraternity become key narrative descriptors for these characters. Lovelich's readers are continually reminded of the presence of fraternity. Both Lovelich's Merlin and the Prose present a vision of the Arthurian world in which brotherhood is valued as one of the most important social bonds between men. Fraternity, along with characters who are consistently identified through such bonds, becomes an example of unwavering loyalty and, as such, of idealized community. Fraternity becomes a necessary force in establishing power, and brothers are key players in political and military events.

\section{Necessary Fraternity and Claiming a Kingdom}

While the brothers Ban and Bors and the Orkney brothers are crucial allies for Arthur at the beginning of his reign, Uther and Pendragon make up the first set of brothers to be highlighted as key characters within these texts. Examples of the repeated identification of Uther and Pendragon as brothers demonstrate the ways in which the author of the Prose Merlin, as well as Lovelich, have underscored their fraternity as one of their dominant characteristics. In the Prose Merlin, this connection between their roles as brothers and their individual characters is evident, for example, in how often Uther and 
Pendragon are referred to as brothers: "till that the vessel that the two brethern were inne come into the havene" (42); "and the two brethern assailled hym" (42); "I shall leve the reame to my brother Vter" and "for thy brother Vter hath hym slayn" (44); "to Vter his brother" (54). Perhaps the most substantial evidence for the dominance of fraternity in the characterization of these men occurs in a singular speech made by Merlin to Pendragon:

"A-noon as ye were departed fro youre oste, to com hider, Aungiers wolde haue morderid thi brother in his teinte. And I wente to thi brother, and warned hym of Aungiers purpos, and of his strengthe, and how we wolde come be nyght hym-self to his teynte, formeste of his company. And thi brother dide not mystruste me, but made good waicche all that nyght, sole be hym-self, till that Aungiers come with a knyf in his honde, to sle thi brother.... And at the comynge owte thy broper faught with hym and slowe hym his owne handes." (46; emphasis mine $)^{17}$

In this speech alone, Merlin uses the term "brother" five times when speaking to Pendragon. The reader of such a passage cannot ignore the fact that, in this moment, Uther's role in the text is as a brother. He is identified, repeatedly, through his fraternal bond with Pendragon. Lovelich's version of the same speech also utilizes the term brother five times:

"Sire," quod Merlyne, "as it not ben scholde, Augwys vter mordred han wolde. Anon to thy brothyr $\mathrm{j}$ wente jn hye,

\footnotetext{
${ }^{17}$ All quotations from the Prose Merlin are taken from the following edition: Merlin, or the Early History of Arthur: A Prose Romance, ed. Henry B. Wheatley, EETS o.s. 10, 21, 36, 112 (London: K. Paul, Trench, Trübner \& Co., 1865-99).
} 
and told hym al his purpos vtterlye,

and how that augwys hym ordeynede to sle;

so that zowre brothir wook alone al nyht,

tyl that the sothe he preven myht,

and evere awayed the comenge

of Augwis, pat was so crewel a kynge.

thanne atte laste cam this haugwis

jnto vteris pavyloun, pat was of prys.

and zoure brothir let hym entren anon,

but zoure brothir mette with hym anon.

So there fowhten they to-gederis, jn certayn,

That vter, zoure brothyr, hath hym slayn.” (3417-40; emphasis mine)

Readers are constantly reminded through repeated use of the term "brother" that these two characters are bonded thought fraternity. Both Lovelich and the Prose author include the term "brother" multiple times in Merlin's speech, even though doing so creates redundancy, particularly when it is used in conjunction with Uther's name. "Your brother," while often used as a replacement for Uther's name, is also used with the name. The dual naming further connects the individual to his fraternal role. Readers are reminded constantly of the fraternal connection between Uther and Pendragon while learning of their efforts to regain the land that should have rightfully been theirs. 
The effect of the repeated terminology is further heightened when one examines the manuscript page from the Prose on which this speech appears. Folio 15b, which begins with this speech, contains eleven fraternal terms. The reader of the manuscript cannot escape this social bond of kinship. Whether hearing or reading the text, the audience would inevitably encounter this repetition, and the condition of the manuscript suggests that this text was one which was, indeed, read, held, and used. The manuscript shows the sign of wear and tear from use, rather than simply from age. Carol M. Meale argues that "despite the frustration which this destruction entails for the modern reader, the most important point, which it does not obscure, is that the Cambridge manuscript is no pristine library copy: the Merlin was read - indeed scrutinised - with great attention." ${ }^{18}$ It should also be noted that as prose, the repeated references to "brother" are not necessary or required for maintaining the meter of a line or the rhyme pattern. Any number of these terms could be removed without consequence. The reader is aware of the brother-bond between these characters, but the narrator continuously reinforces the relationship. ${ }^{19}$ We are continually reminded of the thematic linking of fraternity and foundational governance. Brothers are at the heart of key moments in which political

\footnotetext{
${ }^{18}$ See Carol M. Meale, "Manuscripts and the Early Audience of the Middle English Prose Merlin," in The Changing Face of Arthurian Romance: Essays on Arthurian Prose Romances in memory of Cedric $B$. Pickford, eds by Alison Adams, Armel H. Diverres, Karen Stern, and Kenneth Varty, 92-111 (Cambridge: Boydell Press, 1986), 98, Arthurian Studies 16. The audiences of the Prose and Lovelich's text were likely variant from one another. While the Prose appears to have been read and owned by aristocratic audiences, Lovelich's text was produced by a member of the merchant class, a skinner. For further consideration of the audiences of the Merlin texts, see Karen Stern, "The Middle English Prose Merlin," in The Changing Face of Arthurian Romance: Essays on Arthurian Prose Romances in memory of Cedric $B$. Pickford, eds by Alison Adams, Armel H. Diverres, Karen Stern, and Kenneth Varty, 112-22 (Cambridge: Boydell Press, 1986), Arthurian Studies 16.

${ }^{19}$ Terms of fraternity are used by the narrator just under two hundred times in the text, making them the most common familial term used by the narrator. The next closest term, "son," is used almost one hundred and seventy times. The only other term that is used over one hundred times by the narrator is "wife," at one hundred and twenty-five times.
} 
power is gained, regained, and maintained. Arthur's kingdom, and his ability to rule over it, begins with his father, working with his brother, to reclaim the lands. Fraternity is more than connected to the establishment of political power, it is necessary for it. In these versions of the Arthurian story, governance is made possible through the efforts of men bonded in fraternity.

Both Lovelich and the author of the Prose text would have encountered fraternity as an important element of their source materials, as both the Vulgate and Robert de Boron's versions of the tale also emphasize the role of brothers. However, the Prose and Lovelich's translation expand the importance of these elements, using fraternity as an ideal model for chivalric community. The increased predominance of chosen brotherhood in the Prose text has been noted by Ambra Finotello, who explores the creation of a fifteenth-century English ideal of chivalric brotherhood in her doctoral dissertation.

Finotello suggests "that the translator was aiming at promoting an ideal of chivalry and of the Round Table that differs greatly from that found in the Estoire" and that "the Prose Merlin is the first English romance where the Round Table is defined as a 'fellowship' and its knights as 'brothers'. ${ }^{20}$ Finotello's main argument for this observation is based upon the moment of the foundation of the Round Table under Uther in the Prose Merlin.

\footnotetext{
${ }^{20}$ Finotello, 150. Finotello also challenges William Mead's view that there must be a lost source for the Prose Merlin. Finotello points out that "[d]espite his extensive research on the manuscripts of the Estoire surviving in France and England, William Mead was not able to identify the French original and ruled out the possibility that any of the extant copies of the Estoire can be considered the direct source of the Prose Merlin. However, instead of contemplating the possibility that the differences between the Prose Merlin and the Estoire might derive from a conscious process of selection and interpretation by the author, Mead considers the theory of a lost source." Finotello, 157; William Edward Mead, "French Manuscripts of Prose Merlin," in Merlin, or the Early History of Arthur: A Prose Romance, EETS o.s. 112 (London: K. Paul, Trench, Trübner \& Co., 1899), clxxxiv.
} 
In this version of the tale, the men gathered express their fondness for one another and for the strength of the new bond binding them:

And when they departed, the kynge come to the fyfty knyghtes, and axed how hem lyked. And thei seyde, 'Sir, we haue no talent to remeve fro hens, and ther-of we haue merveile what it maketh, for we be entred as brethern; and therfore we will neuer departe till deth vs departe.' When the kynge herde hem thus sey, he hadde grete merveile, and comaunded hem to be serued and kepte as his owne body. And thus departed the grete prese. (Prose, 61)

As Finotello argues, one of the most significant terms in this passage is the word "brethern," which represents a narrative change from the French Estoire. In the Vulgate, the men who are gathered also express their surprise at their desire to remain together: "si nous meruellons moult comment ce puet ester. Car il en i a de tels de nous qui napartenons lun lautre $\&$ ne nous estiens onques entre ueu et poi en $\mathrm{i}$ a de nous dont li vns fust acointes del autre .\& ore nous entramous tant ou plus comme fiex doit amer son pere . ne iamais ce nos est auis ne nous departirons se mors ne nous depart." $(55.32-37)^{21}$

("Yes indeed! And yet we wonder at how this can be. For many of us have no bonds with any among us; others have not seen one other before, and few of us were friends before. And now we all love one another as much

\footnotetext{
${ }^{21}$ Estoire de Merlin, The Vulgate Version of the Arthurian Romances, ed. by H. Oskar Sommer, vol. 2
} (Washington: The Carnegie Institution of Washington, 1908-13). 
as a son should love his father, or more, and it does not seem to us that we will ever be parted unless it is by death."22)

In the French Estoire, the men view their newfound love for one another as akin to the love of a father for a son. Finotello argues that "the most striking alteration introduced by the Prose Merlin translator concerns the knights' tentative description of the nature of the affection that unites them." 23 The knights in the Prose Merlin understand their newly established love for one another as that which one would feel for a brother, rather than that of a son for a father. The Prose text creates a bond between men that is based on equality rather than authority. They love each other as brothers, as equals, not because of a sense of paternal authority either has over the other but while Finotello describes the knights' emotional reaction as "the tentative description ... of affection" I argue it is more accurately categorized as amazement. These men, who, as they state, have not all known each other beforehand, feel a fraternal bond has formed between them and they are in wonder that such a strong bond could be formed in such a short period of time. It suggests that fraternity, and the love of brothers for one another in this world, is a powerful force, indeed.

The shift from the love of a father to the love of brethren as a uniting force for the fellowship of the Round Table is also present within Lovelich's version of the scene. When Uther asks the men how they feel about their new company, they answer:

"Jt Js owre wylle Neuere hens to gone

\footnotetext{
22 Translations of the Vulgate are taken from: Rupert T. Pickens, trans, Lancelot-Grail: The Old French Arthurian Vulgate and Post-Vulgate in Translation, vol. 2, The Story of Merlin, ed. Norris J. Lacy (Cambridge: D. S. Brewer, 2010), 62.

${ }^{23}$ Finotello, 183.
} 
Neper neuere to parten oure compeny onsondyr,

For so as we loven to-gederis, it is gret wondir,

For as brethren we loven to-gederis jn fere,

and, tyl deth vs sondre, neuere to departen ere." (4440-4)

In both the Prose Merlin and Lovelich's text, paternity as an ideal bond is replaced by fraternity. It is a fraternal bond that is upheld as the most ideal, and the emulation of which unites the Round Table Knights together for the first time. ${ }^{24}$

As Finotello rightly notes, the shift from father to brother is significant, as it suggests that the ideal chivalric bond is conceived of differently by the Prose author and the author of the Vulgate. Her study explores fraternity as a model for chivalric associations, an idea which is strengthened when one considers the importance and prominence of consanguine brotherhood found throughout the rest of the text. While the men of the Round Table have formed a tie to one another modeled on fraternity, their bond is one of affective or chosen brotherhood. I argue that it is consanguine brothers, and not the affective brotherhood formed at the founding of the Round Table, who play the most significant role in Arthur's efforts to become king and maintain his power in the face of civil war and Saxon invasion. In the case of Ban and Bors, as will be discussed shortly, their bond is neither consanguine nor chosen, as they are bonded through marriage as brothers-in-law. I argue, however, that their relationship is represented in the text as closer to the of consanguine brothers, particularly through the repetition of fraternal terms associated with them.

\footnotetext{
${ }^{24}$ This positive force of fraternity for a kingdom is at odds with the destructive nature of fraternity which will be seen in the next chapter in Malory's Le Morte Darthur.
} 
In the Prose, chosen brotherhood is established in the reign of Arthur as an ideal form of unity between the knights who protect the kingdom, but it is consanguine brothers who are present to aid Arthur in key moments of political unrest and uprising. Finotello, as well as many others, have focused their attention on the fellowship of the Round Table and the importance of affective brotherhood in Arthurian literature. In this chapter, and the next, I focus on the importance of Arthurian consanguine fraternity which, while not ignored completely, is often overshadowed by considerations of sworn brotherhood. While the brotherhood of knights is significant, I argue that it is consanguine fraternity that offers the most essential and constructive aid to Arthur in the polity-building within these Merlin texts. This confidence in consanguine fraternity as a source for good is not inherent in Arthurian literature, as will be explored in the next chapter. But I argue that both Lovelich and the Prose Merlin authors represented the competitive nature of fraternity as something which can be overcome, and that brotherhood can be a powerful social relationship which works for the good and the unity of the kingdom. Unlike Cain and Abel, Eteocles and Polymyte, and, as will be examined in Chapter Five, Johan and Gamelyn, the characters in the Prose Merlin and Lovelich's verse represent the potential for brotherhood to be a positive force in society.

The prominence of fraternity as central to the political events in which Arthur is active is demonstrated best through the depictions and actions of Bors and Ban and the Orkney brothers. Both sets of brothers help Arthur establish his realm and maintain control of it in the face of both civil war and the threat of Saxon invasion. The importance of both sets of brothers as necessary for the creation and maintenance of Arthur's realm is established before the characters become active figures in the narrative. Merlin counsels 
Arthur to seek the help of Bors and Ban before they appear in the text, identifying them by their relationship as brothers. Merlin introduces them to Arthur, and readers, as characters who are brothers first and foremost and who will help Arthur in his quest to gain control over the country:

"And on that other side, in litill Breteyne, ben two kynges, which ought to be thy men; and they haue wedded two sustres to their wyfes, and owen to holden their londes of the; and thei be men of high lynage, and be bretheren germain. These two bretheren shull haue sones whiche shull be merveilouse gode knyghtes, that in no londe shall be founde noon better. That oon of these two kynges is cleped the kynge Ban of Benoyk, and the tother is cleped the kynge Bors of Gannes... for thyn enmyes wolde deffende the fro the londe; but ther-to shall thei not endure ne haue power for the helpe of these two kynges that shull be in thy company." (Prose, 122-3)

Merlin immediately establishes the figures as brothers when introducing them to Arthur, this time through the bond of marriage. Bors and Ban are identified as "bretheren germain," having become brothers through marriage. The Middle English "germain" has two definitions. The first is "of the same parents or stock, near of kin," and the second is a figurative use meaning "having a close spiritual affinity," often associated with fellow Christians. ${ }^{25}$ In the case of Bors and Ban, these two men are not biological kin, but despite being brothers through marriage, the text treats the bond between them in the same way it does that of consanguine brothers, such as Uther and Pendragon. The Prose,

\footnotetext{
${ }^{25}$ Middle English Dictionary, s. v. germain.
} 
as previously seen through the bond formed among the Round Table knights, views all forms of brotherhood as valid and central to the Arthurian world. The necessity of Ban and Bors for Arthur's success is reemphasized later in the narrative when it states: "and all men seiden a-noon as thei it wisten, that neuer hadde thei herde of two so noble men as were the two bretheren, and seide well that yef thei two ne hadde not ben, the kynge Arthur hadde all lostes" (370). Again, Ban and Bors appear as a fraternal duo rather than as characters acting independently from one another in opposing Arthur's enemies. They aid Arthur together, and are identified by both the narrator and characters within the text specifically through their positions as brothers. The Prose establishes the necessity of bonds of this type for the foundation and maintenance of the Arthurian world.

The introduction of Ban and Bors as "bretheren germain" is significantly not present within the Lovelich text, demonstrating one example of how these two authors independently curate the prominence and importance of brotherhood in their translations and adaptations of the earlier French works. In Lovelich's poem, Ban and Bors are introduced to Arthur by Merlin thus:

“also, Sire, jn lytel Bretayngne,

Dwellen tweyn kynges, jn certeyne, the wheche they holden both of the, and cosynes germayn both they be. and tweyne sostres j-weddyd the han perto, that cosynes germayne there ben also. (8655-60)

The choice of "cosynes germayne" rather than "bretheren germaine" to identify the relationship between these two characters is a significant variance from the choice made 
by the Prose author. While cousin in Middle English was utilized to signify numerous male kin relations, which could theoretically include brothers-in-law, as Ban and Bors are, Lovelich, in this instance, is not highlighting the brotherhood of these characters to the same degree we have seen in the Prose. ${ }^{26}$ Even if both authors were working from the same source material, their decisions to maintain or alter even singular terms are examples of the artistry of their work. The Prose author, in deliberately calling Ban and Bors brothers from the first reference to them, heightens the significance of that nature of their relationship. Merlin, in the Prose but not in Lovelich, presents the men who will be of help to Arthur as brothers, first and foremost.

Ban and Bors are not only introduced as brothers in the Prose but are constantly identified through that bond. Ban and Bors are often labelled as brothers, either in addition to their names or in place of them, as seen in some of the following examples: "And the two brethern that were kynges seidge that they were greved gretly with a werre" (130); "he was at parliament with his brother kynge Boors of Benoyk" (125); "And more thei wolde haue don, but for the drede of the two brethern that were kynges" (126); "kynge Boors his brother" (128); "and the two kynges that were brethern"; "be the counseile of kynge ban and the kynge Broos, his brother" (146) "and so died hys brother, the kynge Boors, of gannes" (210). As seen in these examples, not only are Bors and Ban referred to as brother of the other, but they are also often identified simply as "the two brethern" or "the brethern." Terms of fraternity are used in relation to these characters almost seventy different times in the Prose. While they have individual identities and roles in the text, these are inseparable from their positions as brothers. In fact, even when

\footnotetext{
${ }^{26}$ Middle English Dictionary, s. v. cosin.
} 
they have not been active within the text for an extended period of time, they are referred to as "the two kynges that were brethern" (561). The narrator does not even give the characters a name at this point - they are identified solely through their fraternal relationship and, as such, readers who are accustomed to seeing Ban and Bors referred to in such a manner are, thus, able to identify who is being referenced in the text. This fraternal identification is replicated when Arthur makes his final departure from Bors and Ban in the text:

On the morowe the kynge Arthur departed fro the two kynges that were brethern, and after that tyme he saugh hem neuer more; and that was grete scade that they sholde die so soone, as the storie shall declare whan tyme cometh.

Whan the kynge Arthur was departed fro the two kynges that were brethern, that so moche honour hadde hym don. (678) Ban and Bors are "the kynges that were brethern" above all else. It is this repeated phrase which comes to represent these characters, to a point where the reader does not even need their names in order to identify them. Their ability to help Arthur create his own powerbase is explicitly linked to their positions as kings which, in turn, is linked to their roles as brothers.

Just as Ban and Bors are introduced by Merlin as brothers, the Orkney brothers are identified in a similar fashion when first mentioned by Merlin in conversation with Arthur. They are also immediately identified as key figures who will help Arthur gain and maintain control over his lands. Merlin, providing Arthur a lineage of his family, describes Gawain and the other brothers: 
"And wite well that the kynge loth hath v sones by his wif,... and the eldest hight Gawein. And wite thow well that he shall be the trewest knyght of all the worlde a-gein his lorde; also he shall be oon of the beste knyghtes of the worlde, and moste shall the love while his lif doth endure, and shall the helpe agein all the worlde and agein his owne fader; and ne doute not that thourgh hym shalt thow haue a-gein all thy londe... and also be the helpe of his brothern, whiche shull be so noble knyghtes." (122) While Gawain is named as the primary knight who will help Arthur, his brothers are also specifically mentioned as aiding him in his efforts to restore Arthur's lands to him. When the Orkney brothers do become active characters, the text firmly establishes their role as aids for Arthur in the fight against the Saxons and the rebel kings who refuse to yield to Arthur's rule. In their search for Arthur, the Orkney brothers find themselves at Logres, which is surrounded by burnt and wasted lands: "And whan the childeren herde that the kynge was not in the contrey, thei seide thei wolde the londe [sic] and the contrey for her oncle, and also the pray that the saisnes ledden, and that thei wolde kepe the londe and it deffende till here oncle were come home" (Prose, 192). While the Orkney brothers are not singled out as brothers from the rest of their fellows in this instance, their roles in helping are displayed through the formal oath they make to protect the land until Arthur can return. Gawain and his brothers appear on the scene as a fraternal group devoted to the well-being of their uncle's estate and realm. In this way, successful kingship, in the Merlin texts, in part depends on the ability to draw upon pre-existing bonds which already link powerful men throughout the territories. 
Just as Bors and Ban are referred to as brothers throughout the Prose, so, too, are the Orkney brothers. They are referred to through that bond over one hundred times throughout the tale. Notably, they also account for four of the eight times in which a character directly calls another "brother." However, the use of "brother" or "brethren" as a character signifier functions slightly differently in the case of the sons of Lot than that of Bors and Ban, who appear throughout the text as relatively equal in power and standing. In the Orkney case, Gawain often stands out from his brothers, and Gaheries, Gaheriet, and Agravaine are usually identified through their fraternal relationship to Gawain. This is first noticeable in the quotation above, when Gawain is the only brother named while the others are referenced only as "his brethern, which shull be so noble knyghtes." (122) Even when they first appear in the text, they are identified through their relationship to Gawain, as their mother speaks to Gawain, blaming him for the actions, or lack thereof, of both himself and his brothers: "I se yow and youre bretheren that spende youre tyme in foly ... and therfore ar ye moche to blame and youre bretheren" (182). Gawain is also the central figure when Galashin sends for the help of his cousins, as the cousins are identified only as Gawain's brethren, and not by their names, several times: ... he toke a messenger, and sente to Gawein his cosyn, and prayde hym to speke with hym at newerk in privy wise, and to brynge with hym his bretheren, and that he faile not to be ther the thirde day after Pasche. The messenger iourneyed forth till he com in to walis in the marche af Orcanye, and spake with Gawein and his bretheren, 
And whan he [Galashin] com thider, Gawein ne hys bretheren were not yet I-come. And ther he a-bode till thei were come. Whan Gawein and his bretheren were come, Galashin made to hym grete feste. And than seide Gawein to Galashin, "feire cosin, ye sente for to seche me this othir day by youre message that I and my bretheren sholde come speke with yow." (189)

Gawain is the central figure but is still directly connected to his brothers. It is both Gawain and his brothers who are sent for by their cousin. The consanguine fraternity is presented as a package deal. Gawain acts, at least in this moment, as part of a group of brothers and not on his own. ${ }^{27}$ Even in later battles, Gawain is the central figure through whom the actions of his brothers are related. For example, in an early battle against the Saxons, the text states: "That day Gawein slowgh many a sarazin of the saxouns more than eny of his fellows,... And his other bretheren dide also right wele" (193). Their success is again positioned in relation to their fraternity later in the text: "Than com the thre brethern of Sir Gawein that hadde made soche slaughter of the saisnes, that alle her armours were be-steyne with blode and brayn; and whan thei were to-geder thei begonne a stronge medle, and slough so many that it was gret merveile to se" (512). The Orkney brothers prove themselves on the battlefield through their prowess, but that prowess is often related to their position as a fraternity. The close association between brotherhood and battle skill suggests that fraternity has the ability to boost military prowess. From "soche slaughter" to "gret merveil," the Orkney brothers' prowess is specifically framed

\footnotetext{
27 Gawain, as well as his brothers, do undertake individual actions throughout the Prose Merlin. However, they are consistently tied back into their positions as brothers using fraternal terms to describe them.
} 
through their unity as a fraternity. It is when they are "to-geder" that they are strongest. Even Gawain, who is singled out for his valour and deeds, is connected back to his position within a consanguine fraternity. It appears that, in Gawain's case, fraternity amplifies his own success. Gawain's place within a fraternity appears as a key element which allows him to succeed in his chivalric endeavours. He gains strength through the bonds of brotherhood through which he is commonly identified. Once again, rather than an element which holds Gawain and his brothers back, the Prose views the abilities and actions yielded from fraternity as positive forces. These characters are stronger because they are brothers, and their success is based on this relationship. In the texts examined in the first two chapters, fraternity was an obstacle for the characters; here, it is an advantage.

Just as we have seen with Ban and Bors, Gawain and his brothers function as a unit tied together through fraternity who serve to help Arthur in the establishment of his authority throughout the text. This is highlighted once again when Merlin informs Arthur that his lands are safe, primarily through the efforts of Gawain, his brothers, and his cousins who have engaged the Saxons in battle in Arthur's absence: "and drede yow not," quod Merlin, "of youre londe, for thei shull it well deffende in-to the tyme of youre comynge" (230). When asked for their names, Merlin describes them as follows: "the oon is cleped Gawein, and the tother Agravayn, and the thirde Gaheret, and the forth Gaheries, and these foure ben bretheren, and be youre suster sones, the wif of kynge loot" (230). In this description, immediately following their names, the first thing which Merlin notes is their relationship as brothers. This comes before the identification of their relationship to Arthur, though Merlin has previously identified the young men as Arthur's 
nephews. Fraternity is presented as a predominant relationship within the texts. Brothers become not only continually present but ultimately necessary in Arthur's bourgeoning realm. The shared bond of fraternity becomes central to the Arthurian community. The Orkney brothers are key to the preservation of Arthur's realm as a fraternal unit. They work together as brothers to help Arthur maintain his political power.

Bonds of fraternity become the model for chivalric community, as seen in the formation of the Round Table and the knights' identification of their fraternal love for one another. However, in the Prose, chosen brotherhood is not viewed as equivalent to, and certainly not as a replacement for, consanguine brotherhood. In fact, while lauded as an ideal relationship for men, chivalric fraternity as affective brotherhood is presented as a potentially disruptive force, and pales in comparison to consanguine bonds. This disruptive potential is evident in one particular scene in the Prose. This incident occurs when the brotherhood of the Round Table Knights is pitted against the Queen's Knights, led by Gawain, in what begins as a friendly tournament:

And whan the knygthes of the round table saugh thei turned to discounfiture, thei seiden that to-day more wolde thei do theire werste seth it is so fer forth be-fallen. Than thei toke speres, grete and rude, and putte hem in fewtre, and that is the grettest crewelte that oon may do, ffor turnement oweth to be with-oute felonye, and thei meved to smyte hem as in mortall werre. (Prose, 488)

The Round Table knights, a community that at its formation lauded brotherhood as the ideal bond between men, cannot abide the fact that their fellow knights are being dishonoured and humiliated in this tournament, as they are bested by the young Queen's 
Knights. They resort to extreme violence that is usually reserved for "mortall were." No longer is this a friendly game between two factions of knights of the same realm; it is now a battlefield in which the divide between the parties becomes akin to armies meeting in war. This is the closest the Prose texts comes to acknowledging the potential inherent conflict within fraternity. Though the Prose displays an awareness of the haunting spectacle of Cain and Abel, it nonetheless attempts to counteract the competitive nature of fraternity, offering, instead, a hopeful and valorizing view of consanguine fraternity that is at it, at its heart, based upon love and mutual obligation and loyalty. The fact that the Prose author chose to include this scene is significant, as he certainly had the option to leave it out. No such scene is present in Lovelich's tale. And though Lovelich's text is, admittedly, incomplete, the moment in which a tournament might take place is addressed and quickly shut down by Merlin, who points out the folly of fighting with each other, even in play: "For the contre al j-trowbled hit was, / and grete were of Sesoignes in mani a plas" (25815-6). As Merlin argues, the country is facing enough troubles without the knight fighting amongst themselves. The fact that the Prose Merlin engages with the potential rivalry inherent within brother groups demonstrates the author's awareness of the possibility for fraternity to cause damage and disruption in the realm. In this instance, however, it appears that the chosen fraternity of the round table is an imperfect replication of consanguine brotherhood. In the Prose, the Orkney brothers, and those who align themselves with them, are depicted as superior in their military and chivalric efforts for Arthur's sake. The affective fraternity of the knights pales in comparison to the strength and positive influence of consanguine fraternity. 
Through the tournament scene, the Prose Merlin gestures to the danger of excessive loyalty to chivalric or chosen fraternity, but while the author acknowledges that danger, it is swiftly contained while being limited to chosen brotherhood - an imperfect replication of consanguine fraternity. However, the Prose Merlin does contain one scene in which we see consanguine brothers fighting. When Gawain and his brothers accompany Lot to try and negotiate with the other rebel kings, Agravaine gets into a heated argument with Gaheris. It begins with Gaheris mocking Agravaine: "Sir, aske Agravain my brother yef he haue eny talent now to rage within these maydenes yef he hadde hem here on this playn" (535). Agravaine then insults his brother in kind, and though Lot attempts to turn the conversation to other matters, the quarrel of the two brothers escalates and becomes physically violent:

and than be-gan Agravain sore to wrathe, and seide he sholde it a-beyen, and hilde a tronchon of a spere in his honde, and smote Gaheries on the helme that it fly all to peces, and Gaheries remeved not but suffred; and Agravain recouered and smote twys or thries, so that nought of the tronchon lefte in his handes, and his brother Gueheret ne hys fader cowde hem not so departe, but euer he ran vpon hym as he myght from hem ascape. (536)

Gawain almost immediately intercedes when he returns to the scene, drawing his own sword. Gawain "smote hym with the pomell of his swerde vnder the temple that he fill from his horse to the erthe so astoned that he wiste not where he was" (537). Before the fight can continue, Gaheriet points out that Gaheris did provoke Agravaine and argues that Gawain has proven his point with the one hit. King Lot then speaks up, threatening to 
take away their weapons and leave them "in myddell of the felde like lurdeynes" (538). While Agravaine's actions are, of course, troubling, the fight between these two brothers occurs significantly in the middle of the woods and does not put any of Arthur's power or authority at stake. In fact, Agravaine, with his anger and willingness to harm his brother, is an example of a character in the Prose who does not have mastery over his own emotions. Agravaine's lack of self-control leads him to outright attack his own brothers, a small but significant scene that suggests the Prose author is fully aware of the potential rivalry which exists between brothers. Agravaine's lack of self-governance is demonstrated through the anger and violence directed at Gaheris. Gawain's own violent actions are justified, being in the defense of Gaheries. While the brothers, in this instance, do fight, and fight violently, their feud does not represent a divide in the main armies at Arthur's disposal. Rather, in this moment they are acting as individual brothers who tease one another and grow angry because of that teasing. Instead of representing a danger to the stability of the polity, the scene reads as a domestic scene of brotherly squabbling. The Prose author recognizes the potential for violence and anger between brothers, but contains it within a domestic scene, rather than allowing it to have repercussions for the realm.

While acknowledging the potential for fraternal bonds to become excessive and disruptive, the Prose focuses primarily on the positive attributes of fraternity. It demonstrates the nobility and importance of consanguine brotherhood through several speeches made by characters faced with the potential of losing a brother. These characters voice laments and make oaths when they believe one of their brothers to have been slain. One example of an oath of revenge made by a brother occurs in the battle against the 
Saxons outside of Logres. Gaheries, believing Gaheret to be dead, makes a vow to revenge his brother: "And whan Gaheries saugh the sarazin thus fleynge, he swore be god that he sholde neuer cesse ne leve hym, for playn ne wode, till he was a-venged of his brother deth" (Prose, 194). A similar oath is made in Lovelich's version of the text: thanne swor Gaheriet anon there be God \& be his blessed modir dere that zif euere he myhte armes welde to ben a knyht and beryn a schelde, that he scholde neuere jn place abyde nethir day ne nyht, that he nolde ryde vppon the hethen, avenged til that he be of his brotheris deth, ful certeinle. (Lovelich, 13181-8)

Both authors stress that the death of a brother is so devastating that the remaining brother would be willing to spend the rest of his life seeking revenge for the death. The oath is also more than a statement of intention, as in both texts it is an oath made "be God." Gaheries is willing to dedicate his life to the revenge of his brother. The importance of brothers is also heightened through the swearing of a different sort of oath, as is evident when Gawain fears that Gaheries might be dead, seen in both the Prose and Lovelich: "Ha! seinte Marie Virgin, and moder of Jeshu criste, ne suffre not that I lese my brother, for than myn herte shall neuer be gladde; and yef I hym thus lese, shall ther neuer shelde hange a-boute my nekke." (Prose, 195)

anon he preide to hevene king 
and to blessed marye, his modir jn fere,

that he scholde not lesen his brother dere.

"For zif $\mathrm{j}$ hym lese jn this degre,

joyful jn herte schal $\mathrm{j}$ thanne neuere be;

and zif $\mathrm{j}$ thus lese hmy jn this feld,

abowtes my nekke neuere hangen schal scheld!" (Lovelich 13250-56)

Gawain vows that he will not take up arms as a knight if he has lost his brother in the battle, once again tying fraternity to chivalric honour. If Gawain has allowed his brother to be killed, he does not feel he deserves to be knighted. His chivalric honour becomes void in light of his perceived failure to protect his brother. Just as Gaheries makes a vow to dedicate the rest of his life to revenge, Gawain makes a similar vow, stating that he would not be worthy of being knighted.

The loss of a brother is so profound that the remainder of one's life apparently can, and should, be dedicated to somehow honouring that death. And it is not just the Orkney brothers who view the death of a brother so drastically. Ban also responds with an extreme sentiment when he believes Bors to have been killed:

Whan the kynge Ban vndirstode Merlin, all his body trembled, and a-noon asked and seide, "Ha! sir, tell me whiche wey it is, for yef he dye shall I neuer haue ioye in my lyve." (Prose 332)

Whanne kyng Ban herde Merlyn so seyn, Al his body for sorwe qwook, in certeyn. "ha, goode Sire Merlyn, now telle ze me 
jnto what partye that he may be!

For zif he be so ded or slayn thore,

My joye hit is doon for euermore.” (Lovelich, 22941-6)

While Ban makes neither a boast indicating that he will spend the remainder of his days seeking revenge nor an oath that he will give up an important aspiration, such as becoming a knight, he does state that he will never again be happy if it is revealed that his brother has died. In all three incidents, the threat of losing a brother is a fundamentally devastating and potentially life-altering event. Both the Prose and Lovelich's text establish fraternity as only one of the most fundamental and important relationships for both individuals and the realm as a whole. Brothers are pivotal to the polity and to each other. In Malory, which explores not only the rise of Arthur's power but also the fall, the fundamental nature of fraternal relationships becomes problematic rather than helpful when the obligations associated with fraternity become obstacles to overcome for the good of the kingdom. However, here in the Prose Merlin and Lovelich's work, brotherly bonds are a powerful positive force within Arthur's realm. These bonds are responsible for the establishment of Arthur's reign.

\section{Conclusions}

Throughout the Prose Merlin and Lovelich's Merlin, the authors cultivate a vison of the Arthurian world in which brotherhood is represented as a necessary social bond, and one which becomes a model for ideal male homosocial ties. Readers of the Prose and Lovelich are continually reminded of these characters' fraternal relationships. As such, 
terms of fraternity act as one of the key methods of characterization and description which establishes chivalric honour and potential. The foundation of Arthur's reign and his ability to gain power and land both depend on the aid of brother-groups. Arthur's right to rule, before he is even born, is won by his father and uncle. Uther and Pendragon work together to regain their lands from Vortigern, and it is as brothers that they are successful. Even after Pendragon's death, Uther's relation to him is solidified when Uther takes on his brother's name. Bors and Ban, the brethren kings, are presented as brothers who help Arthur establish his realm. They are key allies who fight alongside him to quell rebellions throughout the land. The Orkney brothers preserve and maintain Arthur's power in the realm, even in his absence. Consanguine fraternal loyalty is a sign of chivalric prowess and one which is imperfectly emulated by the very knights chosen to sit at the Round Table during Uther's reign. It is not the chosen bonds of the Round Table which push Arthur to succeed, but the efforts of the fraternal consanguine groups of Ban and Bors and the Orkney brothers. Arthur's rule as a king begins successfully because of the efforts of Uther and Pendragon, the support of the brethren kings, and the valour of the Orkney brothers.

In both texts studied here, fraternity is essential for the Rise of Arthur. Rather than presenting fraternity as inherently problematic, these authors envision a world in which brotherhood can be an overall positive force for the good of the kingdom. In both the Prose and Lovelich's Merlin, fraternity is at the foundation of a kingdom, not its destruction - unlike the conflict between Eteocles, Polymyte and Thebes seen in the previous chapter, and unlike Malory's adaptation of the Arthurian story. And while the Prose author does recognize and acknowledge the potential for fraternity to be fraught 
with jealousy and anger, that threat is mitigated and contained. Rather than be an inevitable facet of the brotherly bond, as we have seen in other texts, fraternal rivalry becomes something which can be controlled, avoided, and overcome. The Prose author, especially, creates a text which presents fraternity as a plausible foundational homosocial bond which can be used to establish and maintain the political security of the kingdom. In the next chapter, I examine the ways in which Arthurian fraternity is not always a positive element in the text, and how brotherhood and the obligations associated with it present an obstacle to the peace and unity of the Round Table. Thus, the decision of both the Prose author and Lovelich to highlight fraternity as a positive and necessary relationship in their tales is all the more striking when it is clear that it is a deliberate choice, not merely one inherited from their sources, and demonstrates the potential for alternative understandings of Arthurian fraternity. 


\section{Chapter Four: Le Morte Darthur: The Fall of Arthur}

Beginning with the tragic double fratricide of Balin and Balan and ending with Gawain's quest for vengeance after the murder of his brothers, fraternal relationships in Sir Thomas Malory's Le Morte Darthur frame Arthur's reign as king in tragedy. In spite of Arthur's attempts to build a fellowship of knights based upon prowess and chivalric honour, ties of blood constantly infiltrate the Round Table, and neither the reader nor the characters within the text are able to escape the negative impact of these fraternal bonds. Whereas in the Prose Merlin fraternity is necessary for the foundation of Arthur's realm, in Malory's version of the Arthurian story fraternity is represented as an inescapable and intrinsic part of Arthur's eventual fall. The Prose Merlin author, as well as Henry Lovelich, presented fraternity as a positive force which contributed to Arthur's rise to power. As in the Cain and Abel plays, or Lydgate's Siege of Thebes, in Malory, the potentially dangerous nature of fraternity is once again at the forefront. However, unlike the previous texts, in Le Morte Darthur it is not the nature of rivalry inherent in brotherhood that is the problem; rather, it is the danger of allowing the obligations of fraternal loyalty to supersede everything else. Throughout the Morte, fraternal loyalties are contrasted with other social and political obligations. The story depicts the whole of the Arthurian tale, beginning with Arthur's conception and ending with the aftermath of his death. Malory's text is a collection of both repurposed and reworked source material as well as original additions to the overall tale of Arthur. ${ }^{1}$ In Malory, brothers play a

\footnotetext{
${ }^{1}$ My focus in this chapter will be on the text as it is presented in Malory's version of the tale and, as such, I do not attempt to outline all of Malory's sources, except for when his deviations are significant to his
} 
predominant role in the governing of Arthur's kingdom. However, unlike the Prose Merlin, in which brothers helped establish Arthur's kingdom, in Malory brothers and the loyalties of fraternity aid in the downfall of Arthur's reign. Malory's text demonstrates the power of fraternity, not to build up Arthur's realm, but to divide it. Fraternity in the Morte is an ever present and ever powerful relationship that the characters, even those who try to overcome fraternal obligations which are at odds with the kingdom's best interests, cannot ignore or escape entirely. Thus, Malory engages with conflicts between fraternity and political governance, and fraternity and self-governance. In contrast to Cain and Abel, and Eteocles and Polymyte, the characters in the Morte demonstrate a lack of self-governance through their inability to overcome the excessive demands of fraternal loyalty, rather than through an unwillingness to uphold it.

In this chapter, I focus on key episodes in the Morte in which tragedy results from characters' inabilities to avoid or overcome the obligations of fraternity and investigate how this unavoidable fraternity plays a major role in the entire downfall of Arthur's kingdom. I explore the way in which Malory's tale frames fraternal loyalty as something from which neither individual brothers nor the king himself can escape. Fraternity and fraternal obligations are a driving force for major events within the narrative. The inescapable nature of fraternity in this text is first evident in the story of Balin and Balan - an example of fratricide which occurs not out of malice, but as a result of hidden identities. I then turn my attention to the Orkney brothers, as they are the most prominent

presentation of brotherhood. For information on Malory's sources, see Terence McCarthy, "Malory and His Sources," in A Companion to Malory, eds. Elizabeth Archibald and A.S.G. Edwards, 75-95 (Cambridge: D. S. Brewer, 1996) and Ralph Norris, "Malory and His Sources," in The New Companion to Malory, eds. Megan G. Leitch and Cory James Rushton, 32-52 (Cambridge: D. S. Brewer, 2019). 
set of brothers in the text, and survey how these brothers are ultimately unable to escape from the bonds of brotherhood, to the detriment of the entire realm. I begin this investigation with Malory's introduction of Gareth as an example of the "Fair Unknown," and as a character who attempts to escape from the confines of his own fraternity. Throughout Gareth's tale, he attempts to make a name for himself that is not based upon his family but rather upon his own prowess. Yet, even in this instance, he is unable to escape from the fraternity which runs throughout the Morte. Gareth gains his own reputation and his own power through his encounters with a series of brothers. He also must fight against his own brother, Sir Gawain, in a scene reminiscent of the tragic battle between Balin and his brother. Gareth gains governance over his own men and lands, and yet, as will be examined, cannot escape fully from the actions of his brothers. I then continue by inspecting key moments in which the actions of brothers affect the stability and unity of Arthur's realm, which proves unable to withstand the force of fraternal loyalty, as it plays a major role in dividing the once united fellowship of the Round Table.

In Malory's text, the constraints of brotherhood become unavoidable for characters and readers alike. While the significance and predominance of kin issues in this text has been well established in scholarship, I argue that excessive fraternity is utilized in Malory especially as a destructive force, rather than a tool for positive selfgovernance. This argument builds upon previous scholarship in the field. Dorsey Armstrong, for example, points out that “the Morte Darthur, in Malory's hands, becomes a story that in one respect is dominated by kin loyalty and the vengeance enacted in blood 
feud." I I expand upon this argument by suggesting that not only is fraternity a prominent element in the text, but it is one that Malory uses as a tool in order to explore issues of both self and political governance. Malory's text pushes fraternity to its limits to scrutinize how this inherently complicated relationship can have implications far beyond the interpersonal. Fraternity is not just present; it is entirely unavoidable. In the Morte, because of the powerful role brothers play in the political landscape, the inability to ignore fraternal obligations specifically threatens to dismantle the very same powerbase that was upheld by fraternity in the Prose Merlin. Through a careful consideration of consanguine fraternity in the Morte, we gain a better understanding of Malory's anxieties concerning the possibility of political stability in a world dominated by fraternal obligation.

\section{Fraternal Terminology}

Just as within the Prose, fraternal terms are used frequently throughout Malory's text. Terms such as "brothir," "bretherene," or some variation thereof appear in the Morte over four hundred and fifty times. The usage of the terms ranges from direct forms of address, to identifications of heritage, to general descriptors of a set of characters. ${ }^{3}$ However, while the Prose Merlin also included an abundance of fraternal terms, the effect in both texts differs greatly. In Malory, fraternal terms are used more often when linking characters to the obligations of their fraternity. On the other hand, the Prose

\footnotetext{
2 Dorsey Armstrong, "Malory and Character," in A New Companion to Malory, eds. Megan G. Leitch and Cory Rushton (Cambridge: D. S. Brewer, 2019), 145.

${ }^{3}$ For a breakdown of the individual spellings and terms, see Tomomi Kato, ed., A Concordance to the Works of Sir Thomas Malory (Tokyo: University of Tokyo Press, 1974), 242-49, 1615.
} 
repeatedly draws the connection between characters' ability to help Arthur and their place in a fraternal group. One clear way in which Malory's conception of fraternity differs from the Prose Merlin's is in the application of fraternal terms to King Ban and King Bors. As discussed in the last chapter, in the Prose Merlin these characters, who were repeatedly referred to as brothers, or the "bretheren kynges," were pivotal in Arthur's war against those who still opposed his rule. Merlin's introduction of Ban and Bors in the Morte immediately links the characters as brothers; for example: "I shal telle you," said Merlyn, "myne advys. There ar two bretheren beyond the see, and they be kynges bothe and merveillous good men of her handes; and that one hyght Kynge Ban of Benwic, and that other hyght Kynge Bors of Gaule, that is Fraunce" (15.2-5) This scene echoes the language of "bretheren" which is used by the Prose author, rather than "cousins" used by Lovelich. Like the Prose author, Malory first introduces the characters unambiguously as brothers; however, unlike in the Prose and Lovelich, in the Morte readers are not constantly reminded of the fraternal bond between them.

While in the Morte, Ban and Bors do venture to England to help Arthur in his wars against the eleven kings who stand against Arthur's rule, their role in the narrative is much reduced, as is the number of references to their brotherhood. While this is partly because Malory's text covers much more of Arthur's life, spanning from before his birth to after his death, the fact remains that when Ban and Bors are active in the text, they are associated with fraternal terms only a handful of times. In fact, Ban and Bors are more commonly referred to either simply by their names or as the "two kynges." Following their first introduction, the brothers are called the two kings repeatedly, rather than the 
"brethren kings" as was common in the Prose Merlin. ${ }^{4}$ The two men are not referred to as brothers again until the battle against the kings who oppose Arthur's rule is well underway. Lot, having recognized Ban, informs his allies of the other's identity: "we must be discomfite, for yondir I se the most valiante knyght of the worlde, and the man of most renowne, for such too brethirne as ys Kynge Ban and Kynge Bors ar nat lyvynge" (26.6-9). While Malory does not focus on the brotherhood of Ban and Bors, he still recognizes it as an important element of their characterization. They are recognized as brothers by others in the text, such as Lot. The fraternal bond between the two men is a part of the characterization of Ban and Bors, but it is not their defining or most important feature in Malory's version of their role in aiding Arthur in his rise to power.

One significant use of the term brother and its association with Ban and Bors occurs when, in the middle of battle, Ban is unhorsed and Arthur brings him another: "Fayre brother, have ye thys horse, for ye have grete myster thereof, and me repentys sore of youre grete damage" (27.15-16). Arthur uses the term as a means of connecting himself and Ban as allies in the war against the eleven kings. Arthur uses the term to create the bond between them, offering Ban the opportunity to accept the deepened nature of their alliance. The use of fraternal terms of address harkens back to Cain and Abel, as in the plays, Abel seeks to affirm the bond he shares with Cain. It will also be utilized by the characters in Gamelyn, explored in the next chapter, to manipulate the expected obligations and emotions one should feel towards a brother. Here, however, there is no sense that Arthur is attempting to manipulate Ban; rather, he is extending the offer of kinship based upon the idea of fraternity, seeing this relationship as an ideal bond

\footnotetext{
${ }^{4}$ See, for example, $15.9,15.18,16.7,16.31,16.35,17.5,17.22$, and 18.10
} 
between two men. The fact that Arthur utilizes "brother" as a term of address to create or reinforce the bond between them demonstrates the potential for fraternity to be a model homo-social relationship in Malory's text. Malory acknowledges that brotherhood can be viewed as an ideal bond, valorized by the characters within the tale. However, the potential for brotherhood to be a force of good in the realm is never fully realized and is, in fact, challenged repeatedly as the rest of the Morte unfolds.

While the example of Ban and Bors is one key variation in the use of fraternal terms between the Prose and the Morte, it is not the only, or even the most significant one. Whereas within the Prose fraternal terms are, for the most part, spread out throughout the text, occurring whenever the text is focused on any description of the brotherly groups, Malory's use of fraternal terms tends to cluster into episodes in the text when characters attempt to overcome the powerful and potentially destructive demands of fraternity. These episodes, such as "Sir Gareth of Orkney" which will be examined in detail shortly, contain a large portion of Malory's overall usage of the terms associated with fraternity. While these terms are also utilized throughout the text as a way to reference particular characters, they come to the forefront of the narrative in the episodes where fraternity presents an obstacle for the characters to overcome, either for selfimprovement or the benefit of the kingdom. In this way, the readers, just like the characters, are unable to avoid the domination of fraternity in Malory's vision of the Arthurian world.

\section{Fratricide in Malory}

The earliest indication that the presence of fraternity is unavoidable in Le Morte Darthur is the accidental fratricide of the brothers Balin and Balan who are introduced 
into the text before their adventures, during the war against the eleven kings. Merlin prophesises that "thes eleven kyngis shall dye all in one day by the grete myght and prouesse of armys of two valyaunte knyghtes" whose "namys were Balyne le Saveage and Balan hys brothir" (32.28-30). These characters, who have an important role to play in the early years of Arthur's reign, are introduced specifically as brothers. And while it may appear that Malory, in this instance, is aligning the ability of these characters to help Arthur with their fraternity, it quickly becomes evident that their fraternity is less a positive attribute than it is a problematic bond within a world filled with men whose purpose in life is to fight and kill. Appearing in the first book of the Morte, "King Uther and King Arthur," the tale of "Balyn le Sauvage" is one of the first adventures to be related following the crowning of Arthur and his successful wars against the rebel lords who initially refused to accept him as their king. The tale begins with a young maiden appearing in the court with a challenge: she carries a sword at her side, but she can "nat be delyverde of thys swerde but by a knyght, and he muste be a passynge good man of hys hondys and of hys dedis, and withoute velony other trechory and withoute treson" (48.1-3). Arthur and the other barons are all unable to remove the sword from the scabbard. However, Balin, who has just been released from prison for killing one of Arthur's cousins, asks if he, too, might try his hand at removing the sword. When he is successful, the maiden praises him, but demands that he return the sword. Balin refuses, and the maiden warns him of the consequences of this choice: "ye ar nat wyse to kepe the swerde fro me, for ye shall sle with that swerd the beste frende that ye have and the man that ye moste love in the worlde, and that swerde shall be youre destruccion" (50.1-4). This does not persuade Balin to return the sword, and he decides to "take the aventure" 
(50.5). ${ }^{5}$ Following the maiden's departure from the court, the Lady of the Lake appears, asking Arthur for Balin's head because he slew her brother (51.9-12). Before Arthur can resolve this issue, Balin recognizes the Lady of the Lake as the woman responsible for the death of his mother and cuts off her head in court. Arthur is understandably displeased and banishes Balin from the court. Balin is soon joined by his brother, Balan, who promises to journey with him: "I woll well," seyde Balan, that ye so do; and I woll ryde with you and put my body in adventure with you as a brothir ought to do" (55.3032). Balan's claim here heightens for readers the significance of their fraternity. The remaining tale depicts the adventures of Balin, though he and Balan become separated, and it culminates in his fighting, unknowingly, against his own brother.

Fraternity is present throughout this tale. It is first mentioned when we learn that Balin killed the Lady of the Lake's brother, and her desire for vengeance for this death is pivotal in the plot which will end with the accidental double fratricide of Balin and Balan. As Carolyne Larrington suggests, the origins of the fratricide of Balyn and Balan begin with the sword Balyn obtains from the maiden, as we learn that it was forged so that the maiden could be revenged upon her brother. Merlin informs Arthur that the damsel who brought the sword sought vengeance against her own brother after discovering he had slain her lover: "And whan thys false damesell undirstoode this she wente to the Lady Lyle of Avylion and toke hir hys swerde, and besought hir of helpe to be revenged on hir owne brothir ... and with that swerde he sholde sle hir brothir" (53.10-17). Larrington claims that the "fate of the two brothers, both in their French and English versions,

\footnotetext{
${ }^{5}$ For a detailed discussion of the nature of the word "adventure" in this tale, see Jill Mann, "Taking the Adventure': Malory and the Suite du Merlin," in Life in Words: Essays on Chaucer, the Gawain-Poet, and Malory, ed. Mark David Rasmussen, 243-274 (Toronto: University of Toronto Press, 2014).
} 
originates in the clash between the damsel's brother and her lover" and that "sibling hatred, generated in the sword-bearing damsel through her brother's killing of her lover, are projected on to Balin and Balan, significantly, the only fratricides in the Morte Darthur." As Larrington rightfully notes, the sword which Balin carries is tainted from the beginning with the purpose of fratricide. Balin, in accepting the sword, unwittingly accepts the possibility of fratricide in his own life. This is not to suggest that Balin's success in removing the sword from the scabbard is the direct cause for the death of his brother, but rather to argue that fraternity in Malory is ever present as a dominant relationship within this Arthurian world, even when it is not recognized. ${ }^{7}$

However, while I agree that the fratricide of Balin and Balan begins with the illfated sword, Larrington's claim that this represents the only fratricide in the Morte is not entirely accurate. There is one other example of successful and deliberate fratricide, which has often been overlooked in scholarship. In "Sir Tristram de Lyones: The Second Book," King Mark of Cornwall kills his own brother, Prince Bodwyne. Mark is "wondirly wrothe that his brothir sholde wynne suche worship and honour" (501.18-19). Mark views Bodwyne as his direct competition and is angered when Bodwyne is better loved and worshiped than he is himself. This rivalry, which harkens back to similar issues of jealousy in the Cain and Abel plays, demonstrates the fact that brothers can be one's closest ally or one's biggest competition. Malory is clear in labelling Mark's deeds as treacherous, calling Mark “the falsist traytour that ever was borne” (501.26). Mark’s

\footnotetext{
${ }^{6}$ Ibid., 70. For a detailed exploration of the similarities and differences between the French Suite du Merlin's and Malory's versions of the Balin story, see Mann.

${ }^{7}$ For a full discussion of cause and effect in the Balin story within Malory, see Robert L. Kelly, "Malory's 'Tale of Balin' Reconsidered," Speculum 54, no. 1 (1979): 85-99.
} 
actions, both here and throughout the rest of his appearances in the Morte, are unequivocally the actions of a villainous king, as he attempts, numerous times, to have Sir Tristram, his own nephew, slain. Thus, when Mark calls for Bodwyne and his family to visit, the readers are not surprised when Mark then slays his own brother: "And therewith he stroke hym to the herte wyth a dagger, that he never aftir spake worde" (502.10-11). This fratricide, unlike that of Balin and Balan, is entirely deliberate and demonstrates Mark's villainous nature. The death of Bodwyne at his own brother's hands is used to amplify Mark's treacherous behaviour, demonstrated throughout the two books of Sir Tristram, and to contrast it with the tragic deaths of Balin and Balan at their brother's hands. It is also an example of the ongoing contrast between Mark and Arthur throughout the Morte. Malory uses Mark's lack of self-governance, his anger, and jealousy as proof of his unsuitability as a king. Just as Eteocles's leadership as king is criticized because of his fraternal behaviour, Mark's murder of his own brother is reflective of his own problematic governing practices. The fratricide committed by Mark reveals Malory's awareness of the inherently fraught nature of fraternity, and the dangerous potential for such a relationship to be more harmful than helpful in the governing of the political realm.

Unlike the case of Mark and Bodwyne, the fratricide of Balin and Balan is neither premeditated nor deliberate. The brothers encounter one another in a battle while neither is wearing his own armour or carrying his own shield so that he might be recognized by his brother. It is not until after the brothers have fought for some time, both inflicting mortal wounds upon each other, that Balin asks the other his identity. Balan responds, not only with his name, but unknowingly with their affiliation: "My name is," said he, 
"Balan, broder unto the good knyght Balyn" (72.25-26). Balin is understandably distraught and removes his brother's helmet. He laments their tragic encounter: "O Balan, my broder! Thow hast slayne me and I the, wherfore alle the wyde worlde shalle speke of us both!" (72.31-3). Balan recognizes the gravity of what has happened, not just for his own grief, but for their reputations. To slay one's own brother, as King Mark did, is a terrible act. Balin and Balan are buried together, requesting that their grave be marked with an epitaph that describes the fact that in this place "two bretheren slewe eche other" (73.25). These brothers operate in a world full of both violence and fraternity, and there is always the potential for those two things to clash. ${ }^{8}$ Balin, from the moment he withdraws the sword in court, is unable to escape from the violence of Arthurian world to the detriment of his fraternal relationship with Balan. Though neither brother intends to commit fratricide, the gravity of the deed is represented for all to see at their grave. Unlike Mark's murder of Bodwyne and Cain's murder of Abel, this fratricide is a not a result of jealousy and anger, but it is still a result of poor self-governance. In the case of Balin, his lack of self-governance is a result of his desire for renown and his prideful belief that as a knight he has a right to claim the adventures which he encounters. Balin and Balan's mutual fratricide reflects the potential of the chivalric and knightly life to conflict with family relationships. The deaths of these two brothers signal the social costs of fratricide, even when it is committed unwittingly, suggesting the omnipresent danger of fraternal rivalry.

\footnotetext{
8 The dangerous potential for brothers to encounter one another unknowingly in this world will be replicated and evoked when Gareth and Gawain unwittingly encounter one another, as will be discussed in the next section of this chapter.
} 
Malory's Balan and Balin are not the only example of brothers who accidental slay one another in medieval literature, as it appears as a trope in other texts as well, such as Tydeus's accidental murder of his own brother in the Siege of Thebes. But Malory utilizes this literary plot device to demonstrate early on in the Morte just how difficult it is for the characters to avoid fraternity, even when it is least expected. In Larrington's discussion of the "accidental fratricide topos," she argues that "[n] arratives which deal directly with the death of the beloved or the unrecognized brother at his own brother's hands allow the exploration of the murderous fantasies generated by sibling rivalry as crystallized in the brother's killing." She suggests that "these narratives are multivalent in their exploration of unacknowledged sibling rivalry, loss and survivor-guilt. They also permit imaginative rehearsal and resolution of the fear of fratricide." ${ }^{10}$ Within the Morte, Malory exploits the occurrence of accidental fratricide to establish the inevitability of fraternity within his text. Balin, as the first representation of a questing knight who, though banished, begins his adventures in Arthur's court, represents the inescapability from the confines of fraternity within the text. Brothers, and the obligations one has towards said brothers, permeate the entirety of the Morte, and are particularly relevant in key episodes within the text. The story of Balin may be the first of these episodes, but its tragic end foreshadows the devastating role fraternity will play in the remainder of the Morte.

\footnotetext{
${ }^{9}$ Carolyn Larrington, Brothers and Sisters in Medieval European Literature (Woodbridge: York Medieval Press, 2015), 9. For a further exploration of sibling rivalry in both England and Iceland, see W. I. Mitchell, "Choosing the Avenger: Some aspects of the Bloodfeud in Medieval Iceland and England," Law and History Review 1, no. 2 (1983): 159-204.

10 Larrington, 69.
} 


\section{Fraternity and the Fair Unknown}

The Orkney brothers (Gawain, Gaheris, Aggravaine, Gareth, and Mordred) are by far the most prominent brothers in the Morte, and they play a significant role in the overall narrative and, more importantly, in the fall of the kingdom. Their fraternity, and the loyalties that fraternity demands, help set the war between Arthur and Lancelot in motion, signaling the final and permanent divide between the Knights of the Round Table. In both this and the following section, I consider the way in which Malory examines the fraternity of the Orkney brothers as both central but also, significantly, inescapable, within the Morte as a whole. Of the over four hundred and fifty fraternal terms within the text, over one fourth of those- just over one hundred and twenty-refer directly to the Orkney brothers. ${ }^{11}$ The majority of those terms appear in two books: "Sir Gareth of Orkney" and "The Morte Arthur," and my analysis in this and the following section will focus on these books. I consider the way in which Gareth attempts to distance himself from this fraternity but is ultimately unable to escape from the consequences which arise when brotherhood demands unwavering loyalty. The Orkney brothers, especially Gawain, have a powerful role at court as they are Arthur's nephews. These brothers help set the final events of the Morte in motion, forcing open the fissure which had been threatening to undo the Round Table fellowship for some time. The brothers have an important but tragic influence over Arthur and his governing decisions which leads to the destruction of his realm and the death of Arthur himself.

\footnotetext{
11 The brothers who are referred to second most often are Lancelot's kin, with almost seventy-five terms associated with these characters. However, the text also uses the term "cousin" for the relationship between Lancelot and Bors, for example. The text generally refers to Lancelot's kin or kinsmen, whereas Gawain and his brothers are often identified specifically as brothers.
} 
One of the ways in which fraternity plays a significant role in connection with the Orkney brothers in Malory is evident in his two adaptations of the "Fair Unknown" tale types: "Sir Gareth of Orkney" and his version of the story of "La Cote Male Tayle," located in the first book of Sir Tristram. ${ }^{12}$ Several parallels exist between both these tales and the tradition of the "Fair Unknown" with which Malory was likely familiar-though for my purposes here I focus on the example of Sir Gareth. In the "Fair Unknown" tale, a young man appears in court, wishing to be knighted. However, his family and parentage are either unknown to him or concealed by him. The young man must prove his worth through his actions, rather than by relying upon his family name to award him a position of honour. The young man asks to be granted a quest and is often ridiculed by the maiden who first came to the court, looking for a knight to aid her. She is upset that she has not been given a proper knight, but instead one who is untried and of little renown. She spends most of their journey mocking him and diminishing his accomplishments, which only serves to motivate the knight to continue to prove himself, even if he is of unknown lineage. Of course, his nobility and worthiness are reaffirmed when it is revealed that he is connected to some significant member at court.

"Sir Gareth of Orkney" shares with the "Fair Unknown" tradition a discrepancy between the protagonist's lack of familial connections and his encounters with kin-

\footnotetext{
12 For discussion of the lack of a known source for the Gareth material, as well as its potential folklore origins, see Judith Lanzendorfer, "Folklore motifs and diminishing narrative time as a method of coherence in Malory's Morte Darthur," in Romance and Rhetoric: Essays in Honour of Dhira B. Mahoney, eds. Georgiana Donavin and Anita Obermeier, 235-248 (Turnhout: Brepols, 2010); R.H. Wilson, "The 'Fair Unknown' in Malory," PMLA 58 (1943): 1-21; and Barbara Nolan, "The Tale of Sir Gareth and the Tale of Sir Lancelot," in A Companion to Malory, eds. Elizabeth Archibald and A. S. G. Edwards, 153-181 (Cambridge: D. S. Brewer, 1996).
} 
bonded knights. ${ }^{13}$ The Middle English Lybeaus Desconus is one such version of the "Fair Unknown" trope, and one which appears to have had some popularity in the fifteenth century, with five of the six known manuscripts dating from this period. ${ }^{14}$ Lybeaus Desconus highlights the importance of kin relationships as in this version of the tale, the protagonist is identified by name and parentage: "His name was Sir Gyngelayne, / Gotten he was of Sir Gawenye" (7-8). However, without knowing that his father in in fact Gawain, the young Lybeaus cannot take advantage of his heritage to obtain his rightful position as a knight at Arthur's court. He is forced to navigate knighthood without the guidance of either a father or brothers. In spite of this, Gawain appears to have some instinctual affinity for the unknown young man. While several knights in the Lambeth manuscript version of Lybeaus rush to help knight the protagonist, it is specifically Gawain who takes the initiative (240-4), and it is explicitly "Syr Gawyn, his owe syre" who gives Lybeaus his sword. (Lambeth 252) Gawain's blood connection to Lybeaus is emphasized in the moment he arms his son with his weapon. In the Naples manuscript, this connection to Gawain is heightened even further, as Gawain teaches the young man how to be a knight: "Aftur, him taught Gaweyn, / With strenghe in the pleyn, / Poynt of

\footnotetext{
${ }^{13}$ Arnold Sanders argues that "Malory mixes and disrupts narrative conventions common in 'Fair Unknown' tales by blending them with conventions common to poems of the 'Gawain'-romances, a popular tale type not often associated by Malory scholars with this narrative's structure." See Arnold Sanders, "Sir Gareth and the 'Unfair Unknown': Malory's Use of the Gawain Romances," Arthuriana 16, no. 1 (Spring, 2006): 34.

${ }^{14}$ London, British Library, Cotton, MS Caligula A.ii (c. 1400); Naples, Biblioteca Nazionale, MS XIII.B.29 (1457); London, Lambeth Palace, MS 306 (1460); Oxford, Bodleian Library, MS 6922 (or Ashmole 61) (c. 1490); London, Lincoln's Inn, MS 150 (c.1400); and London, British Library, MS Additional 27879 (the Percy Folio) (c. 1650). See Eve Salisbury and James Weldon, eds., Lybeaus Desconus (Kalamazoo: Medieval Institute Publications, 2013), 6-8. My study focuses on the two manuscripts reproduced by Salisbury and Weldon in their edition: Naples, Biblioteca Nazionale, MS XIII.B.29 and London, Lambeth Palace, MS 306. I have chosen to cite this edition as it presents, in a side-by-side manner, the tale from two manuscripts which are believed to have been composed in the mid-fifteenth century, relatively close to the date in which Malory would have composed Le Morte Darthur.
} 
knyghtis play" (91-3). Lybeaus and Gawain are unaware of their familial connection, but the text emphasizes the role of father which Gawain is meant to play by having him act as a guide in Lybeaus's knightly education.

Once he has received both the equipment and instruction of a knight, Lybeaus sets out from the court to prove himself worthy of the title. In his adventures, Lybeaus encounters not one, but two sets of brothers. The first of these brethren are the nephews of Sir William Delaraunche, whom Lybeaus defeats in a joust (Lambeth, 336-392). After leaving Lybeaus, William encounters three men who "weren his syster sonnes free" (412). The princes are angered by their uncle's defeat, and vow to challenge Lybeaus themselves:

Thou shalt awroken bee

Sertys withoute fayle!

Hym agayne vs thre

And though the traytour be wrothe

We shall him assayll.” (442-50)

Lybeaus, with no known family at this time, is unable to access the same type of natural support network upon which William is able to rely. William does not need to travel far to find young men who seek to support and avenge him specifically because of their shared blood. William has not even had to seek out his nephews - he comes across them while on his way to Camelot at Lybeaus's command.

United and presumably strengthened through their kinship bonds, William's nephews set out to avenge their uncle — not as individuals, but as a fraternal unit. When 
they encounter Lybeaus, it is unambiguously as a set of brothers who each function as part of a whole, attacking in succession to one another. Each is introduced into the fight through his position in the sibling dynamic:

The eldest brother can bere

To Sir Lybeus a spere:

Gower was his name; (484-86)

The medyllest brothere beheld

How his brother in the felde

Had lorne bothe mayne and myght.

He smote, as it is tolde,

Syr Lybeous in the shelde

With his spere full right. (502-7)

The yongest brother full yerne

Upon a stede full sterne

As egir as eny lyon,

Hym thought his body can bren

But he myght, also yerne,

Ber Lybeous downe. (514-19)

Lybeaus encounters three men, who specifically share a fraternal bond of loyalty. Whereas Lybeaus has no support to fall back upon, they can draw upon their fraternal bond for support. When one brother fails, the next steps in. Lybeaus does not have this 
luxury, as he must rely upon his own strength and skill to overcome his opponents one after another. There is a discrepancy between Lybeaus's own situation and the nature of the challenges he must overcome, relating directly to kin relationships. This dissonance is further heightened when Lybeaus encounters Irayne and Mabon, two brothers who have taken the Lady of Synadon prisoner through enchantment. Lybeaus vows he will fight against these brothers and "hewen in the playne / the hedys by the chynne" (1795). The "Fair Unknown" tale is one which introduces a character who is separated from kin support and yet must directly confront those who function specifically as brothers. The protagonist must face exactly that which he is most notably lacking: kinship support.

Malory makes use of the discrepancy found in the "Fair Unknown" in "Sir Gareth of Orkney," heightening for readers the abundance of fraternal bonds within his text. In "Gareth" in particular, Malory reinforces the role of brothers. This book introduces readers to Gawain's younger brother, Gareth. ${ }^{15}$ In this tale, Malory uses a motif which most often features the discovery of a father-son bond, but clearly shifts the dynamic to focus instead on the discovery, and notably the concealment, of a bond of fraternity. Additionally, of all instances of terms related to brotherhood present within the Morte, over eighty appear in "Sir Gareth of Orkney" alone. Readers are unable to escape or to

\footnotetext{
15 "Sir Gareth of Orkney" is one section of Malory for which there is no evidence or indication of his sources. While many prominent scholars continue to assert that Malory is working from a lost, unknown source, refusing to attribute the material to Malory's originally, I argue that there is no reason why we should assume there is a lost source and believe, instead, that it is entirely possible for Malory to have created the Gareth story. For discussions of Malory's originality or lack thereof, see P. J. C. Field, "The Source of Malory's 'Tale of Sir Gareth'," in Malory: Texts and Sources (Cambridge: D. S. Brewer, 1998): 246-60; Wilfred L. Guerin, “The Tale of Gareth': The Chivalric Flowering," In Malory's Originality: A Critical Study of Le Morte Darthur, ed. R. M. Lumiansky, 99-117 (Baltimore: John Hopkins Press, 1964); Ralph Norris, "Another Source for Malory's 'Tale of Sir Gareth'," Arthurian Literature 32 (2015): 59-74; and Ralph Norris, Malory's Library: The Sources of the Morte Darthur, 82-89 (Cambridge: D. S. Brewer, 2008).
} 
forget about the significance of brothers within this section, as they cannot read far before encountering one of the terms for brother or brethren. Note that this section of Malory's text spans only thirty-five (of almost five hundred) folios in the Winchester manuscript, meaning there are more than two uses of the term per folio. ${ }^{16}$ While the terms are not so neatly spaced out as to appear evenly across all folios, the effect is such that readers continually encounter the terms before the story progresses too far. This is a perfect example of how Malory clusters fraternal terms around key moments in the text when characters are doing their best to overcome the potentially problematic aspects of fraternity.

The abundance of fraternal terms within this tale is especially noteworthy because it is within this section that Malory deliberately depicts the attempts of a character to distance himself from his own consanguine brothers, and to forge his own sense of community. Appearing at court as an unknown, and refusing to give his name, Gareth attempts to break free from the constraints of brotherhood (224.26). ${ }^{17}$ Gareth's attempts to distance himself from his family, but more specifically from his brothers, are startling to the reader, as not only do brothers appear consistently throughout the tale, but the Orkney brothers, in particular, feature constantly as brothers both within this tale and within the Morte as a whole. Throughout the Morte, fraternal terms apply to the Orkney brothers well over one hundred times, meaning that roughly a quarter of the references to

\footnotetext{
${ }^{16}$ Note that the Winchester manuscript (London, British Library, Additional 59678) is incomplete, as both the first and last quire are missing.

17 This deliberate separation of Gareth from his family has been noted by Carolyne Larrington, who points out that "Gareth is anxious to conceal, even to escape, his lineage; he wishes to forge his own identity through his career as Bewmaynes, posing as a bel inconnu, though he knows his kin group all too well". Carolyn Larrington, "Sibling Relations in Malory's Morte Darthur," Arthurian Literature 27 (2011): 64.
} 
brothers or brethren within Malory's tale are directly related to this one set of brothers. In light of this, Gareth's desire to withdraw from his brothers is all the more startling for readers because the sons of Lot are so often identified as brothers and, in particular, as the brothers of Gawain. As Gawain is not only the eldest brother, but also the one most wellknown from the Arthurian tradition, he is the figure who appears most often throughout the text and is frequently associated with his family. As Bonnie Wheeler points out, "[f]rom Sir Gawain's early moments at court, the text insistently bonds him to his family; he is prominent even in apposition, for his relatives are most commonly identified by their relation to him." ${ }^{18}$ Gawain's blood relationships are consistently presented throughout the entirety of the tale, linking the knight unequivocally to his family. Gawain's adherence to family loyalties, then, is one of the most consistent aspects of his character within Malory's text. Thus, Gareth's effort to remove himself from immediate association with his brothers, though ultimately unsuccessful, is an attempt to free himself from an inescapable set of social expectations which he understands to be both problematic and potentially dangerous.

Gareth's attempt to remove himself from fraternal obligations does not begin as an outward rejection of the sibling bond, but rather as an attempt to establish his reputation based on his own prowess and not the reputation of his older, well-known brothers. Throughout the tale, Gareth's desire to distance himself from Gawain and the others becomes more evident and more vehement. It begins when Gareth requests that Lancelot, not Gawain, knight him (227.10-14), signaling for the readers that Gareth's

\footnotetext{
${ }^{18}$ Bonnie Wheeler, "Romance and Parataxis and Malory: The Case of Sir Gawain's Reputation," Arthurian Literature 12 (1993): 119.
} 
allegiance may well lean towards Lancelot rather than his own kin. He does not look up to Gawain and Gawain's reputation as the pinnacle of knighthood, but to Lancelot. Gareth's distance from his brothers is further highlighted when Gareth encounters Lancelot in a tournament, but "no stroke wolde he smyte Sir Launcelot" (275.27-28). Contrasting this scene, immediately after encountering Lancelot, Gareth meets "with his brothir Sir Gawayne, and there he put hym to the wors, for he put of his helme" (275.3233). Gareth refuses to strike Lancelot, signaling his loyalty to the man who is not his blood relation. But he is more than happy, it seems, to strike his brother, Gawain, though there has been no indication thus far of Gareth's outright rejection of him. Until this point, Gareth desires to gain honour through his actions, not his blood, and he looks up to Lancelot as a paradigm of knightly conduct. This shifts by the end of the book, however, when readers are informed that: "For evir aftir Sir Gareth had aspyed Sir Gawaynes conducions, he wythdrewe hymself fro his brothir Sir Gawaynes felyshyp, for he was evir vengeable, and where he hated he wolde be avenged with murther, and that hated sir Gareth.” (285.29-32). This is the first statement in which Gareth explicitly rejects the fraternal bonds which should tie him to Gawain and the others. This rejection is reemphasized when in "Sir Tristram de Lyones: The Second Book," Gareth repeats his assertion:

"for well I undirstonde the vengeaunce of my brethirne, Sir Gawayne, Sir Aggravayne, Sir Gaherys, and Sir Mordred. But as for me," seyde Sir Gareth, "I meddyll nat of theire maters, and therefore there is none of them that lovyth me. And for cause that I undirstonde they be murtherars of good knyghtes I lefte there company.” (553.28-33) 
What began as an attempt to make a name for himself beyond his bloodline turns into an outright rejection of his association with Gawain and his other brothers. By the end of "Sir Gareth of Orkney," it appears that Gareth has overcome the obligations and demands of fraternity which permeate the text to forge his own path and his own reputation.

While this separation is only temporary and will end tragically in the final book of the Morte, the Gareth section presents readers with a glimmer of what is possible when fraternal loyalty is rethought because, in this instance, adherence to that bond is both excessive and problematic. Malory presents a character who attempts to forsake fraternal obligations not because of jealousy and anger between brothers, but because of the jealousy and anger those brothers exhibit towards others. In complete opposition to Eteocle's disavowing of any loyalty towards Polymyte, Gareth's refusal to maintain his bond with his brothers is presented as an example of his upstanding moral character. Whereas Lydgate explored how Eteocles's denial of any obligations to Polymyte reflected his poor governance, both of himself and of Thebes, Malory here highlights the fact that good men can, and often were, prevented from practicing good governance because of their unwavering and unquestioning loyalty to brothers, even when the actions and behaviours of said brothers caused more harm than good. Gareth, in this tale, attempts to overcome blind obedience to fraternity when that fraternity is dangerous for both the self and the polity. Malory demonstrates that the desire for vengeance, not only against a brother but also in honour of a brother, is problematic and Gareth, displaying his ability to self-govern his own behaviour and emotions, refuses to participate in the vengeance which fraternal loyalty would otherwise demand. 
The importance of fraternity in "Sir Gareth of Orkney" is not limited to exploring Gareth's inability to fully distance himself from the ties of fraternity that permeate the Arthurian world. Brothers in this section also play an important role in the establishment of Gareth's own position of power and governance. Just as Gareth cannot escape his connection to Gawain, he also cannot escape other fraternities during the quest he undertakes when Lynette appears in Camelot, seeking the help of a knight. As previously stated, Malory makes use of the "Fair Unknown" trope of having the disconnected protagonist encounter adversaries who are strongly bonded through their fraternal relationship to one another. Rather than encountering two sets of brothers, as seen in Lybeaus Desconus, Gareth fights individual battles with a series of brothers, each of whom initially harbours a grudge against him for his treatment of the previous brothers. Of these brothers, Gareth's first encounter is with the Black Knight, whom Gareth kills in combat (233.30-234.2). Gareth takes the black amour and dresses himself before continuing his adventure (234.3-4). When Gareth and Lynette continue on their way, they meet with the Green Knight, who immediately recognizes the black armour. Lynette informs him that this is not his brother who travels with her: "Nay, nay," she seyde, "this unhappy kychyn knave hath slayne thy brothir thorow unhappynes" (234.24-5). She is annoyed that she has been accompanied by a kitchen boy instead of a Round Table knight. Lynette, wishing to be rid of Gareth, relies upon social conventions which dictate that the Green Knight will be honour bound to avenge the death of his brother. Lynette knows that they are operating within a society in which fraternity is expected to be valued, and she appears to hope that the bonds of blood are strong enough to overpower any other codes. Fraternal loyalty, which was presented as good and necessary in the 
Prose Merlin, is here manipulated to encourage excessive chivalric action. Lynette's hope for the Green Knight to seek immediate vengeance upon Gareth suggests that in her understanding of society, the demands of fraternity outweigh any other social expectations. This suggests a world in which "[f]amilial blood ties represent the excesses of affinity based on blood, or at least the dangers occasioned by such an affinity if pressed to an extreme." ${ }^{19}$ When characters cannot escape fraternity, they are also at risk of being forced into actions to uphold the excessive and rigid demands of that fraternity. If loyalty to a brother is upheld over any other social obligation, it is entirely possible that such loyalties can be manipulated, as Lynette here does, and as is done by Johan in Gamelyn, as we will explore in the next chapter. In the case of Johan, he manipulates his brother for his own benefit, which, as will be explored, is an example of poor self and familial governance. Lynette's willingness and ability to manipulate fraternal bonds when she herself is outside of the relationship demonstrates Malory's anxiety about the way in which excessive fraternity can be used against brothers, to the detriment not only of the individual men but potentially the larger polity. If fraternal obligations are unwavering, they can be used to force men to perform actions which potentially go against their own moral code, and which can have overwhelming costs for others around them.

Malory exposes the potentially dangerous use of fraternal loyalty to further personal grievances. If brothers are bound to avenge slights to one another, no matter what the cost to the polity or people around them, then fraternal loyalty becomes not a force for good, but a force which perpetrates ever escalating violence. Reflecting the

\footnotetext{
${ }^{19}$ Catherine La Farge, "Blood and Love in Malory's Morte Darthur," In A Companion to Medieval English Literature and Culture c. 1350-1500, ed. Peter Brown (Oxford: John Wiley \& Sons, Incorporated, 2007), 242.
} 
excessive and inescapable nature of Malory's fraternity, Lynette's plan initially works, as the Green Knight adheres to social conventions and is suitably dismayed by the news of the death of his brother. Following accepted, and, in fact, expected codes of behaviour, he immediately challenges Gareth: "thou shalt dye for sleynge of my brothir! He was a full noble knyght, and his name was Sir Perarde" (234.29-30). Gareth defends himself, claiming that he has slain Perarde "knyghtly and nat shamfully" (234.32). Gareth eventually wins this fight but refuses to grant mercy unless Lynette asks him to do so. In response to the threat of losing his life, the Green Knight begs: "save my lyfe and I woll forgyff the deth of my brothir" (235.35-236.1). Gareth's ability to overcome the Green Knight convinces him to see past the blood feud which would demand he seek revenge on his brother's killer. The Green Knight forgives Gareth and allies with him, overcoming in this moment fraternal demands for excessive violence in response to the death of a brother. Though Gareth is able to overcome the socially expected adherence to even problematic fraternal loyalty, the potential for such loyalty to be manipulated is still imagined and explored by Malory in this section. The forgiveness that occurs between Gareth and the Green Knight demonstrates a hopeful alternative to the norm, but as the rest of the Morte demonstrates, it is not one which is easy to maintain.

Gareth's first successful attempt to overcome the bonds of fraternity does not last long, as Lynette once again resorts to manipulating fraternal bonds for her own benefit, meaning that Gareth must start all over again in helping another character overcome the obligations society has suggested are owed to a brother and his honour. The narrative has Gareth encounter the third brother of these first two knights, identified as the Red Knight. Again, Gareth is unable to escape the consequences of fraternity for long, and, again, 
Lynette attempts to use the constraints and demands of such relationships to her advantage. She informs the Red Knight of Gareth's adventures with his two brothers: "this knave hathe slayne your brothir, and Sir Kay named hym Bewmaynes; and this horse and this harneyse was thy brothirs, the Blak Knyght. Also I sawe thy brothir the Grene Knyght overcom of his hondys" (238.18-21). Lynette emphasizes two instances in which Gareth has apparently shamed the Red Knight's family: killing one brother and beating the other in battle. She directly calls upon the Red Knight to adhere to the conventions of fraternity and to take revenge for these slights against his kin. Once again, Gareth wins the fight, and an explicit statement of forgiveness is made by the Red Knight (239.1-5). The feud between Gareth and the Red Knight is officially ended with this declaration, and Lynette is once again forced to continue to travel with Gareth.

After departing from the company of the Red Knight, Gareth meets with a final brother, the Indigo Knight, Sir Persaunte. However, it is only after they fight that he is revealed to be the kin of the previous knights:

"Gramercy," seyde Sir Persaunte, "for now I wote well hit was ye that slew my brothir, the Blak Knyght, at the Blak Thorne. He was a full noble knyght - his name was Sir Perarde. Also, I am sure that ye ar he that wan myne other brothir, the Grene Knyght: his name is Sir Pertholope. Also ye wan my brothir the Rede Knyght, Sir Perymones.” (243.9-14)

Once again, Gareth overcomes his adversary and earns his respect and his homage, as he has done with the previous knights. Gareth's adventures have brought him into both combat and then fellowship with a strongly bonded fraternity, who accept Gareth into their communities. And while Gareth is successful in his battles, the effect of his repeated 
encounters with fraternal characters and terminology is that the reader, just like Gareth, must constantly grapple with issues of consanguine brother bonds. In spite of Gareth's efforts to distance himself from his own fraternity, he operates in a world which is structured around such bonds, making fraternity an inescapable reality. Gareth's attempts to establish himself as a knight without relying upon fraternity offer temporary hope that Arthur's realm can survive the dangers of excessive fraternity, even as that danger is amply demonstrated by these brothers.

Just as seen in the Prose Merlin, this tale explores the connection between fraternal aid in governance. Through Gareth's encounters with the four brethren knights, he gains men who will from that moment on be loyal to him, ready to come to his aid whenever he should ask. Gareth, in this way, becomes a lord and ruler in his own right. Like any ruling lord, he now can call upon these men who will bring their own armies of knights to Gareth in times of need. This is first evident in Gareth's encounter with the second brother, the Green Knight. When the Green Knight is defeated, he begs for mercy and promises Gareth men: "for ever to becom thy man, and thirty knyghtes that hold of me for ever shall do you servyse" (236.1-4); "My lorde Sir Bewmaynes, my body and this thirty knyghtes shall be allway at your somouns, bothe erly and late at your callynge, and whothir that ever ye woll sende us" (237.11-13). Gareth informs them that they must be ready to serve Arthur: "Whan that I call uppon you ye muste yelde you unto Kynge Arthure, and all your knyghtes" (237.14-15). Similar pledges are made when Gareth bests the final two brothers, who both also offer Gareth their loyalty and their men at his disposal: 
"Mercy, noble knyght, sle me nat, and I shall yelde me to the wyth fyffty knyghtes with me that be at my commaundemente, and forgyff the all the dispyte that thou haste done to me, and the deth of my brothir the Blak Knyght, and the wynnyng of my brothir the Grene Knyght.” (239.1-5)

and the Rede Knyght com before Bewmaynes with his thre score knyghtes, and there he profyrd hym his omage and feawté at all tymes, he and his knyghtes, to do hym servyse. (239.21-23)

"And now, syn ye have wonne me, this shall I do for to please you: ye shall have homage and feawté of me and of an hondred knyghtes to be allwayes at your commaundemente, to go and ryde where ye woll commaunde us." (243.14-7)

Through his trials against the brethren group, Gareth gains not only a reputation as a good knight but also a position of governance over a small army of men. Significantly, the brothers, at Gareth's insistence, are not only loyal to him, but also to Arthur. This is evident when all three brothers appear at the next Pentecostal feast:

There cam the Grene Knyght and fyfty knyghtes with hym, and yeldyd them all unto Kynge Arthure. Than there com with Rede Knyghte, his brothir, and yelded hym to Kynge Arthure wyth thre score knyghtes with hym. Also there com the Blew Knyghte, his brothir, with an hondred knyghtes and yelded hem to King Arthure. (263.29-34) 
Gareth, while attempting to free himself from the confines of his own fraternal bonds, encounters another brethren group and enlists that fraternity in Arthur's service and in the protection of the king's realm. Fraternity and governance are intertwined throughout the Morte, and Gareth's story explicitly shows this. Even when attempting to ignore his own brotherly affiliations, Gareth's adventures are filled with and influenced by fraternity, and these fraternal adventures have implications beyond his personal quest for fame and knighthood. Gareth continually demonstrates control over his own emotions and behaviour and is rewarded with the governance of numerous people. Malory's Gareth is an example of what is possible if dangerous adherence to fraternity is overcome. Unfortunately, while Gareth is seemingly successful in his endeavours, by the end of the Morte, the forces of fraternal obligation will prove too strong, and even he will be caught up in the devastation of the fall of the Round Table.

As outlined above, drawing upon the conventions of the "Fair Unknown" tale, Malory's "Sir Gareth of Orkney" presents an unknown protagonist who has no recognized kin support network. He must fight with adversaries whose grievances against the hero are specifically caused by their loyalty to their own kin. Blood loyalty, and the demands it places upon the characters within the Arthurian world, holds great power. It drives the actions of both the characters as well as the plot in the Gareth section, where these bonds are openly challenged. This tale is where Malory explicitly foregrounds the conflict between kin and chosen bonds, a fact often noted within scholarship. Kate McClune suggests "that Malory is preoccupied with blood and that he augments and expands his sources in order to emphasize the potentially dangerous outcomes of 
vulnerability to the demands of blood kinship." ${ }^{20}$ Through repeated references to fraternity and its demands, Malory displays characters who are more than just "vulnerable" to demands of blood, but are, in many instances, ruled by them. The danger lies not in the possibility of kinship demands in and of themselves, but in the dangerous potential outcomes when such demands are inescapable, even potentially perilous to others as well as the entire realm. Lynette's attempts to play upon a brother's desire for vengeance reflect the possibility of these "dangerous outcomes." In the "Gareth" tale, Malory appears to present a knight who can overcome the vulnerabilities created by excessive adherence to blood kinship.

Unfortunately, Gareth's success is fleeting, as in the rest of the Morte blood kinship continues to cause problems within Arthur's kingdom. Mapstone convincingly argues that "Malory is powerfully implying that in the secular world knightly loyalties should be driven by attachment to good chivalric conduct (exemplified by Launcelot) rather than by narrow kin-group loyalty," and that "Malory indicates a set of values that would for him be the most positive way of seeing and being - but which are not sustainable when brought into conjunction with the inexorable pattern of plot and destiny in the remainder of the Morte Darthur." ${ }^{21}$ Malory engages with the possibility of overcoming excessive fraternity when necessary for personal growth or for peace within the realm, but ultimately demonstrates his fear that such a world is not sustainable. He presents the Arthurian world not as a nostalgic perfect past, but as a representation of what might have been possible if interpersonal and familial bonds were overcome for the

\footnotetext{
${ }^{20}$ Kate McClune, "'The Vengeaunce of My Brethirne': Blood Ties in Malory's Morte Darthur," Arthurian Literature 28 (2011): 89.

${ }^{21}$ Sally Mapstone, "Malory and the Scots," Arthurian Literature 28 (2011): 116.
} 
good of the realm. His doubt that such a thing can ever truly be a reality is demonstrated in the failure of the Arthurian world to withstand the demands of kin loyalty which govern the behaviours and motivations of powerful fighting men. The possibility of loyalty through chivalric attributes rather than blood is presented within "Sir Gareth of Orkney," but it is not sustained in the remainder of the narrative. Fraternal bonds, and the excessive emotions which appear to accompany them, prove to be too powerful and too prominent to be fully overcome.

\section{The Orkney Brothers and the Fall of the Kingdom}

The Orkney brothers and the bonds of loyalty between them play a major role in the events which lead to the destruction of Arthur's fellowship and kingdom. The figure of Gawain especially is often presented as deeply connected to his kin. Gawain is consistently associated with fraternity throughout Malory's tale, as well as throughout much of Arthurian literature. This association is evident not only through his own fraternity but also through his first adventure as a knight, as his first encounter after being knighted is one in which he comes upon two brothers arguing. When Gawain asks them the cause of their quarrel, one answers: "We fyght but for a symple mater, for we too be too brethirne and be begotyn of oo man and oo woman" (82.21-3). Not only are these two figures related, but they are full brothers. The narrative specifies the fact that they share both parents. In response, Gawain is dismayed to hear that two brothers are fighting each other. He chastises them for their actions: "Forsoth, thys ys a symple cause," seyde Gawayne, "for uncouth men ye sholde debate withall, and no brothir with brothir" (83.12). Gawain's first act as a knight is to reinforce the importance of honouring consanguine 
fraternity. For Gawain, the bond between consanguine brothers is one that should be honoured and upheld. He argues that two brothers should never be at odds with one another, reflecting his sacred view of his fraternal bonds, which readers observe throughout most of the text. Gawain's speech establishes fraternity, and the loyalty brothers should display to one another, as integral to the values of the kingdom. Malory, in this way, recognizes the narrative norm that upholds the idealization of fraternal loyalty, such as we have seen in the Siege and the Prose Merlin, and presents Gawain as a character who valorizes fraternity. However, through the rest of the Morte, and the eventual fall of Arthur's kingdom, that valorization is problematized as dangerous to the realm when it is represented as an unwavering and unquestioning belief.

Gawain is constantly depicted as being in the company of his brothers and is used as an indicator of their identity even in their absence. Gaheris, for example, is first introduced into the text as Gawain's brother and his squire (81.1-2; 82.16-17). Even when Gaheris is not in Gawain's company, he is recognized through this fraternal relationship. When he is taken prisoner, Lancelot sees him being taken away: "Than was he ware that hit was Sir Gaherys, Gawaynes brother, a Knyght of the Table Rounde" (201.12-13). Once Gaheris's own name and identity are given, he is then recognized first as Gawain's brother and secondly as one of Lancelot's fellow Round Table knights. Lancelot furthers the connection of Gaheris to his brother in two ways. First, he explains to the damsel that he must rescue the other: "I se yondir cometh a knyght faste ibounden that is a felow of myne, and brothir he is unto Sir Gawayne" (201.14-16). Then, after successfully rescuing Gaheris, Lancelot informs him that he did so "in especiall for my lorde Sir Gawayne his sake" who, as he points out, is Gaheris's “owne brothir" (203.30-31). Gaheris is not the 
only Orkney identified within the text through his role as Gawain's brother. The same happens for both Agravaine and Mordred..$^{22}$ These characters are constantly presented to the reader through their fraternal relationship to Gawain. It is not only that Gawain is tied to family, but also that his family is tied to him. These close family ties are pushed to the limits in the final book of the Morte. Unlike other texts studied in this dissertation, the Morte examines the danger of upholding fraternity as the most important social bond. While not condemning fraternity itself, Malory does imagine what is at stake when it supersedes all other loyalties.

Just as in "Sir Gareth of Orkney," fraternal terms feature heavily within "The Morte Arthur," with terms related to fraternity appearing more than fifty times in this last tale. Most significant about this particular number, however, is the fact that forty-two of these terms relate directly to Gawain and his kin. It is the blood bonds of the Orkney brothers which prove to be too strong for any of the figures to overcome, even for the sake of the kingdom. Whereas in "Sir Gareth of Orkney," the protagonist appears to find a way to sever his ties with his brothers to form a community and fellowship of his own design, the end of the Morte proves this was simply a temporary break. Fraternity proves to be a dominant social code in the Arthurian world and one which jeopardizes the unity and peace of the Round Table through its unrelenting demand for priority over all other social ties. Throughout the tale, the dominance of fraternity is frequently exhibited

\footnotetext{
${ }^{22}$ For example, Agravaine is identified in a tournament as Gawain's brother (272.31) and Mordred is listed as being in the fellowship of the Damsel Maledysaunte as "Sir Gawaynes brothir" (364.17-9). Gawain also features as a stand-in for the entire Orkney clan in several instances, with the others going unnamed as his brethren. See for example in the king Mark section of "Sir Tristram de Lyones: The Second Book." In the depiction of a tournament, the Orkney brothers, apart from Gareth, are identified collectively as Gawain's brethren nine times (481.8-483.1).
} 
through the constant appearance of the Orkney brothers. "The Morte Arthur" builds upon this, bringing the demands and consequences of such intense familial bonds to the forefront of the narrative to expose fully how impossible it is to escape fraternity within the Arthurian world and how devastating this inescapability is. Whereas in the Prose Merlin repeated references to brothers demonstrate the necessity of such bonds in the formation of a kingdom, in the Morte, repeated fraternal terms present the demands of loyalty to brothers as unavoidable, even when they are at odds with the survival of the realm.

In this final tale, Gareth's inability to fully escape the bonds of blood he shares with his brothers is explicitly evident. While he has previously forsaken the companionship of his brothers, "The Morte Arthur" begins with Gareth in their company. Even his voice is no longer disconnected from his brothers, or at least not from Gawain and Gaheris. Any comment or decision he makes is with one of these two characters. The first instance of this occurs immediately after Gawain refuses to hear Agravaine's charges against Lancelot: "So God me helpe," seyde Sir Gaherys and Sir Gareth, "we woll nat be knowyn of your dedis." (870.27-871.1) While Gareth is voicing his opposition to the plot to expose Lancelot and Guinevere's adultery, he does so at the same time as his brother Gaheris - they speak as one. Gareth does speak on his own shortly after, but it is only to agree with both Gawain and Gaheris in their refusal to take part in the plotting of Agravaine and Mordred: "Nother I," seyde Sir Gareth, "for I shall never say evyll by that man that made me knyght" (871.33-4). Immediately following this, Gareth's voice is once again subsumed into Gawain's: “Alas!" seyde Sir Gawayne and Sir Gareth, "now ys thys realme holy destroyed and myscheved, and the noble felyshyp of the Rounde Table 
shall be disparbeled" (872.1-3). Gareth has tried, in the past, to distance himself from his brothers, but we see him in agreement here with Gaheris, and more specifically, Gawain. As the narrative draws to its tragic end, Malory depicts Gareth as still tied to his brothers despite all his earlier efforts to forsake their fellowship.

It is noteworthy, of course, that Gareth aligns himself with Gawain and Gaheris in this moment, not Agravaine and Mordred. Gawain, Gaheris, and Gareth all disavow any responsibility to support their brothers in their poor decisions. Once again, Malory hints at the potential for problematic fraternity to be overcome, but in the end, it will not be enough to save Arthur's kingdom, though the brothers here do try. It is no longer only Gareth who attempts to distance himself from the dishonourable actions of his brothers. Gawain and Gaheris also acknowledge the danger in the plot proposed by their other brothers and refuse to partake in the attempt to expose Lancelot and Guinevere. In return, Agravaine and Mordred explicitly state their own intention to separate from their brothers. When Arthur arrives, Gawain, Gaheris, and Gareth refuse to remain and be accomplices in the plot to expose Lancelot. When Arthur questions their departure, Agravaine states:

I shall telle you, for I may kepe hit no lenger. Here ys I and my brothir Sir Mordred brake unto my brothir Sir Gawayne, Sir Gaherys, and to Sir Gareth - for thys ys all, to make hit shorte - we know all that Sir Launcelot holdith youre quene, and hath done longe, and we be your syster sunnes: we may suffir it no lenger. (872.6-11) Agravaine evokes the Orkney brothers' familial loyalty to Arthur even as he distances himself from his brothers who refuse to have any part in informing Arthur of Lancelot's 
actions. He uses the prominence of fraternal loyalty, and his willingness to go against this for the sake of the nephew-uncle bond he shares with Arthur, as a means of manipulating Arthur's reaction to his statement. Agravaine, not so subtly, reminds Arthur of what he is giving up in order to serve his king, presenting himself as someone willing to break with his brothers in order to better serve Arthur. He employs the excessive importance of fraternal loyalty within the Morte for his own benefit, as Lynnette did earlier in the text, and as we will see Johan attempt to do in Gamelyn.

When Agravaine is killed in the attempt to catch Lancelot in the queen's chambers, Gawain continues to maintain his distance from his brothers for the sake of the unity of the kingdom. Despite Gawain's attempts, other characters believe that Gawain will be unable to ignore his fraternal duty to revenge Agravaine's death, assuming that he will be forced to act by declaring vengeance against Lancelot, thereby further dividing Arthur's court. Lancelot is the first to recognize the very real danger inherent in the possibility that Gawain will adhere to the socially expected loyalty to his brothers, and Lancelot fears war will come to him because he has "slayne thys nyght Sir Aggravayne, Sir Gawaynes brothir, and at the leste twelve of hys felowis" (879.19-21). Lancelot believes that the value Gawain places upon brotherhood will overshadow all other bonds they might have shared and lead him into war with his former friend. When Gawain refuses to condemn Lancelot for his actions, Arthur attempts to persuade Gawain to fight against Lancelot based upon the loyalty he should owe to his brothers:

"Why say you so?” seyde Kynge Arthur. "For, pardé, ye have no cause to love hym, for thys nyght last past he slew youre brothir Sir Aggravayne, a full good knyght, and allmoste he had slayne your othir brother, Sir 
Mordred! And also there he slew thirtene noble knyghtes, and also remembir you, Sir Gawayne, he slew too sunnes of youres, Sir Florens and Sir Lovell!" (883.14-19)

Just as Lynette endeavoured to manipulate the actions of the Green and Red Knights by reminding them of their duty to avenge the death of their brother, Arthur here attempts to persuade Gawain to seek vengeance based upon Gawain's propensity to honour fraternal blood ties above all else. Arthur tries to manipulate the model of inescapable fraternity by reminding Gawain that it is his duty to avenge his fallen brother, as well as his sons. Arthur, in this moment, attempts to use the bonds of fraternity to force Gawain into an action which will not only bring further discord to the court, but which also has the potential to bring devastating consequences to Arthur's realm. However, Gawain refuses to declare any sort of vengeance against Lancelot, arguing that he had warned his brothers against their actions, and that he fears a war against Lancelot will be detrimental to Arthur's realm (883.20-29). Gawain, here, attempts to free himself from the demands of fraternity for the good of the whole polity. While social codes of fraternity demand that Gawain take action against Lancelot, Gawain is able to recognize the danger in doing so. Gawain understands that if he blindly adheres to the demands of his fraternal obligations, he risks the entirety of Arthur's kingdom, as it will plunge them into war with Lancelot and his followers. Gawain recognizes the potential danger of his own fraternity to the realm, and in this instance, is attempting to overcome the demands of fraternity that dictate the necessity of escalating violence in the form of a blood feud.

The connection between the Orkney brothers and blood feuds deserves further consideration in scholarship to better elucidate the significance of this connection in 
Malory's text. I am not the first to suggest this, nor to engage with the questions concerning this issue. Mapstone, for example argues that the connection of the Orkney brothers with blood feud is at least partly related to their Scottish heritage, a fact which she argues has been overlooked or undervalued in previous scholarship. She claims that the blood feud is "a fundamental feature of late medieval and early modern Scottish society." 23 This idea reveals yet another connection between fraternity and governance in Malory's text. The inability of the Orkney brothers to forsake the blood feud, an integral part of their political heritage, suggests that Arthur's attempt to unite the two realms, though initially successful, is ultimately doomed to fail. Arthur cannot fully reconcile the polities of these two realms permanently, as the underlying beliefs and practices of each are too varied, not only from one another but also from Arthur's idealized vision for his realm. Familial relationships are fundamentally part of the heritage of many of Arthur's knights, best signified through the Orkney brothers, and while these knights may temporarily put aside familial feuds and obligations for the realm and the fellowship of the Round Table, the peace does not last. Once again, Malory utilizes excessive fraternity, something that appears to be inherent in the very fiber and blood of the characters, to demonstrate that the denial of social expectation, even for the good of the realm, can only ever be temporary.

Fraternal obligation, according to Malory, is not something that one can ever truly ignore or overcome. The model of brotherly obligations and associations presented in the Morte suggests that it is impossible for Gawain, Gaheris, or Gareth to avoid the consequences of their brothers' actions, even though Gawain initially tries to do so.

\footnotetext{
${ }^{23}$ Mapstone, 109. See also McClune, "Vengeaunce."
} 
Arthur forces Gaheris and Gareth to stand guard at Guinevere's execution, though the brothers refuse to be armed, in protest of Arthur's condemnation of Guinevere (884.1015). Gaheris and Gareth are killed when Lancelot mounts a rescue, along with many other knights (885.-11). In contrast to his previous attempt to coerce Gawain into action, here Arthur recognizes the catastrophic consequences that a war with Lancelot will bring. Whereas before Arthur wished to manipulate the power of consanguine loyalty, now he fears it. He demands that the death of Gaheris and Gareth be kept from Gawain: "Now, fayre felowis," seyde the kynge, "I charge you that no man telle Sir Gawayne of the deth of hys too brethirne; for I am sure," seyde the kynge, "whan he hyryth telle that Sir Gareth ys dede, he wyll go nygh oute of hys mynde" ... "the deth of them woll cause the grettist mortall warre that ever was, for I am sure that whan Sir Gawayne knowyth hereoff, that Sir Gareth ys slayne, I shall never have reste of hym tyll I have destroyed Sir Launcelottys kynne and hymselff bothe, other ellis he to destroy me." $(886.14-28)$

Arthur knows that while Gawain has forgiven Lancelot for the death of Agravaine, he will be unable to forgive him for the deaths of Gaheris and Gareth, who were not killed because of their own actions and who were unarmed. Arthur recognizes that if Gawain discovers the death of his brothers, the blood feud which ensues will bring an end to any possibility of reconciliation with Lancelot and his kin. Gawain's fraternal loyalty and love of Gareth and Gaheris will demand their deaths be avenged through even more violence. Not only will Gawain wish Lancelot dead, but Lancelot's kin as well. Arthur fears in this moment that Gawain's adherence to fraternity will have the power to prevent 
any sort of reconciliation with Lancelot. Excessive fraternity has the power, here, to ensure that the realm will never be fully whole again. Arthur's ability to govern the land is diminished in the face of the demands of fraternal vengeance. Whereas Eteocles and Polymyte had to contend with their own fraternal anger towards one another, Arthur is constrained by Gawain's fraternity. Eteocles's own actions and refusal to adhere to his promises lead him into war against Polymyte. Arthur is forced into war because Gawain refuses to ignore his belief in his right to seek vengeance for the deaths of his brothers.

As Arthur predicts, when Gawain learns of the death of Gaheris and Gareth, he is overcome with grief and "he felle downe and sowned, and longe he lay there as he had ben dede" (888.1-2). Upon waking he demands to know who killed Gareth and Gaheris. When he learns it was Lancelot, he immediately vows vengeance, forcing Arthur into the fight through their own blood relationship as uncle and nephew:

"My kynge, my lorde, and myne uncle," seyde Sir Gawayne, "wyte you well, now I shall make you a promyse whych I shall holde be my knyghthode, that frome thys day forewarde I shall never fayle Sir Launcelot untyll that one of us have slayne the othir. And therefore I requyre you, my lorde and kynge, dresse you unto the warres, for wyte you well, I woll be revenged uppon Sir Launcelot; and therefore, as ye woll have my servyse and my love, now haste you thereto and assay youre frendis. For I promise unto God," seyde Sir Gawayne, "for the deth of my brothir Sir Gareth, I shall seke Sir Launcelot thorowoute seven kynges realmys, but I shall sle hym, other ellis he shall sle me.” (888.23-32) 
Gawain immediately recognizes that fraternity demands the deaths of Gareth and Gaheris be avenged. Gawain can no longer consider what his actions, nor the actions he demands of Arthur, might mean for the realm as nothing is more important than the fraternal obligations which he must fulfill.

Gawain's excessive reaction to the news of his brothers' deaths is, however, completely in line with the way in which Malory presents true and deep emotion throughout the whole of the Morte. In her exploration of the affective turn in literary studies, Saunders points out that "Malory, like the romance writers who precede him, makes natural the conventions of behaviour associated with love-sickness and grief, in particular, which play such essential roles in Arthurian history. These emotions, above all, underpin the key moments in the narrative." 24 Saunders also observes that a lack of outward or physical response to emotion is not natural in Malory's text: "Such containment of emotion is negative, indicating lack of true feeling, unnatural assertion of mind over body and conscious deviance from the affect that should underpin virtue." 25 This is evident within the Morte when Arthur, attempting to coerce Gawain into action against Lancelot, chastises Gawain specifically for his lack of emotional response to the death of Agravaine, as outlined above. Arthur criticizes Gawain for containing his emotions and not acting upon the grief he must feel at the loss of his brother. Gawain, in this instance, demonstrates incredible self-control and mindful governance of his emotions, as he refuses to be goaded by Arthur's insistence that he should seek

\footnotetext{
${ }^{24}$ Corrine Saunders, "Writing from the Heart: Malory's Le Morte Darthur," in Emotions in English Arthurian Romance, eds. Frank Brandsma, Carolyne Larrington and Corinne Saunders (Cambridge: D. S. Brewer, 2015), 42.

25 Ibid., 43.
} 
vengeance for the deaths of his brother Agravaine and his sons. In Malory, good selfgovernance is not demonstrated through complete and unwavering adherence to fraternity, but through a character's ability to overcome the bonds of brotherhood when they are both excessive and problematic to the polity at large. It is not Gawain's emotional reaction to the death of his brothers that is the issue, but rather his inability to overcome those emotions when they require actions that put others and the realm at risk. Gawain's emotional response is valid, expected, and, in many ways, a laudable display of his love for his brothers. It is his response to those emotions, and his unwillingness to see fraternal loyalty as anything but all-encompassing, which necessitates immediate retribution when a brother has been killed.

The immediate pledge Gawain makes to avenge the deaths of his brothers, which follows shortly after he has defended Lancelot's rescue of the queen, may at first appear as a sign of what some critics have considered to be Gawain's inconsistent character. ${ }^{26}$ He has, as we have seen, refused to condemn Lancelot for the previous murder of Agravaine. However, as Benson argues, this "speech has been added by Malory to stress that Gawain's reaction does not represent a change in his values, but rather their fatal consistency. ${ }^{27}$ Gawain has always put family ties first. Gawain values and adheres to the bonds of blood throughout the Morte. Benson also claims that "Gawain argues that Lancelot must rescue the queen or die in the attempt in order to preserve his worshyp" as that is exactly what "he himself would do in a similar situation." 28 Just as Launcelot must

\footnotetext{
${ }^{26}$ See Barbara Gray Bartholomew, "The Thematic Function of Malory's Gawain," College English 24 (1963): 262-67. Bartholomew explores criticism surrounding Malory's complicated characterisation of Gawain.

27 Benson, 269.

28 Ibid., 269. Malory, 887.16-8.
} 
rescue the queen, so too must Gawain avenge the death of his brothers. ${ }^{29}$ Gawain is bound by the laws of fraternal loyalty and in order to uphold his honour, he must seek vengeance for the unwarranted murder of his brothers. Whereas before he was able to rationalize his decision to refuse to seek revenge, now he is forced to ignore all other loyalties in favour of the allegiance he owes to consanguine fraternity.

Gawain pursues vengeance against Lancelot at the not only at the cost of his own life, but at the risk of civil war. "The Morte Arthur" questions the ability of any characters to overcome the demands of the bonds of consanguine brothers, or even to manipulate them. The realm is broken apart as characters cannot escape the consequences of strict and excessive adherence to blood, especially in relation to brothers. Gareth and Gaheris suffer death because of their relationship to Mordred and Agravaine, Gawain is forced into the pursuit of vengeance for the death of his brothers, and the entirety of Arthur's court is forever fractured because of the disproportionate value placed upon bonds of brotherhood in a community meant to be bonded together through chivalric honour. Here, as in the Prose, consanguine fraternity is represented as more powerful than chosen brotherhood, but with distinctly different connotations. In the Prose, the power of consanguine fraternity is a force for good and is necessary for the establishment of the realm. In the Morte, the power of consanguine fraternity is dangerous in its excessive and uncontainable nature, making it potentially perilous for the kingdom. Readers of Malory are unable to ignore the power and the danger of consanguine bonds

\footnotetext{
${ }^{29}$ Corrine Saunders identifies yet another tragic aspect of this event, as she points out that "[i]t is Launcelot who prophesies the harm he may do" as he worries that he will bring harm to those he considered close friends. "'Greater Love hath no man': Friendship in Medieval Romance," in Traditions and Innovations in the Study of Medieval English Literature: The Influence of Derek Brewer, eds. C. Brewer and B. Windeatt (Cambridge: Cambridge University Press, 2013), 141; Malory, 880.30-1.
} 
in the Arthurian world, just as the constant use of fraternal terms make it impossible for readers to escape the fact that fraternity is a tragic driving force of the entire narrative. Malory's Le Morte Darthur depicts the ability of excessive kin loyalty to dictate how the land is governed. Fraternity and the obligations associated with it, in Malory, are inescapable both for the brothers who share a bond and for leaders who must work with or against those relationships as best they can. Inescapable fraternity, because of its susceptibility to manipulation and strategic invocation as well as its emotional force, plays a crucial role in the downfall of the Arthurian realm.

\section{Conclusions}

Malory's model of fraternity recognizes the powerful position of brothers within the Arthurian realm. But rather than praise such a bond as a positive exemplum, the text questions the dangers of one relationship being upheld to such a degree, especially when it conflicts with other social obligations and loyalties. Le Morte Darthur questions what happens when fraternity becomes too integral to the kingdom and the structures of power which uphold it and explores the potential consequences for Arthur's realm when brotherhood is expected to be upheld above all else. Fraternity would not have been an entirely neutral concept for contemporary readers in the fifteenth century, as the country's political climate was one of civil wars, with the Wars of the Roses ranging from $1455-85$. It is unlikely that readers, even if they did not make direct connections between the Arthurian battles and those fought by their own brothers, fathers, and cousins, could escape the fact that fraternity, and its demands of loyalty, had its own influence on their contemporary world. The connection between fraternity and its power 
within governing bodies in the period means that Malory's focus on the inescapable demands of fraternity reflects the political atmosphere of the period, and so would have resonated with readers in the fifteenth century. We need only return to the example of King Edward IV from Chapter One. George, Duke of Clarence, participated in rebellions against his own brother, and Edward was forced to grapple with this. While he initially reconciled with George, he eventually had his own brother executed on the charge of treason. Malory himself was a knight who was imprisoned during the ninth year of Edward's reign and would have been directly affected by rebellions in the kingdom at the time. Fraternity appears inescapable in Malory not through divisions between brothers, but through divisions with other social or political groups caused by the demands of fraternal loyalty. As Megan G. Leitch highlights, Malory's text demonstrates a shift in English literature at the time: “[w]hereas earlier verse romances show unity overcoming divisions within families or fellowships, prose romances such as Malory's Morte Darthur... showcase what not to do by focusing on the disastrous results of divisions within affinity groups. ${ }^{\prime 30}$ The Morte demonstrates the destructive power of adherence to kin loyalty. Leitch also emphasizes the fact that:

The composition and survival of these earliest English prose romances coincides with and was informed by the Wars of the Roses and its aftermath. Over the course of a few decades troubled by multiple viable claimants to the throne in the wars between Lancaster and York (1455-

\footnotetext{
${ }^{30}$ Megan G. Leitch, "Malory in Literary Context," in A New Companion to Malory, eds. Megan G. Leitch and Cory Rushton (Cambridge: D. S. Brewer, 2019), 86.
} 
1509), families and neighbours were often divided against each other and old certainties were unsettled. ${ }^{31}$

Leitch identifies that there was a noticeable shift in the literature at the time which reflected the real-world divisions the people of fifteenth-century England were facing. Malory's depiction of Gawain's inability to overcome his loyalty to Gareth and Gaheris, even for the greater good of the community, is one such example of this shift.

Fraternal loyalty in Malory is an inescapable force that has the potential to undermine even the strongest of political foundations. Malory does, indeed, warn against the dangers of division within affinity groups; he also, significantly, warns of the dangers of excessive unity. When fraternal bonds are unyielding and unwavering, loyalty to those ties is just as problematic as divisions amongst them. Unlike the other texts examined in this dissertation, which uphold fraternity as an ideal social bond, Malory questions the implications and potential repercussions of allowing one interpersonal bond to overshadow and overrule all others. The inherent conflict in fraternity is not to blame for this danger, according to Malory, but rather the over-valorization of the bond without thought or consideration about whether it should always be upheld so steadfastly. Brotherhood, like any other social or interpersonal relationship, can become a negative influence over personal behaviour and emotions. Malory explores the consequences for the polity when those in power are bonded by such unwavering codes of fraternal loyalty. From the accidental fratricides of Balin and Balan to Gawain's grief-stricken vow of vengeance against Lancelot, fraternity, rather than being a potential tool for self-

\footnotetext{
31 Ibid., 94.
} 
improvement, as in the Siege of Thebes, proves an inescapable, destructive force in Le Morte Darthur. 


\section{Chapter Five: The Tale of Gamelyn: The Rise of the Gentry}

The process of inheritance, as seen in both legal wills of the fifteenth century and within The Tale of Gamelyn, demonstrates the inherently paradoxical relationship of fraternity. A brother can either be one's closest ally, as in the Prose Merlin, or one's main rival, as was the case with Cain and Abel and Eteocles and Polymyte. When it comes to inheritance, brothers are, by nature, in competition for the same resources from their parents. In the fifteenth century, England appeared to prefer the practice of primogeniture, meaning the eldest son was considered the main heir to his father's lands and money. This process meant that younger sons stood to inherit either less, or nothing at all, when compared to their older brothers, particularly the firstborn sons. This necessarily puts brothers into competition with one another not only for the land, but also for the affection of their parents. The presence of fraternity becomes an obstacle to securing one's future rather than a source of security — not only for princes seeking to gain the throne, but also for the gentry class, for whom being born into wealthy families and positions of privilege did not guarantee their permanent social standing. Younger brothers who stood to inherit less from their fathers were at particular risk of losing their positions of power if they did not obtain their own lands and wealth. In this chapter, I explore the conflict between fraternity and inheritance, and demonstrate how brothers could manipulate, or even deny one another in their attempts to gain or maintain their positions in society. I trace the potentially fraught relationship of brothers and their positions of authority, arguing that in late medieval England, fraternity could be the main obstacle faced when attempting to maintain or gain social and political power. I also 
explore the governance of brothers over one another, and how such positions of fraternal authority could be manipulated and abused, especially when related to the issues of social and political inheritance outlined above.

In this chapter, I examine the romance of Gamelyn as well as wills and correspondence which demonstrate fifteenth-century parental anxieties about the ability of younger sons to uphold their social standing. The authors of these documents all indicate concern for the potential for fraternal feuding or indifference to the plight of brothers. In their wills and letters, parents display doubt about whether their male heirs will be inclined to look after their brothers by allotting them their own share of the land and possessions. While these anxieties are implicit in the wills, they prove to be full founded and legitimate concerns in the tale of Gamelyn, as we witness the refusal of an elder brother to properly care for a younger brother over whom he is granted guardianship. Gamelyn's father states he does not trust the brothers to look after one another, and his doubt is realized when Gamelyn's eldest brother, Johan, takes advantage of his power over the child Gamelyn and Gamelyn's lands, abusing his position of governance as head of the household after his father's death. Under laws of primogeniture, special care had to be taken to ensure younger sons were not overlooked or disadvantaged after the deaths of their fathers, and brothers, seemingly, could not be trusted to instinctively, or even willingly, ensure that their younger brothers were able to maintain the same social positions into which they had been born.

I also continue my examination of the utilization of terms of fraternity by analyzing how in Gamelyn, fraternal terms of address are pushed to their limits and manipulated and abused to maintain corrupt positions of power. The chapter furthers my 
discussion of the conventions of fraternal forms of address by demonstrating how characters can utilize them to manipulate and influence others into particular actions or behaviours. I examine the usage of such terms in the Cely letters, a collection of letters which put the dynamics of three brothers from a fifteenth-century merchant family on display. These letters demonstrate how the convention of fraternal terms can be deployed to remind brothers of their obligation to fraternity and to attempt to garner favours or aid. Both Gamelyn and the Cely letters demonstrate how fraternity is upheld as an important bond and how that very importance can be wielded, for good or bad, to influence other characters. Characters in positions of governance over their family, business, or lands, can use or abuse the obligations associated with fraternity to determine how much power their brothers can hold. As seen in Lydgate, when Eteocles refuses to acknowledge Polymyte's claim to the throne, brothers can actively waver in their acknowledgments of fraternity to either deny a brother his rightful social class and position of authority, or to affirm his high social standing and offer the opportunity to improve it. Fraternal terms of address, in instances when they are accepted, rejected or denied, become a method through which to maintain, claim, or refuse social and political status. Acknowledging or accepting a fraternal relationship is one way to claim membership within a social class, whereas rejecting or severing a fraternal bond can be used to prevent or deny a brother's, often rightful, position of authority. The choice between fraternal rivalry and alliance is always present, and like Lydgate and Malory, the author of Gamelyn grapples with that double-edged sword. 


\section{Inheritance in Wills and Letters}

In the fifteenth century, numerous wills highlight both the practice of primogeniture as well as familial concern for the ability of younger sons to maintain their social class. Written legal and personal documents, on the rise in the late medieval period, were used by parents, particularly fathers, to ensure that their lands and goods would be distributed exactly as they wished after their deaths and could potentially be utilized to circumvent laws such as primogeniture which would leave younger sons at a disadvantage. ${ }^{1}$ Such documents demonstrate trends in late-medieval inheritance. As Kate Kelsey Staples notes in her exploration of the Husting Wills, "a son without brothers inherited $2 \%$ more often than a son with brothers (87\% to $85 \%) . " 2$ Staples highlights the fact that "the number of sons and daughters who inherited real property began to recover around 1400" after such instances had seen a decrease after the plague. ${ }^{3}$ As Staples documents, a "slight preference for single heirs may have been due to recovery from the reoccurrence of the plague in 1399-1400, as testators felt slightly more secure about placing their real estate with one principle heir."4 Whereas in the earlier fourteenth century it appears that testators, namely fathers, spread their lands out amongst their sons more readily, the beginning of the fifteenth century saw a return or rise of primogeniture. This coincides with the production of many of the manuscripts containing the Gamelyn story. In both the courts and the literature of the early fifteenth century, younger sons had

\footnotetext{
${ }^{1}$ For a detailed exploration on the rise of written documents in the later middle ages, see Emily Steiner, Documentary Culture and the Making of Medieval English Literature (Cambridge: Cambridge University Press, 2003).

2 Kate Kelsey Staples, Daughters of London: Inheriting Opportunity in the Late Middle Ages (Boston: Brill, 2011), 98.

${ }^{3}$ Staples, 102.

${ }^{4}$ Staples, 107.
} 
cause to worry about their ability to secure their own lands and future revenue. With the rise of primogeniture practices in the fifteenth century, it is entirely possible that the anxieties within Gamelyn would have resonated with real world issues.

In the wills and contemporary correspondence of the period, fathers and mothers demonstrate concern for the ability of younger sons to maintain their social standing after the deaths of their parents, a concern which, as we will see shortly, is voiced as well by Sir Johan in Gamelyn. In her examination of the Husting Wills, Staples calculates that out of the wills' 8411 recipients, less than $10 \%$ of them were brothers. ${ }^{5}$ Lynne Bowdon examines wills from medieval New Romeny, and points out that "of the 123 wills for the period 1430-1536, only 19 testators (15\%) leave bequests to their own siblings."6 However low these numbers appear, and while Sir Johan fears that no heir can be trusted to look after their brother, there is evidence testators did, indeed, leave land and goods to their brothers. In 1426, for example, John Credy's will includes several items addressed to both his brothers and his nephews:

Also I will pat Richard, my brother, haue half pe Cok and pe garland in Colmanstrete, pe terme of his life, and pe Reuersion to Richard Burdon, skinner, the terme of his life; and after pat, be sold and do for my soule.

Also I will pat Iohn my brother haue my place atte Lee in Deuenshire pe terme of his life; and after be decesse of him, pat Iohn, my godson, his sone, haue pe same place pe terme of his life; and after pe decesse of him,

\footnotetext{
5 Staples, Figure 1.2, 3.

${ }^{6}$ Lynne Bowdon, "Redefining Kinship: Exploring Boundaries of Relatedness in Late Medieval New Romney," Journal of Family History 29, no. 4 (2004): 407-420.
} 
pat William, Adam, my brother sone, haue pe same lond, to him and to his heires males of his body laufully begeton for euermore. ${ }^{7}$

John Credy's will attests to the possibility of leaving land and goods to a brother.

However, in this instance, John Credy's own children have already died and, thus, he could not have left land to them — he opens his will asking to be buried in the same place where his "children be beried." 8 So while an example of a testator bequeathing lands to his own brother, Credy is, in this instance, unable to leave land to his own children. This is not the case in all wills which include land or goods left to brothers, but it does suggest that a major concern for testators was to ensure their lands remained within their own family. The wills also demonstrate the parental concern for younger sons. Just as Sir Johan worries for Gamelyn's future, so do parents in medieval wills worry for the future of their youngest children. ${ }^{9}$ They do not place blind trust in the ability or inclination of eldest sons to look after their younger brothers.

Parental concern for younger sons in matters of inheritance and the maintenance of social standing is also demonstrated in one letter from Agnes Paston, in which she criticizes the behaviour of her eldest son. In this letter, she records a will made by her husband, explaining the way in which he wished to distribute his lands to his younger sons:

\footnotetext{
7 “John Credy, ESQ. of London, Devonshire, etc., 1426," in Fifty Earliest English Wills in the Court of Probate, London. A. D. 1387-1439, ed. Frederick J. Furnivall (London: Oxford University Press, 1964$), 74$. Another example of wills leaving items or land to brothers from this same collection is found in "William Fitz-Harry, of Cosin Lane, London, 1431," 87-89. Fitz-Harry leaves one fourth of his goods to his brother John.

8 Ibid., 73. "Richard Bokeland of All-Hallows the Greater left legacies to his brother," 104-08.

${ }^{9}$ Furnivall's collection includes several examples of wills in which parents specify the lands and goods which are divided amongst their children. See, for example: "Sir WM. Landeford, Knight, 1411," 18-21; "Thos. Walwayn, Esq. of Much Marcle, Herefordshire, 1415," 22-26; and "Roger Flore (of Flower), Esq. of London, and Oakham, Ruthlandshire, 1424-5," 55-64.
} 
And in asmiche as myn husbond, whos soule God assoile, dyuerse tymes and specialy among othere the __ day of the moneth, rehersed to me that the lyvelod whiche he had assigned to his ij youngest, William and Clement, by his will in writing was so littill that they mizt not leve theron wythouzt they shuld hold the plowe be the tayle, and furthermore seying that he had dyuers oder maners, that is to say the maner of Sporle, Sweynsthorp, and Bekham, which maner of Bekham he was purposed to change wyth the maner of Pagrave, and if he my3t bring it abouzt then xuld on of his ij yongest sones haue the seid maners or Sporle and Behkam and no more, and the other yongest sone xuld haue al the remenaunt

And after that the day of next folowing my seid husbond, lying seke in his bed, in the presens of John Paston, his sone and myn, John Bakton, John Dame, and of me, declared his will towching certain of his children and me, at whiche tyme he assigned to the seid John Paston the maner of Gressham in hond, and the reuercion of suche lyvelode as he zave me after my decesse, askyng hym the question wheder he held hym not content, so seying to him in these termes: 'Sir, and thow do not I doo, for I will no geve so mekyll to on that the remenaunt xal haue to littill to leve on'. ${ }^{10}$

Agnes explicitly recalls that her husband wished to ensure that all his sons would be well provided for after his death, so that none of them might have to work the field for a

\footnotetext{
${ }^{10}$ Agnes Paston, 16 September 1466, "Draft Will," 44-45.
} 
living. This concern was also directly addressed by her husband in the presence of their eldest son, John. Agnes is worried that all her sons will not have enough property or goods to be in positions of social power and believes that it is necessary for her children to be in positions of governance over land and people to maintain their current social status. She does not trust that her eldest son will be inclined to look after his brothers and reminds John of his father's wishes to guide him into making the right choices when it comes to his brothers.

Agnes continues to encourage John to look after his brothers so that they all might maintain their current social standing, suggesting that as the eldest, John is, in fact, his brothers' keeper-a role which Cain refuses when first assigned the responsibility. In a letter addressed to John Paston I, Agnes informs him that "Sere John Fastolf hath sold Heylysdon to Boleyn of London, and if it be so it semeth he will selle more" and implores her son to try to acquire some of this land: "Wherefore I preye you, as ye will haue my loue and my blissyng, pat ye will helpe and do youre deuer that sumthyng were purchased for youre ij bretheren." ${ }^{11}$ Agnes believes that Fastolf "wolde be gladere to lete his kensemen han parte than straunge men." ${ }^{12}$ Agnes appeals to her son, asking that he undertake a financial transaction which is not only beneficial to himself, but also specifically to his brothers. She encourages her son to consider both the growth of his own land, wealth, and power and that of his brothers to ensure they are all able to remain within the same social class. John and his brothers must all acquire more land to increase their own positions of authority beyond that bequeathed to them by their father.

${ }^{11}$ Davis, vol. 1, 38.

12 Ibid. 
Another concern relating to inheritance arises when fathers fear their sons, or other beneficiaries, might try to take more than is given to them. Such an anxiety is evident in the Siege of Thebes when Eteocles refuses to give up the crown that he is meant to share equally with Polymyte. This worry is also evident in the 1411 will of Sir W.M. Langeford. Langeford's will provides a detailed list of how his lands and goods are to be divided amongst his children and wife. He does not appear to follow the laws of primogeniture. He leaves his oldest son, Robert, several household items including a bed and mattress, as well as armour, such as a breastplate. He then documents the lands he wishes his younger sons to inherit:

Also y wille pat William myn son haue pe maner of Chale, with all pe purtenaunce beynge in fefyes handes with a-vowson of pe Chyrche in pe Ile of Wyght, to him \& to hys heirs of ys body lawfully be-goton; and yf he deie wythowte heire lawfully of ys body begeton, panne wille y pe forseyd maner with appurtenaunce, remayne to Henre ys broper, and to pe heirs of ys body lawfully goton; and yf pe forseyd Henre deie with-owt issue leful of ys body goton, thane wille y pat be forseyd maner with appurtenauns, remayne to me and myne heirs. Also y will pat Henre my sone have .x. Marcis worth londe zhely to hym and to ys heirs leful of ys body, of pe londes and pe rentes in pe Counte of deuon-schire, beynge in fefees hands, with a-vowsoune of pe chirche of Mounkcocamton; and for defawt of issue comynge of pe forseyd henre, y wille pat yt remayne to william ys broper, and to ys heirs of ys body. ${ }^{13}$

\footnotetext{
${ }^{13}$ Furnivall, 19-20.
} 
Langeford divides lands between his two younger sons, with no mention here of any manors being left to his eldest son. The contents of Sir Langeford's will emphasize that land be given to the two youngest sons in order to provide them with their own positions of governance. Langeford has made certain that he has provided a livelihood for his youngest sons. Also significant in the excerpt is the fact that Langeford has placed very specific limitations on the lands given to William and Henry. The lands are theirs to possess, but they do not have control over who will succeed them as landholders. Langeford has made stipulations that should either son fail to produce legal heirs of his body, then the lands will be returned to his brother, another way in which to ensure his sons and their heirs are able to maintain themselves within their current social classes. ${ }^{14}$ Langeford has seen it as his duty to look after his sons' futures, without allowing one son to take more than his share. The governance of the land, if not passed down to sons, must be passed to their brothers. Langeford's need to ensure that all of his children are not only provided for, but individually protected, is further highlighted by the fact that he stipulates the following condition within his will: "Also my wille ys, pat yf my wyfe or my chyldre askun here resnable [sic] part of my godes aftur cours of law, pan wille y pat pey be excludyd of alle pe avauntage of pe ordinauns of my wylle above y-seyd." ${ }^{15}$ While this in terrorem clause does not directly address the law of primogeniture, it is still a warning to his wife and children that they are expected to accept what is given to them and not seek what they believe they are owed. Such a clause prevents an eldest son from

\footnotetext{
${ }^{14}$ This can also be seen in the will of Thomas Walwayn, ESQ., of Much Marcle, who states that the feoffes given to both his sons, Maclun and William, must only be given to heirs of their bodies otherwise they return to the other brother. See Furnivall, 26.

15 Ibid., 20.
} 
using the laws of primogeniture to claim more of an inheritance than his father has stipulated for him in the will. Langford's will indicates that fathers believed it necessary to provide clear instructions in their wills to protect all of their heirs, and not just the eldest son, a necessity which is foregrounded in Sir Johan's death-bed wishes in the first scene of The Tale of Gamelyn.

\section{Inheritance and the (Ab)use of Fraternal Terms in Gamelyn}

While Gamelyn is thought to have been composed in the mid to late fourteenth century, the majority of the twenty-five manuscripts in which it survives are from the fifteenth century. And while these manuscripts also contain Geoffrey Chaucer's The Canterbury Tales, I argue that the popularity of the Gamelyn poem cannot be attributed solely to its association with the works of Chaucer. ${ }^{16}$ It is imperative that we consider the way in which Gamelyn and the issues raised within it might have spoken to the fifteenthcentury audience reading it, and how such issues might also be a reason why this poem was reproduced so widely in the period. Gamelyn centres upon the relationship between three brothers, Johan, Ote, and Gamelyn, and is particularly focused on the escalating conflict between Johan and Gamelyn. The story begins with their father's deathbed wish that his lands be shared equally among his sons. After their father's death, Johan becomes the child Gamelyn's guardian. Over the years, Johan allows Gamelyn's lands to go to

\footnotetext{
${ }^{16}$ Kenneth Eckert goes so far as to argue that "[a]s important as the matter of Chaucer's (non)connection to Gamelyn is, scholarship has rather obsessed over it to the detriment of examining Gamelyn as a literary work in itself." See Kenneth Eckert, "'He clothed him and fedde him evell': narrative and thematic 'vulnerability' in Gamelyn," Medieval and Early Modern English Studies (Korea) 23, no. 1 (2015): 133.
} 
waste, and when Gamelyn confronts him, Johan manipulates Gamelyn into trusting him once more. Eventually, the feud between the two brothers escalates and Gamelyn must flee into the forest to avoid being arrested at Johan's orders. Johan becomes sheriff and declares Gamelyn an outlaw. Hearing of this, Ote arrives and stands in as surety that Gamelyn will attend the court hearing through which Johan plans to have him executed. Gamelyn, who has made allies of the outlaws of the forest, arrives on the day of his hearing, and together he and his men overthrow the court, sentencing Johan, the judge, and the jurors to their own executions. Throughout the poem, issues of inheritance, social standing, governance, and fraternity are tied together as Gamelyn navigates Johan's treachery while trying to claim his rightful lands and authority as a member of the gentry class. Within the fifteenth century, concerns over inheritance and the ability to maintain one's family's social class suggest that Gamelyn may have spoken to lived preoccupations of those engaging with the romance. As seen through the wills and letters studied above, the importance of having strong positions of governance over land and goods was an ongoing concern for fifteenth-century gentry families. Readers of the Gamelyn story likely would have drawn connections between the brothers' feud and the concerns of their own families.

Though there are several articles which discuss legal issues found within Gamelyn, there has been little focus on the way in which brotherhood is specifically used to challenge or uphold the legal issues found within the poem. Fraternal connections become class connections in this text, and it is through the difficulties Gamelyn faces in obtaining his rightful inheritance that the poem examines the connection between governance and fraternity. In an article exploring medieval law, Emily Steiner states that 
"inheritance raises questions not only about who has the right to claim but also about how kinship and belonging are defined." ${ }^{17}$ While Steiner's focus is on the idea of inheritance and salvation, we see similar issues surrounding inheritance and class in Gamelyn. The conflict between Johan and Gamelyn suggests that inheritance signals belonging not only to a family, but to a particular social class, and the denial of that inheritance, then, is about more than a loss of land or wealth; it is the loss of social identity itself. In Gamelyn, this is explored especially through the issues of wardship, when one brother is placed in a position of authority over a younger brother. In Medieval English Wardship in Romance and Law, Noël James Menuge points out that, at the time of his writing, too little attention had been given to the legal history of wardship within the study of what he terms "wardship romances." ${ }^{18}$ Menuge argues that while Gamelyn "has received much attention from legal historians and literary scholars with an interest in legal matters ... little attention has been given to the wardship matters per se." ${ }^{19}$ Menuge's argument points to a lack of scholarship on the way in which this poem creates social relationships through legally defined responsibilities. Additionally, I argue that while several articles do examine social class within the poem, the way in which Gamelyn implicitly ties fraternal acceptance and denial to class acceptance and denial deserves further consideration. Gamelyn, in his position as Johan's ward, is vulnerable to Johan's

\footnotetext{
${ }^{17}$ Emily Steiner, "William Langland," in The Cambridge Companion to Medieval Law, eds. Candace Barrington and Sebastian Sobecki (Cambridge: Cambridge University Press, 2019), 125.

18 Menuge's list of wardship romances include: Havelok the Dane, Beues of Hamptoun, William of Palerne, and Gamelyn. See Noël James Menuge, Medieval Wardship in Romance and Law (Cambridge: D. S. Brewer, 2001), 6.

19 Ibid., 9, original emphasis.
} 
deceptive and abusive behaviour, as the bonds of loyalty which fraternity demands conflict with Gamelyn's ability to stand up to Johan's manipulation.

Gamelyn is a text which, while not denying the potential existence of good and beneficial fraternity, complicates the possibility of fraternity as an inherently ideal social bond. The poem challenges the potential nobility of fraternity, such as the Prose author and even Lydgate believed in, with the reality that brothers could represent the biggest threat to one another, based upon the fact that brothers are a main source of competition for wealth and property. To mitigate this threat, Sir Johan seeks the advice of wise knights about how to divide his lands amongst his three sons. ${ }^{20}$ At first, he wishes to divide his land equally amongst all three of his sons. The knights attending him are unhappy about this and argue that as the youngest son, Gamelyn does not stand to inherit any of his father's lands. They claim that Johan, as the eldest, should inherit the majority of Sir Johan's lands. If Sir Johan were to follow this advice, Gamelyn's ability to maintain his social class would be greatly reduced in comparison to his brothers, as he would not inherit a position of governance over any land. Attempting to make a concession to Sir Johan's wishes, the advisors do not push for total primogeniture nor do they argue that Johan, as the eldest, should inherit all the land. Instead, they attempt to convince Sir Johan to compromise by dividing his lands in two. They ignore Sir Johan's original concern and believe that Gamelyn's "bretheren mught zeve him lond whan he good cowde" (48). In doing so, the advisors explicitly make Gamelyn's own inheritance dependent upon his brothers' good will. Sir Johan refuses to accept this proposal, as he

\footnotetext{
${ }^{20}$ For the sake of clarity, throughout this chapter I will be referring to Gamelyn's father as Sir Johan and his brother as Johan.
} 
does not believe that Johan will willingly provide for Gamelyn at his own cost. He is fully aware that brothers, while they are perhaps meant to look after one another, are just as likely to see each other as rivals. He then divides his lands as follows:

Iohan, myn eldeste sone schal haue plowes fyue, That was my fadres heritage whil he was on lyue; And my myddeleste sone fyue plowes of lond, That I halp for to gete with my righte hond; And al myn other purchas of londes and leedes, That I byquethe Gamelyn and alle my goode steedes. (57-62)

In the end, Sir Johan leaves the land he himself inherited to Johan as the eldest who, under primogeniture, should be the one to inherit. The lands which he gained through inheritance from his own father are then, through the laws of primogeniture, passed onto his own eldest son. Sir Johan, through his knowledge of the different types of land he owns, demonstrates that he understands how to manipulate or circumvent the aspects of the law which do not align with his own desires for his children. Sir Johan follows traditional inheritance laws by giving Johan the same inheritance his own father gave him. In this way, Johan inherits the right to govern the lands which his father inherited. Gamelyn is given governance of lands which Sir Johan acquired for himself through other means.

While Sir Johan's deathbed instructions are meant to ensure that all three of his sons have the means and ability to maintain and perhaps even improve their own social standing, Gamelyn is immediately at risk of losing any claim to being a member of the gentry class. Gamelyn, who at the time of his father's death is not old enough to govern 
his own lands, becomes a ward of Johan. Johan explicitly has governance not only over Gamelyn's land but also over Gamelyn himself, a position he continually abuses. He manipulates his fraternity with Gamelyn to maintain his position of power over him, and allows Gamelyn's land to go to waste, damaging Gamelyn's future livelihood: “He clothed him and fedde him yuel and eek wrothe, / And leet his londes for-fare and his houses bothe, / His parkes and his woodes and dede nothing wel" (73-5). ${ }^{21}$ Johan has effectively stolen Gamelyn's ability to make a living from the lands, and even if Gamelyn is eventually given governance of those lands, the power he will hold from them has been greatly diminished. When Gamelyn is old enough to recognize the injustice done to him and his inheritance, he challenges Johan. The challenge begins the series of escalating conflicts between the two brothers as Gamelyn fights to retain the social class into which he was born. As Joanna Ludwikoska argues, "what Johan really takes away from Gamelyn is the knightly title, joint to the land, which Gamelyn cannot win back otherwise then by reclaiming his inheritance." 22 Without his lands, Gamelyn is estranged from his ability to maintain himself within the gentry class. Gameyln's situation demonstrates that inheritance issues are very clearly class issues as well.

Johan's manipulation of his authority over Gamelyn is significantly evident in his use of fraternal terms of address. Throughout this dissertation, I have analyzed the frequency of terms such as "brother" or "brethren" in the texts studied. I argue that terms

\footnotetext{
${ }^{21}$ All quotations from Gamelyn refer to the following edition: Skeat, W.W., ed, The Tale of Gamelyn: From the Harleian Ms. No. 7334, Collated with Six Other Mss (Oxford: Clarendon Press, 1884). 22 Joanna Ludwikowska, "(Breaking) The Law: Social Control, Self-Help and Violence in The Tale of Gamelyn," Studia Anglica Posnaniensia 48, no. 4 (2013): 69.
} 
of fraternity are used to reinforce familial bonds and could be used to try and influence the actions of other characters, such as when Gawain attempts to dissuade Agravaine and Mordred from exposing Lancelot's affair with Guinevere. In Gamelyn, fraternal terms of address are a tool for reinforcing familial relationships and for manipulating behaviour. Just as Cain calls Abel brother in Genesis to convince the latter to trust him, Johan uses the term to gain Gamelyn's trust. However, what we see within Gamelyn is that fraternal terms of address can also work to affirm one's position within a particular social class. Both the use of and the response to fraternal address can determine how and if social status is maintained. Both the manipulation of fraternal terms of address and the fact that fraternal relationships become a way of asserting or claiming social status mean that fraternal terms appear frequently with the text. In the poem's 898 lines, such terms appear 82 times. While just over half of those occurrences are narratorial, I focus on the use of the term "brother" as a direct form of address, particularly between Johan and Gamelyn. William M. Reddy's term “emotives” for emotional utterances is useful here to understand how these fraternal terms of address are being utilized by the characters. As Reddy argues, emotives "do things to the world" and "are themselves instruments for directly changing, building, hiding, intensifying emotions." ${ }^{23}$ He also suggests that these emotive terms can be used to influence desired responses:

When one makes an emotional claim in the presence of another, one hears the words, one sees the other's reception of the claim, one feels one's face contracting in suggestive ways. These social and proprioceptive 'inputs'

\footnotetext{
${ }^{23}$ William M. Reddy, The Navigation of Feeling: A Framework for the History of Emotions (Cambridge: Cambridge University Press, 2001), 105.
} 
create or alter activations, often in ways that confirm or enhance the state that is 'described'. Emotives can thus be used as tools for arriving at desired states. ${ }^{24}$

Johan attempts to use such emotional utterances to manipulate Gamelyn by calling him "brother" and, as such, he uses fraternal terms of address as a tool with which to shape Gamelyn's behaviour and responses. Johan never uses the term "brother" when speaking of his siblings to others. While he uses the term a total of nine times throughout the text, each instance is a direct address to either Gamelyn or Ote, and each is used to attempt to influence the emotions or behaviour of the others. ${ }^{25}$ The fact that he does not refer to Gamelyn as his brother when speaking to others highlights the fact that he does not actively view their fraternal connection as significant to him. Johan is a brother in word only, and only when it is beneficial to himself.

Johan is, in fact, the first to use "brother" as a direct address within the poem when he responds to Gamelyn's anger by reminding the younger man of their relationship. Gamelyn has been considering the neglect of his lands, which were in Johan's care until Gamelyn came of age, when Johan appears, asking “is our mete zare?" (90). Unsurprisingly, Gamelyn challenges his brother, telling him to go and prepare the food himself (92). Johan responds to Gamelyn's outburst, calling upon the fraternity shared between them to attempt to govern Gamelyn's behaviour: "How? brother Gamelyn how answerest thou now? / Thou spake neuer such a worde as thou dost now" (93-94). When Johan first speaks to Gamelyn, he asks his question about their meal and

\footnotetext{
24 Ibid., 322.

25 Only one of these nine instances refer to Ote, though this is partly because Ote and Johan only speak to one another once in the course of the poem.
} 
addresses Gamelyn neither by name nor title. However, when Gamelyn, apparently for the first time, dares to question Johan, the latter responds by directly reinforcing the relationship they share. Johan attempts to curb Gamelyn's temper by invoking the fraternal bond which binds them. Johan uses the language of brotherhood to try to shape the interactions between him and Gamelyn and to reform Gamelyn's self-governance back into a model of subservience which has for so long worked well for Johan.

Johan abuses his position as the governor of Gamelyn's lands just as he abuses his position as Gamelyn's guardian. Rather than look after the lands, Johan lets them go to waste. Instead of protecting Gamelyn, Johan sends men forth to "goth and beteth this boy" (111). In response, Gamelyn challenges his brother to approach him himself so they might settle the issue. He calls upon Johan as "brother," bidding him "com a litel ner" (135). Gamelyn recognizes the fraternity that is meant to bind them but, in response to Johan's own behaviour, is angry enough to manipulate the bond to challenge Johan himself. Gamelyn demands that Johan prove he honours the bond of fraternity between them. However, Johan attempts once more to persuade Gamelyn to trust him, as a brother: "Brother, I wil make thy pees I swere by Cristes ore" (139). Johan then explains to Gamelyn that he had another reason for sending the men to beat him: "I ne dide it nought, brother, but for a fondyng, / For to loken if thou were strong and art so ying." (147-8). Johan calls Gamelyn "brother" twice within this short speech. Johan claims to be testing Gamelyn's merit, rather than seeking to have him harmed. Johan claims that he has given Gamelyn a chance to prove that he is ready and worthy of the lands which he had been promised in their father's will. Gamelyn is willing to accept Johan's apology, but asks that his brother give him the lands which his father left him. Johan promises this 
readily, and the two brothers are reconciled, at least in appearance. As the narrator states: "Allas! 3onge Gamelyn, nothing he ne wiste / With which a false tresoun his brother him kiste!" (167-68). Just as Abel senses no treachery from Cain, Gamelyn does not see Johan's dishonesty. Both Gamelyn and Abel trust in the fraternal address as a sign of a positive relationship. The term "brother" is trusted to represent the bond of compassion and love between them as brothers, which both Cain and Johan use to their advantage. Both manipulate the inherent belief in the goodness of fraternity, demonstrating that brotherly love is not inherent in the relationships at all.

Johan successfully manipulates their fraternity to influence Gamelyn's actions. Gamelyn again accuses Johan of allowing his lands to go to waste, and Johan responds by offering to make Gamelyn his heir: "Herkne, brother Gamelyn what I wol zeue the; / For of my body, brother, heir geten have I noon, / I wil make the myn heir I swere by seint Iohan" (364-6). Johan highlights the fact that he has no heir and offers that position to Gamelyn. He is promising, albeit falsely, not only to provide Gamelyn with the lands rightfully owed to him, but also to give Gamelyn his own lands upon his death. Significantly, he reinforces their fraternal bond by again calling Gamelyn "brother" twice within a single speech. Gamelyn is offered a means to maintain his lands and his social class, by accepting the fraternity between himself and Johan. Gamelyn, in the beginning of the narrative, is reliant upon Johan for his ability to remain within the same class as his brothers. Ludwikowska argues that "Johan belongs to the class of knights and Gamelyn does not." As I do, she views the conflict between Johan and Gamelyn as "not exclusively a private in-family rift about inheritance" and as having "a more social 
dimension."26 Johan is not only Gamelyn's guardian, but he is also currently in possession of the lands which would allow Gamelyn to claim his own position within the gentry class. Ludwikowska argues that "[f]or Gamelyn this means that hard as he might try, he will never rise socially as long as Johan owns the plots of land bequeathed to Gamelyn." 27 If Gamelyn outright rejects his fraternity with Johan, he risks rejecting his own social class as well, or at least the tools he needs to maintain that position. Gamelyn must accept his fraternity with Johan to affirm his own social standing.

Despite Johan's words, his actions demonstrate his desire to separate Gamelyn not only from Gamelyn's own lands, but from Johan’s household as well. After Gamelyn departs to participate in a wrestling tournament, Johan orders that the gates to the estate remain closed upon Gamelyn's return (283-6). Johan also manipulates fraternal terms of address when encouraging Gamelyn to participate in the tournament. He calls Gamelyn “goode brother" and offers Gamelyn use of his best horse (179-82). Johan tricks Gamelyn into a false sense of security, as the latter believes that his brother truly wishes him well. Johan seizes the opportunity to estrange Gamelyn from the estate and, consequently, from his own social class. Gamelyn is meant to be locked out of the lands which would mark him as a member of the gentry class. When Gamelyn returns he find the door closed to him and demands that the porter "vndo the yat" (293). When the porter refuses, Gamelyn breaks down the door and then, overcoming the porter, breaks the man's neck (296-302).

\footnotetext{
26 Ludwikowska, 67.

27 Ibid.
} 
Nancy Mason Bradbury highlights the significance of Gamelyn being physically locked out of his home:

The narrative pays close attention to the material mechanisms of exclusion: the porter has gone to the gate and 'lokked it fast' (286-8); when Gamelyn finds it 'shette faste / with a stronge pynne' (290), he 'smote the wikett with his foote/ and breke awaie the pyne' (296). Both the gate and the porter are emblems of restriction, and Gamelyn 'breaks' the latter just as he does the former: he 'girt him in the nek / that the boonbrake' and then slung him by the arm into a well (302-4). ${ }^{28}$

Gamelyn must force his way back into the household, after which he throws a feast for his own friends, using the wine and meat from Johan's supplies. The gate is representative of Johan's attempts to alienate Gamelyn from both the estate and the gentry class. Johan's rule over the household allows him to deny access to food and shelter, a position which he outwardly abuses. Johan's poor governance of his household is demonstrated in the way he treats his own brother. Just as Cain's inability to govern his own emotions leads to his murder of Abel, here Johan's selfish nature and manipulation of a position of power are represented in his actions towards Gamelyn. Meanwhile, Gamelyn re-asserts his class role by casting himself in the role of host of the feast when he has achieved forcible entry. Gamelyn is being denied his social position through Johan's manipulation. He decides to take what he believes to be rightfully his by force.

\footnotetext{
${ }^{28}$ Nancy Mason Bradbury, "Gamelyn," in Heroes and Anti-Heroes, ed. Neil Cartlidge (Cambridge: D. S. Brewer, 2012), 136.
} 
He asserts a position of authority within the household for himself, overstepping and ignoring Johan's power in the process. Gamelyn uses violence to place himself in a power of governance over the house, demanding the privileges that come with such a position. He ultimately rejects any obligation to respect Johan and their fraternity when Johan himself does not honour that bond.

Gamelyn's rebellion and rejection of Johan's authority is short-lived, as Johan once again successfully manipulates Gamelyn using their bond of fraternity. Once Johan approaches Gamelyn to demand his brother cease his actions and relinquish the authority he had just gained, he is able to convince Gamelyn to trust him once again by swearing to make Gamelyn his heir, as previously mentioned (366-8). However, Johan claims that he must bind Gamelyn for having thrown the porter in the well, explaining that he promised his men that he would do so. Johan begs Gamelyn to allow him to tie his hands so that he is not dishonoured by breaking his vow. Gamelyn, trusting in their fraternity, willingly agrees: “"Brother,' sayde Gamelyn, 'al-so mot I the! / Thou schalt not be forsworen for the loue of me."' (379-80). Gamelyn sees it as his brotherly duty to help Johan uphold his own reputation by allowing Johan to fulfill a vow he made, and he believes that accepting Johan's fraternity will also ensure his ability to maintain his social standing in the future. When Johan offers to make Gamelyn his heir, it should be a moment of affirmation of their familial bond. Knowing that this is the expectation associated with such a gesture and knowing that this affirmation is exactly what Gamelyn seeks, Johan uses that expectation to manipulate Gamelyn further. If Gamelyn wishes to be affirmed as Johan's brother, then he should, theoretically, be concerned for Johan's social standing. Gamelyn believes that Johan's offer to make him an heir is an explicit acceptance and 
acknowledgement of the kinship between them. By believing in his brother's integrity, Gamelyn allows himself to be tricked into a position in which he is again vulnerable to Johan. Gamelyn is manipulated into a position in which Johan has governance over him again. Johan immediately abuses that renewed position of governance, an abuse manifest in his ill treatment of his brother.

After being betrayed by Johan once again, Gamelyn flees his brother's household, making his way to the forest to avoid being arrested on Johan's orders. Johan's power of authority increases following Gamelyn's departure, as he becomes sheriff and immediately uses his power to have Gamelyn declared an official outlaw:

The false knight his brother was scherreue and sire,

And leet his brother endite for hate and ire.

Tho were his bonde-men sory and nothing glad,

Whan Gamelyn her lord wolues-heed was cryed and maad. (697-700)

Johan has Gamelyn made "wolues-heed," meaning that, like a wolf, anyone could hunt or kill him and not be charged with a crime. It also means that all of Gamelyn's lands are forfeit, and Johan is able to claim them as his own. Johan utilizes his position of governance as both sheriff and Gamelyn's older brother to ensure that he gains access to Gamelyn's lands, and to attempt to orchestrate Gamelyn's death. Johan's "hate" and "ire" are emphasized, demonstrating his lack of self-governance, which is further manifested in his willingness to have his brother killed as well as his inclination to abuse the position of 
authority he has gained as sheriff. Just like Cain, Johan is ruled by his emotions and allows anger and greed to dictate his actions and behaviour.

In addition to having his brother outlawed, Johan's corrupt fraternal behaviour is evident in his desire to orchestrate Gamelyn's death. The poem emphasizes this fervent desire in two similarly formatted lines: "For he was fast aboute bothe day and other, / For to hyre the quest to hangen his brother" (785-6); “The false knight his brother forzat he nat that, / to huyre the men on the quest to hangen his brother" (800-1). Not only is Johan willing to allow others to kill Gamelyn, but he is also happy to give the orders for Gamelyn to hang. The attempted execution of Gamelyn at Johan's orders brings us back to the issue of fratricide and the abuse of governance, seen in Eteocles's refusal to cede the throne to Polymyte, thereby cheating Polymyte out of his rightful inheritance. Eteocles abuses his authority to maintain power. Johan abuses his authority to try to cheat Gamelyn out of his rightful inheritance. Eteocles, Johan, and Gamelyn are all willing to kill their own brother to maintain or gain a position of governance and authority. Additionally, while not seeking his other brother Ote's death, Johan seems unbothered by the fact that Ote, standing in as surety that Gamelyn will arrive for the trial, will be hanged in Gamelyn's place should Gamelyn not appear. Johan and Ote do not appear to have any real quarrel with one another aside from Johan's treatment of Gamelyn. However, while Johan may not attack Ote himself, he does not show any concern for his other brother's life.

Gamelyn, too, is willing to play a role in the death of his brother through execution. Gamelyn arrives at his trial and quickly takes over the proceedings with the help of his new allies from the forest. After knocking out the original judge, who 
Gamelyn claims is just as corrupt as Johan, he takes over the judge's seat: "Gamelyn sette him doun in the Iutices seet" (855). Johan attempts to manipulate Gamelyn through the evocation of their fraternal bond: "Lord, I crie thee mercy brother art thou myn" (874). But Gamelyn is no longer swayed by Johan's false invocations of fraternity, and orders "the Iustice and the scherreue [Johan] both honged hye" (879) along with the twelve jurors (881-2). Just as King Edward IV justified the execution of his brother George, Duke of Clarence, Gamelyn, appears to have no qualms about sentencing Johan to death, and is willing to abuse his own, newly gained, position of authority to ensure his own self-interests. While Gamelyn is perhaps justified in sentencing Johan to the same fate Johan had sought for him, it is still significant that Gamelyn willingly participates in the death of a brother. Removing Johan as a source not only of prosecution, but also, significantly, of competition allows Gamelyn to secure his own social standing in a way that adhering to Johan's idea of fraternity never would have done.

Neither Gamelyn nor Johan come across as ideal brothers or even as ideal rulers within this poem, as both of their faults and flaws are openly presented within the tale. Both are willing to do whatever it takes to keep or take land and power. Gamelyn's refusal to save Johan from execution is not so different from Johan orchestrating a trial so that Gamelyn might be sentenced to hang. Both brothers exploit their positions of governance for personal gain. Gamelyn benefits directly from having Johan, and those who supported him, tried and hanged, just as Johan had sought to benefit from Gamelyn's execution. Following the sentencing of Johan and his accomplices, Gamelyn's social position is secured as the king makes him "Chef Iustice of al his fre forest" while "sire Ote his brother made him his heir" (893-7). Gamelyn regains the governance over his 
lands which his father gave him, he will inherit Ote's lands after his brother dies, and he obtains even more power through his role as chief justice of the forest. The fact that Gamelyn uses excessive violence to overthrow the authority of the court and still comes out victorious in the end of the narrative is somewhat troubling. This challenges the extent to which we can view Gamelyn as an exemplum of proper conduct. ${ }^{29}$ The actions and behaviours of the protagonist are often morally questionable. However, Gamelyn uses violence to reclaim his own position of authority, and unlike Johan, does not abuse those beneath him. As Maurice Keen suggests, "violence in the Tale of Gamelyn is justified, for the author and his audience, by the fact that it is done in the cause of right in the battle against injustice." ${ }^{30}$ Johan, on the other hand, is presented as a problematic character specifically designed to expose the dangerous potential for men to use and abuse their positions of authority, as well as to manipulate the concept of fraternity to the detriment of those in their care or employ. While Gamelyn's own actions are excessive and still somewhat problematic, he is granted a position of authority because he has proven to be a better governor of people than Johan.

This said, Gamelyn's willingness to manipulate fraternity for his own gain is demonstrated through the fact that he uses fraternal terms of address to his advantage. Gamelyn himself relies upon the fraternal address in order to reinforce his relationship with Johan, and later Ote, and to claim his position within this family — and by extension, the gentry class. While there is no evidence that he is insincere in his claims of fraternity,

\footnotetext{
${ }^{29}$ For others who also engage with the violence in the poem, see Ludwikowska; Richard Kaeuper, "An Historian's Reaching of 'The Tale of Gamelyn'," Medium Aevum 52 (1983): 51-63; and Maurice Keen, "The Tale of Gamelyn," in The Outlaws of Medieval Legend, 107-123 (London and New York: Routledge, 2001). 30 Keen, 90-1.
} 
the fact remains that he does actively use fraternity for his own benefit. Gamelyn, in order to be in a position where he can actively govern the lands given to him by his father, must align himself with his brothers, particularly Johan, who has maintained control over Gamelyn's lands. However, Gamelyn's utilization of fraternal terms is quite different from Johan's. Unlike Johan, Gamelyn uses the term "brother" when referencing his siblings in their absence. He refers to both Johan and Ote as his brothers when speaking with others. ${ }^{31}$ Gamelyn connects himself to these two men, both affirmed in their social positions, to align himself with their social class. Gamelyn understands that one way to claim his own position in the gentry class is to reaffirm and prove his relationship to Johan and Ote.

Gamelyn's understanding of one's ability to maintain or gain social position through the acceptance and establishment of formal bonds like fraternity is evident when he aligns himself with Adam, his brother's steward. When Gamelyn has been betrayed, yet again, by Johan, and tied to a post within the main hall, he appeals to Adam for help, using a similar promise in each instance: "For the mochel loue my fader loued the, / Yf thou may come to the keyes lese me out of bond, / And I wil parte with the of my free lond" (400-2); "Thou schalt fynde my brother atte laste fals; / Thefor, brother Adam louse me out of bond, / And I wil parte with the of my free lond" (408-10). Gamelyn uses the promise of fraternity and land in conjunction, just as Johan has done previously, to encourage Adam to align himself with Gamelyn and to set him free. Gamelyn connects Adam's ability to improve his own social station with the necessity of forming a bond

\footnotetext{
${ }^{31}$ For examples of this see 426 (Johan) and 792 (Ote).
} 
based upon fraternity. As Bowdon also points out, "kinship is the language of legitimation, so that property (in its widest sense) is mediated through discourses of kinship and kinship is mediated through discourses of property." 32 Adam must accept Gamelyn as a chosen brother in order to improve his own social standing. In doing so, Adam, as a brother, would be obligated to help Gamelyn out of his current predicament. Gamelyn creates a bond of fraternity with Adam which then demands that Adam honour their bond by offering Gamelyn his help.

Gamelyn is an attractive "brother" for Adam precisely because he is in, or will be in, a position of higher governance than Adam himself can achieve. Eckert, in his examination of Adam's influence over Gamelyn, views the relationship between the two characters as "paternal," arguing that Adam serves as "a sort of father-figure" who "protects but also fosters Gamelyn." ${ }^{33}$ However, by naming Adam as brother, Gamelyn explicitly creates and invites the possibility of a fraternal relationship between Adam and himself, rather than a paternal one of authority and subservience. Gamelyn, theoretically, offers Adam a bond of equality. He relies upon the belief in fraternity as an ideal model for homo-social bonds, a belief we have seen in the formation of the Round Table in the Prose Merlin. Adam is put into a position in which he must choose whose governance he prefers, Johan's or Gamelyn's. As he points out, he has served under Johan for “this sixtene yeer" (404). However, as stated above, Gamelyn reminds Adam that Johan is false and cannot be trusted. Gamelyn's appeal to Adam as "brother Adam" is directly correlated to the giving of lands. Adam cannot accept the promise of lands without

\footnotetext{
32 Bowdon, 409.

${ }^{33}$ Eckert, 141.
} 
accepting the pseudo-fraternity with which Gamelyn has prefaced the offer. Adam denies the governance of Johan to accept Gamelyn's fraternity and, subsequently, the future governance of his own land. Gamelyn forms a bond of loyalty with Adam not only through the promise of land as a reward, but also through a kinship pact, echoing a discourse which permeated legal understandings of both inheritance and kinship at the time. Even though, thus far, fraternity has been presented as anything but ideal in this romance, Gamelyn is able to manipulate societal expectations of the nobility of fraternity. Though he may plan to uphold his vow, the fact that he willingly uses fraternity to influence Adam's actions suggests that Gamelyn, like Johan, relies upon fraternal obligations to manipulate others into helping him.

Though Gamelyn does, at the end of the poem, gain governance over his own land, the romance does not present Gamelyn as a character who exhibits good selfgovernance and real self-improvement throughout the narrative. Gamelyn and Johan, then, are not opposite characters, with one being wholly good and one being wholly evil. Rather, they are both contrasted with Ote. There are also several ways in which Ote serves a foil for Johan. Whereas Johan is the one who imprisons Gamelyn, Ote is the one who seeks to free his brother: "Anon as sire Ote herde how Gamelyn was a-dight, / He was wonder sory was he no-thing light, / And leet sadle a steede and the way nam" to go immediately to Gamelyn's aid (731-3). Eckert points out that “Ote's sacrificial selflessness represents an opposite morality to that of John." ${ }^{34}$ Ote acts a brother should, whereas Johan has abused Gamelyn's adherence to fraternity. While Johan falsely claims

\footnotetext{
${ }^{34}$ Eckert, 143.
} 
that he will make Gamelyn his heir to gain his brother's loyalty and trust, Ote makes Gamelyn his heir without any apparent benefit to himself (897). Ote performs as a brother should without needing to outwardly identify himself as one verbally. Ote's actions are fraternal even when he does not feel the need to formally address his siblings as "brother," whereas Johan's words speak of fraternity, but his actions fail to represent the bond.

One of the most striking ways in which the Ote and Johan differ is in how they address Gamelyn, and to a lesser extent, each other. Unlike Johan, Ote does not appear to rely on fraternal terms of address to acknowledge his relationship with his brothers. Instead, he behaves in a way that demonstrates his loyalty to them, particularly through his willingness to look after Gamelyn as his younger brother. Ote risks his own life and lands for the sake of Gamelyn but does not need to explain that he does so because they are brothers. Ote, in fact, only uses fraternal terms twice, when he challenges Johan's behaviour and treatment of Gamelyn: "We ben but thre bretheren schul we neuer be mo; / And thou hast y-prisoned the beste of us alle; / Swich another brother yuel mot hym bifalle!" (736-8; emphasis mine). While Ote here does use fraternal terms, they are not utilized as a form of direct address which must be acknowledged and answered. They function as a reminder for Johan of how he should behave in relation to Gamelyn, rather than as an attempt to reinforce Ote's own relationship with Johan. Ote reminds Johan of his position as a brother and of the fact that Johan is not performing that role in a proper or acceptable manner. Ote, at no time, addresses Johan or Gamelyn as "brother," either to influence their behaviour or to reaffirm his relationship to them. He uses "Sire," (735) and Gamelyn's name (839) but never relies upon the term "brother" to influence actions 
of his siblings. Ote's actions prove him to be a true brother; he does not need to call Gamelyn or Johan "brother" to inhabit this role. Ote supports his brother without needing Gamelyn to insist upon the bond shared between them. Even calling Gamelyn "Sire" is an acknowledgement of Gamelyn's rightful place in a powerful social class. Ote recognizes and acknowledges Gamelyn's social position without having to manipulate or rely upon the fraternal relationship between them. They can be brothers without Ote demanding that Gamelyn acknowledge the bond and without demanding some sort of favour in return for having accepted their fraternity.

While Ote does not rely upon fraternal terms of address, Johan continues to do so in relation to Ote. In his response to Ote, Johan once again invokes the term of brother when attempting to dissuade Ote from stepping up to Gamelyn's aid:

"Brother, in swich a forward I take him to the;

And by thi fader soule that the bygat and me,

But if he be redy whan the Iustice sitte,

Thou schalt bere the Iuggement for al thi grete witte." (747-50)

Johan warns Ote that by posting bail for Gamelyn, Ote will take the latter's place should Gamelyn fail to return for sentencing. Significant for my argument, however, is the fact that Johan directly addresses his relationship with Ote twice: once by calling him brother and once by reminding him of their shared parentage. Johan emphasizes that their father "bigate" them both, verbally reinforcing their relationship as brothers. Notably, Johan does not include Gamelyn in this association. Sir Johan, in this instance, is said to be the 
father of Johan and Ote, while Gamelyn is ignored. Johan refuses to acknowledge his fraternity with Gamelyn through this omission.

Johan and Ote's fraternal behaviours directly correspond to their desire to either estrange Gamelyn from their own social class or to help Gamelyn maintain his social standing. Whereas Johan, concerned only for his own welfare, does whatever he can to prevent Gamelyn from acquiring the lands their father left him, Ote actively makes Gamelyn his own heir so that Gamelyn is assured, at Ote's death, of having the means to maintain himself as a member of the gentry class. Gamelyn, with both his own inheritance and this promise of land from Ote, is assured of his social position. Johan's actions, if unchallenged, would have estranged Gamelyn from the gentry class. Ote not only helps Gamelyn to maintain his social position, but also provides future security. In his examination of the wardship romances, Menuge argues that Johan "represents the 'old order' of primogeniture" while "Ote, on the other hand, represents the new order of inheritance which acknowledged that primogeniture was necessary to preserve estates intact while recognising that other children also needed provision." ${ }^{35}$ Johan, representing unconditional primogeniture, displays concern only for himself as the eldest son. Ote accepts primogeniture, as he does not seek to take Johan's lands for himself, nor does he voice any discontent with his own inheritance. However, he also views it as his responsibility, as a brother, to look after Gamelyn in any way that he is able, given the effects of primogeniture. Johan speaks like a brother while Ote acts like one. He steps up once he is aware of Johan's mistreatment of Gamelyn, putting his own life on the line for the sake of his brother. Ote's behaviour justifies the belief Sir Johan's advisors had in

\footnotetext{
${ }^{35}$ Menuge, 59-60.
} 
what brothers would do for one another, but given the general state of disbelief among parents, represented in the historical documents above, it becomes evident that such brotherly love was not necessarily the natural inclination of siblings.

The fraternal relationship between Johan and Gamelyn is one which mimics the concepts of fraternity which were found in the written wills of the period, and which are represented by Cain and Abel and Eteocles and Polymyte. In each case, the brothers, precisely because of their close blood relationship, represent one another's biggest source of rivalry for family resources. These fictive rivalries demonstrate the ongoing anxiety of fifteenth-century authors over the position brothers occupy as opponents for inheritance, rather than as participants in an ideal homo-social relationship. Even in the wills, conflict is a potential problem which parents seek to mitigate before the father's death has even occurred. Menuge emphasizes the fact that while wills may refer to real people, the relationships presented in both romances and legal documents are, nonetheless, fictive representations:

[E]ach characterisation we examine for clues to the discourse in which it appears - ward, guardian, family members - is a persona, a construct, and no more. Romances and legal treaties do not give us 'real' voices; they offer generalised perceptions - approximations - and although some legal cases contain 'real' dialogue, they are similarly constrained by the conventions which have already been outlined. ${ }^{36}$

\footnotetext{
${ }^{36}$ Ibid., 25.
} 
And while we cannot presume that the people or the relationships found within letters and wills are authentic representations, by examining legal documents of the period, we are able, as Michael J. Zell suggests, "to build up a detailed picture of the testator and his family." ${ }^{37}$ However, even when such pictures are based on reality, we must consider them to be at least partly fictive - a representation of how the authors represented a situation in their own words and through their own biases. However, from the wills, we can gain insight into how individuals perceived their own family and the social bonds within them. Wills offer a different view of the late medieval family unit than documents such as pedigrees, as wills can begin to display insight into the family dynamics and personal relationships between family members. Even while using standard forms and legal terminology, the construction of wills and the choices made within them can reveal potential tensions between the testator and his family, as well as give insight into the testator's perception of how he or she can use the law to ensure their family and loved ones are best taken care of after the testator has died.

While I hereunto discussed concerns for the well-being and future prosperity of younger sons, it is also necessary to consider the social well-being of the eldest son. While not excusing Johan's behaviour in Gamelyn, this consideration will provide a clear picture of how inheritance is directly tied to one's social class. Geert van Iestel highlights “the suggestion that Johan's appropriation of Gamelyn's lands may in some part be

\footnotetext{
${ }^{37}$ Michael L. Zell, "Fifteenth- and Sixteenth-Century Wills as Historical Sources," Archives 14, no. 62 (Fall 1979): 68. As Zell points out, "the terms 'will' and 'testament' are often used loosely and synonymously" but "the first refers specifically to that part of that part of the instrument which deals with real property, the second to that part which concerns the testator's money and moveables". See 67 , note 1 . For the sake of clarity, I predominantly use the term "will" when referring to any type of document bequeathing money, land, or valuables.
} 
motivated by his desire to maintain ... knightly status" and that the "proposal to divide the estate between Johan and Ote should perhaps be interpreted as a compromise between the neighbours' "thought" and Sir Johan's wishes, one which historically would have put the two brothers within comfortable reach of the income range associated with knighthood." 38 While morally, it appears to be Johan's and, to a lesser extent, Ote's duty to look after their younger brother and help him maintain his social class, there are practical limitations, such as the amount of land required to be considered gentry. While not excusing Johan's behaviour towards Gamelyn and his abuse of the land he holds in guardianship, it is entirely possible to consider that Sir Johan's division of his lands made it difficult for Johan to maintain his own position within the gentry class. This is one example of the way in which Gamelyn addresses the intersection of inheritance and social class. It is also an example of the way in which legal idealities, such as primogeniture or partible inheritance, do not always reflect the ways in which situations play out in reality. There are practical issues that such theoretical models do not take into consideration.

The romance of Gamelyn exposes the anxieties inherent in the process of inheritance for brothers, demonstrating the difficulty of maintaining a cordial or loving relationship with someone who could potentially be an obstacle to wealth, prosperity, security, and even social class. Whether a father follows the laws of primogeniture or seeks to share his land equally among all his children, there is a risk that those children will struggle to maintain the same social standing as their father. Menuge argues that "by

\footnotetext{
38 Geert van lestel examines likely values of the land assigned to each brother, and the implications such amounts would have on their respective social standings. See Geert van lersel, "The Twenty Ploughs of Sir John: The Tale of Gamelyn and the Implications of Acreage," in People and Texts: Relationships in Medieval Literature, eds. Thea Summerfield and Keith Busby (Amsterdam: Rodopi, 2007), 119-20.
} 
the time that Gamelyn is thought to have been written in the mid- to late fourteenth century, the debate between primogeniture and partible inheritance was again surfacing" but points out that "Gamelyn does not attack primogeniture ... it accepts primogeniture as inevitable, and necessary. It does, however, threaten it, or rather, show us how it is threatened." ${ }^{39}$ Additionally, Menuge argues that:

"the Gamelyn poet is able to point out the dangers inherent in both primogeniture and partible inheritance without openly blaming either system. By portraying the conflict inherent within each through the complicated emotional battles of dysfunctional family relationships, he shows both how individuals can thwart the system, and how the system can overpower and thwart the behaviour of individuals. The poet can blame his characters." ${ }^{40}$

The author of Gamelyn can "blame his characters" who are ruled by anger and jealousy, but at the heart of the issue is the problem with inheritance. While the author does not condemn either system completely, he does, as Menuge points out, identify the inherent problem which arises when inheritance pits brothers against one another for the family resources. In Gamelyn, Johan and Gamelyn may both act selfishly, willing to forsake fraternity for their own gain, but the fact remains that this rivalry is created by the system and society in which they live. These two brothers are responsible for their own actions, and Johan, especially, is condemned for his willingness to manipulate fraternity and his own position of authority, but the author of Gamelyn deliberately reveals that such

\footnotetext{
39 Menuge, 43, 47.

40 Ibid., 38.
} 
duplicitous behaviour is possible because of the systems in which both the characters and the readers of the romance live.

Gamelyn and the wills included above highlight the potential conflicts which can arise when inheritance and fraternity clash. What one brother gains can be viewed as a loss for another. Brothers share a social class, and they each require adequate resources to maintain their social standing; the lack of such resources stands to create conflict, such as that which arises between Eteocles and Polymyte in the Siege of Thebes. When one brother is given all or most of his father's lands or goods, the other brother is at risk of losing his social position. This is true for those who are in positions of power - to maintain one's governance over land and people, one must have land or people to govern. When greed outweighs fraternal love, brothers become rivals for power. Gamelyn and Johan are key examples of this. Johan's governance over Gamelyn allowed him to maintain power over Gamelyn's inheritance, letting it go to ruin. This threatens Gamelyn's ability to maintain his own place in the ruling social classes. Johan manipulates fraternity and his power to both maintain and improve his own social standing, to Gamelyn's detriment. Johan's manipulation is seen in not only his actions but also, significantly, his understanding of how fraternity works - particularly the way in which he can use spoken social cues to his advantage. In addition to issues of inheritance, the author of the romance also significantly engages with the discourse of fraternity, demonstrating how fraternal terms of address can be used and even manipulated to influence, direct, or coerce brothers into emotional and behavioural responses that benefit the speaker. 


\section{Fraternal Addresses in Fifteenth-Century Letters}

The utilization of fraternal terms of address for reinforcing or seeking emotional connections and responses is not only evident in literary texts of the period but is also found in the personal correspondence between brothers as well. While I have outlined here the various ways in which characters in Gamelyn utilize and manipulate fraternal terms of address, I in no way wish to suggest that every use of these terms is done with self-serving intent. Nor does the use of such forms of address always relate to those who govern their own affairs poorly, though we will see an example of this within the letters examined here. Instead, what is evident in the evocation of fraternal terms of address is the significance of the expected emotional connection they create. Tracing the use of fraternal terms in both literary and historical texts grants us better insight into how the people of fifteenth-century England understood fraternity. The use of fraternal discourses by both literary authors and will or letter writers demonstrates the complex nature of fraternity that existed in the period. We may not know exactly how brothers actually felt towards one another, but we can understand how they were expected to feel. When individuals use fraternal language in either speech or letters to create a sense of obligation between themselves and their brothers, they rely upon the words to evoke a sense of emotional connection. Examining specific language use gives us insight into how authors and individuals represent emotional and affective ties between brothers. Anthony Bale suggests that "[1] etters, whether historical or fictional, with their assumptions of intersubjective communication, are a productive place to look at how emotional situations are rendered into written documents in specific circumstances, and can help us explore 
the intersection of affect, feeling, and emotion." ${ }^{41}$ In the fifteenth century, fraternal terms of address appear frequently in personal letters between brothers, signaling the ability of these terms to represent and evoke the emotional connection between brothers as well as expected obligations of fraternal loyalty.

In a letter from Edmond Paston to his brother, John Paston, the opening immediately establishes their relationship: "Ryth worshipfull brothir." ${ }^{2}$ William Paston II also addressed John Paston in such a manner, opening his letter of 16 June 1452: "To myn most reuerent and wurchepful brodur." ${ }^{43}$ These letters also close with an affirmation of their relationship, as both Edmond and William conclude with a variation of "your brother." John uses these fraternal terms as a way to represent the familial bond of love between them. Regardless of whether his use of these terms represents his authentic feelings, it is a signal of the importance of performing the emotional connection and is evidence of the emotional practices of the period, which Bale argues "can only be retrieved through discourse, language, or enactment," meaning that "letters, texts, poems, images, games, and all sort of cultural media become highly valuable in gauging the construction of feeling." ${ }^{44}$ When language becomes formulaic, such as the use of relationship-identifying terms of address, it becomes a tool through which writers, either literary or otherwise, can create particular effects. In the case of fraternal terms of

\footnotetext{
${ }^{41}$ Anthony Bale, “"Afterword: Three Letters” In Medieval Affect, Feeling, and Emotion," eds. Glenn D. Burger and Holly A Crocker (Cambridge: Cambridge University Press, 2019), 204.

42 Edmond Paston, "To John Paston I," 5 July, 147-48.

43 "To John Paston I," 149-50. Several more of William's letters to John open and with similar addresses.

44 Bale, 205.
} 
address, the use of them is a way to immediately remind the reader of the emotional connection between the two brothers in question.

Terms of fraternal address become a shorthand way of demonstrating the depth of the connection between brothers, reminding readers of the obligations associated with such a bond without needing to list them directly. Another example of a collection of familial correspondence, the late fifteenth-century letters of the Cely family, demonstrates the way in which fraternal terms of address were a standard convention of interpersonal communication as a means of strengthening or reaffirming the connection between brothers. ${ }^{45}$ Several of the letters between the Cely brothers open with some variation of the phrase: "ryght welbelouyed brother." 46 Fraternal terms of address are stylistic tools used within personal correspondences. As familiar tropes, these salutations can also be used in order to bring the fraternal relationship between sender and receiver to the forefront, especially when the sender is relying upon the receiver to respond in kind to requests for aid in some fashion or another. Even though they are standard within the literary genre of letter-writing, explicitly fraternal addresses serve to remind others, even subconsciously, of their obligations based upon the relationship. For example, in a letter sent from Richard to George, Richard relies upon and evokes the bond of fraternity between himself and George, directly calling George "brother," using the convention of letter-writing to remind George of the bond between them:

\footnotetext{
45 Fraternal addresses are not, of course, exclusively the only example of a formal form of address. Many letters open with addresses which highlights the nature of the relationship between writer and receiver. What I am arguing here is not for the uniqueness of fraternal addresses as openings to correspondences, but rather for the way in which they adhere to social conventions in reaffirming social relationships. ${ }^{46}$ See, for example, Robert's 13 April 1476 letter to George, 4; George's 27 September 1476 letter to Richard, 4-5; and Richard's 26 March 1478 letter to George. The Cely Letters, 1472-1488, ed. Alison Hanham (London: Oxford University Press., 1975), 17-18.
} 
Ryght trosty syr and brother, I comaunde me to yow, furthermore informynge yow that at the makynge of thys letter howrre father and mother and all howr good frendys wer in goode hellthe, blessyd be God, and so we hope that zee be // Brother George, the cawsee necessary of my wrytynge to yow at thys tyme ys tys: for soth ther ys grette chepynge now at London of ppellys and wollys to Calleswarde, God be ther spede, and I cannatte schepe no fellys before the ffeste of Wyttsontyde, botte sone haufeter I hope to God to doo // I ham note wlly inredyd, for I haue notte mony by me to pay..." 47

Richard reaffirms his connection to George three times in the opening of his letter. First, he addresses George directly as "brother," reproducing standard address practices. $\mathrm{He}$ then reminds George of their relationship by specifying that he speaks of their father and mother when relating news of their good health. Just as Johan reaffirms his fraternity with Ote by invoking their shared paternity, Richard does so as well, though less bluntly or even perhaps deliberately. Finally, Richard repeats the fraternal term of address, calling him "Brother George" immediately before highlighting the fact that he is not financially able to send a shipment to London. As a merchant family, their livelihood would have been dependent upon such transactions. Richard calls upon George, as his brother, at a time when he seeks to maintain the family's social position. While not asking George directly to send money, Richard's repetition of their familial bond suggests that his own financial difficulties will affect George as well.

${ }^{47}$ Hanham, 20. 
I do not suggest that Richard is manipulating their relationship with ill intent in this instance. Rather, his evocation of a fraternal connection appears to be a standard rhetorical tool used in such situations, and such tools, in other instances, can be manipulated to serve the needs of the speaker or writer. Richard himself acknowledges that fraternal relationships can be manipulated when he writes to George concerning the latter lending money to their other brother, Robert:

I haue ressauyd a letter from you wryttyn at Calles the xxvij day of Marche, be the qweche I do well onderstonde the demynyng of owr brother Robard, and of hys neyd, and how zeve lyke to helpe hym more, and ze wryte to me for covnsell. Syr, me thynkys hyt wel done to lene hym now at his neyd, so that ze may stond sewyr. I wndyrstond be your wrytyng that ze be schargyd with an offe. I pray God make yow well qwtye therof, and owzre father wold be sory that he has chargyd hym so sor, or begone on hys byldyng, byt at the trystys of comforte from you, etc. ${ }^{48}$

Richard acknowledges that it was a good deed for George to have helped Robert out in the past. However, he cautions his brother against doing so in the future: "I awyse you to lene hym no mony, ne do no thing with hym byt for record. 3e knowe the onstedfastenes of hym well inow. I cannote thynke how ze schawll stond sewyr of that ze haue lente hym." ${ }^{49}$ Richard fears that Robert will continue to take advantage of George should the latter lend him any more money. Richard warns George not to be persuaded by Robert's

48 Ibid., 44.
49 Ibid. 
appeals to his own fraternity. Richard, while applauding George's generous nature and upholding of fraternal bonds, cautions George to not be manipulated by their brother. Richard fears Robert will manipulate the bond of fraternity, as we have seen Johan do with Gamelyn. Even while upholding fraternity as an ideal socio-familial bond, Richard understands that such a bond can be utilized and twisted for personal gain. Richard believes that Robert will use the convention of fraternal terms of address to attempt to guide or manipulate George's behaviour, to garner sympathy and support by suggesting subtly that if George is a good brother, he will offer aid and money.

Richard's fear appears to have had merit, as Robert Cely does indeed write to George, asking his brother for financial aid due to his own misfortunes:

Ryght reuerentte and worschepfull broder, I hertterlly recomaunde me to yow. Farthermore, plesse yt yow to wette that at the makyng of thys letter howr ffather and mother wer mery and in god hell, blessyd be God, and so we hop that ze be... I ham att London, and haue ben grettely deshessyd allmoste heuer sen yow departtyd fro Alluelay, and moste parrte haue kepte my bedde, for I hafe ben so seke and sore that I goo wyth a staffe. I thank God I ham now daylly amendynde // Item, Brother George, the causse of my wryttynge ys thys, and I pray yow herttelly of yowr good broderhod that ze wyll do so moche for me to see that Wylliam Borwell, mercer, of London, be contentte of ys byll of xiiij li. xv s., and wat mony yow lay howtt for me I wyll conttentte yow herefor. And I had natte haue 
hade pat mony of Wylliam Borwell at that tyme, I had loste all my platte; werfor, good brother, remember me. ${ }^{50}$

Robert expressly uses fraternal terms of address to evoke an emotional response from George. This letter from Robert mimics several of the traits seen in Richard's letter above, as both letters appear to rely upon conventions associated with written letters in the later medieval period in England. Just as we have seen in Robert's letter, Richard's letter reaffirms a familial connection through formal addresses and by highlighting their shared parentage. He speaks of their parents, reaffirming the familial bonds they share. While both George and Robert utilize fraternal terms of address, Robert, in a fashion similar to Johan, utilizes the terms to continually remind George of the obligations he believes the latter owes to him as brother. Robert bases his request for aid especially on George's "good broderhod," calling upon George to help him by appealing to George's commitment to their fraternal bond. In this manner, he evokes a challenge to George's character, as a good man would help a brother in need. Robert manipulates the bond between them to attempt to influence the other's actions, as we have seen Johan do with Gamelyn. Robert, even more so than Richard, reinforces the fraternal relationship between himself and George by reminding George multiple times of their bond as brothers. He addresses George as: "worschepfull broder," "Brother George," and "good brother," within the span of this short letter. Just as Johan has done, Robert uses the term "brother" to reaffirm the fraternal relationship. If George denies Robert's request for money, according to the parameters Robert sets out in the letter, he denies his fraternal duty.

50 lbid., 89. 
Both Robert and Richard are writing to George to inform him of current financial difficulties. These two documents demonstrate formulaic characteristics associated with personal letters, at least within the writings of this merchant family. There are key differences, however, in the two letters. The first two differences are evident in the fact that Robert's appeal to George is both focused on more personal needs and is more forthright in asking for aid. Whereas Richard informs his brother of his lack of finances to fund a shipment to London, he does not outright ask that George send him the money needed to do so. The information is also strictly tied to the family business. In Robert's case, he begins his appeal not with a statement of financial need, but by informing his brother of his recent poor health. Robert writes himself into a vulnerable position, one which would often elicit sympathy. Robert's financial needs are also less vague than Richard's. Robert needs money to pay a bill, but there is no indication that this bill is related directly to the business. While we as readers cannot say with certainty that the bill is not somehow related to a business expense, the lack of specificity on Robert's part certainly makes it a possibility. Additionally, Robert directly asks George for money. George's success as a businessman, and thus his successful governance of the family business, places him in a position of power over his brother, who is not successful in his own endeavours. Robert relies upon George to do what Johan would not - take care of his brother, even if he must manipulate the expectations raised in the name of fraternity to do so.

These examples of fifteenth-century correspondence between brothers echo several anxieties found in the other texts studied in this dissertation. The letters demonstrate a connection between fraternity and governance. In the case of the Celys, the 
brothers must work together to help successfully manage the family business. The governance of family funds must be a mutual endeavour between the brothers operating within business. Consanguine brothers, in this way, are necessary for the success of the family in the same way that consanguine brothers were necessary in the establishment of Arthur's realm in the Prose Merlin. The Cely letters also reveal the importance of fraternal instruction, such as that proffered by Tydeus in the Siege of Thebes. Richard, knowing that Robert will attempt to manipulate George, attempts to instruct his brother in how to manage the relationship. Richard, like Gareth in Le Morte Darthur, recognizes his brother's flaws. Richard is aware of Robert's poor self-governance and refuses to condone or enable it, warning George not to be taken in by Robert's tactics. The fraternal friction in these personal correspondences may be far tamer than Johan's attempts to have Gamelyn hung as an outlaw, or Eteocles stabbing Polymyte when the latter attempts to save his life, but they are evidence of the complex nature of brotherhood and the difficulties brothers face in navigating these relationships. The literature studied in this dissertation takes these difficulties and amplifies them, pushing feuds and grievances to extremes to imagine what might be at stake when fraternity and governance are connected but conflicting.

\section{Conclusions}

My observations of the language of fraternity found within the documents studied above are not meant to argue that we can learn whether or not brothers actually cared for one another from wills or letters, nor do I suggest that fraternal forms of address are always employed for selfish means. Rather, what I argue is that within these letters there 
exists the possibility for fraternal emotions and behaviour to be manipulated based upon societal norms and expectations. The letters demonstrate that brothers rely upon conventions of fraternity, such as an obligation to aid a brother in need, in these correspondences, and the literature of the period engaged with those conventions in a series of unique ways. I argue that in The Tale of Gamelyn, the author complicated these conventions by questioning the reality on which they were based by demonstrating their vulnerability to manipulation, seen through both Johan and Gamelyn. Within the romance, the utilization of fraternal language, and the expectations associated with said language, echo that which was found within legal documents and personal correspondence of the contemporary medieval period. Gamelyn not only challenges the idea that brotherly love and loyalty are fundamentally natural for brothers, but also examines how such feelings can be manipulated specifically because they are expected as part of an inherent fraternal relationship.

Gamelyn addresses the concern that many medieval parents and children alike would have faced when considering the inheritance left to sons. Whether through primogeniture or partible inheritance, there was always the risk that family resources would not be enough to sustain all children, particularly sons, in their ability to maintain the social class into which they were born. Because of this, brothers, wishing to maintain their own social standing and power, could, and seemingly did, view each other as rivals. Through both Gamelyn and Johan, the author of Gamelyn exposes the potential lengths to which men might go in order to maintain their social standing. Neither Gamelyn nor Johan appear as "good" characters, each willing to manipulate and use his position of power to seek his own brother's execution. Johan, especially, manipulates power the 
same way he manipulates fraternal terms of address, often at the same time, and always for the same goal: preventing Gamelyn from taking any power from him, even by conceding that which legitimately belongs to Gamelyn. Johan explicitly connects Gamelyn's ability to maintain his social position to the bond of fraternity between them. Gamelyn, if he wishes to secure his own lands and his own position of governance over them, is continually forced to accept his fraternal relationship with Johan. And though Gamelyn eventually manipulates and overthrows Johan's authority, as well as that of local law officials, in the end, he is reined back into the authority of the kingdom when the king grants him an official position. At the same time, he becomes aligned with fraternity once again, this time through his position as Ote's future heir. In this romance, governance and social class are inextricably tied to fraternity. The Tale of Gamelyn explores the manipulation and abuse of both governance and fraternity, using an extreme example of fraternal feuding and manipulation in order to demonstrate the potential for conflict between brothers who hold positions of power. 


\section{Conclusion: "Vnder a knotte bounde of broperhede"}

The phrase, "vnder a knotte bounde of broperhede," taken from John Lydgate's

Siege of Thebes, perfectly captures the core consideration at the heart of this dissertation. Brotherhood, as a complex, and sometimes paradoxical, relationship, captivated the minds of fifteenth-century authors. Fraternity became a tool through which these authors navigated issues of self and social or political governance. I argue that the intersection between fraternity and governance within fifteenth-century English literature is demonstrated by these authors when they all, in various ways, focus on the prominence and power of fraternity within their texts. Whether a source for good, as in the Prose Merlin, or a source of unavoidable duty, as in Le Morte Darthur, fraternity is continually portrayed as an inherent part of the political, cultural, and social worlds these authors create in their works. My dissertation, in bringing together a variety of genres, including romances, plays, sermons, letters, and wills, reveals that fraternity represented a useful and malleable lens through which numerous authors and writers could explore the issues of personal and political governance.

Through the methodological framework of the history of emotions, much of my analysis is dependent upon close reading and a detailed analysis of the terminology used with the texts studied. Each chapter has focused on a particular framework through which the author wrote. In the first two chapters, I examine how both scriptural and classical foundations of fraternity were represented in the literary imaginary of the fifteenth century. Chapter One explored the fact that in the scriptural foundations of Cain and Abel, fratricide is older than brotherly love. I argued that both sermons and the cycle 
plays relied upon this inherent conflict within the nature of fraternity to criticize or warn their audiences against being ruled by emotions such as anger and jealousy. The cycle plays demonstrate Cain's fraternal murder of Abel as a direct result of his own lack of self-governance. Chapter Two, focused on John Lydgate's Siege of Thebes, argued that Lydgate uses the fraternal feud of Polymyte and Eteocles from classical literature to warn about the interconnected nature of self-governance and political governance. This chapter also engaged with the monastic discourse of brotherhood which helped shape Lydgate's depiction of both political and self-governance. Chapter Three explored the Rise of Arthur in the Prose Merlin and Henry Lovelich's Merlin, and how these authors understood and depicted fraternity as essential and necessary in Arthur's rise to power. Chapter Four explored the fall of Arthur in Malory's Le Morte Darthur and how, in this text, unwavering loyalty to fraternity comes at a cost to the unity and peace of the realm. Chapter Five concluded my study by exploring fraternity and the rise of the gentry class. In this chapter, I demonstrated how fraternal terms of address could be used and manipulated to obtain, maintain, or even deny social class. The abuse of fraternity and the abuse of authority go hand in hand in this medieval romance, at a time when the contemporary audience would have had to contend with issues of fraternal conflict in instances of inheritance. In each of the texts presented here, I argue that the authors grapple with the double-edged sword of fraternity and explore how characters navigated the complexities of brotherhood, often tying a character's willingness to manipulate, abuse, or even deny fraternal relationships to his unseemly behaviour, poor selfgovernance, and inept and corrupt behaviour in positions of political or societal authority. 
Part of the work I do in this dissertation is to set the literary imaginary of fraternity, in which so many authors present the darkest sides of brotherhood, against the contemporary reality. While fratricide appears in four of the five major texts examined in my dissertation, this cultural imaginary is at odds with the judicial actuary of the lived experiences of men in the fifteenth century. Aside from the pseudo-fratricide of Edward IV's execution order against his brother George, Duke of Clarence, I could find no records of any brother killing another, even accidentally. And yet, extreme fraternal conflict existed as a common anxiety within the writings of fifteenth-century English authors. The potential for fraternal relationships to turn deadly became a useful literary tool for these authors to explore the consequences interpersonal relationships could have for the larger polity. Personal feuds and fighting, when occurring between individuals in authority positions, could have impacts beyond the individuals involved in the original conflict. The literature of late medieval England demonstrates anxiety about the inherent nature of fraternity as one of competition and jealousy. From the scriptural origins of Cain and Abel to the attitudes of brothers when faced with a shared inheritance, brothers were frequently presented as rivals rather than allies. Fraternity becomes a potential source of conflict rather than an assurance of unity.

Through my examination of the various discourses of fraternity evoked in fifteenth-century English literature, I argue that the frequent invocation of brotherhood in non-consanguine social contexts such as the Round Table, guilds, and confraternities, is far more complex and problematic than it first appears. The decision of these organizations to call themselves "fraternities" or "brotherhoods" is founded on the belief that fraternity is a unifying and noble force, and yet the literature of the period 
demonstrates the opposite. Fraternity is not inherently and unwaveringly a force for good. It does not always guarantee social harmony or good treatment of others. Fraternal love and loyalty must be actively chosen. Fifteenth-century English literature continually engages with discourses of fraternity which explore the systematic flaws underlying the invocations of brotherhood, as well as its potential in an ideal, but not often realized, manifestation. Many of the authors studied in this dissertation grapple with the apparently contradictory nature of fraternity, exposing the dangerous potential of fraternity when it is aligned with positions of authority. These authors all, in various ways, question the extent of the influence of fraternity beyond interpersonal relationships. For good or ill, brotherhood and the loyalties associated with it were a powerful force in fifteenth-century England and one which captivated the cultural imaginary of the period. 


\section{Bibliography}

\section{Primary Sources:}

Anselm of Canterbury. S. Anselmi Cantuariensis Archiepiscopi Opera Omnia. 6 vols. Edited by Franciscus S. Schmitt. Edinburg: Nelson, 1946-1961.

---. The Letters of Saint Anselm of Canterbury. 3 vols. Translated by Walter Fröhlich. Kalamazoo: Cistercian Publications, 1990-94.

Beadle, Richard, ed. The York Plays. Vol. 1. EETS, s.s. 23. Oxford: Oxford University Press, 2009.

Benedict. The Rule of Saint Benedict. Edited and translated by Bruce L. Venarde. Cambridge: Harvard University Press, 2011.

Bernard of Clairvaux. St. Bernard's Sermons on the Canticle of Canticles. Translated by A Priest of Mount Melleray. Dublin: Browne and Nolan, 1920.

Biblia Sacra Vulgata (Clementine Version): Translation from Greek and other languages into Latin by Saint Jerome, about 382 A.D. www.drbo.org/lvb/index.htm.

Block, Katherine Salter, ed. Ludus Coventriae; or, the Plaie Called Corpus Christi, Cotton MS Vespasian D VIII. EETS e.s. 120. Oxford: Oxford University Press, 1922; rpt. 1960.

Caesarius of Heisterbach. The Dialogue on Miracles. Translated by H. von E. Scott and C. C. Swinton Bland. London: Routledge, 1929.

Cicero. De Amicitia. In Cicero: De Senectute, De Amicitia, De Divinatione. Translated by William Armistead Falconer, 103-211. Cambridge: Harvard University Press, 1923. 
Davis, Norman, ed. Paston Letters and Papers of the Fifteenth Century. 2 vols. Oxford: Clarendon Press, 1971, 1976.

Dockray, Keith. Three Chronicles of the Reign of Edward IV. Gloucester: Alan Sutton Publishing, 1988.

Ekkehard IV, St Gallener Klostergeschicten, Casus Sancti Galli. Edited and translated by H. F. Haefele. Darmstadt: Wissenschaftliche Buchgesellschaft; 1980

Ferrante, Joan M. and Robert W. Hanning, trans. The Romance of Thebes: Roman de Thèbes. Tempe, AZ: Arizona Centre for Medieval and Renaissance Studies, 2018.

Fowler, J. T., ed. Rites of Durham. Durham: Publication for the Society by Andrews and Co, 1903.

Furnivall, Frederick J., ed. Fifty Earliest English Wills in the Court of Probate, London. A. D. 1387-1439. London: Oxford University Press, 1964.

Gairdner, James, ed. Three Fifteenth-Century Chronicles. London: Center for Metropolitan History, 2007.

The Holy Bible, Containing the Old and New Testaments, with the Apocryphal Books, in the Earliest English Versions, Made from the Latin Vulgate by John Wycliffe and His Followers. Edited by Rev. Josiah Forshall and Sir Frederic Madden. Vol 1. Oxford: Oxford University Press, 1850.

Hanham, Alison, ed. The Cely Letters, 1472-1488. London: Oxford University Press., 1975.

Hudson, Anne, ed. English Wycliffite Sermons Oxford: Clarendon Press, 1983. 
Lacy, Norris J., ed. Lancelot-Grail: The Old French Arthurian Vulgate and Post-Vulgate in Translation. Vol. 2 of The Story of Merlin. Translated by Rupert T. Pickens. Cambridge: D. S. Brewer, 2010.

Lovelich, Henry. Merlin. 3 vols. EETS o.s. 185, e.s. 93, 112. Edited by Ernst A. Kock. London: K. Paul, Trench, Trübner \& Co., 1904-1932.

Lumiansky, R. M. and David Mills. The Chester Mystery Cycle. Vol. 1. EETS, SS 3. Oxford: Oxford University Press, 1974.

Lydgate, John. The Siege of Thebes. Edited by Axel Erdmann and Eilert Ekwall. 2 vols. EETS e.s. 108 and 125. London: Kegan Paul, Trench, Trübner \& Co, 1911 and 1930.

---. “The Testament of Dan John Lydgate.” The Minor Poems of John Lydgate. 2 vols. Vol 1. Edited by Henry Noble MacCracken. EETS 107, 192. 329-62. London; New York: Kegan Paul, Trench, Trübner \& Co., 1922.

Malory, Sir Thomas. The Works of Sir Thomas Malory. Edited by P. J. C. Field. 2 vol., Cambridge: D. S. Brewer, 2013.

Mora-Lebrun, Francine, ed. Le Roman de Thèbes, Lettres Gothiques., Lettres gothiques. Paris: Librairie générale française, 1995.

Morrison, Stephen, ed. A Late Fifteenth-Century Dominical Sermon Cycle. Edited by Stephen Morrison. vol 1, EETS o.s. 337. Oxford: Oxford University Press, 2011. Peter the Venerable. The Letters of Peter the Venerable. Edited by Giles Constable. 2 vols. Cambridge: Harvard University Press, 1967. Harvard Historical Studies, 78. Salisbury, Eve and James Weldon, eds. Lybeaus Desconus. Kalamazoo: Medieval Institute Publications, 2013. TEAMS Middle English Texts Series. 
Skeat, W.W., ed. The Tale of Gamelyn: From the Harleian Ms. No. 7334, Collated with Six Other Mss. Oxford: Clarendon Press, 1884.

Smaragdus of Saint-Mihiel. Commentary on the Rule of Saint Benedict. Translated by

David Barry. Kalamazoo: Cistercian Publications, 2007. Cistercian Studies Series, 212

---. The Crown of Monks (Diadema monachorum). Translated by David Barry. Kalamazoo: Cistercian Publications, 2013. Cistercian Studies Series, 245.

Sommer, H. Oskar. Estoire de Merlin, The Vulgate Version of the Arthurian Romances. 8 vols. Washington: The Carnegie Institution of Washington, 1908-13.

Stevens, Martin and A. C. Cawley, eds. The Towneley Plays. vol 1. EETS, s.s. 14. Oxford: Oxford University Press, 1994.

Wenzel, Siegfried, ed. Latin Sermon Collection from Later Medieval England. Cambridge: Cambridge University Press, 2005.

Wheatley, Henry B., eds. Merlin, or the Early History of Arthur: A Prose Romance. EETS o.s. 10, 21, 36, 112. London: K. Paul, Trench, Trübner \& Co., 1865-98.

\section{$\underline{\text { Secondary Sources: }}$}

Ackerman, Robert W. “Henry Lovelich’s Merlin.” PMLA 67, no. 4 (June 1952): 473-84. Allen, Rosamund S. “The Siege of Thebes: Lydgate's Canterbury Tale.” In Chaucer and Fifteenth-Century Poetry. Edited by Julia Boffey and Janet Cowen, 122-42. London: King's College London, 1991. 
Althoff, Gerd. "Communication at the Abbey of St. Gall." In Understanding Monastic Practices of Oral Communication (Western Europe, Tenth-Thirteenth Centures). Edited by Steven Vanderputten, 11-22. Turnhout: Brepols, 2011. ---. Family, Friends and Followers: Political and Social Bonds in Early Medieval Europe. Translated by Christopher Carroll. Cambridge: Cambridge University Press, 2004.

Ambrisco, Alan S. and Paul Strohm, "Succession and Sovereignty in Lydgate's Prologue to the 'Troy Book'." The Chaucer Review 30, no. 1. (1995): 40-57.

Anderson, David. "Mythography or Historiography? The Interpretation of Theban Myths in Late Medieval Literature." Florilegium 8 (1986): 113-39.

Archibald, Elizabeth. "Malory's Ideal of Fellowship." The Review of English Studies 43, no. 172 (1992): 311-28.

Armstrong, Dorsey. "Malory and Character." In A New Companion to Malory. Edited by Megan G. Leitch and Cory Rushton, 144-63. Cambridge: D. S. Brewer, 2019. Armstrong, Dorsey, and K. Hodges, Mapping Malory: Regional Identities and National Geographies in Le Morte Darthur. New York: Palgrave Macmillan, 2014.

Arnold, John H. and Sean Brady, eds. What is Masculinity? Historical Dynamics from Antiquity to the Contemporary World. London: Palgrave MacMillan, 2011.

Ashley, Kathleen M. "Sponsorship, Reflexivity and Resistance: Cultural Readings of the York Cycle Plays." In The Performance of Middle English Culture. Edited by James J. Paxton, Lawrence M. Clopper, and Sylvia Tomasch, 9-24. Cambridge: D. S. Brewer, 1998. 
---. "Divine Power in Chester Cycle and Late Medieval Thought." In The Chester Mystery Cycle: A Casebook. Edited Kevin J. Harty, 48-68. New York and London: Garland, 1993.

Ayers, Robert W. “Medieval History, Moral Purpose, and the Structure of Lydgate's Siege of Thebes." PMLA 73 (1958): 436-74.

Bailey, Meridee L. "Anxieties with Political and Social Order in Fifteenth-Century England." In Authority, Gender and Emotions in Late Medieval and Early Modern England. Edited by Susan Broomhall, 84-105. Basingstoke: Palgrave Macmillan, 2015.

Bale, Anthony. "Afterword: Three Letters." In Medieval Affect, Feeling, and Emotion." Edited by Glenn D. Burger and Holly A Crocker, 203-17. Cambridge: Cambridge University Press, 2019.

Bank, Stephen, and Michael Kahn. "Intense Sibling Loyalties." In Sibling Relationships: Their Nature and Significance across the Lifespan. Edited by Michael Lamb and Brian Sutton-Smith, 251-67. Hillsdale NJ and London: Psychology Press, 1982. ---. The Sibling Bond. New York: Basic Books, 1982.

Barnie, John. War in Medieval Society: Social Values and the Hundred Years War 133799. London: Weidenfeld and Nicolson, 1974.

Barron, W. R. J. The Arthur of the English: The Arthurian Legend in Medieval Life and Literature. Cardiff: University of Wales Press, 2001.

---. Middle English Romance. London: Longman Press, 1987.

Bartholomew, Barbara Gray. "The Thematic Function of Malory's Gawain." College English 24 (1963): 262-67. 
Baswell, Christopher. "Marvels of Translation and Crisis of Transition in the Romances of Antiquity." In The Cambridge Companion to Medieval Romance. Edited by Roberta Krueger, 29-44. Cambridge: Cambridge University Press, 2000.

---. “England's Antiquities: Middle English Literature and the Classical Past, c. 13501500.” In A Companion to Middle English Literature and Culture, c. 1350- c. 1500. Edited by Peter Brown, 231-46. Maldon, MA: Blackwell, 2007.

Batt, Catherine. Malory's Morte Dathur: Remaking Arthurian Tradition. New York: Palgrave, 2002.

---. "Translation and Society." In A Companion to Medieval English Literature and Culture. Edited by Peter Brown, 123-39. Oxford: Blackwell, 2007.

Battles, Paul and Dominique. "From Thebes to Camelot: Incest, Civil War, and KinSlaying in the Fall of Arthur's Kingdom.” Arthuriana 27, no. 2 (2017): 3-28. Battles, Dominique. Medieval Tradition of Thebes: History and Narrative in the OF Roman de Thèbes, Boccaccio, Chaucer, and Lydgate. New York: Routledge, 2004.

Beadle, Richard. “The York Cycle.” In The Cambridge Companion to Medieval English Theatre. Edited by Richard Beadle, 85-108. Cambridge: Cambridge University Press, 1994.

Beckwith, Sarah. "Ritual, Church, and Theatre: Medieval Drama of the Sacramental Body." In Culture and History 1350-1600: Essays on English Communities, Identities, and Writing. Edited by David Aers, 65-89. Detroit: Wayne State University Press, 1992. 
---. Signifying God: Social Relation and Symbolic Act in the York Corpus Christi Plays. Chicago: University of Chicago Press, 2001.

Bennett, H. S. The Pastons and Their England: Studies in an Age of Transition. Cambridge: Cambridge University Press, 1922.

Benson, C. David. "Civic Lydgate: The Poet and London.” In John Lydgate, Poetry, Culture, and Lancastrian England. Edited by Larry Scanlon and James Simpson, 147-168. Notre Dame: University of Notre Dame Press, 2006.

---. “Gawain's Defense of Lancelot in Malory's 'Death of Arthur'.” The Modern Language Review 78, no. 2 (1983): 267-72.

Blandeau, Agnès. “Les Liens Adelphiques Dans Quelques Textes du Moyen Age: ‘ce surgissement des violences au sein des alliances'." In Frères et sœurs: Les liens Adelphiques dans l'Occident Antique et Médiéval. Actes du colloque de Limoges, 21 et 22 septembre 2006. Edited by Sophie Cassagnes-Brouquet and Martine Yvernault, 229-236. Turnhout: Brepols, 2007.

Blench. J. W. Preaching in England in the Late Fifteenth and Sixteenth Centuries. Oxford: Basil Blackwell, 1964.

Bliss, Jane. Naming and Namelessness in Medieval Romance. Cambridge: D. S. Brewer, 2008

Boboc, Andreea. "Lay Performances of Work and Salvation in the York Cycle." Comparative Drama 43, no. 2 (2009): 247-71.

Bonfield, Lloyd and L. R. Poos. "The Development of the Deathbed Transfers in Medieval English Manor Courts.” In Medieval Society and the Manor Court. 
Edited by Zvi Razi and Richard Smith, 117-142. Oxford: Oxford University Press, 1996.

Boone, Blair W. "The Skill of Cain in the English Mystery Cycles." Comparative Drama 16, no. 2 (1982): 112-29.

Bowdon, Lynne. "Redefining Kinship: Exploring Boundaries of Relatedness in Late Medieval New Romney." Journal of Family History 29, no. 4 (2004): 407-420.

Bradbury, Nancy Mason. "Gamelyn.” In Heroes and Anti-Heroes in Medieval Romance. Edited by Neil Cartlidge, 129-44. Cambridge: D. S. Brewer, 2012.

Brandsma, Frank, Carolyne Larrington, and Corinne Saunders, eds, Emotions in Medieval Arthurian Literature: Body, Mind, Voice. Cambridge: D. S. Brewer, 2015.

Brantley, Jessica. "Middle English Drama Beyond the Cycle Plays." Literature Compass 10, no. 4 (2013): 331-42.

Brewer, Derek. Studies in Medieval English Romances. Cambridge: D. S. Brewer, 1988. Briscoe, Marianne G. "Preaching and Medieval English Drama." In Contexts for Early English Drama. Edited by Marianne G. Briscoe and John C. Coldewey, 151-72. Bloomington and Indianapolis: Indiana University Press, 1989.

Brockman, Bennett A. "Cain and Abel in the Chester Creation: Narrative Tradition and Dramatic Potential.” Medievalia et Humanistica 5 (1974): 169-82.

Brod, Harry. The Making of Masculinities: The New Men's Studies. Boston: Allen and Unwin, 1987.

Bullough, D. A. "Early Medieval Social Groupings: The Terminology of Kinship." Past \& Present 45, no. 1 (1969): 3-18. 
Burger, Glenn D. "Book Review Essay: Towards a Premodern Affective Turn.” Postmedieval: A Journal of Medieval Cultural Studies 5 (2014): 102-14.

Burger, Glenn D. and Holly A. Crocker, eds. Medieval Affect, Feeling, and Emotion. Cambridge: Cambridge University Press, 2019.

Burnley, J. D. "Late Medieval Translation: Types and Reflections.” In The Medieval Translator: The Theory and Practice of Translation in the Middle Ages. Edited by Roger Ellis, 37-53. Cambridge: D. S. Brewer, 1989.

Burns, E. Jane. Arthurian Fictions: Reading the Vulgate Cycle. Columbus: Ohio State University, 1985.

Butterworth, Philip. "Substitution: Theatrical Sleight of Hand in Medieval Plays." European Medieval Drama 9 (2005): 209-230.

Bryon, John. “Abel's Blood and the Ongoing Cry for Vengeance.” The Catholic Biblical Quarterly 73 (2011): 743-56.

Carpenter, Christine. The Wars of the Roses: Politics and the Constitution in England, c.1437-1509. Cambridge: Cambridge University Press, 1997.

Carruthers, Leo. "The World Made Flesh: Preaching and Community from the Apostolic to the Late Middle Ages." In Speculum Sermons: Interdisciplinary Reflections on the Medieval Sermon. Edited by Georgiana Donavin, Cary J. Nererman, and Richard Utz, 3-27. Turnhout: Brepols Publishers, 2004.

Cherewatuk, Karen. Marriage, Adultery, and Inheritance in Malory's Morte Darthur. Cambridge: D. S. Brewer, 2006.

Clark, James. G. The Benedictines in the Middle Ages. Woodbridge: Boydell and Brewer, 2011. 
---. "Thomas Walsingham Reconsidered: Books and Learning at Late-Medieval St. Albans." Speculum 77, no. 3 (2002): 832-60.

Clifton, Nicole. "Sir Gawain's Death and Prophecy in Malory's Morte Darthur." Arthurian Literature 34 (2018): 52-68.

Clogan, Paul M. "Lydgate and the Roman Antique." Florilegium 11 (1992): 7-21.

---. "Visions of Thebes in Medieval Literature." In The Force of Vision. vol. 2. Edited by Earl Miner and Haga Toru. 144-51. Tokyo: University of Tokyo Press, 1995.

Clopper, Lawrence. Drama, Play and Game: English Festive Culture in the Medieval and Early Modern Period. Chicago: University of Chicago Press, 2001.

--- "English Dram: From Ungodly Ludi to Sacred Play." In The Cambridge Compantion to Medieval English Literature. Edited by David Wallace, 739-66. Cambridge: Cambridge University Press, 1999.

---. "The History of the Development of the Chester Cycle." Modern Philology 75 (1978): 219-46.

Cohen, Jeffrey Jerome. Medieval Identity Machines. Minneapolis: University of Minneapolis Press, 2003.

Cohen, Jeffrey Jerome and Bonnie Wheeler, eds. Becoming Male in the Middle Ages. New York: Garland, 1997.

Coletti, Theresa. "Theology and Politics in the Towneley Play of the Talents." Medievalia et Humanistica 9 (1979): 111-26.

Conlee, John. Introduction to Prose Merlin. Edited by John Conlee, 1-10. Kalamazoo: Medieval Institute Publications, TEAMS, 1998. 
Cooney, Helen, ed. Nation, Court and Culture: New Essays on Fifteenth-Century English Poetry. Dublin: Four Courts Press, 2001.

Cooper, Helen. "Counter-Romance: Civil Strife and Father-Killing in the Prose Romances." In The Long Fifteenth Century: Essays for Douglas Gray. Edited by Helen Cooper, S. Mapstone, and J. Fichte, 141-62. Oxford: Clarendon Press, 1997.

Copeland, Rita. Rhetoric, Hermeneutics, and Translation in the Middle Ages: Academic Traditions and Vernacular Texts. Cambridge: Cambridge University Press, 1991. Coss, Peter. The Origins of the English Gentry. Cambridge: Cambridge University Press, 2003.

Coulson-Grigsby, Carolyn. "Medieval drama." In Misconceptions about the Middle Ages, Edited by Stephen J. Harris, and Bryon L. Grigsby, 169-176. New York: Routledge, 2008.

Cowdery, Taylor. "Lydgate and the Surplus of History." ELH 85, no.3 (Fall 2018): 568598.

Craig, Hardin. English Religious Drama of the Middle Ages. Oxford: Clarendon Press, 1955.

Crane, Susan. Insular Romance: Politics, Faith, and Culture in Anglo-Norman and Middle English Literature. Berkeley: University of California Press, 1986.

Crassons, Kate. "The Challenges of Social Unity: The Last Judgment Pageant and Guild Relations in York." Journal of Medieval and Early Modern Studies 37 (2007): $305-34$ 
Crépin, André. "Le fratricide dans l'Angleterre du Haut Moyen Âge." In Frères et soeurs : les liens adelphiques dans l'Occident antique et médiéval: Actes du colloque de Limoges, 21 et 22 septembre 2006. Edited by S. Cassagnes-Brouquet and M. Yvernault, 183-9. Turnhout: Brepols Publishers, 2007.

Crocker, Holly A. "Medieval Affects Now.” Exemplaria. 29, no. 1 (2017): 82-98.

Dalrymple, Roger. “"Evele knowen ye Merlyne, jn certeyn": Henry Lovelich's Merlin.” In Medieval Insular Romance: Translation and Innovation. Edited by Judith Weiss, Jennifer Fellows, and Morgan Dickson, 155-167. Cambridge: D. S. Brewer, 2000.

Davidoff, Leonore. Thicker than Water: Siblings and their Relations 1870-1920. Oxford: Oxford University Press, 2012.

Davidson, Clifford. "Violence and the Saint Play." Studies in Philology 98, no. 3 (2001): 292-314.

---. "Suffering in the York Plays." Philological Quarterly 81 (2002): 1-31.

Davies, Rees. "Kinsmen, Neighbours and Communities in Wales and the Western British Isles, c.1100 - c.1400." In Law, Laity and Solidarities: Essays in Honour of Susan Reynolds. Edited by Pauline Stafford, Janet L. Nelson, and Jane Martindale, 172187. Manchester: Manchester University Press, 2001.

Davis, Isabel. Writing Masculinity in the Later Middle Ages. Cambridge: Cambridge University Press, 2007.

Dean, Christophe. A Study of Merlin in English Literature from the Middle Ages to the Present: The Devil's Son. Lewiston: Edwin Mellen Press, 1992. 
Diller, Hans-Jürgen. "Laughter in Medieval English Drama: A Critique of Modernizing and Historical Analyses.” Comparative Drama 36, no. 1/2 (Spring/Summer 2002): 1-19.

---. “The Craftmanship of the Wakefield Master.” Anglia 83 (1965): 271-88.

Djordjević, Ivana. “Mapping Medieval Translation.” In Medieval Insular Romance:

Translation and Innovation. Edited by Judith Weiss, Jennifer Fellows, and Morgan Dickson, 7-24, Cambridge: D. S. Brewer, 2000.

Dobson, R. B. "Craft Guilds and the City: The Historical Origins of the York Mystery Plays Reconsidered.” In The Stage as Mirror: Civic Theatre in Late Medieval Europe. Edited by Alan E. Knight, 91-106. Woodbridge: Brewer, 1997.

Dunlop, Fiona S. "The Rule of Youth and the Rule of the Familia in Henry Medwall's Nature." In The Medieval Household in Christian Europe c. 850 - c. 1550: Managing Power, Wealth, and the Body. Edited by Cordelia Beattie, Cordelia, Anna Maslakovic, and Sarah Rees Jones, 155-166. Turnhout: Brepols, 2003. International Medieval Research 12.

Dunn, E. Catherine. "Popular Devotion in the Vernacular Drama of Medieval England." Medievalia et Humanistica 4 (1973): 55-68.

Ebin, Lois A. John Lydgate. Boston: Twayne Publishers, 1985.

Eckert, Kenneth. “'He Clothed Him and Fedde Him Evell': Narrative and Thematic 'Vulnerability' in Gamelyn." Medieval and Early Modern English Studies (Korea) 23, no. 1 (2015): 131-46.

Edwards, A. S. G. “Lydgate's Use of Chaucer: Structure, Strategy, and Style.” Revista Canaria de Estudios Ingleses 10 (1985): 175-82. 
Ehrstine, Glenn. "Framing the Passion: Mansion Staging as a Visual Mnemonic." In Visualizing Medieval Performance: Perspectives, Histories, Contexts. Edited by Elina Gertsman, 263-277. Aldershot: Ashgate, 2008.

Enders, Jody. The Medieval Theater of Cruelty: Rhetoric, Memory, Violence. Ithaca and New York: Cornell University Press, 2002.

Farvolden, Pamela. “'Love Can No Frenship': Erotic Triangles in Chaucer’s 'Knight's Tale' and Lydgate's Fabula Duorum Mercatorum." In Sovereign Lady: Essays on Women in Middle English Literature. Edited by Muriel Whitaker, 21-44. New York and London: Garland Publishing, 1995.

Faulkner, Mark and W. H. E. Sweet. "The Autograph Hand of John Lydgate and a Manuscript from Bury St. Edmunds Abbey.”Speculum 87, no. 3 (July 2012): 766-92.

Ferster, Judith. Fictions of Advice: The Literature and Politics of Counsel in Late Medieval England. Philadelphia: University of Pennsylvania Press, 1996.

Fewer, Colin. “The 'Fygure' of the Market: The N-Town Cycle and East Anglian Lay Piety." Philological Quarterly 77, no. 2 (March 1998): 117-47.

Field, P. J. C. “The Source of Malory's Tale of Sir Gareth.” In Malory, Texts and Sources, 246-60. Cambridge, D. S. Brewer, 1998.

---. The Life and Times of Sir Thomas Malory. Cambridge: D. S. Brewer, 1993.

Field, Rosalind. Traditions and Transformations in Medieval Romance. Cambridge: D. S. Brewer, 1999. 
Finotello, Ambra. "Transformations of the Merlin Legend in Late-Medieval England: Contextualizing Translation in 'of Arthour and of Merlin', Henry Lovelich's 'Merlin', and the 'Prose Merlin'." Ph.D Dissertation, Bangor University, 2014.

Finotti, Fabio. "Perspective and Stage Design, Fiction and Reality in the Italian Renaissance Theater of the Fifteenth Century.” Renaissance Drama n.s. 36-37 (2010): 21-42.

Fisher, Matthew. Scribal Authorship and the Writing of History in Medieval England. Columbus: Ohio State University Press, 2012.

Fitzmaurice, Susan M. The Familiar Letter in Early Modern English: A Pragmatic Approach. Amsterdam: John Benjamins, 2002.

Fleming, P. W. "The Lovelace Dispute: Concepts of Property and Inheritance in Fifteenth-Century Kent." Southern History 12 (1990): 1-18.

Fleming, Peter. "The Hautes and their 'Circle': Culture and the English Gentry." In England in the Fifteenth Century: Proceedings of the 1986 Harlaxton Symposium. Edited by Daniel Williams, 85-102. Woodbridge: The Boydell Press, 1987. ---. Family and Household in Medieval England. Houndmills: Palgrave Macmillan, 2001. Fletcher, Alan J. "The N-Town Plays." In The Cambridge Companion to Medieval English Theatre. Edited by Richard Beadle, 163-88. Cambridge: Cambridge University Press, 1994.

Forsyth, Dan W. "Sibling Rivalry, Aesthetic Sensibility, and Social Structure in Genesis.” Ethos 19, no. 4 (1991): 453-510. 
Frappier, Jean. “The Vulgate Cycle." In Arthurian Romances in the Middle Ages: A Collaborative History. Edited by Roger Sherman Loomis, 295-318. London: Oxford University Press, 1959.

French, Henry and Mark Rothery. "Male Anxiety Among Younger Sons of the English Landed Gentry, 1700-1900.” The Historical Journal 62, no. 4 (2019): 967-95.

Fry, Timothy. "The Unity of the Ludus Coentriae.” Studies in Philology 48 (1951): 52770.

Furnish, Shearle. "Labors of Love and the Work of Art: Divine Creativity and Human Artists in the Wakefield Noah." Medievalia et Humanistica 29 (2003): 71-80.

Gardner, John. The Construction of the Wakefield Cycle. Carbondale and Edwardsville: Southern Illinois University Press, 1974.

---. "Theme and Imagery in the Wakefield Mactacio Abel." PMLA 80 (September 1965): $515-21$.

Gayk, Shannon. "Images of Pity: The Regulatory Aesthetics of John Lydgate's Religious Lyrics." Studies in the Age of Chaucer 28 (2006): 175-203.

Gayley, Charles Mills. Plays of Our Forefathers and Some of the Traditions Upon Which They Were Founded. New York: Biblo and Tannen, 1907, rpt. 1968.

Gibson, Gail McMurray. “Manuscript as Sacred Object: Robert Hegge's N-Town Plays." The Journal of Medieval and Early Modern Studies 44, no. 3 (2014): 503529.

---. The Theatre of Devotion: East Anglian Drama and Society in the Late Middle Ages. Chicago: University of Chicago Press, 1989. 
---. "Bury St. Edmunds, Lydgate, and the N-Town Plays." Research Opportunities in Renaissance Drama 56 (1981): 56-90.

Gillingham, John. The Wars of the Roses: Peace and Conflict in Fifteenth-Century

England. London: Weidenfeld and Nicolson, 1987.

Given-Wilson, Christopher J. "Richard II, Edward II, and the Lancastrian Inheritance.” English Historical Review 109, no. 432 (1994): 553-571

Goldberg, P. J. P. "Craft Guilds, the Corpus Christi Play and Civic Government." In The Government of Medieval York: Essays in Commemoration of the 1396 Royal Charter. Edited by Sarah Rees Jones, 141-63. York: University of York, 1997. Borthwick Studies in History 3.

Göller, Karl Heinz. "Arthurian Chivalry and War in the Fourteenth and Fifteenth Centuries: History and Fiction.” In Spätmittelalterliche Artusliteratur. Edited by Karl Heinz Göller, 53-68. Paderborn: F. Schöningh, 1984.

Granger, Penny. "Devotion to Drama: The N-Town Play and Religious Observance in Fifteenth-Century East Anglia." In Medieval East Anglia. Edited by Christopher Harper-Bill, 302-317. Woodbridge: Boydell Press, 2005.

---. "Monk Students from Norwich Cathedral Priory at Oxford and Cambridge, c. 1300 to 1530.” The English Historical Review 106, no. 420 (1991): 556-83.

Gransden, Antonia, ed. The Customary of the Benedictine Abbey of Eynsham in Oxfordshire. Siegburg, Germany: Respublica-Verlag Franz Schmitt, 1963.

Greatrex, Joan. "Benedictine Sermons: Preparation and Practice in the English Monastic Cathedral Cloisters." In Medieval Monastic Preaching. Edited by Carolyn A. Muessig, 255-78. Leiden; Boston; Koln: Brill, 1998. 
Greenberger, Chaya. "Cain and Able: (Mis) Managing Rejections and Unmet Expectations." Jewish Bible Quarterly 44, no. 2 (2016): 116-24.

Grimaldi Pizzorno, Patrizia. “Justice at Play or the Play of Justice.” Ludica 8 (2003 for 2002): $115-127$.

Grimm, Kevin T. "Fellowship and Envy: Structuring the Narrative of Malory's 'Tale of Sir Tristram'." Fifteenth-Century Studies 20 (1993): 77-98.

Grossi, Joseph. "Cloistered Lydgate, Commercial Scribe: British Library Harley 2255 Revisited." Medieval Studies 72 (2010): 313-61.

Guerin, Wilfred L. “"The Tale of Gareth': The Chivalric Flowering.” In Malory's Originality: A Critical Study of Le Morte Darthur. Edited by R. M. Lumiansky, 99-117. Baltimore: John Hopkins Press, 1964.

---. “The Tale of the Death of Arthur': Catastrophe and Resolution.” In Malory's Originality: A Critical Study of Le Morte Darthur. Edited by R. M. Lumiansky, 233-74. Baltimore: John Hopkins Press, 1964.

Guilfoyle, Cherrell. "The Staging of the First Murder in the Mystery Plays in England." In Iconographic and Comparative Studies in Medieval Drama. Edited by Clifford Davidson and John H. Stroupe, 42-51. Kalamazoo: Medieval Institute Publications, 1991.

Hamelius, Paul. "The Character of Cain in the Towneley Plays." Journal of Comparative Literature I (1903): 324-44.

Hanawalt, Barbara A. The Ties that Bound Peasant Families in Medieval England. Oxford: Oxford University Press, 1986. 
Hanham, Alison. The Celys and their World: An English Merchant Family of the Fifteenth Century. Cambridge: Cambridge University Press, 1985.

Hanks, D. Thomas, ed. The Social and Literary Context of Malory's Morte Darthur. Oxford: D. S. Brewer, 2000.

Hanrahan, Michael. "“A Straunge Succesour Sholde Take Youre Heritage": The Clerk's Tale and the Crisis of Ricardian Rule." Chaucer Review 35, no. 4 (2001): 335350.

Happé, Peter. Cyclic Form and the English Mystery Plays: A Comparative Study of the English Biblical Cycles and Their Continental and Iconographic Counterparts. Amsterdam and New York: Rodopi, 2004.

Harty, Kevin J. "The Unity and Structure of the Chester Mystery Cycle." In The Chester Mystery Cycle: A Casebook. Edited by Kevin J. Harty, 69-88. New York and London: Garland Publishing, 1993.

Harvey, Barbara F. Living and Dying in England, 1100-1540: The Monastic Experience. Oxford: Oxford University Press, 1993.

Haseldine, Julian. "The Monastic Culture of Friendship.” In The Culture of Medieval English Monasticism. Edited by James G. Clark, 177-202. Woodbridge: Boydell and Brewer, 2007.

---. "Monastic Friendship in Theory and in Action." In Friendship in the Middle Ages and Early Modern Age: Explorations of a Fundamental Ethical Discourse. Edited by Albrecht Classen and Marilyn Sandidge, 349-93. Berlin, New York: De Gruyter, 2011. 
Heale, Nicolas. “John Lydgate, Monk of Bury St. Edmunds, as a Spiritual Director.” In The Vocation of Service to God and Neighbour: Essays on the Interests, Involvements and Problems of Religious Communities and Their Members in Medieval Society. Edited by Joan Greatrex, 59-71. Turnhout: Brepols, 1998.

Helterman, Jeffrey. Symbolic Action in the Plays of the Wakefield Master. Athens, Georgia: University of Georgia Press, 1981.

Hicks, Michael. False, Fleeting Perjur'd Clarence: George, Duke of Clarence, 1449-78. Revised Edition. Bangor, Gwynedd: Headstart History, 2012.

---. The Wars of the Roses. New Haven: Yale University Press, 2010.

----. English Political Culture in the Fifteenth Century. London: Routledge, 2002.

----. "Descent, partition and extinction: the "Warwick inheritance"." Bulletin of the Institute of Historical Research 52, no. 126 (1979): 116-128.

----. "The Warwick inheritance -- springboard to the throne.” The Ricardian 6, no. 81 (1983): 174-181.

Hill-Vásquez, Heather. Sacred Players: The Politics of Response in the Middle English Religious Drama. Washington, DC: Catholic University of America Press, 2007. Hirsch, Brett and Wortham, Christopher, eds. This Earthly Stage: World and Stage in Late Medieval and Early Modern England. Turnhout: Brepols, 2010. Cursor Mundi 13.

Hodges, Kenneth. Forging Chivalric Communities in Malory's Le Morte Darthur. New York: Palgrave MacMillan, 2005. 
Holbrook, Sue Ellen. “To the Well: Malory's Sir Palomides on Ideals of Chivalric Reputation, Male Friendship, Romantic Love, Religious Conversation - and Loyalty." Arthuriana 23, no. 3 (2013): 72-97.

Hubble, Elizabeth. "Par Fiance Bien Tenir: Medieval Same-Sex Chosen Kinship and Sworn Brotherhood in the Roman de Thèbes." Medieval Feminist Forum 49, no. 1 (2013): 5-29.

Ierstel, Geert van. "The Twenty Ploughs of Sir John: The Tale of Gamelyn and the Implications of Acreage.” In People and texts: Relationships in Medieval Literature. Edited by Thea Summerfield and Keith Busby, 111-122. Amsterdam: Rodopi, 2007.

Ingham, Patricia Clare. Sovereign Fantasies: Arthurian Romance and the Making of Britain. Philadelphia: University of Pennsylvania Press, 2001.

---. "Masculine Military Unions: Brotherhood and Rivalry in The Avowing of King Arthur." Arthuriana 6, no. 4 (1996): 25-44.

Ittel, Angela and Aiden Sisler. Siblings in Adolescence: Emerging Individuals, Lasting Bonds. Hove, East Sussex: Psychology Press, Taylor \& Francis Group, 2015.

Jaeger, C. Stephen. Ennobling Love: In Search of a Lost Sensibility. Philadelphia: University of Pennsylvania Press, 1999.

James, Mervyn. "Ritual, Drama, and Social Body in the Late Medieval English Town." Past and Present 98 (1983): 3-29.

Jansen, Katherine L. "Preaching as Playwriting: a Semi-Dramatic Sermon of the Fifteenth Century." In Defenders and Critics of Franciscan Life: Essays in 
Honour of John V. Fleming. Edited by Michael F. Cusato and Guy Geltner, 237247. Leiden: Brill, 2009.

Jayatilaka, Rohini. "The Old English Benedictine Rule: Writing for Women and Men." Anglo-Saxon England 32 (2003): 147-187.

Jennequin, Marie. “La Moralité des Frères de Maintenant: Propositions Pour une Étude Dramaturgique." European Medieval Drama 8 (2004): 107-126.

Jennings, John M. “The Distribution of Landed Wealth in the Wills of London Merchants, 1400-1450.” Mediaeval Studies 39 (1977): 261-280

Johnson, Christopher H., and David Warren Sabean, eds. Sibling Relations and the Transformations of European Kinship, 1300-1900. New York: Berghahn Books, 2011.

Johnson, E. Joe. Once There Were Two Friends: Idealized Male Friendship in French Narrative from the Middle Ages through the Enlightenment. Birmingham, Alabama: Summa Publications, INC., 2003.

Johnston, Alexandra F. "The York Cycle and the Chester Cycle: What do the Records Tell Us?” In The Chester Mystery Cycle: A Casebook. Edited by Kevin J. Harty. New York and London: Garland Publishing, 1993. 18-35.

Johnston, Michael. Romance and Gentry in Late Medieval England. Oxford: Oxford University Press, 2014.

Kaeuper, Richard. “An Historian's Reading of The Tale of Gamelyn.” Medium Avum 52 (1983): 51-62.

Karkov, Catherine E. “Adam and Eve on Muiredach's Cross: Presence, Absence and Audience." In From the Isles of the North: Early Medieval Art in Ireland and 
Britain. Proceedings of the Third International Conference on Insular Art held in the Ulster Museum, Belfast, 7-11 April 1994. Edited by Cormac Bourke, 205-211. Belfast: HMSO, 1995.

Karras, Ruth Mazo. Sexuality in Medieval Europe: Doing Unto Others. London: Routledge, 2005.

---. From Boys to Men: Formations of Masculinity in Late Medieval Europe. Philadelphia: University of Pennsylvania Press, 2003.

Kato, Tomomi, ed. A Concordance to the Works of Sir Thomas Malory. Tokyo: University of Tokyo Press, 1974.

Keen, Maurice. The Outlaws of Medieval Legend. London and New York: Routledge, 2001.

---. Nobles, Knights, and Men-at-Arms in the Middle Ages. London: University of Tokyo Press, 1996.

---. "Brotherhood in Arms." History 47, no. 158 (1962):1-17.

Kelly, Robert L. "Malory's 'Tale of King Arthur' and the Political Geography of Fifteenth-Century England." In Re-Viewing Le Morte Darthur: Texts and Contexts, Characters and Themes. Edited by Raluca Radulescu and K. S. Whetter, 79-93. Rochester, NY: D. S. Brewer, 2005. Arthurian Studies 60.

---. “Malory’s ‘Tale of Balin’ Reconsidered.” Speculum 54, no. 1 (1979): 85-99.

Kendall, M. The Yorkist Age: Daily Life During the Wars of the Roses. London: George Allen and Unwin, 1962.

Kennedy, Beverly. Knighthood in the Morte Darthur. Cambridge: D. S. Brewer, 1985. 
Kennedy, Edward Donald. “Sir Thomas Malory’s (French) Romance and (English) Chronicle.” In Arthurian Studies in Honour of P.J.C. Field. Edited by Bonnie Wheeler, 223-34. Rochester; Woodbridge: D. S. Brewer, 2004.

Kermode, Jennifer. "Sentiment and Survival: Family and Friends in Late Medieval English ‘Towns'.” Journal of Family History 24 (1999): 5-18.

King, Pamela M. "Poetics and Beyond: Noisy Bodies and Aural Variations in Medieval English Outdoor Performance.” In The Best Pairt of Our Play: Essays Presented to John J. McGavin. Part Two. Edited by Sarah Carpenter, Pamela M. King, Meg Twycross, and Greg Walker, 129-144. Cambridge: D. S. Brewer, 2017.

---. "The York Plays and the Feast of the Corpus Christi," Medieval English Theatre 22 (2000): 13-32.

Kline, Daniel T. "Father Chaucer and the Siege of Thebes: Literary Paternity, Aggressive Deference, and the Prologue to Lydgate's Oedipal Canterbury Tale.” Chaucer Review 34 (1999-2000): 217-35.

Knight, Stephen. "The Social Function of the Middle English Romances.” In Medieval Literature: Criticism, Ideology and History. Edited by David Aers, 99-112. New York: St. Martin's Press, 1986.

Kolve, V. A. The Play Called Corpus Christi. Stanford: Stanford University Press, 1966. Kuehn, Thomas. “A Late Medieval Conflict of Laws: Inheritance by Illegitimates in Ius Commune and Ius Proprium.” Law and History Review 15, no. 2 (1997): 243-273. La Farge, Catherine. “Blood and Love in Malory's Morte Darthur.” In A Companion to Medieval English Literature and Culture c. 1350-1500. Edited by Peter Brown, 634-47. Oxford: John Wiley \& Sons, Incorporated, 2007. 
Lander, J. R. Conflict and Stability in Fifteenth-Century England. $3^{\text {rd }}$ Edition. London: Hutchinson \& Co Ltd, 1969, 1977.

Lanzendorfer, Judith. "Folklore motifs and diminishing narrative time as a method of coherence in Malory's Morte Darthur." In Romance and Rhetoric: Essays in Honour of Dhira B. Mahoney. Edited by Georgiana Donavin and Anita Obermeier, 235-248. Turnhout: Brepols, 2010.

Larrington, Carolyn. Brothers and Sisters in Medieval European Literature. Woodbridge: York Medieval Press, 2015.

---. "Sibling Relations in Malory's Morte Darthur." Arthurian Literature 27 (2011): 5774.

---. "Some Recent Developments in the Psychology of Emotion and their Relevance to the Study of the Medieval Period.” Early Medieval Europe 10 (2001): 251-6.

Lawton, David. "Sacrilege and Theatricality: the Croxton Play of the Sacrament." Journal of Medieval and Early Modern Studies 33, no. 2 (2003): 281-309.

---. "Dullness and the Fifteenth Century.” ELH 54 (1987): 761-99.

Leclercq, Jean. The Love of Learning and the Desire for God: A Study of Monastic Culture. Translated by Catharine Misrahi. New York: Fordham University Press, 1961.

Leher, Seth. Chaucer and His Reader: Imagining the Author in Late Medieval England. Princeton: Princeton University Press, 1993.

----. “'Representyd Now in Yower Syght': The Culture of Spectatorship in LateFifteenth-Century England.” In Bodies and Disciplines: Intersections of Literature and History in Fifteenth-Century England. Edited by Barbara A. 
Hanawalt and David Wallace, 29-62. Minneapolis: University of Minnesota Press, 1996.

Leitch, Megan. "Malory in Literary Context." In A New Companion to Malory. Edited by Megan G. Leitch and Cory Rushton, 79-95. Cambridge: D. S. Brewer, 2019.

---. Romancing Treason: The Literature of the Wars of the Roses. Oxford: Oxford University Press, 2015.

---.“'Of his Ffader Spak he No Thing': Family Resemblance and Anxiety of Influence in Fifteenth-Century Prose Romance.” In Medieval into Renaissance: Essays for Helen Cooper. Edited by Andrew King and Matthew Woodcock, 55-72. Cambridge: D. S. Brewer, 2016.

---. 'L'amitié dans les Lettres au Moyen Âge: Autour d'un Manuscrit de la Bibliothèque de Petrarque." Revue du Moyen Âge Latin 1 (1945): 391-410.

Liddy, Lisa. “Affective bequests: creating emotion in York wills, 1400-1600.” In Understanding Emotions in Early Europe. Edited by Michael Champion and Andrew Lynch, 273-89. Turnhout: Brepols, 2015.

Liliequist, Jonas, ed. A History of Emotions, 1200-1800. London and Brookfield, Vermond: Pickering \& Chatto, 2012.

Lipton, Emma. "Space and the Culture of Witnessing in the York Entry into Jerusalem.” Journal of Medieval and Early Modern Studies 49, no. 2 (2019): 295317. 
----. "Witnessing and Legal Affect in the York Trial Plays." In Medieval Affect, Feeling, and Emotion." Edited by Glenn D. Burger and Holly A Crocker, 158-80. Cambridge: Cambridge University Press, 2019.

Lohmann, Meisha. “'On the Pavement, Thinking About the Government': The Corpus Christi Cycle and the Emergence of Municipal Merchant Power in York.” Mediaevalia 32 (2012 for 2011): 123-154.

Ludwikowska, Joanna. “(Breaking) The Law: Social Control, Self-Help and Violence in The Tale of Gamelyn." Studia Anglica Posnaniensia 48, no. 4 (2013): 63-77.

Lutter, Christine. "Preachers, Saints and Sinners: Emotional Repertoires in High Medieval Religious Role Models.” In A History of Emotions, 1200-1800. Edited by Jonas Liliequist, 49-63. London: Pickering \& Chatto, 2012.

Lynch, Andrew. “'With Face Pale': Melancholy Violence in John Lydgate's Troy and Thebes." In Representing War and Violence 1250-1600. Edited by Joanna Bellis and Laura Slater, 79-94. Woodbridge: Boydell Press, 2016.

---. "Peace is Good After War': The Narrative Seasons of English Arthurian Tradition." In Writing War: Medieval Literary Responses to Warfare. Edited by Corinne Saunders, Françoise Le Saux, and Neil Thomas, 127-146. Cambridge: D. S. Brewer, 2004.

Maclean, Sally-Beth. "The Southwest Entertains: Exeter and Local Performance Patronage." In Bring Furth the Pagants: Essays in Early English Drama Presented to Alexandra F. Johnston. Edited by David N. Klausner and Karen Sawyer Marsalek, 58-76. Toronto: University of Toronto Press, 2007. 
Maddern, Philippa C. Violence and Social Order: East Anglia, 1422-1442. London: Clarendon Press, 1991.

---. "Friends of the Dead: Executors, Wills and Family Strategy in Fifteenth-Century Norfolk." In Rulers and Ruled in Late Medieval England: Essays Presented to Gerald Harriss. Edited by Rowena E. Archer and Simon Walker, 155-174. London: Hambledon, 1995.

Maddox, Donald and Sara Sturm-Maddox. "French Confraternity Drama of the Fourteenth Century: the Miracles de Nostre Dame par Personnages." In Parisian Confraternity Drama of the Fourteenth Century: The Miracles de Nostre Dame par Personnages. Edited by Donald Maddox and Sara Sturm-Maddox, 1-28. Turnhout: Brepols, 2008.

Mandel, Jerome. "The Idea of Family in Chrétien de Troyes and Sir Thomas Malory." Arthuriana 12, no. 4 (Winter 2002): 90-9.

Mann, Jill. “"Taking the Adventure': Malory and the Suite du Merlin.” In Life in Words: Essays on Chaucer, the Gawain-Poet, and Malory. Edited by Mark David Rasmussen, 243-274. Toronto: University of Toronto Press, 2014.

Mapstone, Sally. "Malory and the Scots.” Arthurian Literature 28 (2011): 107-20.

Mazel, Florian. “'Frères Ennemis'. Compétition Intra-familiale et Intervention Pontificale dans les Successions Princières à l'âge Grégorien (Espace Français).” In Coopétition: Rivaliser, coopérer dans les sociétés du haut Moyen Age (5001100). Edited by Régine Le Jan, Geneviève Bührer-Thierry, and Stefano Gasparri, 255-267. Turnhout: Brepols, 2018. Haut Moyen Age 31. 
McCarthy, Terence. "Malory and His Sources." In A Companion to Malory. Edited by Elizabeth Archibald and A. S. G. Edwards, 75-95. Cambridge: D. S. Brewer, 1996.

---. Reading the Morte Darthur. Cambridge: D. S. Brewer, 1988.

McClune, Kate. "Gawain.” In Heroes and Anti-Heroes in Medieval Romance. Edited by Neil Cartlidge, 115-28. Cambridge: D. S. Brewer, 2012.

---.“"The Vengeaunce of My Brethirne': Blood Ties in Malory's Morte Darthur.” Arthurian Literature 28 (2011): 89-106.

McFarlane, K. B. England in the Fifteenth Century. London: The Hambledon Press, 1981.

McGuire, Brian Patrick. Friendship and Community: The Monastic Experience, 3501250. Kalamazoo: Cistercian Publications, 1988. Cistercian Studies Series 95. McNamer, Sarah. Affective Meditation and the Invention of Medieval Compassion. Philadelphia: University of Pennsylvania Press, 2010.

Mead, William Edward. Introduction in Merlin, or the Early History of Arthur: A Prose Romance, EETS o.s. 112, V-CXL. London: K. Paul, Trench, Trübner \& Co., 1899.

Meale, Carol M. “'The Hoole Book': Editing and the Creation of Meaning in Malory's Text.” In A Companion to Malory. Edited by Elizabeth Archibald and A. S. G. Edwards, 3-17. Cambridge: D. S. Brewer, 1996.

---. "Manuscripts, Readers, and Patrons in Fifteenth-Century England: Sir Thomas Malory and Arthurian Romance." Arthurian Literature 4 (1985): 93-126. 
---. "The Manuscript and Early Audience of the Middle English Prose Merlin." In The Changing Face of Arthurian Romance: Essays on Arthurian Prose Romances in memory of Cedric B. Pickford. Edited by Alison Adams, Armel H. Diverres, Karen Stern, and Kenneth Varty, 92-122. Cambridge: Boydell Press, 1986. Arthurian Studies 16.

Menuge, Noël James. Medieval Wardship in Romance and Law. Cambridge: D. S. Brewer, 2001.

Meredith, Peter. "The Towneley Cycle." In The Cambridge Companion to Middle English Theatre. Edited by Richard Beadle, 163-88. Cambridge: Cambridge University Press, 1994.

Meyer-Lee, Robert J. Poets and Power from Chaucer to Wyatt. Cambridge: Cambridge University Press, 2007.

Mills, David. “The Chester Cycle.” In The Cambridge Companion to Middle English Theatre. Edited by Richard Beadle, 134-62. Cambridge: Cambridge University Press, 1994.

---. "Theories and Practices in the Editing of the Chester Cycle Play-manuscripts." In The Chester Mystery Cycle. Edited by Kevin J. Harty, 3-17. New York and London: Garland Publishing, 1993.

Mitchell, W. I., "Choosing the Avenger: Some Aspects of the Bloodfeud in Medieval Iceland and England." Law and History Review 1, no. 2 (1983): 159-204. Mitchell-Smith, Ilan. "Defining Violence in Middle English Romances: Sir Gowther and Libeaus Desconus." Fifteenth-Century Studies 34 (2009): 148-161. 
Morrison, Karl. F. Understanding Conversion. Charlottesville: University Press of Virginia, 1992.

Moss, Rachel. Fatherhood and its Representations in Middle English Texts. Cambridge: D. S. Brewer, 2013.

Mortimer, Nigel. Lydgate's “Fall of Princes”: Narrative Tragedy in Its Literary and Political Contexts. Oxford: Clarendon Press; New York: Oxford University Press, 2005.

Nall, Catherine. Reading and War in Fifteenth-Century England: From Lydgate to Malory. Cambridge: D. S. Brewer, 2012.

Naughton, Ryan. 'Peace, Justice and Retinue-Building in Malory's 'The Tale of Sir Gareth of Orkney'." Arthurian Literature 24 (2012): 143-60.

Nauta, Rein. "Cain and Abel: Violence, Shame and Jealousy.” Pastoral Psychology 58 (2009): 65-73.

Nelson, Alan H. The Medieval English Stage: Corpus Christi Pageants and Plays. Chicago and London: University of Chicago Press, 1974.

Newstead, Helaine. “Arthurian Legends." In A Manual of the Writings in Middle English: 1050-1500. Vol. 1. Edited by J. Burke Severs. Romances, 1967, 38-79. New Haven: The Connecticut Academy of Arts and Sciences, 1967-2005.

Nolan, Barbara. "The Tale of Sir Gareth and the Tale of Sir Lancelot." In A Companion to Malory. Edited by Elizabeth Archibald and A. S. G. Edwards, 153-181. Cambridge: D. S. Brewer, 1996.

Nolan, Maura. John Lydgate and the Making of Public Culture. Cambridge: Cambridge University Press, 2005. 
Normington, Katie. "Player Transformation: The Role of Clothing and Disguise." In Medieval Theatre Performance: Actors, Dancers, Automata and their Audiences, Edited by Philip Butterworth and Katie Normington, 76-92. Cambridge: D. S. Brewer, 2017.

Norris, Ralph. "Malory and His Sources." In The New Companion to Malory. Edited by Megan G. Leitch and Cory James Rushton, 32-52. Cambridge: D. S. Brewer, 2019.

---. “Another Source for Malory’s ‘Tale of Sir Gareth'.” Arthurian Literature 32 (2015): $59-74$.

---. Malory's Library: The Sources of the Morte Darthur. Cambridge: D. S. Brewer, 2008. Owst, G. R. Preaching in Medieval England: An Introduction to Sermon Manuscripts of the Period, c. 1350-1450. New York: Russell \& Russell, 1965.

Patterson, Lee. "Making Identities in Fifteenth-Century England: Henry V and John Lydgate." In New Historical Literary Studies: Essays on Reproducing Texts, Representing History. Edited by Jeffrey N. Cox and Larry J. Reynolds, 69-107. Princeton: Princeton New Jersey, 1993.

Payling, Simon J. “Murder, Motive and Punishment in Fifteenth-Century England: Two Gentry Case-Studies.” English Historical Review 113, no. 450 (1998): 1-17.

Pearsall, Derek. John Lydgate. London: Routledge \& Kegan Paul, 1970.

---. "Chaucer and Lydgate." In Chaucer Traditions: Studies in Honour of Derek Brewer. Edited by Ruth Morse and Barry Windeatt, 39-53. Cambridge: Cambridge University Press, 1990.

---. “Lydgate as Innovator.” Modern Language Quarterly 53 (1992): 5-22. 
Pettitt, Tom. "Performing Intrusions: Interaction and Interaxionality in Medieval English Theatre." In Medieval Theatre Performance: Actors, Dancers, Automata and their Audiences. Edited by Philip Butterworth and Katie Normington, 52-75. Cambridge: D. S. Brewer, 2017.

Purdy, Rob Roy. “The Friendship Motif in Middle English Literature.” in Vanderbilt Studies in the Humanities. Vol. 1. Edited by Richmond C. Beatty, et al, 113-41. Nashville: Vanderbilt University Press, 1951.

Puzicha, Michaela. "The 'Fathers' in the Benedictine Rule: Appeals to the Ideal and the Critical Community." American Benedictine Review 61, no. 1 (2010): 18-29.

Radulescu, Raluca L. Romance and its Contexts in Fifteenth-Century England: Politics, Piety and Penitence. Cambridge: D. S. Brewer, 2013.

---. The Gentry Context for Malory’s 'Morte Darthur'. Cambridge: D. S. Brewer, 2003. Arthurian Studies 55.

---. "'Talkyng of Cronycles of Kinges and of Other Polycyez': Fifteenth-Century Miscellanies, the Brut and the Readership of Le Morte Darthur." Arthurian Literature 18 (2001):125-141.

Ramey, Lynn. "Medieval Miscegenation: Hybridity and the Anxiety of Inheritance." In Contextualizing the Muslim Other in Medieval Christian Discourse. Edited by Jerold C. Frakes, 1-19. New York: Palgrave Macmillan, 2011.

Ramey, Peter. "The Audience-Interactive Games of Middle English religious Drama.” Comparative Drama 47, no. 1 (2013): 55-83.

Ransom, James Fitzhugh. “A Study of Henry Lovelich’s Merlin.” PhD. Dissertation, Stanford University, 1962. 
Razi, Zvi. "The Erosion of the Family-Bond in the Late Fourteenth and Fifteenth Centuries: A Methodological Note.” In Land, Kinship and Life-Cycle. Edited by Richard M. Smith, 295-304. Cambridge: Cambridge University Press, 1984.

Reddy, William M. The Navigation of Feeling: A Framework for the History of Emotions. Cambridge: Cambridge University Press, 2001.

Renoir, Alain. The Poetry of John Lydgate. Cambridge, MA: Harvard University Press, 1967.

Renoir, Alain and C. David Benson. A Manual of the Writings in Middle English, 10501500. Vol. 6. Edited by Albert E. Hartung. New Haven: The Connecticut Academy of Arts and Sciences, 1980.

Richardson, Malcolm. Middle-Class Writing in Late Medieval London. London: Pickering \& Chatto, 2011.

Richmond, Colin. The Paston Family in the Fifteenth Century: The First Phase. Cambridge: Cambridge University Press, 1990.

Riddy, Felicity. "Contextualizing Le Morte Darthur: Empire and Civil War." In $A$ Companion to Malory. Edited by Elizabeth Archibald and A. S. G. Edwards, 5574. Cambridge: D. S. Brewer, 1996.

---. "Reading for England: Arthurian Literature and National Consciousness." Bibliographical Bulletin of the International Arthurian Society 53 (1991): 314-32.

Ritch, K. Janet. "The Role of the Presenter in Medieval Drama." In 'Bring Furth the Pagants': Essays in Early English Drama Presented to Alexandra F. Johnston. Edited by David N. Klausner and Karen Sawyer Marsalek, 230-268. Toronto: University of Toronto Press, 2007. Studies in Early English Drama 9. 
Ritson, Joseph. Bibliographia Poetica. London: C. Roworth, 1802.

Riyeff, Jacob. “'Tynlvmyne': The Laetabundus: John Lydgate as Benedictine Poet.” JEGP 115, no. 3 (July 2016): 370-93.

Roach, Levi. Ethelred the Unready. New Haven and London: Yale University Press, 2016.

Robinson, J. W. Studies in Fifteenth-Century Stagecraft. Kalamazoo: Medieval Institute Publications, 1991.

Rosenberg, Samuel N. "The Prose Merlin and the Suite Du Merlin." In The Romance of Arthur, II. Edited by James J. Wilhelm, 213-66. New York: Garland, 1986.

Rosenthal, Joel T. Patriarchy and Families of Privilege in Fifteenth-Century England. Philadelphia: University of Pennsylvania Press, 1991.

---. "Lancastrian Episcopal Wills: Directing and Distributing." Medieval Prosopography 11, no. 1 (1990): 35-84.

“A Handlist of Aristocratic Wills, 1335-1530.” Family History 9 (1975): 23-59.

Rosenwein, Barbara. Emotional Communities in the Early Middle Ages. Ithaca, NY: Cornell University Press, 2006.

---. Generations of Feeling: A History of Emotions, 600-1700. Cambridge: Cambridge University Press, 2016.

---. "Theories of Change in the History of Emotions." In A History of Emotions, 12001800. Edited by Jonas Liliequist, 7-20. London: Pickering \& Chatto, 2012.

Rowe, Joy. "The Medieval Hospitals of Bury St. Edmunds." Medical History 2, no. 4 (1958): 253-63. 
Rushton, Cory. “Absent Fathers, Unexpected Sons: Paternity in Malory's 'Morte Darthur'." Studies in Philology 101 (2004): 136-52.

Salisbury, Eve. "Lybeaus Desconus: Transformation, Adaptation, and the MonstrousFeminine." Arthuriana 24, no. 1 (Spring 2014): 66-85.

Sanders, Arnold. “Sir Gareth and the 'Unfair Unknown': Malory's Use of the Gawain Romances." Arthuriana 16, no. 1 (Spring, 2006): 34-46.

Sartre, Jean-Paul. The Emotions, Outline of a Theory. Translated by Bernard Frechtman. New York: Philosophical Library, 1948.

Saunders, Corrine. "Writing from the Heart: Malory's Le Morte Darthur." In Emotions in English Arthurian Romance. Edited by Frank Brandsma, Carolyne Larrington, and Corinne Saunders, 31-46. Cambridge: D. S. Brewer, 2015.

---. “'Greater Love hath no man': Friendship in Medieval Romance.” In Traditions and Innovations in the Study of Medieval English Literature: The Influence of Derek Brewer. Edited by C. Brewer and B. Windeatt, 128-34. Cambridge: Cambridge University Press, 2013.

Saurette, Marc. "Peter the Venerable and Secular Friendship." In Friendship in the Middle Ages and Early Modern Age: Explorations of a Fundamental Ethical Discourse. Edited by Albrecht Classen and Marilyn Sandidge, 281-308. Berlin, New York: De Gruyter, 2011.

Scattergood, V. J. Politics and Poetry in the Fifteenth Century. London: Blandford Press, 1971.

Scherb, Victor I. "Liturgy and Community in N-Town 'Passion Play I'." Comparative Drama 29, no. 4 (December 1, 1995): 478-492. 
Schirmer, Walter F. Schirmer. John Lydgate. Berkley and Los Angeles: University of California Press 1952.

Schmolke-Hasselmann, Beate. “The Round Table: Ideal, Fiction, Reality.” Arthurian Literature 2 (1982): 41-75.

Schofield, William Henry. Studies on the Libeaus Desconus. Boston: Ginn \& Co., 1895.

Sedgewick, Eve Kosofsky. Between Men: English Literature and Male Homosocial Desire. New York: Cornell University Press, 1985.

Serp, Claire. "Fratrie, Fraternité et Fratricide dans le Cycle Lancelot-Graal." In Frères et Sœures. Les Liens Adelphiques dans l'Occident Antique et Médiéval. Edited by Sophie Cassagnes-Brouquet and Martine Yvernault, 201-9. Turnhout: Brepols, 2007.

Sévère, Richard. “Malory’s 'Chivalric Cliques': Public and Private Felyshyp in the Arthurian Community.” Arthurian Literature 32 (2015): 105-122.

Shannon, Jr., Edgar R. “Medieaval Law in The Tale of Gamelyn.” Speculum 28 (1951): 458-64.

Sheehan, Michael M. "English wills and the records of the ecclesiastical and civil jurisdictions." Journal of Medieval History 14, no. 1 (1988): 3-12.

Sheingorn, Pamela. "The Moment of Resurrection in the Corpus Christi Plays." Medievalia et Humanistica 11 (1982): 111-29.

Simpson, James. Reform and Cultural Revolution. Oxford: Oxford University Press, 2002. 
---. “'Dysemol daies and fatal houres': Lydgate's Destruction of Thebes and Chaucer's Knight's Tale." In The Long Fifteenth-Century: Essays for Douglas Gray. Edited by Helen Cooper and Sally Mapstone, 15-33. Oxford: Clarendon Press, 1997.

Sminova, Victoria, Marie Anne Polo de Beaulieu, and Jacques Berloiz, "Introduction.” In The Art of Cistercian Persuasion in the Middle Ages and Beyond: Caesarius of Heisterbach's Dialogue on Miracles and Its Reception, 1-30. Boston: Brill, 2015.

Smith, Richard M. "Families and Their Land in an Area of Partible Inheritance: Redgrave, Suffolk 1260-1320.” In Land, Kinship and Life-cycle. Edited by Richard M. Smith, 135-195. Cambridge: Cambridge University Press, 1984.

Spearing, A. C. "Lydgate's Canterbury Tale: The Siege of Thebes and Fifteenth-Century Chaucerianism." In Fifteenth-Century Studies: Recent Essays. Edited by Robert F. Yeager, 333-364. Hamden: Archon, 1984.

Sponsler, Claire. “Lydgate and London's Public Culture.” In Lydgate Matters: Poetry and Material Culture in the Fifteenth Century. Edited by L. Cooper and A. Denny-Brown, 13-41. New York: Palgrave Macmillan, 2008.

---. "The Culture of the Spectator: Conformity and Resistance to Medieval Performances.” Theatre Journal 44, no. 1 (1992): 15-29.

Staples, Kate Kelsey Staples. Daughters of London: Inheriting Opportunity in the Late Middle Ages. Boston: Brill, 2011.

Stearns Peter N. and Carol Z Stearns. "Emotionology: Clarifying the History of Emotions and Emotional Standards.” The American Historical Review 90, no. 4 (1985): 813-36. 
Steenbrugge, Charlotte. Drama and Sermon in Late Medieval England: Performance, Authority, Devotion. Kalamazoo: Medieval Institute Publications, 2017.

---. "A quantitative and qualitative assessment of audience responses." European Medieval Drama 21 (2017): 67-83.

---. "Presenters in N-Town: 'We Asygne it to Zoure Good Deliberacion'." European Medieval Drama 16 (2012): 53-67.

Steiner, Emily. "William Langland." In The Cambridge Companion to Medieval Law. Edited by Candace Barrington and Sebastian Sobecki, 121-34. Cambridge: Cambridge University Press, 2019.

---. Documentary Culture and the Making of Medieval English Literature. Cambridge: Cambridge University Press, 2003.

Stern, Karen. "The Middle English Prose Merlin." In The Changing Face of Arthurian Romance: Essays on Arthurian Prose Romances in memory of Cedric B. Pickford. Edited by Alison Adams, Armel H. Diverres, Karen Stern, and Kenneth Varty. 112-122. Cambridge: Boydell Press, 1986. Arthurian Studies 16.

Stets, Jan E. "Future Directions in the Sociology of Emotions." Emotion Review 2, no. 3 (July 2010): 265-8.

Stevens, Martin. Four Middle English Mystery Cycles: Textual, Contextual, and Critical Interpretations. Princeton: Princeton University Press, 1987.

Straker, Scott-Morgan. "Deference and Difference: Lydgate, Chaucer, and the Siege of Thebes." Review of English Studies: A Quarterly Journal of English Literature and the English Language 52, no 205 (2001): 1-21. 
Street, Meagan. "Translation Anxiety: Tradition and Revision in a Middle English Romance." In Deviance-Textual Control: New Perspectives in Medieval Studies. Edited by Megan Cassidy, Helen Hickey, and Meagan Street, 121-138. Melbourne: University of Melbourne, 1997.

Stretter, Robert. "Rewriting Perfect Friendship in Chaucer's Knight's Tale and Lydgate's Fabula Duorum Mercatorum." Chaucer Review 37 (2003): 234-52.

Strietman, Elsa. “'Every Man, I Wyll Go With Thee and Be Thy Guide': Narrators, Expositors, and Prompters in the Drama of the Low Countries." In The Narrator, the Expositor, and the Prompter in European Medieval Theatre. Edited by Philip Butterworth, 11-44. Turnhout: Brepols, 2007. Medieval Texts and Cultures of Northern Europe 17.

Strohm, Paul. England's Empty Throne. New Haven: Yale University Press, 1999.

Struever, Nancy S. Theory as Practice: Ethical Inquiry in the Renaissance. Chicago: University of Chicago Press, 1992.

---. "Propaganda, Intentionality, and the Lancastrian Lydgate." In John Lydgate: Poetry, Culture, and Lancastrian England. Edited by Larry Scanlon and James Simpson, 98-128. Notre Dame: University of Notre Dame Press, 2006.

Sugano, Douglas. “"This Game Wel Pleyd in Good a-Ray': The N-Town Playbooks and East Anglian Games.” Comparative Drama 28, no. 2 (July 1, 1994): 221-234.

Talarico, Kathryn Marie. "Sounds of Silence: Rewriting, Rereading, and Retelling the Arthurian Legend." In Satura: Studies in Medieval Literature in Honour of Robert R. Raymo. Edited by Nancy M. Reale and Ruth E. Sternglantz, 48-73. Donington, England: Shaun Tyas, 2001. 
Thatcher, Tom. "Cain and Abel in Early Christian Memory: A Case Study in 'The Use of the Old Testament in the New'.” The Catholic Biblical Quarterly 72 (2010): 73251.

Travis, Peter W. Dramatic Design in the Chester Cycle. Chicago: University of Chicago Press, 1982.

Turner, Jonathan. "The Sociology of Emotions: Basic Theoretical Arguments.” Emotion Review 1, no. 4 (October 2009): 340-54.

Twycross, Meg. “The Theatricality of Medieval English Plays.” In The Cambridge Companion to Middle English Theatre. Edited by Richard Beadle, 37-84. Cambridge: Cambridge University Press, 1994.

Tydeman, William. “An Introduction to Medieval English Drama.” In The Cambridge Companion to Middle English Theatre. Edited by Richard Beadle, 1-36. Cambridge: Cambridge University Press, 1994.

Van Pelt, Nadia Thérèse. "Early English Spectatorship and the 'Cognitive Turn'.” In The Best Pairt of Our Play: Essays Presented to John J. McGavin. Part Two. Edited by Sarah Carpenter, Pamela M. King, Meg Twycross, and Greg Walker, 100-114. Cambridge: D. S. Brewer, 2017.

Velten, Hans Rudolf. "Devils On and Off Stage: Shifting Effects of Fear and Laughter in Late Medieval and Early Modern German Urban Theatre.” In Dramatic Experience: The Poetics of Drama and the Early Modern Public Sphere(s). Edited by Katja Gvozdeva, Tatiana Korneeva, and Kirill Ospovat, 250-268. Leiden: Brill, 2017. Drama and Theatre in Early Modern Europe 6. 
Wakelin, Daniel. Scribal Correction and Literary Craft: English Manuscripts 1375-1510. Cambridge: Cambridge University Press, 2014.

Wälde, Klaus and Agnes Moors. "Current Emotion Research in Economics." Emotion Review 9, no. 3 (July 2017): 271-8.

Walker, Greg. "Medieval Drama: The Corpus Christi in York and Croxton." In Readings in Medieval Texts: Interpreting Old and Middle English Literature. Edited by David Johnson and Elaine Treharne, 370-86. Oxford: Oxford University Press, 2005.

Ward, Renée. "Challenging the Boundaries of Medieval Romance: Thomas Chestre's Lybeaus Deconus." Florilegium 21 (2004): 119-34.

Warren, Michelle R. "Lydgate, Lovelich, and London Letters.” In Lydgate Matters: Poetry and Material Culture in the Fifteenth Century. Edited by Lisa H. Cooper and Andrea Denny-Brown, 113-38. New York: Palgrave Macmillan, 2008.

---. "Translation." In Middle English. Edited by Paul Strohm, 51-67. Oxford: Oxford University Press, 2007.

---. "Lydgate, Lovelich, and London Letters." In Lydgate Matters: Poetry and Material Culture in the Fifteenth Century. Edited by Lisa H. Cooper and Andrea DennyBrown. 113-38. New York: Palgrave Macmillan, 2008.

Watkins, John. "The Allegorical Theatre: Moralities, Interludes, and Protestant Drama." In The Cambridge Companion to Medieval English Literature. Edited by David Wallace, 767-92. Cambridge: Cambridge University Press, 1999. 
Watson, Nicolas. "The Politics of Middle English Writing." In The Idea of the Vernacular. Edited by Ian R. Johnson and Jocelyn Wogan-Browne, 331-52. University Park, PA: Pennsylvania State University Press, 1999.

Weddle, David L. Sacrifice in Judaism, Christianity, and Islam. New York: New York University Press, 2017.

Wheeler, Bonnie. "Romance and Parataxis and Malory: The Case of Sir Gawain's Reputation.” Arthurian Literature 12 (1993): 109-32.

Whetter, K. S. "Love and Death in Arthurian Romance." In The Arthurian Way of Death: The English Tradition. Edited by Karen Cherewatuk and K. S. Whetter, 94-114. Cambridge: D. S. Brewer, 2009.

---. Understanding Genre and Medieval Romance. Aldershot: Ashgate, 2008.

White, Naomi and Claire Hughes. Why Siblings Matter: The Role of Brother and Sister Relationships in Development and Well-Being. Oxon, NY: Routledge, 2019.

Wiehe, Roger. "Gawain, Lancelot and the Courtly Love Tradition in the Pre-Raphaelite Brotherhood and Tennyson." In Pre-Raphaelitism and Medievalism in the Arts. Edited by Liana De Girolami Cheney, 75-92. Lewiston: The Edwin Mellen Press, 1992.

Wierzbicka, Anna. "The 'History of Emotions' and the Future of Emotion Research." Emotion Review 2, no. 3 (July 2010): 269-73.

Wigram, Isolde. “The Warwick Inheritance.” The Ricardian 6, no. 83 (1983): 273.

Williams, Ann. Athelred the Unready: The Ill-Counselled King. London: Hambledon and London, 2003.

Wilson, Robert H. “The Fair Unknown in Malory.” PMLA 58 (1943): 1-21. 
Windeatt, Barry. "The Fifteenth-Century Arthur." In The Cambridge Companion to the Arthurian Legend. Edited by Elizabeth Archibald and Ad Putter, 84-102. Cambridge: Cambridge University Press, 2009.

Woolf, Rosemary. The English Mystery Plays. London: Routledge and Kegan Paul, 1972.

Workman, Samuel W. Fifteenth Century Translation as an Influence on English Prose. New York: Octagon Books, 1972.

Yoshimura, Christina. "The Experience and Communication of Envy Among Siblings, Siblings-in-Law, and Spouses.” Journal of Social and Personal Relationships 27, no. 8 (2010): 1075-88.

Zell, Michael L. "Fifteenth- and Sixteenth-Century Wills as Historical Sources." Archives 14, no. 2 (1979): 67-74.

Ziolkowski, Jan. M. “Twelfth-Century Understandings and Adaptations of Ancient Friendship." In Medieval Antiquity. Edited by Andries Welkenhuysen, Herman Braet, and Werner Verbeke, 59-81. Leuven: Leuven University Press, 1995. 